Prepared in coooperation with the New York State Department of Transportation

\title{
Magnitude and Frequency of Floods in New York
}

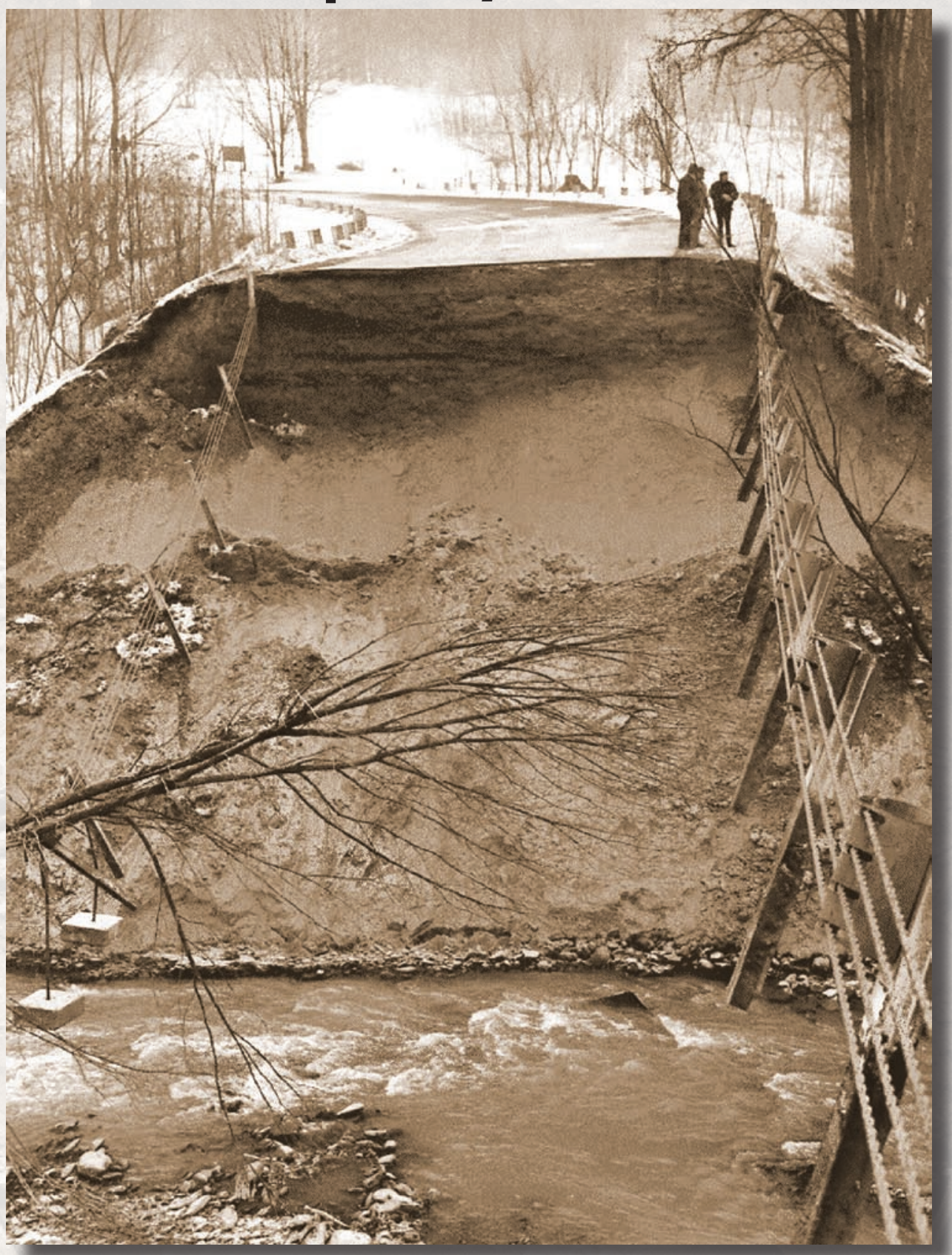

Scientific Investigations Report 2006-5112

U.S. Department of the Interior

U.S. Geological Survey 
Cover. Shows washout on Chase Brook Road, across Chase Brook near Cannonsville Reservoir in Delaware County, New York, January 19, 1996. (Photography courtesy of The Walton Reporter, January 24, 1996, page. 6) 


\section{Magnitude and Frequency of Floods in New York}

By Richard Lumia, Douglas A. Freehafer, and Martyn J. Smith

Prepared in cooperation with the New York State Department of Transportation

Scientific Investigations Report 2006-5112 


\section{U.S. Department of the Interior DIRK KEMPTHORNE, Secretary}

\section{U.S. Geological Survey \\ Mark D. Myers, Director}

\section{U.S. Geological Survey, Reston, Virginia: 2006}

For product and ordering information:

World Wide Web: http://www.usgs.gov/pubprod

Telephone: 1-888-ASK-USGS

For more information on the USGS--the Federal source for science about the Earth, its natural and living resources, natural hazards, and the environment:

World Wide Web: http://www.usgs.gov

Telephone: 1-888-ASK-USGS

Any use of trade, product, or firm names is for descriptive purposes only and does not imply endorsement by the U.S. Government.

Although this report is in the public domain, permission must be secured from the individual copyright owners to reproduce any copyrighted materials contained within this report.

Suggested citation:

Lumia, Richard, Freehafer, D.A., and Smith, M.J., 2006, Magnitude and frequency of floods in New York: U.S. Geological Survey Scientific Investigations Report 2006-5112, 152 p. 


\section{Preface}

This report includes a Geographic Information System (GIS) tool to compute basin characteristics used in the regional regression equations included with the report. It is the responsibility of the user to use the tool properly and to verify that the results are meaningful. The user is cautioned that although the tool has been tested, future uses might reveal errors that were not detected during testing. Users are encouraged to notify the U.S. Geological Survey New York Water Science Center of any errors found in the GIS tool by using the email address askny@usgs.gov. Updates might occasionally be made to the GIS tool. Users can check for updates on the Internet at URL http://ny.water.usgs.gov/projects/floodfreq/. 
This page has been left blank intentionally. 


\section{Contents}

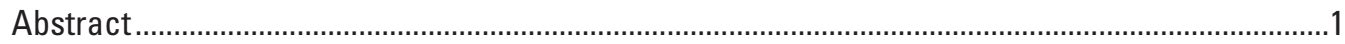

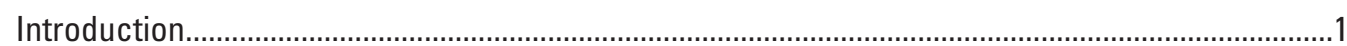

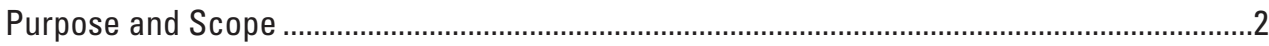

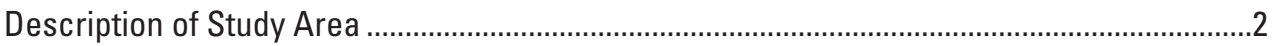

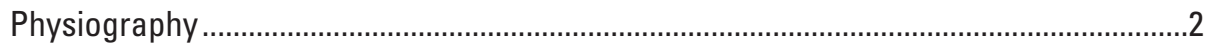

Geology

Climate

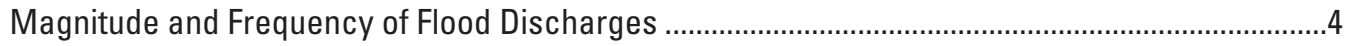

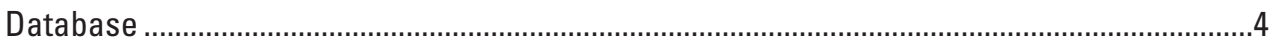

Annual Peak-Discharge Records..................................................................................

Magnitude and Frequency of Flood Discharges at Streamflow-Gaging Stations ...........9

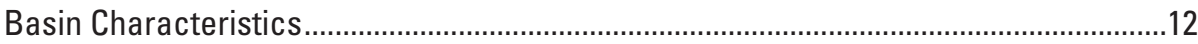

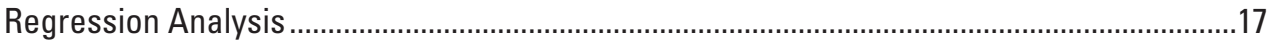

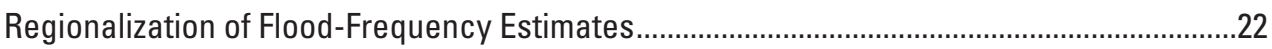

Delineation of Hydrologic Regions ..........................................................................22

Regional Basin and Peak-Discharge Characteristics ...................................................23

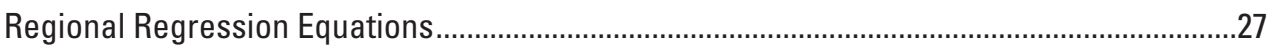

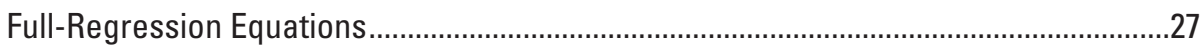

Drainage-Area-Only Equations ...............................................................................27

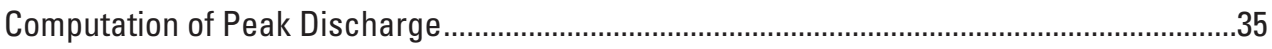

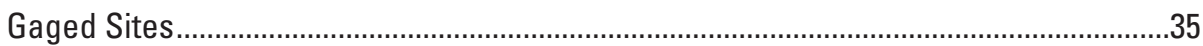

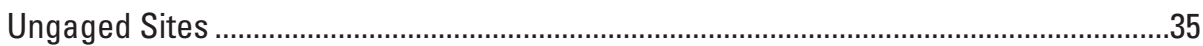

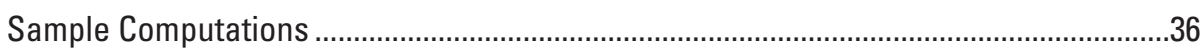

Limitations, Accuracy, and Sensitivity of Regression Equations ...................................................41

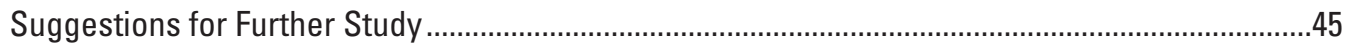

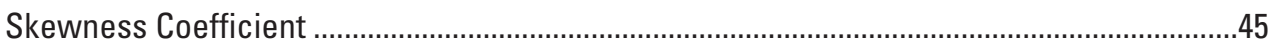

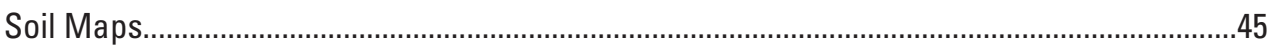

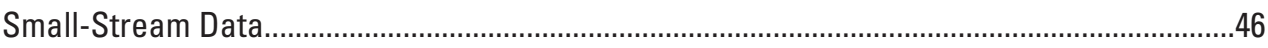

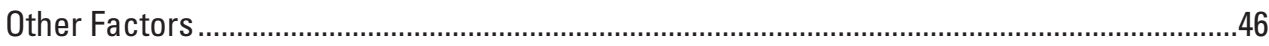

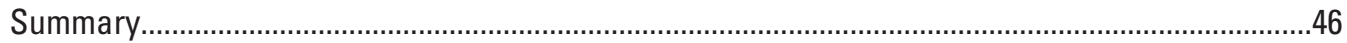

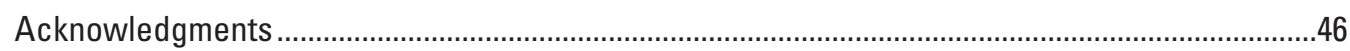

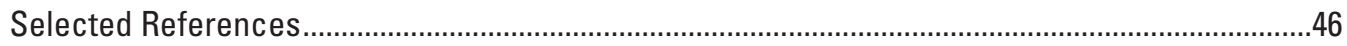

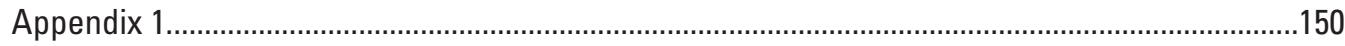

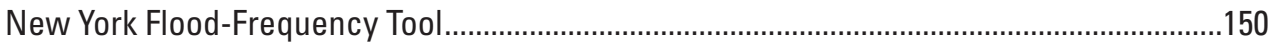

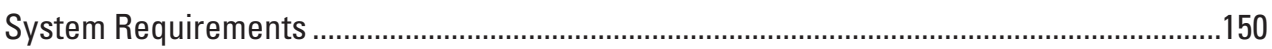

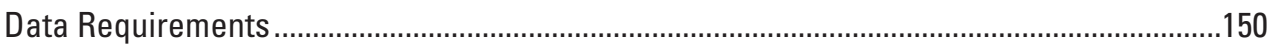

Installation of the New York Flood-Frequency Tool .........................................................150

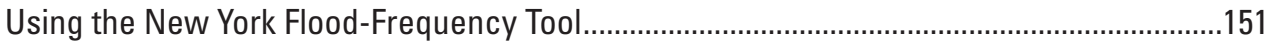

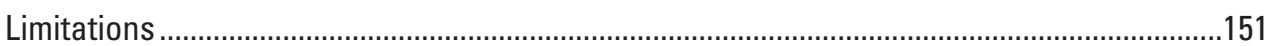

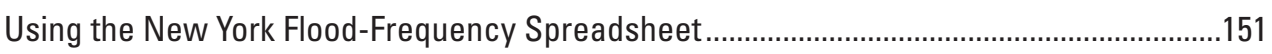

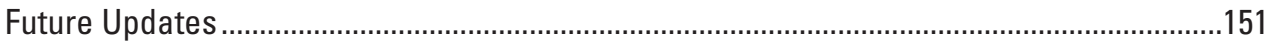




\section{DVD}

[in pocket]

\section{Figures}

1-2 Maps showing:

1. Physiographic provinces of New York, excluding Long Island 3

2. Six hydrologic regions of New York and locations of 388 streamflow-gaging stations represented in this study.

3-6 Graphs showing:

3. Annual peak discharges and 100 -year peak discharges for 388 rural, unregulated streamflow-gaging stations used in this study....

4. Annual peak discharges and trend line for streams in two highly developed areas $(A, B)$ and in an undeveloped area $(C)$ in New York: $(A) 01311000-$ Pines Brook at Malverne, $(B) 01302000$ - Bronx River at Bronxville, and (C) 01512500 - Chenango River near Chenango Forks

5. Annual peak discharges and trend lines for $(A)$ all study sites and $(B)$ all small stream (10- to 50-square miles) study sites

6. Examples of flood-frequency curves for selected streamflow-gaging stations along the Hudson River in New York

7. Locations of 122 streamflow-gaging stations on regulated and urbanized streams in New York

8-9 Graphs showing:

8. Annual peak discharges and moving 100- and 2-year flood discharges for two streamflow-gaging stations in New York: $(A) 01512500$ - Chenango River near Chenango Forks, and $(B) 04256000$ - Independence River at Donnattsburg...........14

9. Slopes of the lower half and upper half of the main channel for 388 streamflow-gaging stations used in the study.

10-14 Maps showing:

10. Areas in and adjacent to New York with elevations above 1,200 feet, as interpreted from 30-meter digital elevation model (DEM) data

11. Areas of urbanization, forest, and storage in and adjacent to New York, as interpreted from the National Land Cover Dataset (NLCD) land-use data

12. Mean annual runoff in areas in and adjacent to New York

13. Mean annual precipitation in areas in and adjacent to New York

14. Seasonal maximum snow depth (50th percentile) in areas in and adjacent to New York.

15-21 Graphs showing:

15. Boxplots of 50-year peak-discharge residuals from the statewide regression for streamflow-gaging stations within six hydrologic regions of New York, before and after regionalization.

16. Boxplots of selected basin characteristics for streamflow-gaging stations within six hydrologic regions of New York

17. Boxplots of selected peak-discharge characteristics for streamflow-gaging stations within six hydrologic regions of New York 
18. Distribution of streamflow-gaging stations within each of six hydrologic regions of New York and for all stations combined by $(A)$ length of record, and $(B)$ drainage-basin size

19. Monthly frequency of annual peak flows within each of six hydrologic regions of New York and for all streamflow-gaging stations combined for (A) all 388 study basins, and (B) 79 streams in small (less than 10-square miles) basins..

20. Average flood-frequency curves for six hydrologic regions of New York and for all 388 study sites combined

21. Maximum, minimum, and average flood-frequency curves for six hydrologic regions of New York and for all 388 study sites combined

\section{Tables}

1. Full-regression equations for estimating peak discharges for rural, unregulated streams in each of six hydrologic regions of New York, excluding Long Island.

2. Standard errors of prediction and equivalent years of record for full regression equations and drainage-area-only regression equations, for six hydrologic regions of New York, excluding Long Island

3. Regression equations based on drainage area only for estimating peak discharges for rural, unregulated streams in each of six hydrologic regions of New York, excluding Long Island

4. Minimum, maximum, and median values for basin characteristics used in the regression analyses for six hydrologic regions in New York, excluding Long Island .....43

5. Results of sensitivity analysis-percent change in computed 50-year peak discharges as a result of \pm 30 -percent change in selected variables within each of six hydrologic regions of New York, excluding Long Island

6. Selected statistics for skew coefficients for each of six hydrologic regions of New York, excluding Long Island.

7. Location, drainage area, period of record, and maximum known discharge and recurrence interval for rural, unregulated streams in New York, excluding Long Island

8. Peak discharge for 10 selected recurrence intervals on rural, unregulated streams in New York, excluding Long Island.

9. Location, drainage area, period of record, and calculated peak discharge for 10 recurrence intervals for regulated streams, and streams in urbanized basins in New York, including Long Island.....

10. Data on selected basin characteristics of rural, unregulated streams in New York, excluding Long Island 


\section{Conversion Factors, Datum and Acronyms}

\begin{tabular}{|c|c|c|}
\hline Multiply & By & To obtain \\
\hline \multicolumn{3}{|c|}{ Length } \\
\hline inch (in.) & 25.4 & millimeter $(\mathrm{mm})$ \\
\hline foot (ft) & 0.3048 & meter $(\mathrm{m})$ \\
\hline mile (mi) & 1.609 & kilometer $(\mathrm{km})$ \\
\hline \multicolumn{3}{|c|}{ Area } \\
\hline square mile $\left(\mathrm{mi}^{2}\right)$ & 2.590 & square kilometer $\left(\mathrm{km}^{2}\right)$ \\
\hline \multicolumn{3}{|c|}{ Volume } \\
\hline cubic foot $\left(\mathrm{ft}^{3}\right)$ & 0.02832 & cubic meter $\left(\mathrm{m}^{3}\right)$ \\
\hline \multicolumn{3}{|c|}{ Flow rate } \\
\hline cubic foot per second $\left(\mathrm{ft}^{3} / \mathrm{s}\right)$ & 0.02832 & cubic meter per second $\left(\mathrm{m}^{3} / \mathrm{s}\right)$ \\
\hline $\begin{array}{l}\text { cubic foot per second per square } \\
\text { mile }\left[\left(\mathrm{ft}^{3} / \mathrm{s}\right) / \mathrm{mi}^{2}\right]\end{array}$ & 0.01093 & $\begin{array}{l}\text { cubic meter per second per square } \\
\text { kilometer }\left[\left(\mathrm{m}^{3} / \mathrm{s}\right) / \mathrm{km}^{2}\right]\end{array}$ \\
\hline
\end{tabular}

Vertical coordinate information is referenced to the National Geodetic Vertical Datum of 1929 (NGVD 29).

Horizontal coordinate information is referenced to the North American Datum of 1927 (NAD 27).

\section{LIST OF ACRONYMS}

$\begin{array}{ll}\text { AML } & \text { Arc Macro language } \\ \text { DEM } & \text { Digital elevation model } \\ \text { ESRI } & \text { Environmental Systems Research Institute } \\ \text { GIS } & \text { Geographic Information System } \\ \text { GLS } & \text { Generalized least-squares } \\ \text { LSD } & \text { Least significant difference } \\ \text { MSE } & \text { Mean-square-error } \\ \text { NED } & \text { National Elevation Dataset } \\ \text { NLCD } & \text { National Land Cover Dataset } \\ \text { NRCC } & \text { Northeast Regional Climate Center } \\ \text { OLS } & \text { Ordinary least-squares } \\ \text { SAS } & \text { Statistical Analysis System } \\ \text { SIM } & \text { Simultaneous inference methods } \\ \text { STATGO } & \text { State Soil Geographic } \\ \text { USGS } & \text { U.S. Geological Survey } \\ \text { VIF } & \text { Variance inflation factor }\end{array}$




\title{
Magnitude and Frequency of Floods in New York
}

\author{
By Richard Lumia, Douglas A. Freehafer, and Martyn J. Smith
}

\section{Abstract}

Techniques are presented for estimating the magnitude and frequency of flood discharges on rural, unregulated streams in New York, excluding Long Island. Peak-dischargefrequency data and basin characteristics from 388 streamflowgaging stations in New York and adjacent states were used to develop multiple linear regression equations for flood discharges with recurrence intervals ranging from 1.25 to 500 years. A generalized least-squares (GLS) procedure was used to develop the regression equations. Separate sets of equations were developed for each of six hydrologic regions of New York; standard errors of prediction range from 14 to 43 percent. Statistically significant explanatory variables in the regression equations include drainage area, main-channel slope, percent basin storage, mean annual precipitation, percent forested area, a basin lag factor, a ratio of mainchannel slope to basin slope, mean annual runoff, maximum snow depth, and percentage of basin above 1,200 feet. Drainage areas for the 388 sites used in the analyses ranged from 0.41 to 4,773 square miles.

Methods of computing flood discharges from the regression equations differ, depending on whether the estimate is for a gaged or ungaged basin, and whether the basin crosses hydrologic-region or state boundaries. Examples of computations are included. Discharge-frequency estimates for an additional 122 streamflow-gaging stations with significant regulation or urbanization (including Long Island) are also included as at-site estimates.

Basin characteristics, log-Pearson Type III statistics, and regression and weighted estimates of the discharge-frequency relations are tabulated for the streamflow-gaging stations used in the regression analyses. Sensitivity analyses showed that mean-annual precipitation, drainage area, mean annual runoff, and maximum snow depth are the variables to which computed discharges are most sensitive in the regression equations.

Included with the report is a DVD that provides computation procedures and geographic information system spatial datasets to compute basin characteristics used in the regional regression equations and flood-frequency estimates at a specified location on a stream.

\section{Introduction}

Flood damage along flood plains is a constant concern for local and regional water-resource managers and planners. The effective management of flood-prone areas, and the design of structures along rivers and streams, require knowledge of the magnitude and frequency of floods. Several previous U.S. Geological Survey (USGS) reports provide techniques for estimating the magnitude and frequency of floods on rural, unregulated streams in New York by the index-flood method (Robison, 1961; Speer and Gamble, 1965; Tice, 1968; Wiitala, 1965), by ordinary least-squares (OLS) multipleregression techniques (Darmer, 1970, and Zembrzuski and Dunn, 1979), and by generalized least-squares (GLS) multiple-regression techniques (Lumia, 1991). An additional 12 years of annual peak discharge data, updated skews (Lumia and Baevsky, 2000) for computing station flood-frequency curves as outlined in U.S. Water Resources Council Bulletin 17B (1981), and revised data on basin characteristics used for multiple-regression analyses enable refinement of the techniques established previously.

Since the 1990s, the USGS, in cooperation with New York State Department of Transportation, has been obtaining additional years of peak discharge records and has refined its basin characteristics data through geographic information system (GIS) coverages and techniques. The improved databases provide a basis for estimation of the magnitude and frequency of floods at gaged or ungaged sites on rural, unregulated streams in New York, excluding Long Island. Procedures for estimating peak discharges with recurrence intervals of $1.25,1.5,2,5,10,25,50,100,200$, and 500 years depend on whether the stream is gaged or ungaged, and whether its drainage basin crosses hydrologic-region boundaries or state lines. In this study, which was also conducted in cooperation with the New York State Department of Transportation, regression equations for six hydrologic regions of New York (excluding Long Island) were developed from data collected through September 1999 at 388 gaged sites in and adjacent to New York.

Development of techniques for estimating peak discharges at ungaged locations on regulated streams, 
urbanized basins, and streams on Long Island was beyond the scope of this study. Peak discharges for ungaged urban areas can be estimated through techniques of Sauer and others (1983). Flood characteristics of gaged stream locations that are urbanized (including Long Island sites) or regulated are presented herein as 122 at-site estimates only (these sites were not used in the development of the regional regression equations).

\section{Purpose and Scope}

This report presents techniques for estimating the magnitude and frequency of floods on rural, unregulated streams within six hydrologic regions of New York at gaged sites, ungaged sites, and ungaged sites on gaged streams. The information presented herein supersedes previous USGS data and reports on estimation of flood magnitude and frequency on rural, unregulated streams in New York.

The report discusses the delineation of the six hydrologic regions through statistical and hydrologic analyses and presents sets of equations for each of the six regions. It also describes use of the equations and includes sample computations, as well as tables of selected flood and basin characteristics data and summaries of statistical analyses.

\section{Description of Study Area}

Physiographic and geologic characteristics of New York that may help explain variations in streamflow were considered in the analysis and in the delineation of hydrologicregion boundaries (discussed in a later section). These factors affect the timing and magnitude of flood response, although many were not directly included in the regression equations. The area addressed in this study encompasses all of New York, excluding Long Island, as well as areas of adjacent states near the New York border.

\section{Physiography}

New York (excluding Long Island) encompasses parts or all of seven physiographic provinces (fig. 1), which range from high relief in the Adirondack and Catskill Mountains to low relief along the Great Lakes, the St. Lawrence River Valley, and the Hudson and Mohawk River Valleys. In northern New York, the Adirondack Province covers about 10,000 $\mathrm{mi}^{2}$. The western half of the province and parts of the southern and northern margins are plateaulike. Lakes and ponds are abundant (about 2,000), especially in and near the mountains. The eastern half of the Adirondack Province is mountainous; some elevations exceed 5,000 ft above sea level (Fenneman, 1938). The St. Lawrence Valley of extreme northern New York is a smooth glacial plain with elevations dropping below $200 \mathrm{ft}$ along the St. Lawrence River. The Mohawk River Valley, just south of the Adirondack Province, drains parts of the southern AdirondackMountains to the Hudson River.
The two major physiographic divisions of western New York are the Central Lowlands and the Appalachian Plateau. The Central Lowlands in New York extend east from Lake Erie, north of the Finger Lakes Region adjacent to Lake Ontario, to just west of the Mohawk and St. Lawrence River Valleys and the Adirondack Mountains. South of Lake Ontario, the lowland plain abuts the northern escarpment of the Appalachian Plateau, and east of Lake Ontario the plain comes to an end against the Tug Hill Plateau. Drainage throughout the Central Lowlands is generally toward Lakes Erie and Ontario. The Appalachian Plateau extends throughout the southern part of western New York east to and including the Catskill Mountains and southern sections of the Mohawk River Basin. The Appalachian Plateau is characterized by hilly terrain; its highest elevations are in the Allegheny and Catskill Mountains.

Physiographic divisions in eastern and southeastern New York include the Valley and Ridge Province, the New England Province, and the Piedmont Province. The Valley and Ridge Province extends from the New Jersey border, north through the lower Hudson River Valley to the southern end of Lake Champlain. Longitudinal drainage is prominent in the Hudson-Champlain section of the province. The New England Province also extends from the New Jersey border northward, crossing the southern part of the Hudson River. It includes the Taconic Mountains, running along the southeastern border of New York north to just south of Lake Champlain. The Piedmont Province includes a small lowland area in southeastern New York just north of New Jersey.

\section{Geology}

Crystalline rocks dominate the Adirondack and New England Provinces but contain carbonate rocks in outcrop fringes (escarpments) along the northern and eastern edges of the Appalachian Plateau Province, in isolated areas of the St. Lawrence Valley, and in eastern New York. Shale, the most extensive bedrock unit, predominates in the Appalachian Plateau, western Central Lowland, the Mohawk Valley, and the Valley and Ridge Province. Sandstone dominates in the Piedmont, St. Lawrence Valley, and eastern Central Lowland Provinces.

Bedrock in New York is covered with glacial deposits of till and stratified drift of variable thickness. The till mantles the uplands and small tributary valleys and generally is found beneath stratified drift in the larger valleys. Stratified drift forms the floors of large valleys and flat plains or terraces where bedrock relief is low. The stratified drift includes clay, silt, sand, and meltwater deposits of sand and gravel. The sand and gravel deposits form the principal aquifer systems of New York. 


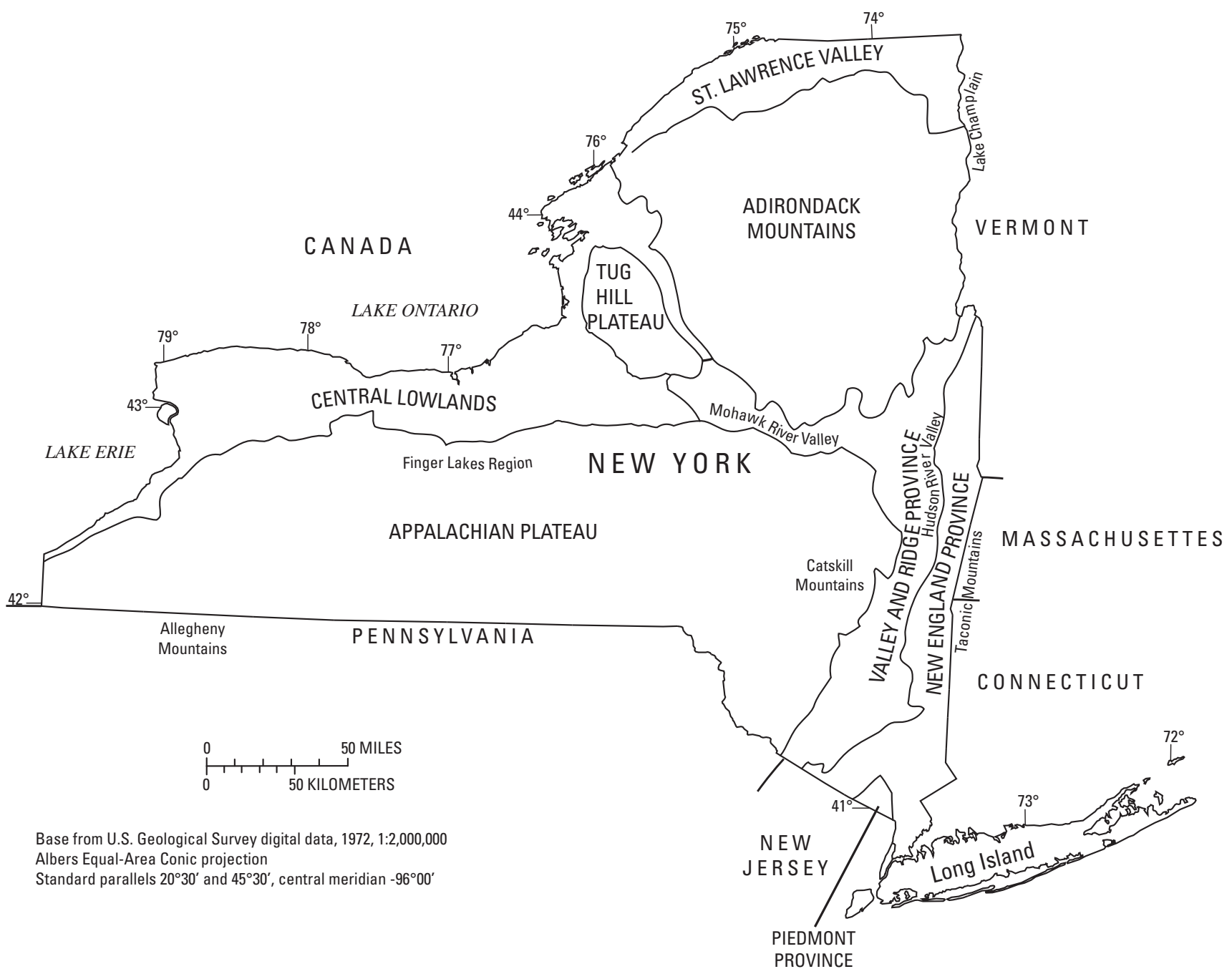

Figure 1. Physiographic provinces of New York, excluding Long Island (Modified from Lyford and others, 1984, figure 2).

\section{Climate}

The climate of New York is the humid continental type; cool, dry air masses move generally eastward through the state throughout the year, and warm, humid maritime tropical air masses from the south move northeastward during the summer. Mean annual precipitation ranges from almost 30 in. along Lakes Ontario and Champlain to about 60 in. in the southern Catskill Mountains.

The areal distribution of precipitation reflects the topographic relief and the general eastward-to-northeastward movement of storms. New York has a fairly uniform distribution of precipitation during the year and has no distinct rainy or dry season.

Regional differences in topography, elevation, and proximity to large bodies of water result in a wide variation of snowfall throughout the state. Maximum seasonal snowfall, averaging more than 175 in., occurs on the western and southwestern slopes of the Adirondack Moountains and Tug Hill Plateau (National Oceanic and Atmospheric
Administration, 1980). A secondary maximum of more than 150 in. prevails some 10 to $30 \mathrm{mi}$ inland from Lake Erie. The minimum seasonal snowfalls ( 25 to $35 \mathrm{in}$.) occur in extreme southeastern New York, and the minimum upstate snowfalls (40 to 50 in.) occur in the Chemung and mid-Genesee River Valleys and near the Hudson River in Orange, Rockland, and Westchester Counties up to southern Albany County. On average, some of the winter snowpack is still unmelted by mid-March over all but the extreme southeastern part of the state. In mid-March, as much as 10 in. of water content can still remain in the snowpack of the Adirondack Mountains and in the highlands to the east of Lake Ontario.

The greatest potential for floods is in the early spring, when substantial rains combine with rapid melting of snow to produce heavy runoff. Almost half of the state's annual runoff occurs from mid-February through mid-May. Local flooding, primarily within smaller drainage basins, is generally caused by summer thunderstorms. Occasionally hurricanes can cause severe flooding, particularly in southeastern parts of the state. 


\section{Magnitude and Frequency of Flood Discharges}

This section of the report describes the database and the approach to developing equations used to estimate peak discharges for selected recurrence intervals at gaged and ungaged stream locations. A DVD that provides GIS datasets and procedures to compute flood frequencies is included with the report.

\section{Database}

The regression equations that provide estimates of the streamflow characteristics in this study were developed from records of annual peak discharges and basin-characteristic data from rural, unregulated gaging stations in New York (excluding Long Island) and adjacent states. Annual peakdischarges were obtained from the USGS peak-flow file; basin-characteristic and climate data were derived from (GIS) data sets and procedures.

\section{Annual Peak-Discharge Records}

The annual peak-discharge data that were the basis for this study were collected through September 1999 from 388 continuous-record and partial-record streamflow-gaging stations (locations are shown in fig. 2). Of these sites, 341 are in New York, and 47 are in adjacent states. Periods of peak-discharge record for these stations range from 10 to 99 years. Flood frequencies for some sites where significant flooding has occurred since 1999 (through 2005) have been updated accordingly.

The annual peak flows that were selected for analysis were recorded at streamflow-gaging stations in rural areas that had at least 10 consecutive years' record of unregulated flow. Streams were considered regulated if more than 25 percent of the drainage area above the streamflow-gaging station was upstream from a controlled reservoir, in accordance with analyses by Zembrzuski and Dunn (1979). An additional consideration in the assessment of significant effects of flood detention was the flood-control regulation criterion established by Benson (1962), namely, that basins with "usable storage" of more than 4.5 million $\mathrm{ft}^{3} / \mathrm{mi}^{2}$ are significantly affected by flood detention (storage could affect peak discharge by more than 10 percent). Usable storage is the volume of water normally available for release from a reservoir, between the minimum and maximum controllable elevations. Based on available storage data, the 388 sites used in this study were considered unregulated. Sites were considered "urbanized" (not rural) if more than 15 percent of the drainage area was affected by manmade changes (impervious area, channelization, diversions, and so forth) (Sauer and others, 1983).

The drainage areas of the 388 gaging stations used in the analysis ranged from 0.41 to $4,773 \mathrm{mi}^{2}$. A list of the 388 streamflow-gaging stations used in the study, their locations, drainage area, period of record, maximum known discharge, and recurrence interval, is given in table 7 (at the end of the report). Much of the information in table 7 was published previously (Lumia and Murray, 1993).

A graph of 13,925 annual peak discharges recorded at the 388 sites used in the study are plotted in relation to drainage area in figure 3; also shown are the 100-year peak discharges at each site (discussed later) and a maximum-known-discharge envelope curve for New York (Lumia and Murray, 1993). The envelope curve is based on discharges at 1,280 gaging stations throughout the State. At most of the 388 sites, the 100-year discharge exceeds the maximum discharge, yet most are well below the envelope curve for New York.

Annual peak discharges at 435 streamflow-gaging stations (including 47 urbanized basins) with at least 10 consecutive years of record were examined for significant trends through the Kendall's tau test. The tau value is a measure of the correlation between the annual peak series and time (years). A trend was considered significant if the p-value (probability that no trend is erroneously rejected) was less than or equal to 0.05 . This represents a 95-percent confidence level. Trends in flow records can be difficult to detect where periods of record are short and where outliers are present. Of the 435 sites having at least 40 years of record, a significant trend was indicated at 28 sites (6.4 percent of the sites). Of these trends, 21 were positive (general increase in annual peak discharges through time) and 7 negative. Trends were indicated at some other sites, but the period of record at these gages was generally much shorter than 40 years. Many of the sites showing a positive trend are in the extreme southeastern part of New York or on Long Island, which have undergone more extensive development over the years than most other parts of the State. The effect of urbanization can be seen through a comparison of trends for two urban sites (figs. 4A, 4B) with that for a rural area (fig. 4C). The two urban sites show strong positive trends, whereas the rural site shows a small but statistically significant negative trend.

Several other sites in the Susquehanna River Basin showed negative trends. The reason is unknown, but may be related to trends in precipitation and (or), to a lesser degree, ground-water levels (Rasmussen and Perry, 2001), or to extreme climatic anomalies near the beginning and the end of the record, to which the trend test is sensitive. The absolute value of the Kendall tau values for the 388 sites on rural, unregulated streams in this study was generally much lower than a "strong" value of about 0.7 or larger (Helsel and Hirsch, 1992, p. 212). The absence of flow regulation and urbanization in these basins together with possible climatic influences at the 388 sites suggests that any indicated trends probably were not a function of manmade changes that affect annual peak flows at these sites. Therefore, none of the 388 sites were excluded despite slight positive trends at some. Further study would be needed to explain the indicated trends.

A plot of annual peak runoff for all 388 sites from 1865 through 2002 (fig. 5A), indicates a slight positive trend that 


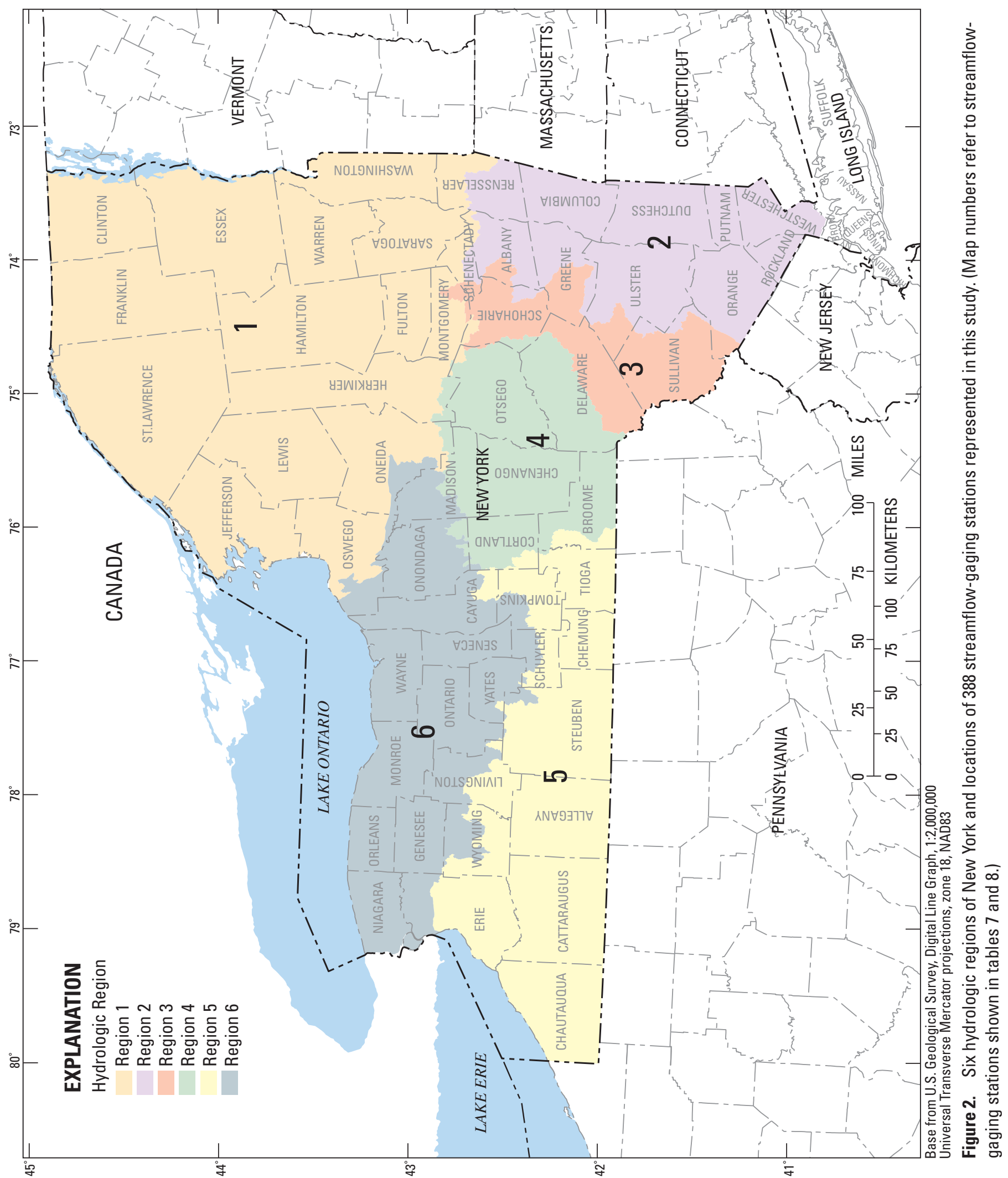




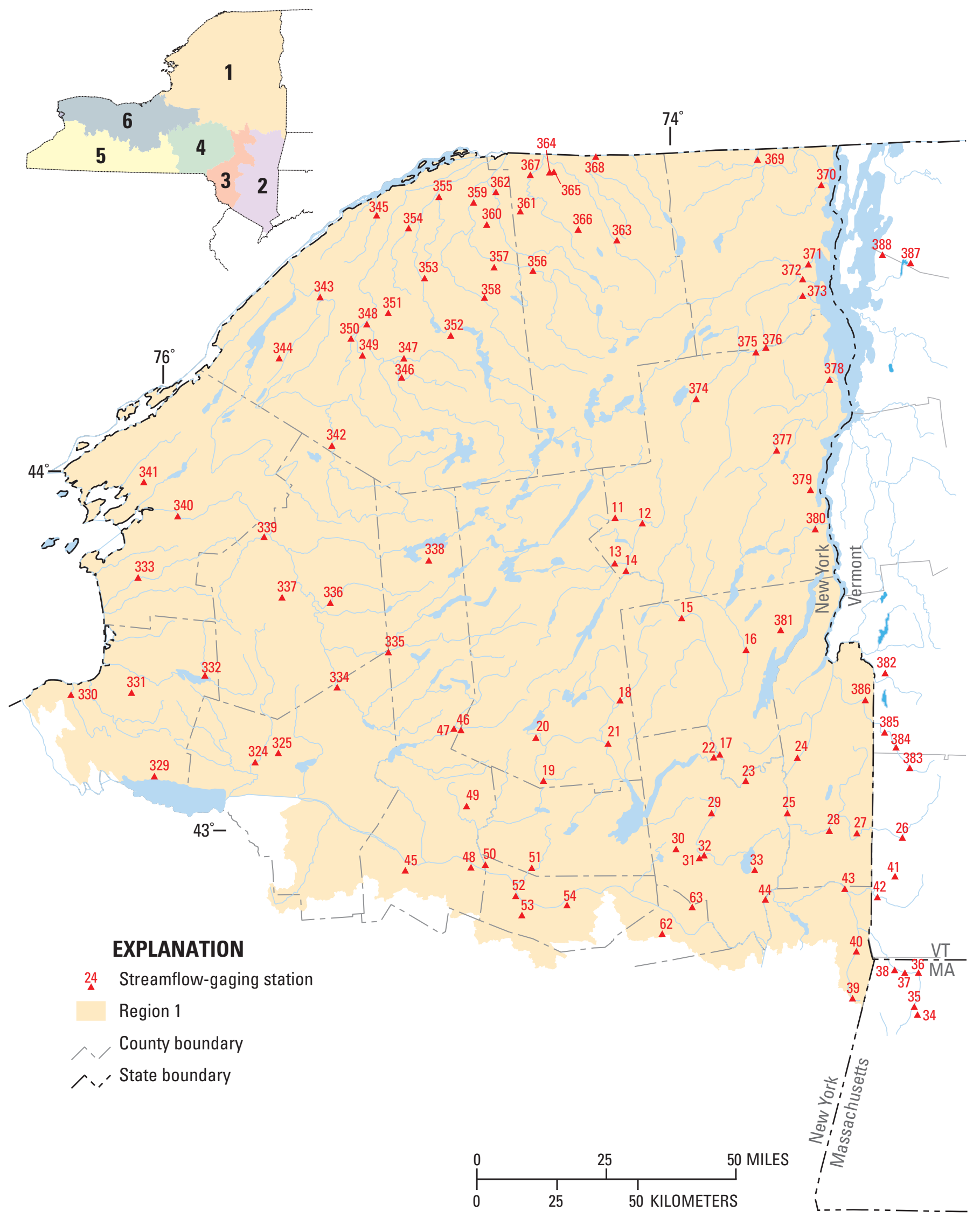

Figure 2. Six hydrologic regions of New York and locations of 388 streamflow-gaging stations represented in this study. (Map numbers refer to streamflow-gaging stations shown in tables 7 and 8.) —Continued 


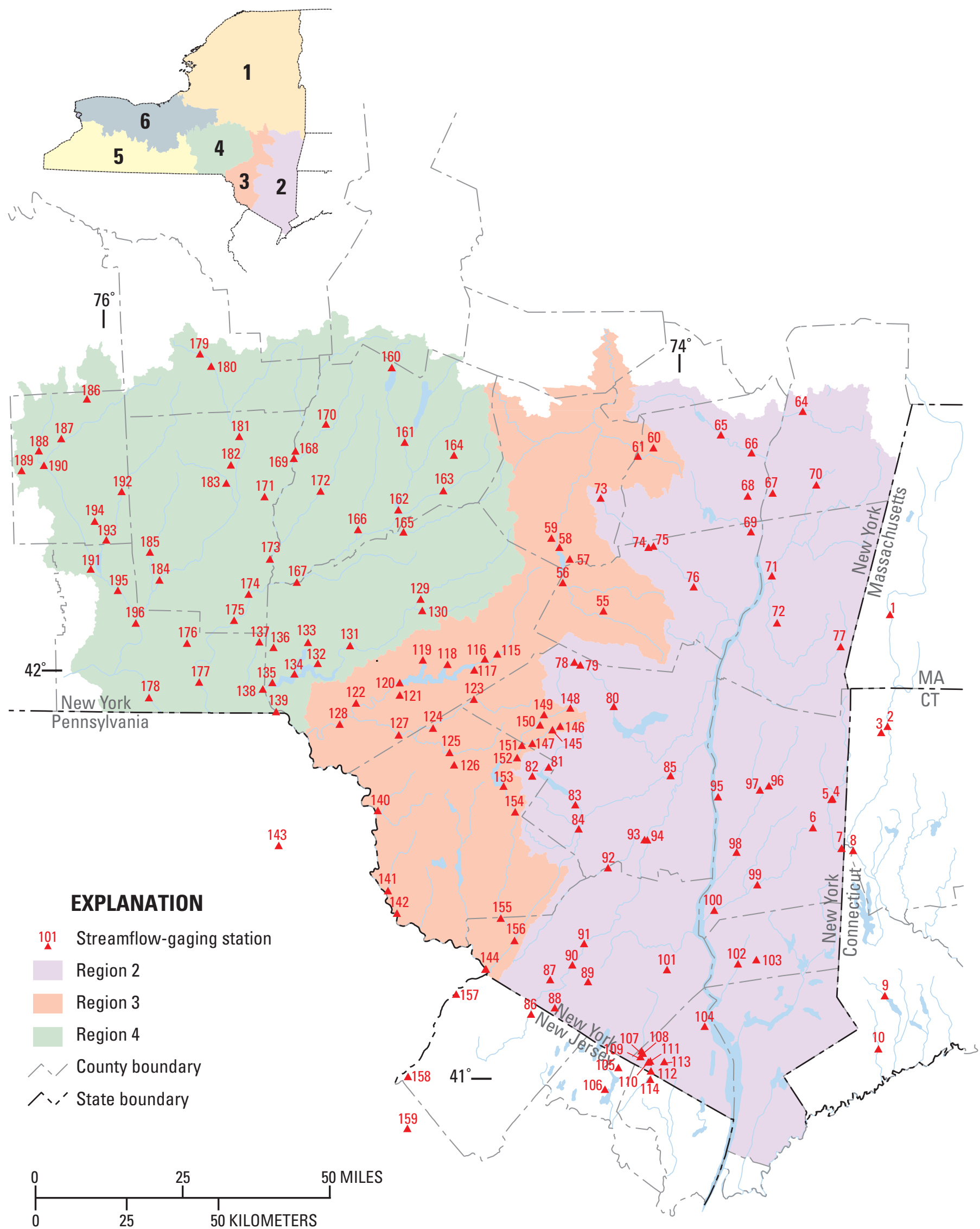

Figure 2. Six hydrologic regions of New York and locations of 388 streamflow-gaging stations represented in this study. (Map numbers refer to streamflow-gaging stations shown in tables 7 and 8.)-Continued 


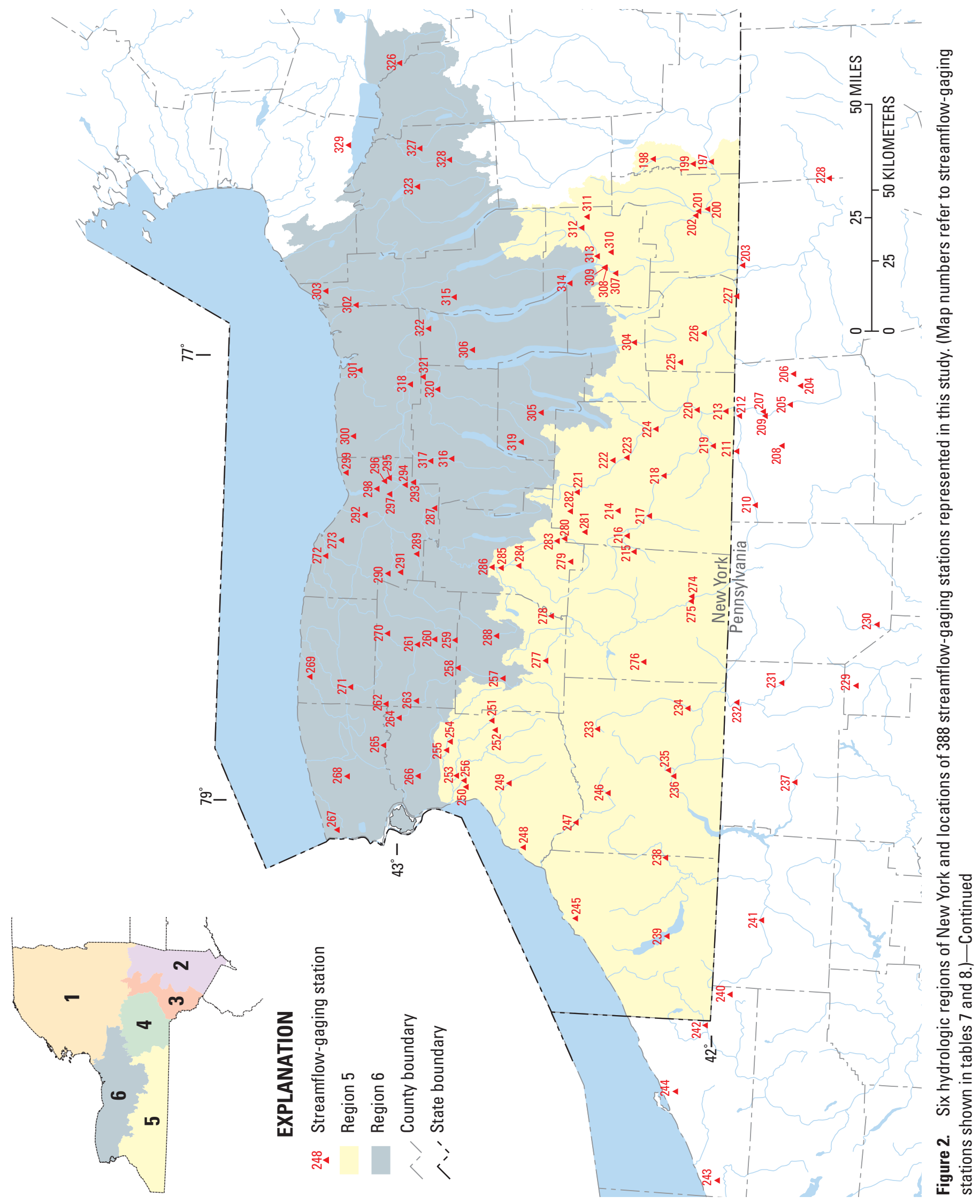




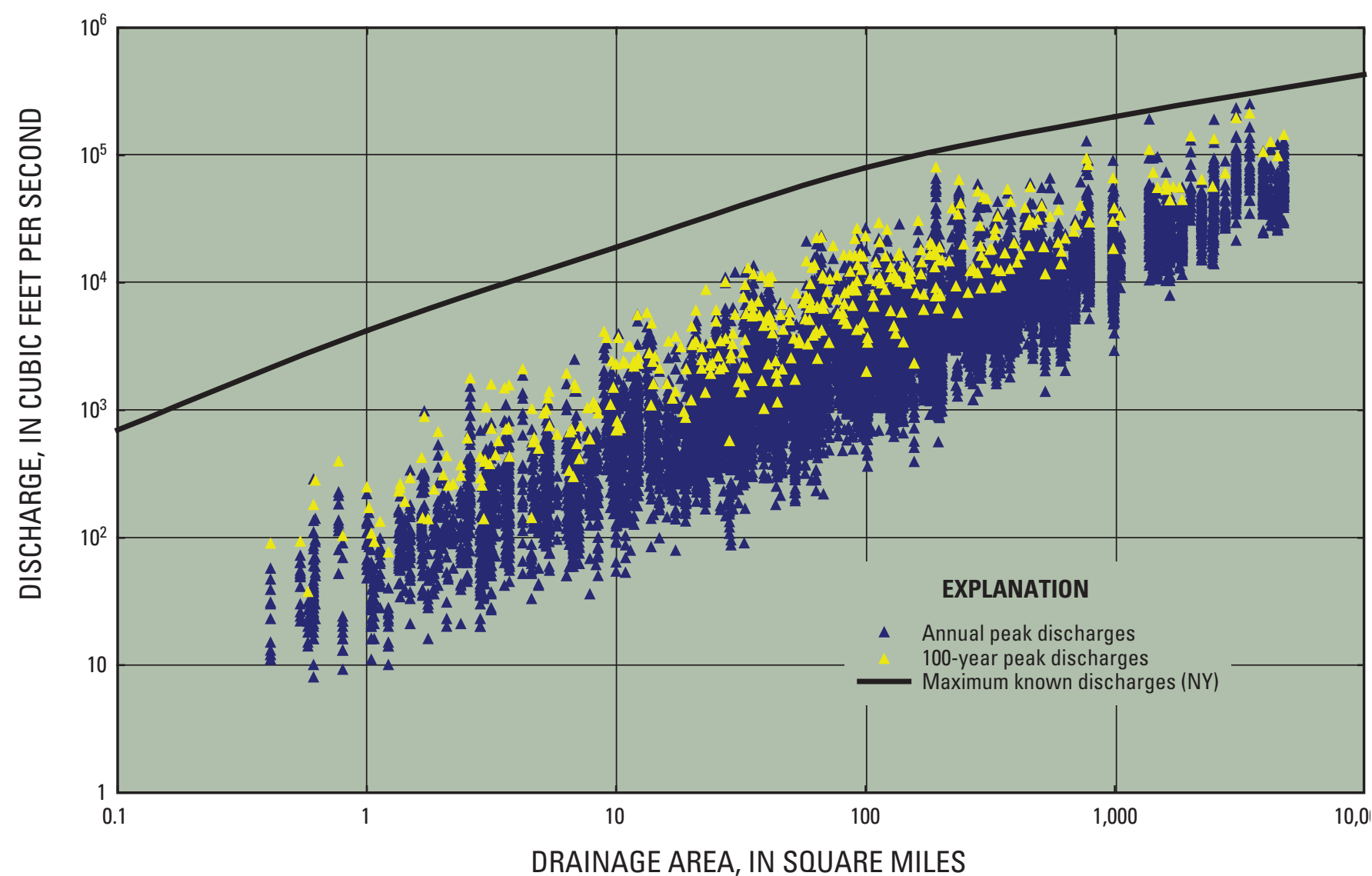

Figure 3. Annual peak discharges and 100-year peak discharges for 388 rural, unregulated streamflow-gaging stations used in this study.

is not statistically significant. One reason for this trend may be that stations on several small streams were added to the network through time and small basins generally produce greater peak runoff than large basins. A plot of annual peak runoff at small streams (drainage area 10- to 50- $\mathrm{mi}^{2}$ ) from 1913 through 2002 (fig. 5B) indicates a slightly negative trend, that is not statistically significant.

\section{Magnitude and Frequency of Flood Discharges at Streamflow-Gaging Stations}

The relation of flood-discharge to frequency of occurrence at a streamflow-measurement site is generally expressed in terms of exceedance probability or recurrence interval. Exceedance probability is the probability that a flood-discharge of specified magnitude will be equaled or exceeded in any 1 year. Recurrence interval, the reciprocal of exceedance probability, is the average time interval between occurrences of a flood-discharge of equal or greater magnitude. For example, a 100-year flood has a 1-percent chance of occurring in any 1 -year period.

Four representative flood-frequency curves are depicted in figure 6. A flood-frequency curve for each of the 388 gaging stations used in this study was developed by fitting the logarithms of the annual peak discharges to a Pearson Type-III distribution according to guidelines recommended by U.S. Water Resources Council (1981); the resulting data were analyzed through USGS flood-frequency programs (Kirby, 1981), and the frequency curves were adjusted to reflect historical information and high and low outliers. The coefficient of skewness was estimated as a weighted average of the systematic (station) skew and a generalized skew from a contoured skew map for New York (Lumia and Baevsky, 2000). Results of the discharge-frequency analyses for each gaging station are summarized in table 8 (at the end of the report). Caution must be exercised in using information from some of the stations listed in table 8 because several of the streams are now regulated. The discharges given in table 8 for streams that are currently regulated reflect pre-regulation periods and are not generally applicable to present conditions.

Discharge-frequency estimates for 122 gaging stations on streams with significant regulation or urbanization are listed in table 9 (at the end of the report). The discharge-frequency estimates were derived from the annual peak-discharge data for the regulated or urbanized period using recommended statistical procedures discussed earlier (U.S. Water Resources Council, 1981). The high degree of regulation or urbanization required use of the station skew rather than a weighted skew. These 122 sites were not used in the regional regression 
A. 01311000 -- Pines Brook at Malverne, Long Island
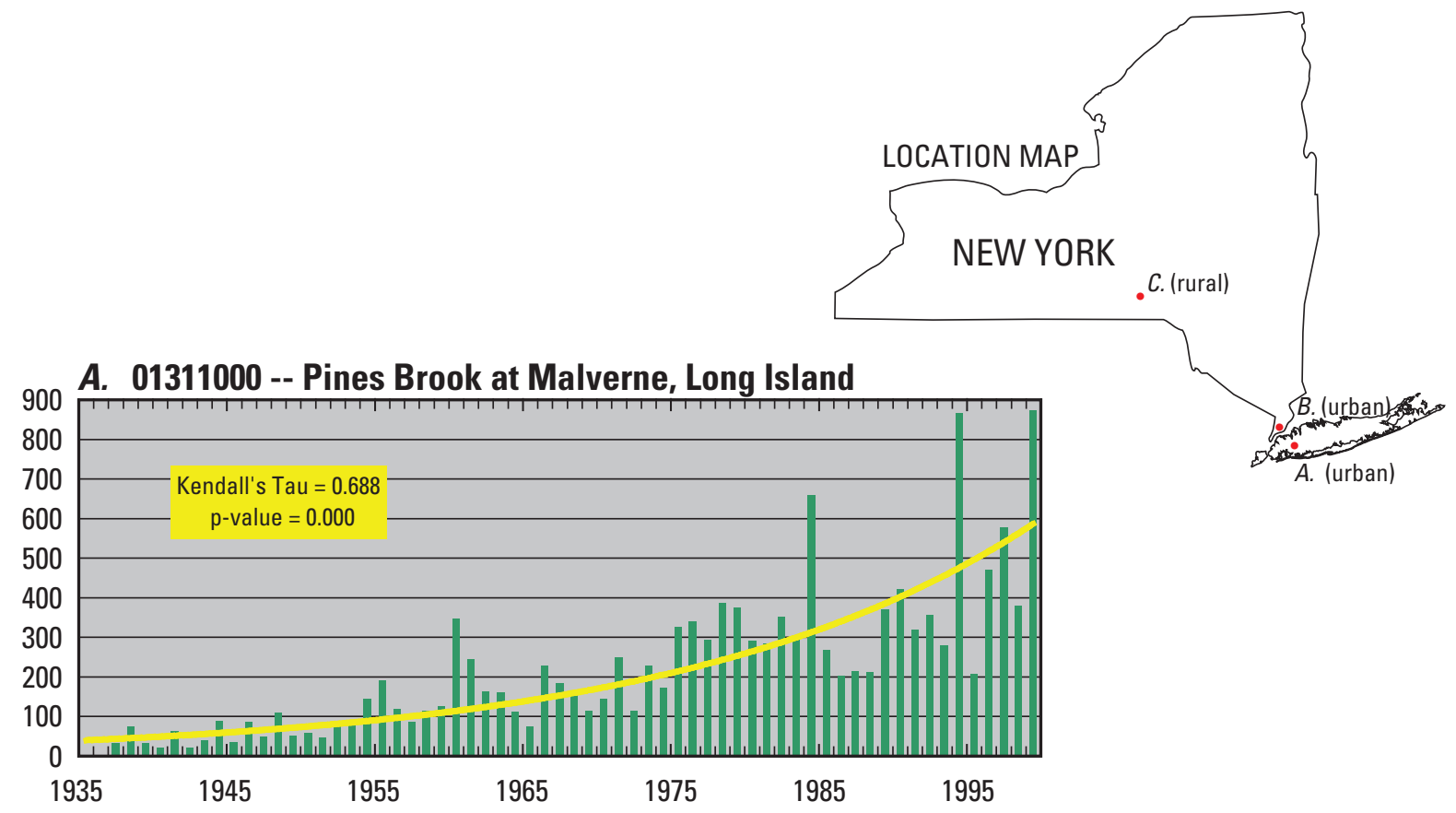

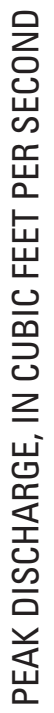

B. 01302000 -- Bronx River at Bronxville

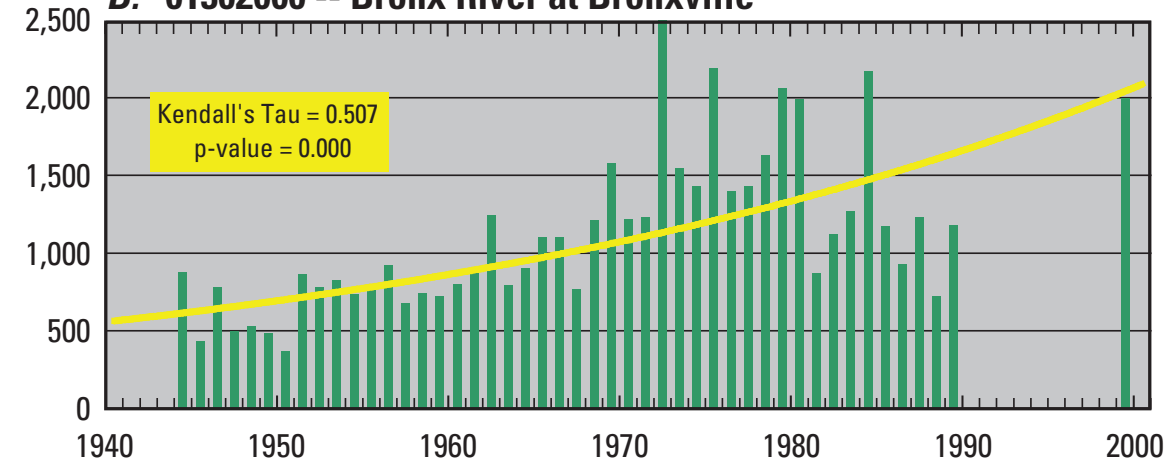

C. 01512500 -- Chenango River near Chenango Forks

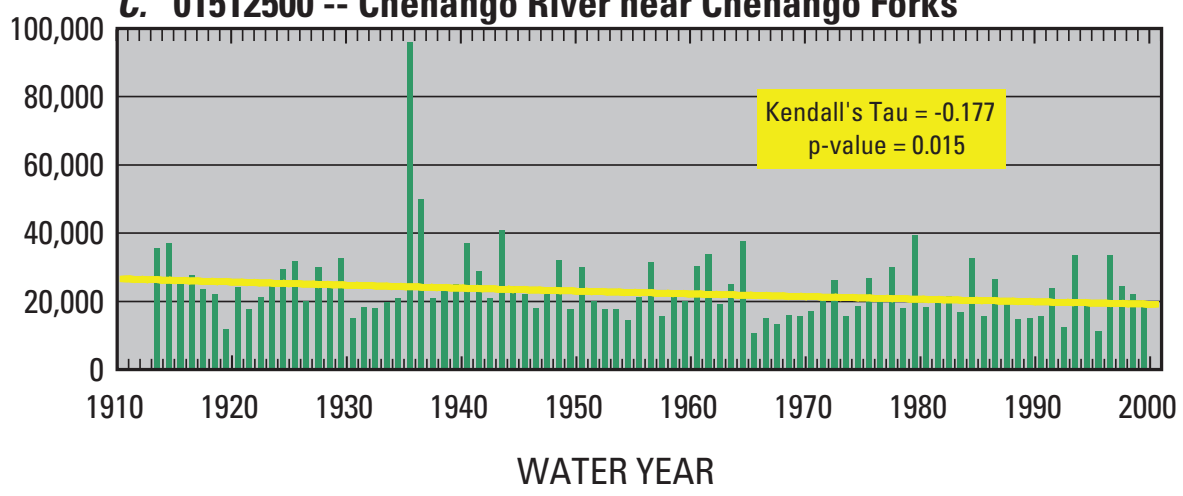

Figure 4. Annual peak discharges and trend line for streams in two highly developed areas $(A, B)$ and in an undeveloped area $(C)$ in New York: $(A)$ 01311000-Pines Brook at Malverne, $(B)$ 01302000-Bronx River at Bronxville, and $(C)$ 01512500-Chenango River near Chenango Forks. (Location and peak-discharge data are given in tables 8 and 9). 


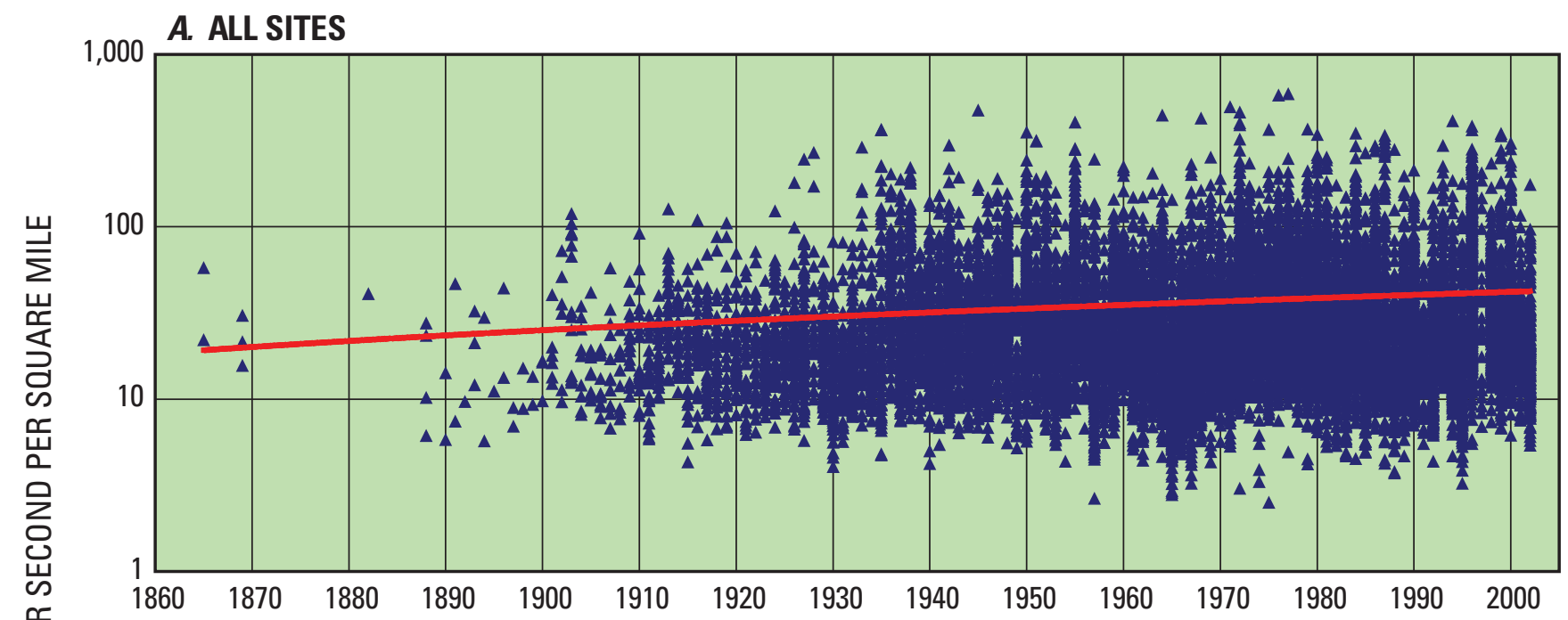

B. SMALL STREAM SITES

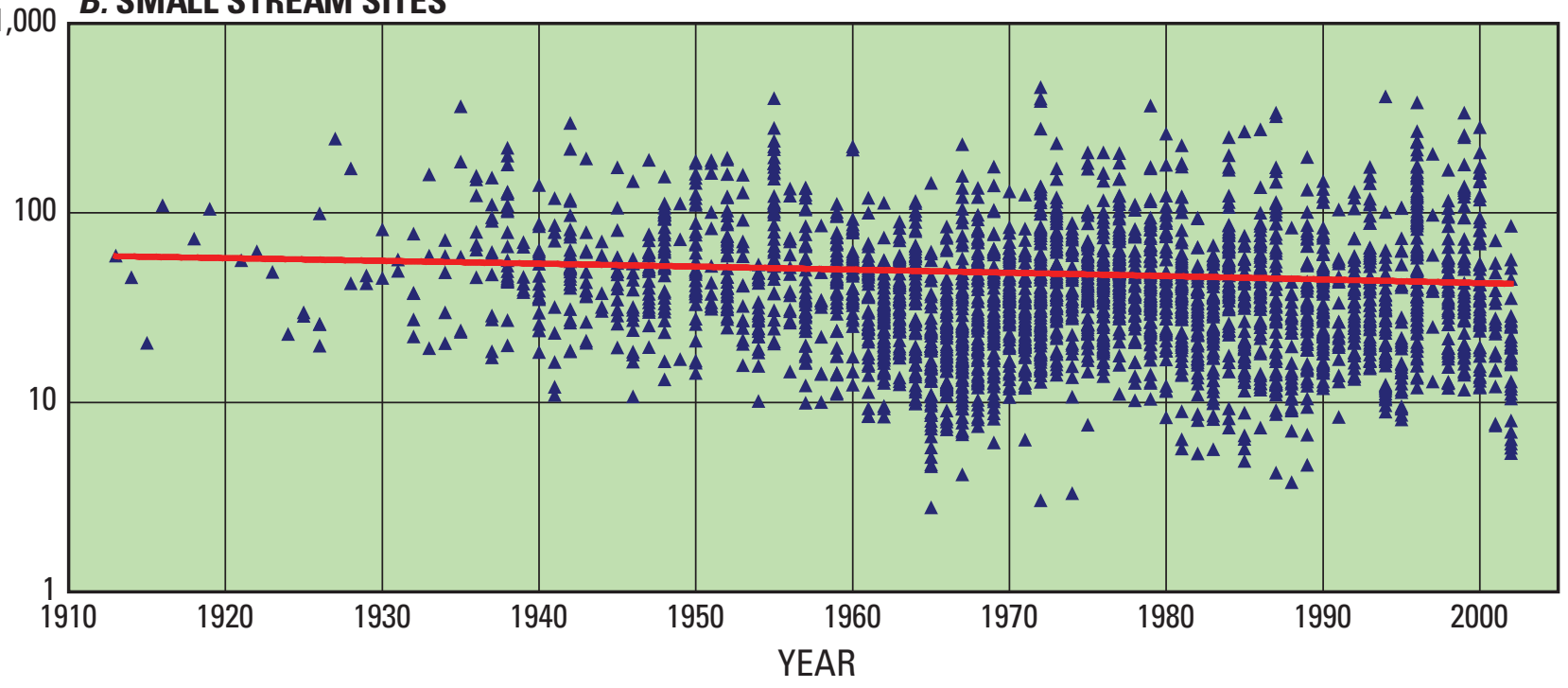

Figure 5. Annual peak discharges and trend lines for $(A)$ all study sites and $(B)$ all small stream (10- to 50-square miles) study sites.

analyses. At regulated sites, no adjustments were made for the amount of available storage in the reservoirs before or during floods, nor for changes in regulation procedures during the period of regulation. Other methods to estimate floodfrequency curves at reservoir outlets are available and can be applied to these sites. Computed discharge-frequency curves for urbanized basins with many years of record may not represent current conditions if the degree of development has increased significantly through time. A period with a relatively constant degree of urbanization has been defined, as a general guideline, as a change in development (commercial, industrial, or residential) of less than 50 percent during the period of record (Sauer, 1983). The locations of streamflow-gaging stations on streams that currently have a substantial amount of regulation or urbanization are shown in figure 7.

As noted earlier, frequency curves are adjusted to account for historical information, outliers, and skew of the distribution of annual peak discharges. To illustrate the effects of a high outlier and a historic period-of-record, annual peak discharges (1913-2002) for Chenango River near Chenango Forks, as well as "moving" 100-year and 2-year flood discharges are shown in figure 8A. Revised values were calculated for the period following the first 10 years of peak-discharge record and plotted in a continuous line as each "new" year of peak-discharge record was added. The continuous lines show computed values with no adjustments for the historic period (the 1935 peak discharge is the highest since at least 1865), whereas the triangles show computed discharges, for selected years, with such adjustment. The chart in figure 8A shows that the 1935 peak discharge had a major effect on the 100-year discharge but only a minimal effect on the 2-year flood-discharge. A similar graph for Independence River at Donnattsburg (fig. 8B) shows the effect of major floods much later during the record (early and mid-1980s) with no historic 


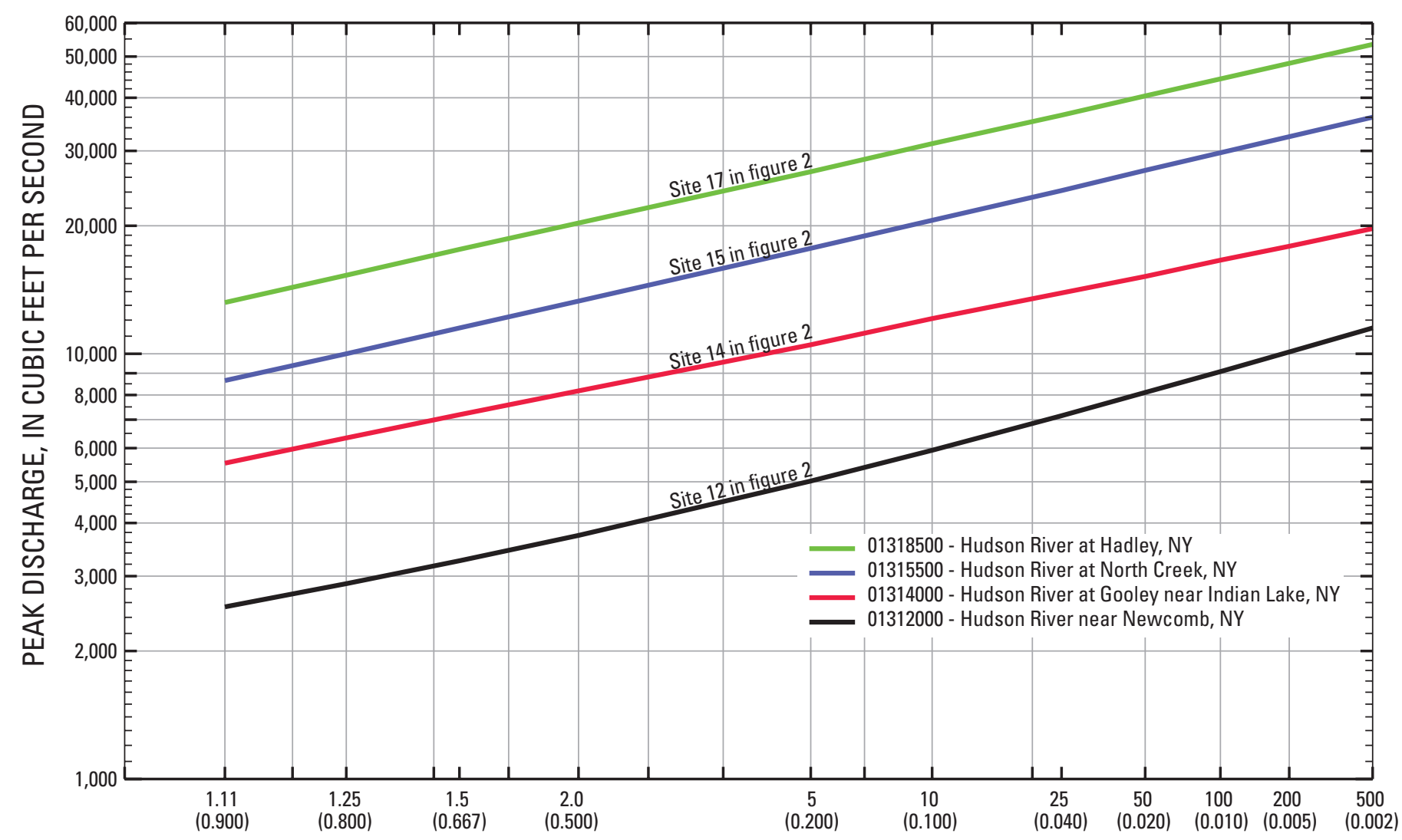

RECURRENCE INTERVAL, IN YEARS

(number in parentheses is exceedance probability)

Figure 6. Examples of flood-frequency curves for selected streamflow-gaging stations along the Hudson River in New York.

(pre-1943) information available. The computed 100-year discharge from the 1950s through 1980 was slightly more than $4,000 \mathrm{ft}^{3} / \mathrm{s}$; it then increased to nearly $7,000 \mathrm{ft}^{3} / \mathrm{s}$ after the flood of 1985. Again, the 2-year moving flood discharge showed little fluctuation during the period of record. The graphs in figure 8 give examples of the effect that high outliers and historic information can have on flood-frequency analyses (and the subsequent design of bridges and culverts).

\section{Basin Characteristics}

Peak-discharge information can be transferred to ungaged sites through multiple regression analysis that relates streamflow characteristics (such as 100-year flood discharge) to selected topographic and climatic characteristics for each gaged drainage basin. Values for many of the basin characteristics used in this study were obtained through a GIS in conjunction with a 30-m digital elevation model (DEM) (U.S. Geological Survey, 2001); the values for several characteristics were derived from a computer program through procedures described in Harvey and Eash (1995).

More than 60 basin and climate characteristics were tested for statistically significant correlation with peak flows during the regression analyses. Among those tested were drainage area, basin length, basin perimeter, average basin slope, basin relief, basin azimuth, basin width, basin-shape factor, basin-elongation ratio, basin rotundity, compactness ratio (basin perimeter to circumference of a circle of equal area), relative relief (basin relief to basin perimeter), total stream length, main-channel length, main-channel slope, main-channel sinuosity ratio (main-channel length to basin length), stream density (total stream length to drainage area), constant of channel maintenance (reciprocal of stream density), main-channel slope proportion (main-channel length to main-channel slope), ruggedness number (stream density times basin relief), slope ratio of main-channel slope to basin slope, number of first-order streams, basin stream order, drainage frequency (number of first-order streams per square mile), relative stream density (drainage frequency to stream density), basin-shape index, average main-channel elevation, minimum basin elevation, maximum basin elevation, average basin elevation, elevation at gage, percentage of basin that is urbanized, percentage of basin that is forested, percentage of basin with grasslands, percentage of basin storage, mean annual precipitation, mean annual snowfall, precipitation ratio (mean annual snowfall to mean annual precipitation), maximum seasonal snow depth, 100-year 24-hour precipitation, water equivalent of snowfall, total snowfall, mean annual runoff, average angle of basin slope, slope of lower half of main channel, slope of upper half of 

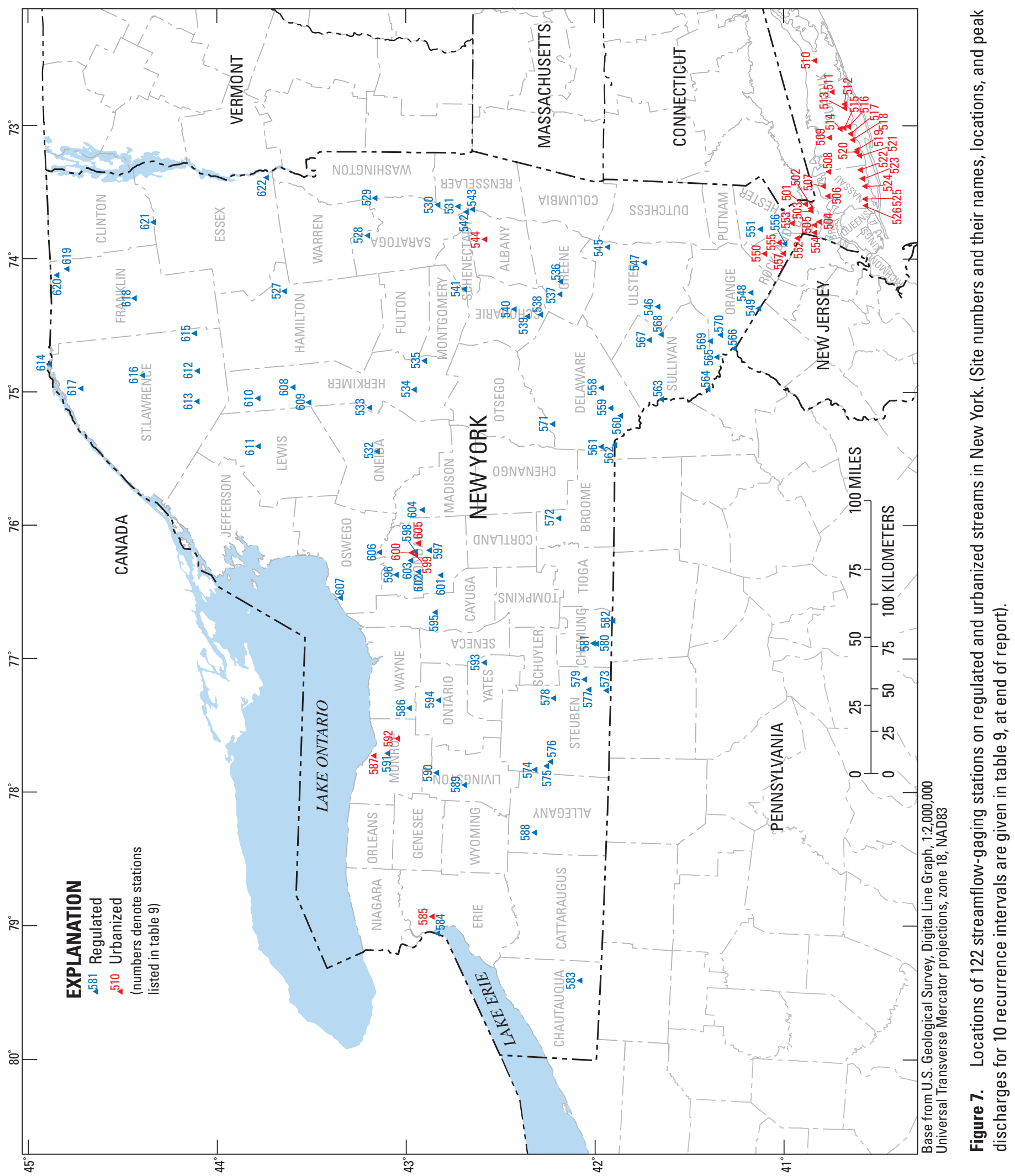


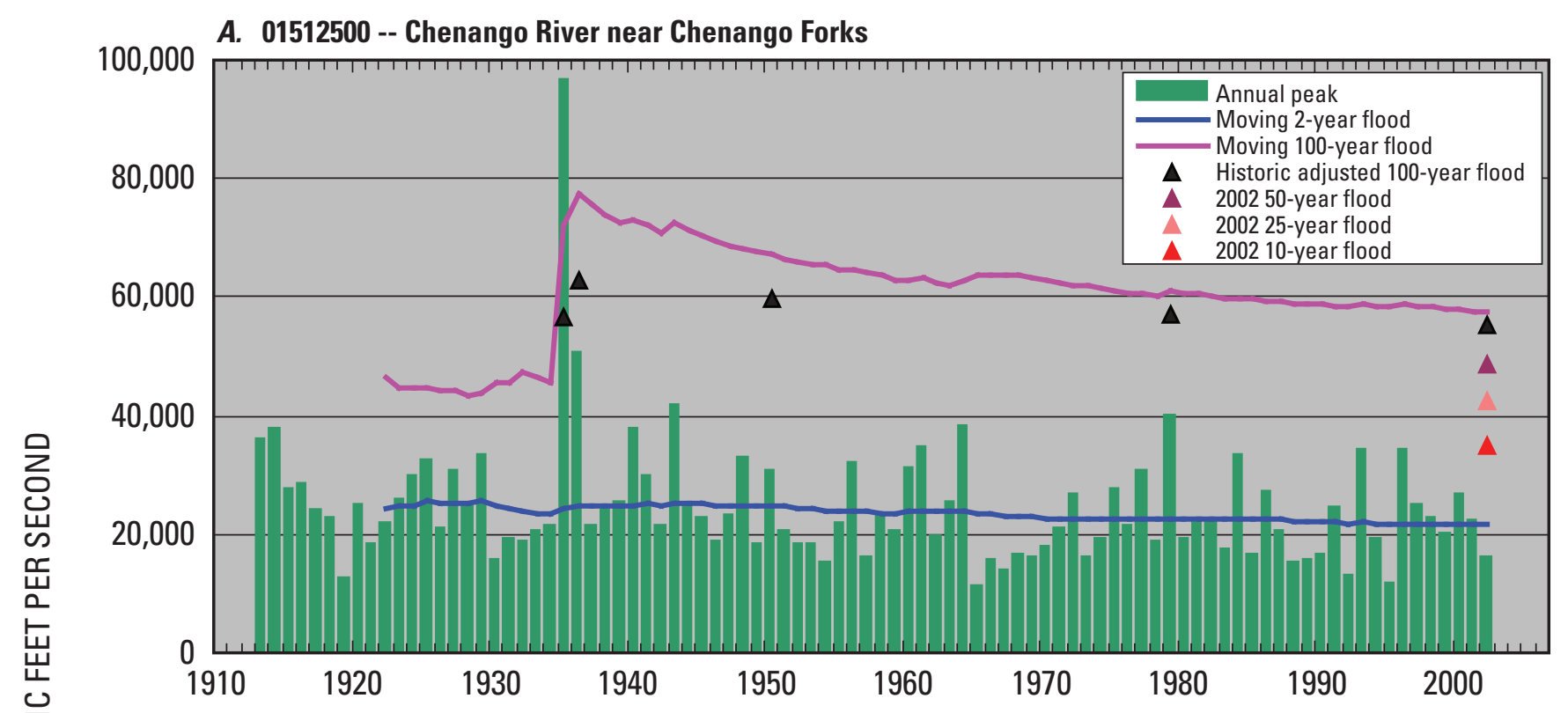

B. 04256000 -- Independence River at Donnattsburg

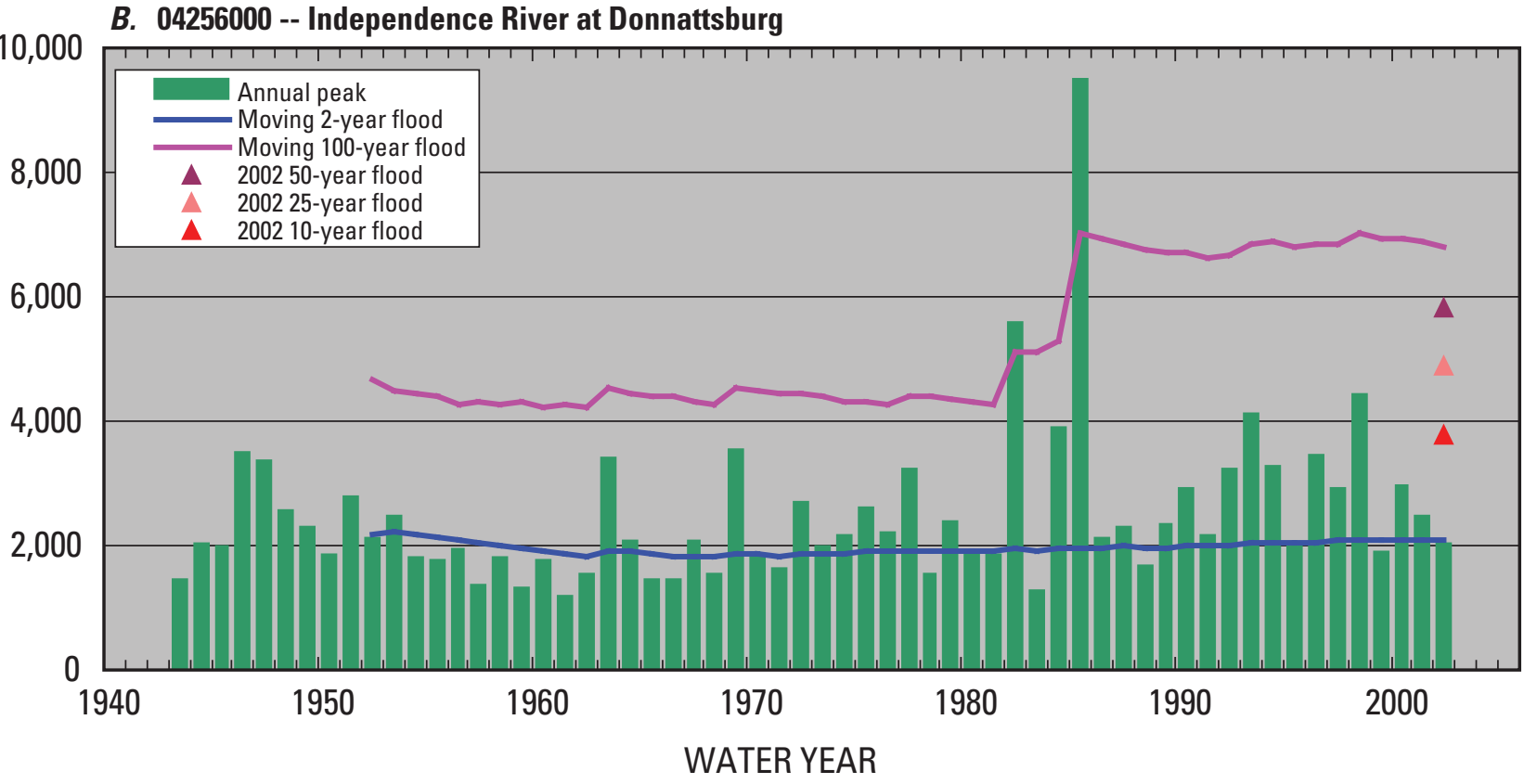

Figure 8. Annual peak discharges and moving 100- and 2-year flood discharges for two streamflow-gaging stations in New York: (A) 01512500 - Chenango River near Chenango Forks, and (B) 04256000 - Independence River at Donnattsburg. (Station locations are shown on figure 2 , site 336 , table 8 ).

main channel, percentage of basin above selected elevations, basin lag factor (relating main-channel length and slope), and several soil properties, including permeability, percent clay content, percent organic matter, and so forth. The variables that were selected for use in the final regression equations are defined as follows:
Drainage area (A), in square miles. - The area of a basin upstream from the gage or site of interest, delineated on 7.5-minute USGS topographic maps, then calculated by digitizing the basin outline (Wagner, 1982).

Main-channel stream length (L), in miles. - The longest flow distance measured along the main stream channel from 


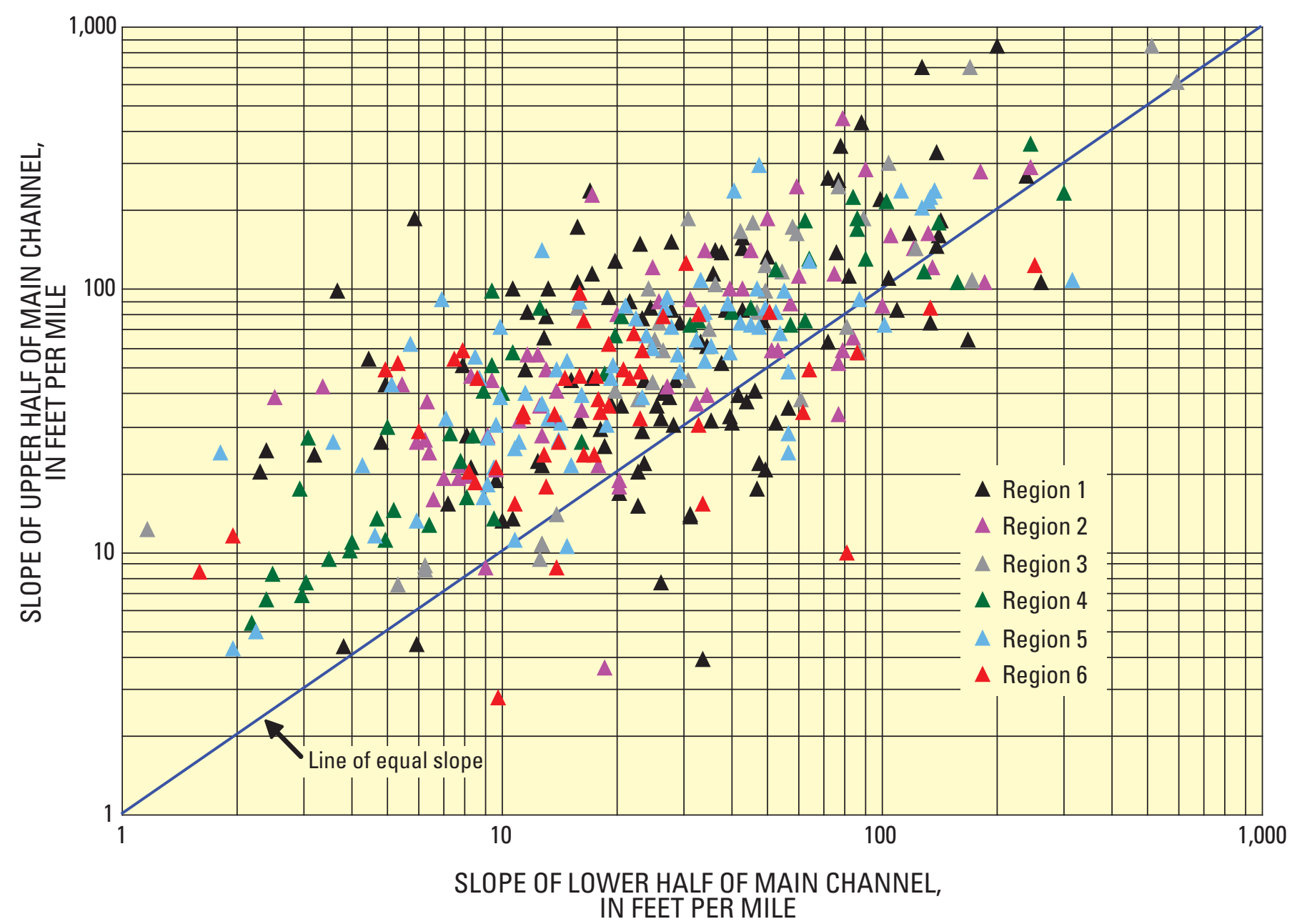

Figure 9. Slopes of the lower half and upper half of the main channel for 388 streamflow-gaging stations used in the study. (Hydrologic regions are shown in figure 2).

the gage or point of interest to the top of the basin. The main channel was derived from the 30-m DEM (U.S. Geological Survey, 2001).

Main-channel slope (SL), in feet per mile.- The difference in elevation (feet) between points 10 percent and 85 percent of the distance along the main stream channel from the gage or site of interest to the top of the basin, divided by the distance (miles) between the two points.

Slope of the lower half of the main channel (SL_LO), in feet per mile.- The difference in elevation (feet) between points 10 percent and 85 percent of the distance along the lower half of the main channel from the gage or site of interest to the midpoint of the entire main channel, divided by the distance (miles) between the two points.

Slope of the upper half of the main channel (SL_UP), in feet per mile.- The difference in elevation (feet) between points 10 percent and 85 percent of the distance along the upper half of the main channel from the midpoint of the entire main channel to the top of the basin, divided by the distance (miles) between the two points. Figure 9 shows a plot of the slopes of the upper and lower halves of the main channel for the 388 gaging stations used for this study.

Average basin slope (BS), in feet per mile.- - Slope measured by the contour-band method, within the contributing drainage area, where $\mathrm{BS}=[$ (total length of all selected elevation contours) (contour interval)] / A.

Slope ratio (SR) of main channel slope to basin slope, dimensionless. - Computed within the drainage basin as SL / BS.

Basin lag factor (LAG). - Computed as main channel length divided by the square root of the product of the slopes (plus one) of the upper and lower halves of the main channel,

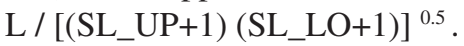

Percentage of drainage basin at or greater than 1,200 feet above sea level (EL12). - Computed from the 30-m DEM (U.S. Geological Survey, 2001). A relief map showing the areas above 1,200 feet is given in figure 10 . 


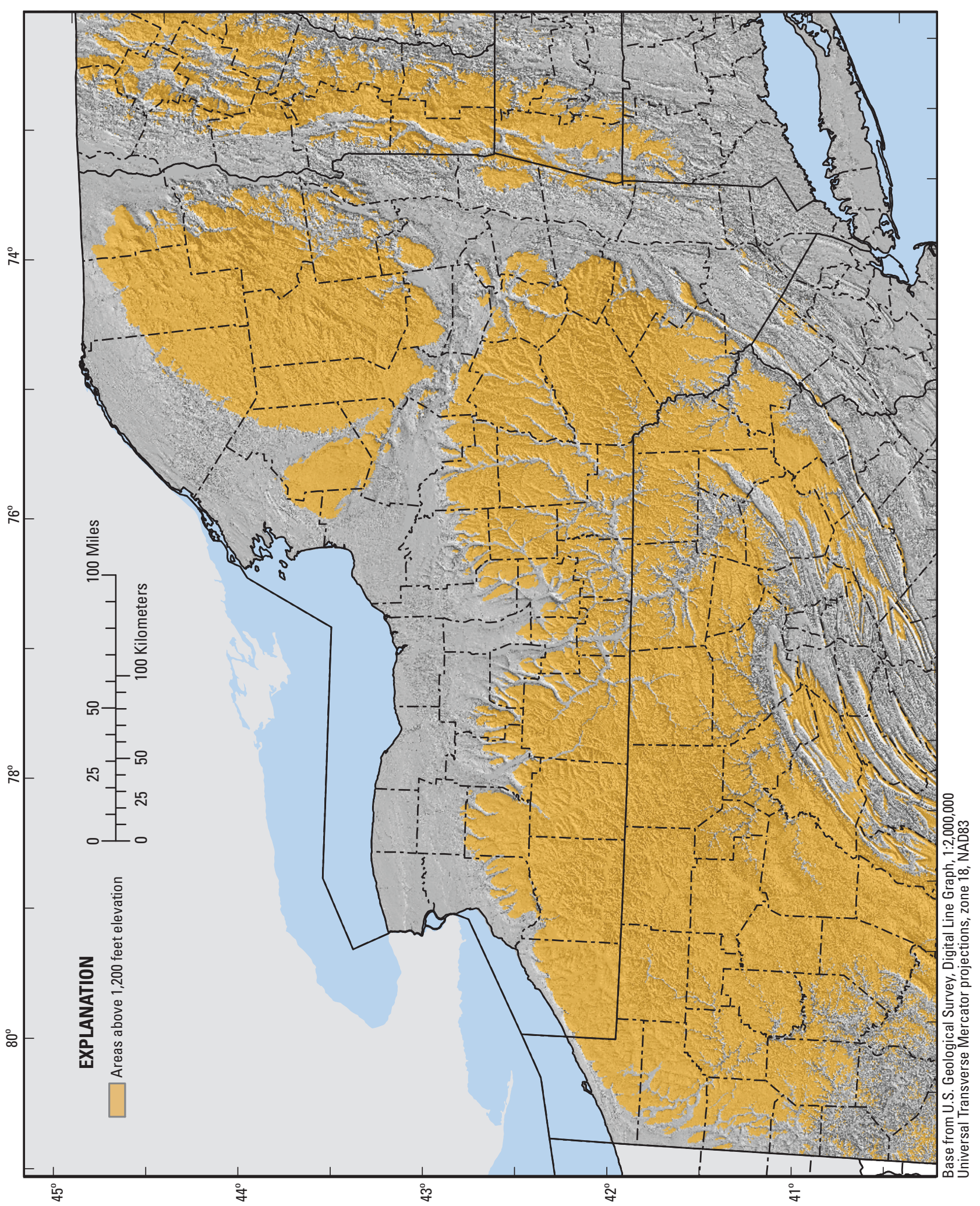

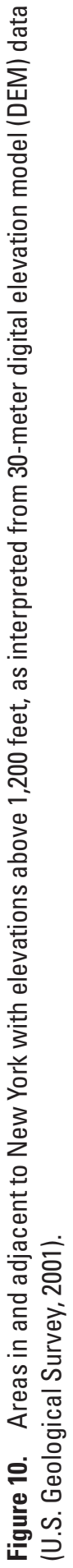


Basin storage (ST), in percent. - Percentage of total drainage area shown as lakes, ponds, or swamps (wetlands) in the National Land Cover Dataset (NLCD) (U.S. Geological Survey, 2000) land-use data. A generalized land-use map of New York and adjacent States showing areas of storage, as well as urban and forested land, is given in figure 11.

Basin forested area (FOR), in percent. - Percentage of total drainage area shown as forest cover in the National NLCD) (U.S. Geological Survey, 2000 land-use data. A generalized land-use map of New York and adjacent States showing areas of forested land, as well as urban land and areas of basin storage, is given in figure 11.

Mean annual runoff (RUNF), in inches. - The average value for the basin calculated from a gridded contour map of mean annual runoff for 1951-80 (Randall, 1996). A map of New York and adjacent States showing mean annual runoff is given in figure 12.

Mean annual precipitation (P), in inches. - The average value for the basin calculated from a gridded contour map of mean annual precipitation for 1951-80 (Randall, 1996). A map of New York and adjacent States showing mean annual precipitation is given in figure 13.

Seasonal maximum snow depth, $50^{\text {th }}$ percentile (MXSNO), in inches. - The average value for the basin computed from Northeast Regional Climate Center (NRCC) atlas of snowfall and snow depth (Cember and Wilks, 1993). A map of New York and adjacent States showing seasonal maximum snow depth is given in figure 14 .

Of the 14 variables that were selected for this analysis, eight represent aspects of basin morphology (L, SL, SL_LO, SL_UP, BS, SR, LAG, EL12 ). Their values were calculated for each gaged basin from the 30-m National Elevation Dataset (U.S. Geological Survey, 2001). The basis for computation of all basin characteristics was the drainage basin outlines that had been manually delineated by Wagner (1982). Figure 9 shows a plot of the slopes of the lower half and the upper half of the main channel for each of 388 streamflow-gaging stations used in the study. The sites are shown by hydrologic region. Most slopes of the upper half of main channels are greater than the lower half, but several sites indicate the lower half to be steeper than the upper half. Further investigation is needed to determine what effect these main channel slope conditions have on resulting peak discharges.

Two of the 14 selected variables represent land-cover characteristics (ST and FOR). Their values for each site were computed from NLCD for 1992 at a 30-m cell size (U.S. Geological Survey, 2000). Storage (ST) represented the openwater and wetland categories; forest cover (FOR) represented three categories combined (deciduous, evergreen, and mixed). The degree of urbanization in a basin was calculated as the sum of (0.4) low-density residential, high-density residential, and commercial land. Urbanization was calculated only to determine if a site should be excluded from the analysis. It was not a variable in the regression analyses.
Mean annual runoff (RUNF) values were taken from an analysis by Randall (1996), that was based primarily on records of streamflow (1951-80) at 503 gaged sites across the Northeast. The resulting contour map was gridded through GIS techniques to compute the average runoff value for each basin in this study.

Mean-annual precipitation $(\mathrm{P})$ values were taken from an analysis by Randall (1996) that was based primarily on records of precipitation (1951-80) at 483 precipitation stations across the Northeast. Precipitation values were compared to runoff values for consistency and adjusted accordingly (Randall, 1996). Average values were computed for each gaged basin.

Average values for seasonal maximum snow depth, $50^{\text {th }}$ percentile (MXSNO) were computed from the Northeast Regional Climate Center (NRCC) atlas of snowfall and snow depth. A raster dataset was developed from the contour map in the atlas, and an average value for each gaged basin was computed. The period of record for climate stations used in the atlas was from October 1955 through April 1992 for Northeastern states (Cember and Wilks, 1993).

Values for each of the 14 variables used in the regional regression analyses are listed by USGS site number in table 10 (at the end of the report).

\section{Regression Analysis}

Multiple regression analysis was used to develop the relations between peak discharges of selected recurrence intervals (response variable) and drainage-basin characteristics (the 14 selected explanatory variables). Previous regression analyses for New York used (OLS) procedures (Zembrzuski and Dunn, 1979) and (GLS) procedures (Lumia, 1991). The OLS estimates are appropriate if three conditions are met: (1) all flow estimates are equally reliable, (2) the natural variability is the same for each site, and (3) observed concurrent flows at every pair of sites are independent of each other. In practice, available data seldom fully meet these requirements, however.

Research by Stedinger and Tasker (1985) and Tasker and Stedinger (1989) showed that GLS may be more appropriate for hydrologic regression than OLS. In this approach, the regression coefficients are estimated by taking into consideration the time-sampling error (length of record at each site) and the cross correlation of annual peak-discharges between sites. This research has shown that the GLS procedure was superior to OLS where streamflow data are cross correlated and (or) have differing lengths of record.

GLS regression entails weighting each basin in accordance with the variance (time-sampling error) and spatial-correlation structure of the streamflow characteristic (annual peak discharges); it also accounts for the timesampling error in the streamflow characteristic when the accuracy of the regression equation is evaluated. The prediction error for ungaged sites is partitioned into regression error (error in assuming an incomplete regression form) 


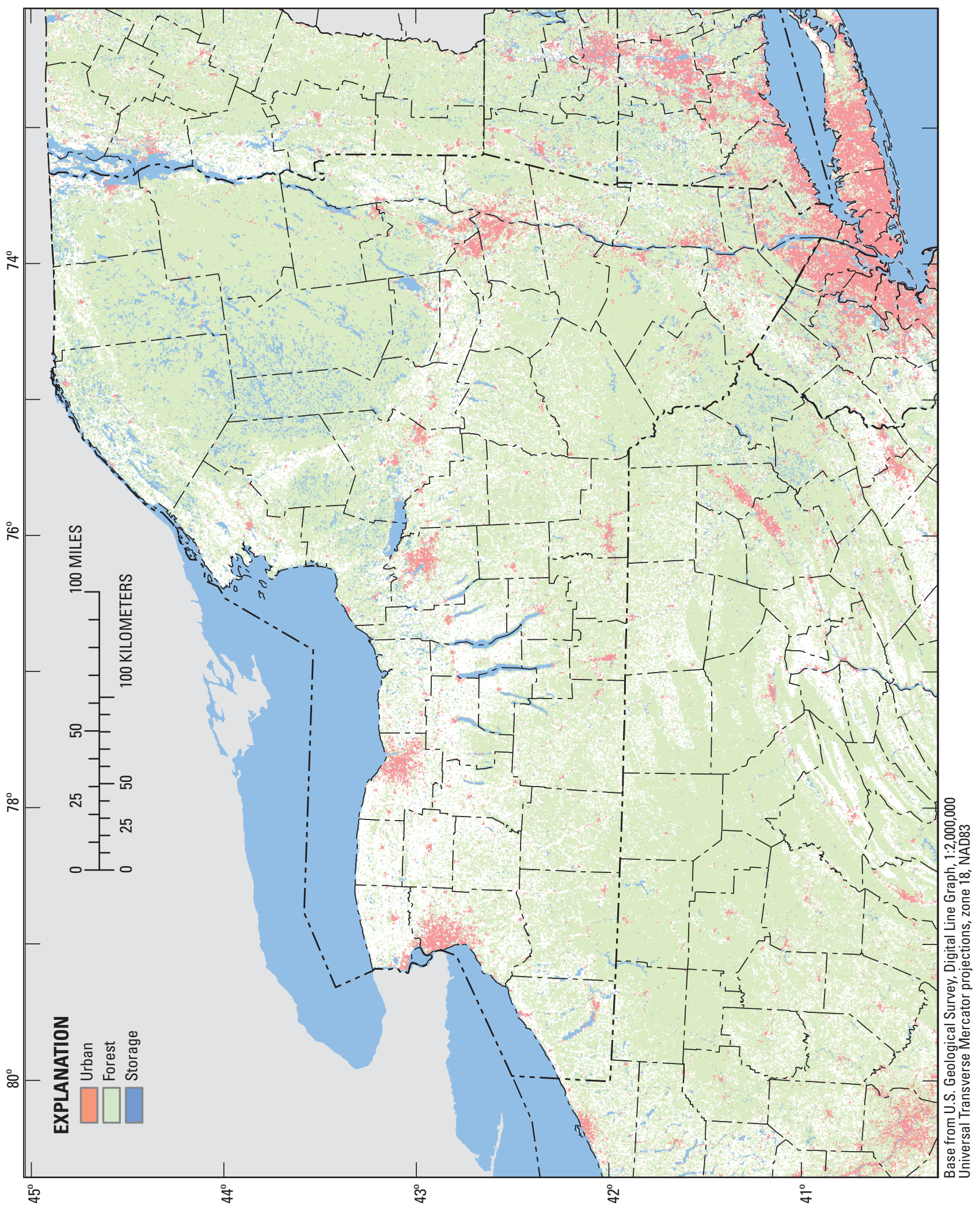

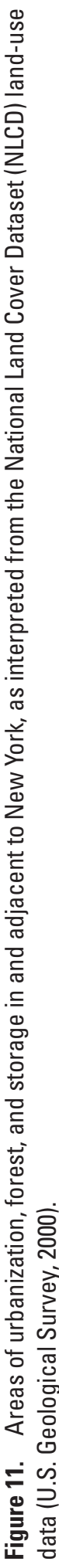




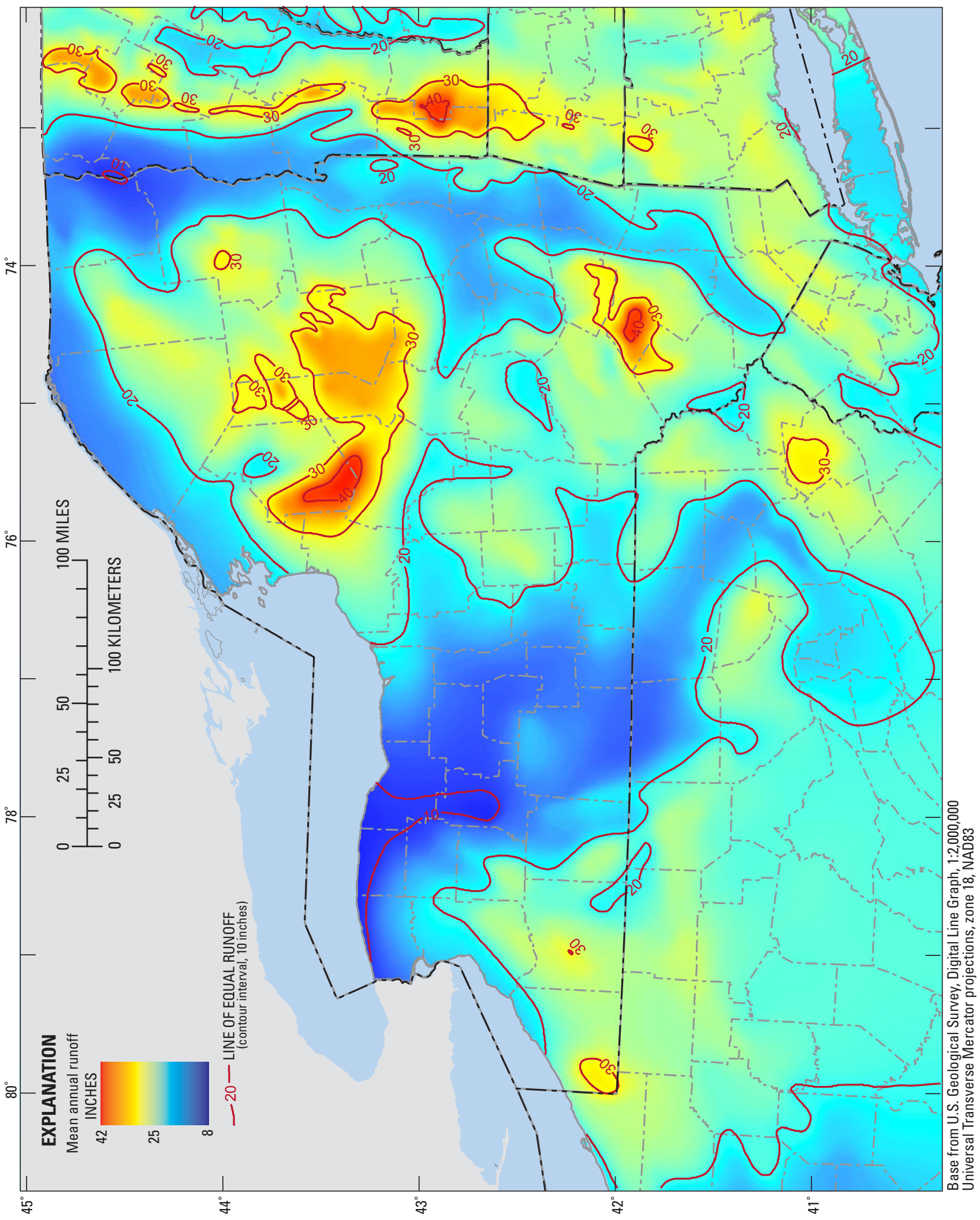

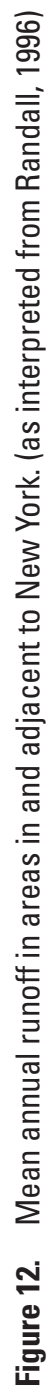




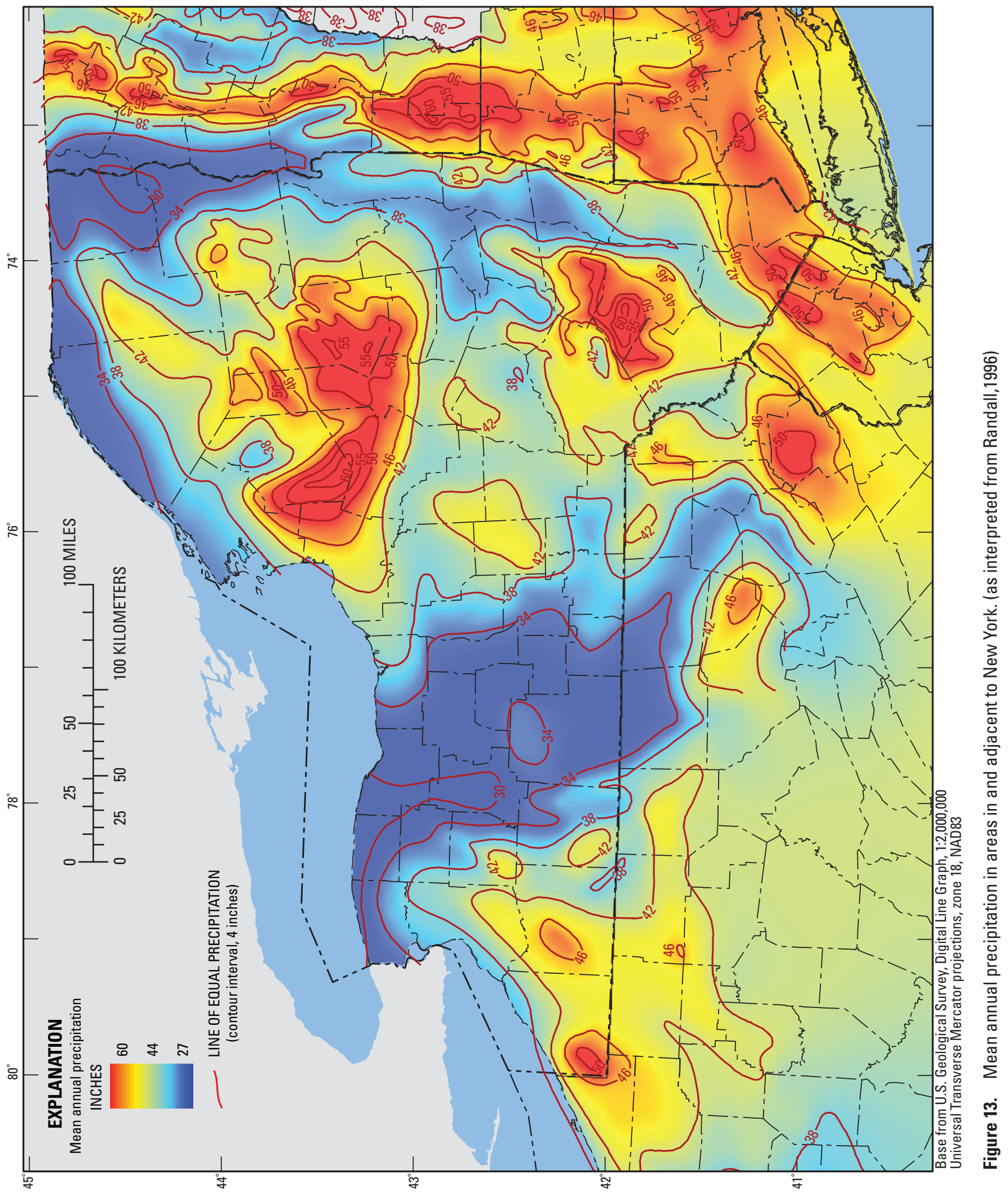




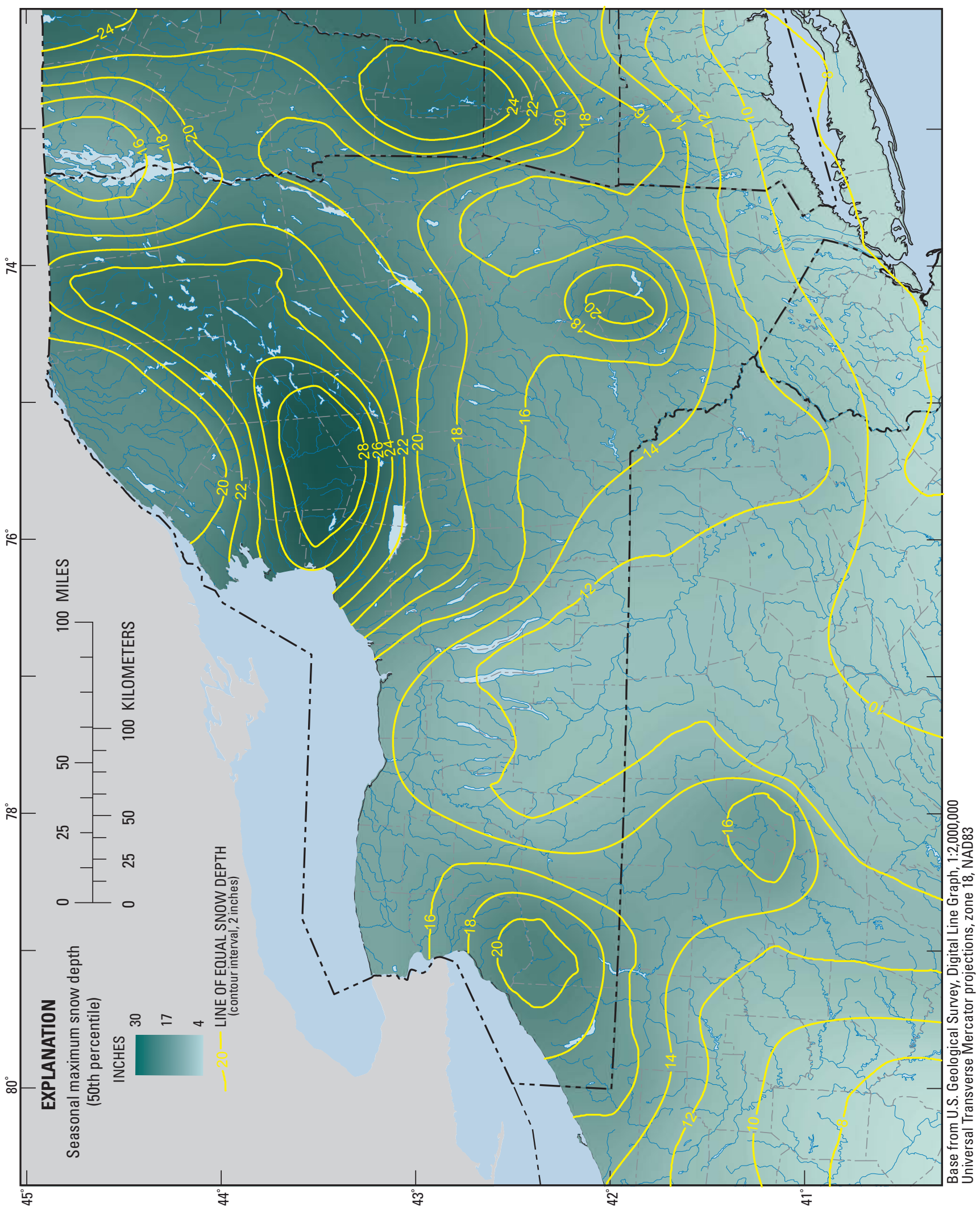

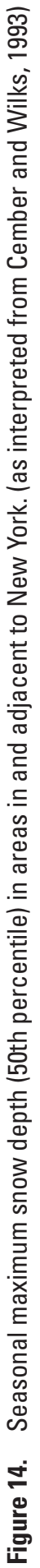


and sampling error (time- and spatial-sampling errors). The regression error cannot be decreased through additional data collection, whereas the sampling error can (through extended operation of existing stations or installation of new stations, or some combination of both).

The GLS regression analysis used in this study entailed logarithmic (base 10) transformations of the streamflow (annual peak discharges) and basin characteristics to obtain a constant variance of the residuals about the regression line, and to linearize the relation between the response variable (peak-discharge) and explanatory variables (basin characteristics) for linear least-squares regression procedures. The multiple-regression equations based on logarithmic transformation of the variables are of the form:

$\log _{10} Y=b_{0}+b_{1} \log _{10} X_{1}+b_{2} \log _{10} X_{2}+\ldots . .+b_{n} \log _{10} X_{n},(1)$

or, after taking antilogs:

$$
Y=10^{b_{0}}\left(X_{1}^{b_{1}}\right)\left(X_{2}^{b_{2}}\right) \ldots . .\left(X_{n}^{b_{n}}\right),
$$

where

$$
\begin{aligned}
Y= & \text { response variable (peak-discharge for } \\
& \text { selected recurrence interval) } \\
b_{0} \text { to } b_{n} \quad= & \text { regression model coefficients estimated } \\
& \text { through GLS procedures, }
\end{aligned}
$$

and

$X_{1}$ to $X_{n} \quad=$ explanatory variables (basin characteristics).

Selection of final explanatory variables for each equation was based on stepwise regression algorithms and all-possible-subsets regression (SAS Institute, 1982). Final regression equations were selected on the basis of several factors, including: standard error of the estimate, Mallow's Cp statistic, statistical significance of the explanatory variables, $r^{2}$ (coefficient of determination), ease of measurement of explanatory variables, and the PRESS statistic (an index of the prediction error associated with the regression equation). Multicollinearity in the regression models was assessed by the variance inflation factor (VIF) and the correlation between explanatory variables.

\section{Regionalization of Flood-Frequency Estimates}

Regression analysis provides a means of relating peak discharge to basin characteristics. Variability of the relation between peak discharge and basin characteristics among gaged sites can be reduced by regionalization, a process in which an area is divided into hydrologic regions to account for regional differences in peak-discharge response and in topographic and climatic variables that affect streamflow. Hydrologic regions refer to areas in which streamflow-gaging stations indicate a similarity of peak-discharge response that differs from the peak-discharge response in adjacent regions. These similarities and differences are defined by the regression residuals, which are the differences between the peak discharges calculated from station records (log-Pearson type III estimates) and the values computed through the regression equations.

\section{Delineation of Hydrologic Regions}

The initial step in delineating hydrologic regions was to develop a statewide regression equation through OLS method. The response variable was the 50-year peak discharge, and the five most significant explanatory variables for the statewide equation were found to be drainage area, main-channel slope, basin storage, mean annual runoff, and water equivalent of snow cover.

Six hydrologic regions within New York were identified and delineated primarily through inspection of the areal distribution of the statewide regression residuals. Areas where the regression equation consistently overestimated or underestimated the peak-discharge response were delineated as discrete hydrologic regions, and separate GLS regression equations were developed to estimate peak-discharge frequencies for each region. Regional differences in geologic and physiographic conditions were also considered during the delineation; generally, the hydrologic-region boundaries were delineated to coincide with drainage-basin divides and are shown in figure 2.

The distribution of regression residuals for each hydrologic region before and after regionalization is shown in box plots in figures $15 \mathrm{~A}$ and $15 \mathrm{~B}$, respectively. The upper plot (fig. 15A) depicts the clustering of residuals within the final six hydrologic regions before regionalization; the lower plot (fig. 15B) shows the distribution of the final GLS regression residuals for the six hydrologic regions after regionalization. The 50-year peak-discharge was the response variable. Comparison of the two plots shows the regression residuals after regionalization to have a smaller range, as well as median values at or near zero.

A further evaluation of the hydrologic region delineations used statistical tests to compare residuals among the six regions; the results indicated a normal distribution of residuals within each of the six regions. Multiple comparison tests were then used to identify which regions' means differed statistically from the other regions' mean. The six regions sample sizes were unequal, ranging from 39 in Region 3 to 109 in Region 1; therefore, two simultaneous inference methods (SIM)—Fisher's Least Significant Difference (LSD) test (t-tests) and Tukey's multiple comparison test-were used (Helsel and Hirsch, 1992). Both tests yielded the following comparisons of means of residuals among the six hydrologic regions:

for adjacent regions $1=2<3>4<5>6<1>4=6<1<3$.

A few adjacent regions had mean residuals that did not differ statistically from each other (the regional residuals shown above that are statistically equal), but other factors, such as topography, geology, climate, and hydrologic judgment, indicate that delineation of these areas as separate hydrologic regions is justified. 


\section{A. BEFORE REGIONALIZATION}

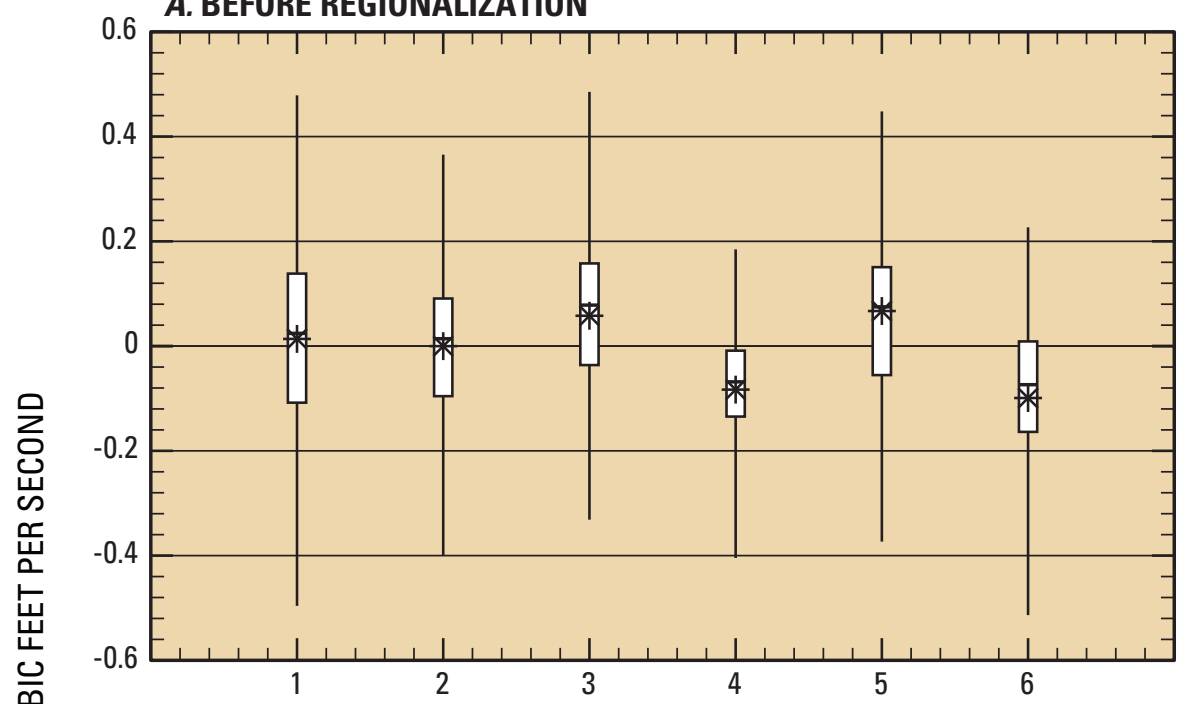

B. AFTER REGIONALIZATION

\section{EXPLANATION}

Largest value
75th percentile
Median (50th percentile)
25th percentile
Smallest value

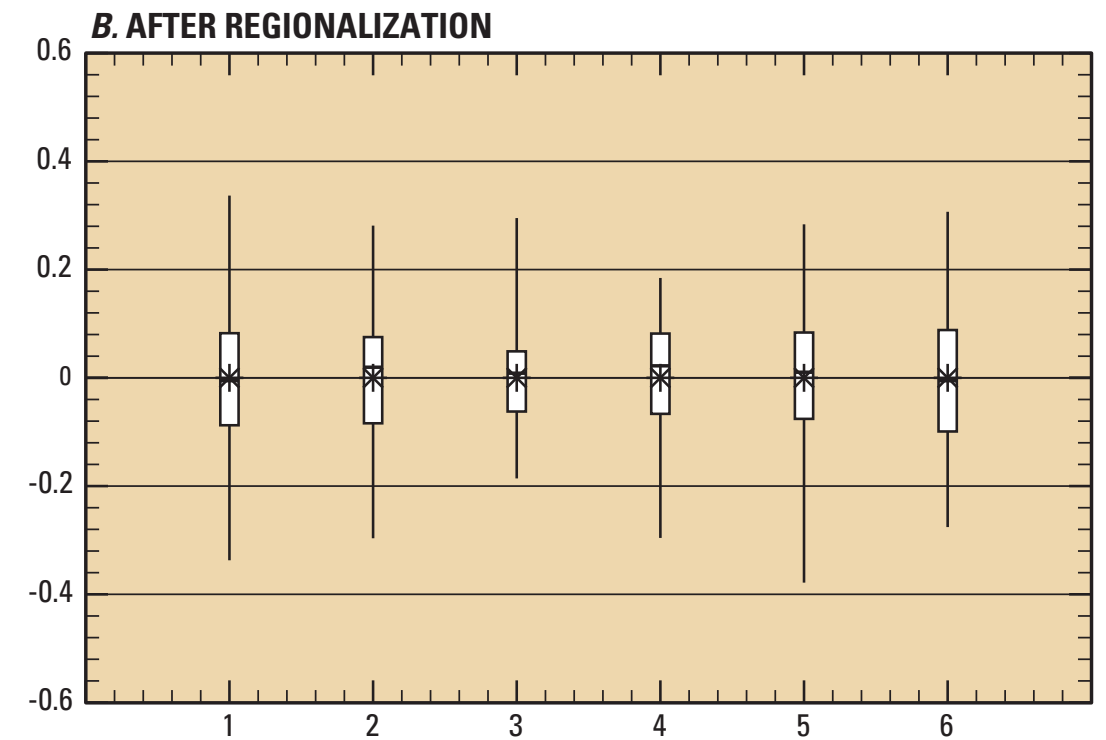

HYDROLOGIC REGION

Figure 15. Boxplots of 50-year peak-discharge residuals from the statewide regression for streamflow-gaging stations within six hydrologic regions of New York, before and after regionalization. (Region boundaries are shown in figure 2).

\section{Regional Basin and Peak-Discharge Characteristics}

Basin and peak-discharge characteristics were compared among regions to summarize and evaluate their differences (figs. 16-17). The range and distribution of values for the 14 basin characteristics are plotted by region in figure 16; the range and distribution of seven peak-discharge statistics are plotted by region in figure 17 . The data in figure 16 indicate that the basins with the greatest main channel slopes, greatest average basin slopes, and greatest mean annual runoff are in Region 3 (Catskill Mountains) (figs. 16C, F, L); those with the greatest basin-storage values are in regions 1 (northern New
York) and 2 (lower Hudson River Valley) (fig. 16J). Basins with the greatest snow depth are in Region 1 (fig. 16N).

The statistics for annual peak discharges (fig. 17) indicate that basins with the greatest means and standard deviations are in hydrologic regions 3 and 2, respectively (figs. 17A, 17B), and those with the greatest 50- and 1.5-year peak-discharge runoff rates are in Region 3 (fig. 17E, 17F). Basins with the greatest median number of years of annual peak-discharge record are within Region 4 (upper Susquehanna River basin area), whereas those with the lowest are in Region 6 (area south of Lake Ontario) (fig. 17G).

The distribution of gaging stations, by length of period of annual peak-discharge record, is plotted in figure 18A, 

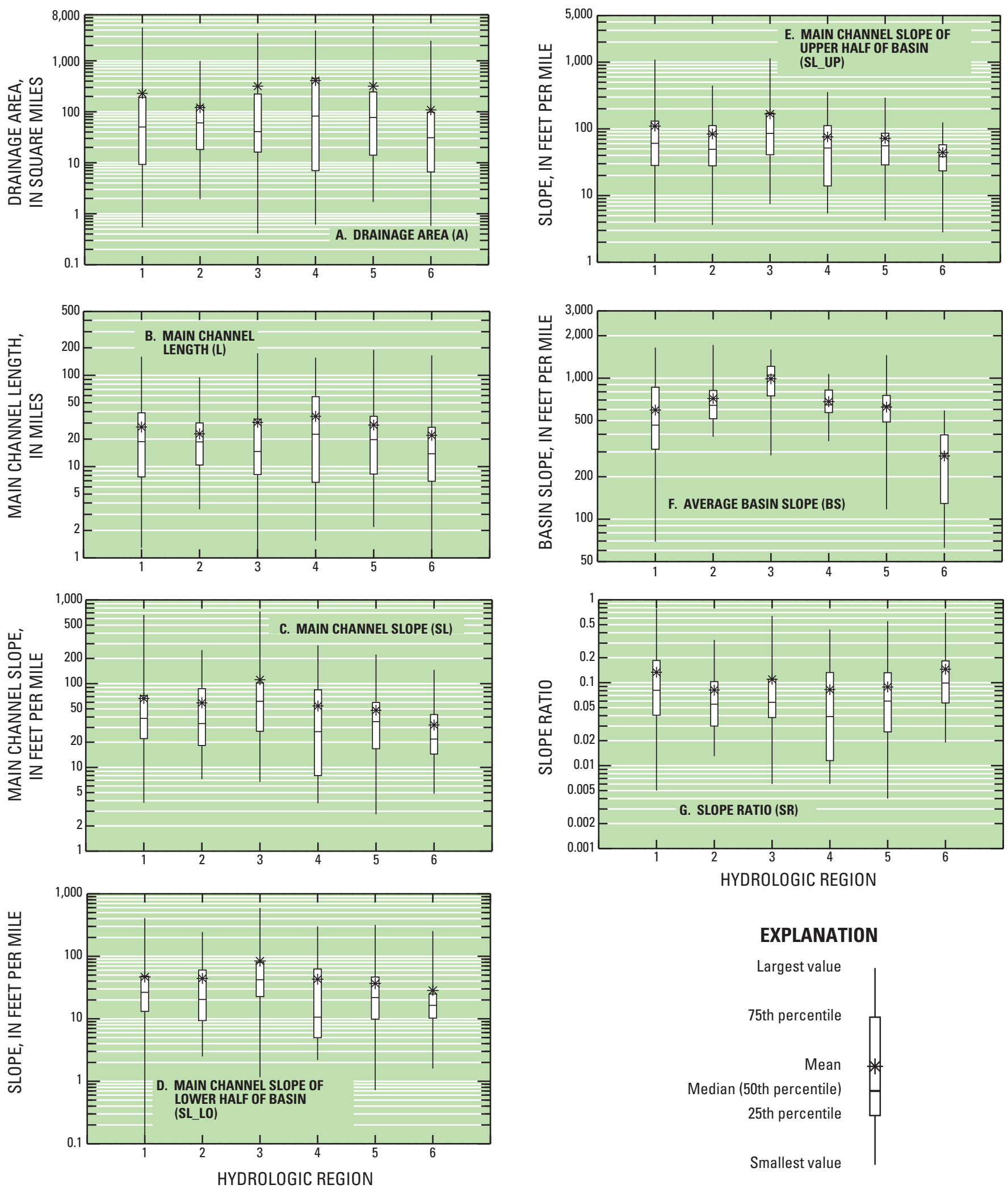

\section{EXPLANATION}

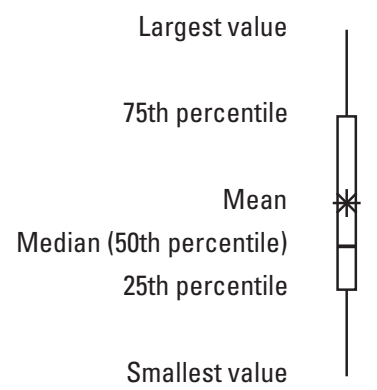

Figure 16. Boxplots of selected basin characteristics for streamflow-gaging stations within six hydrologic regions of New York. (Region boundaries are shown in figure 2). 

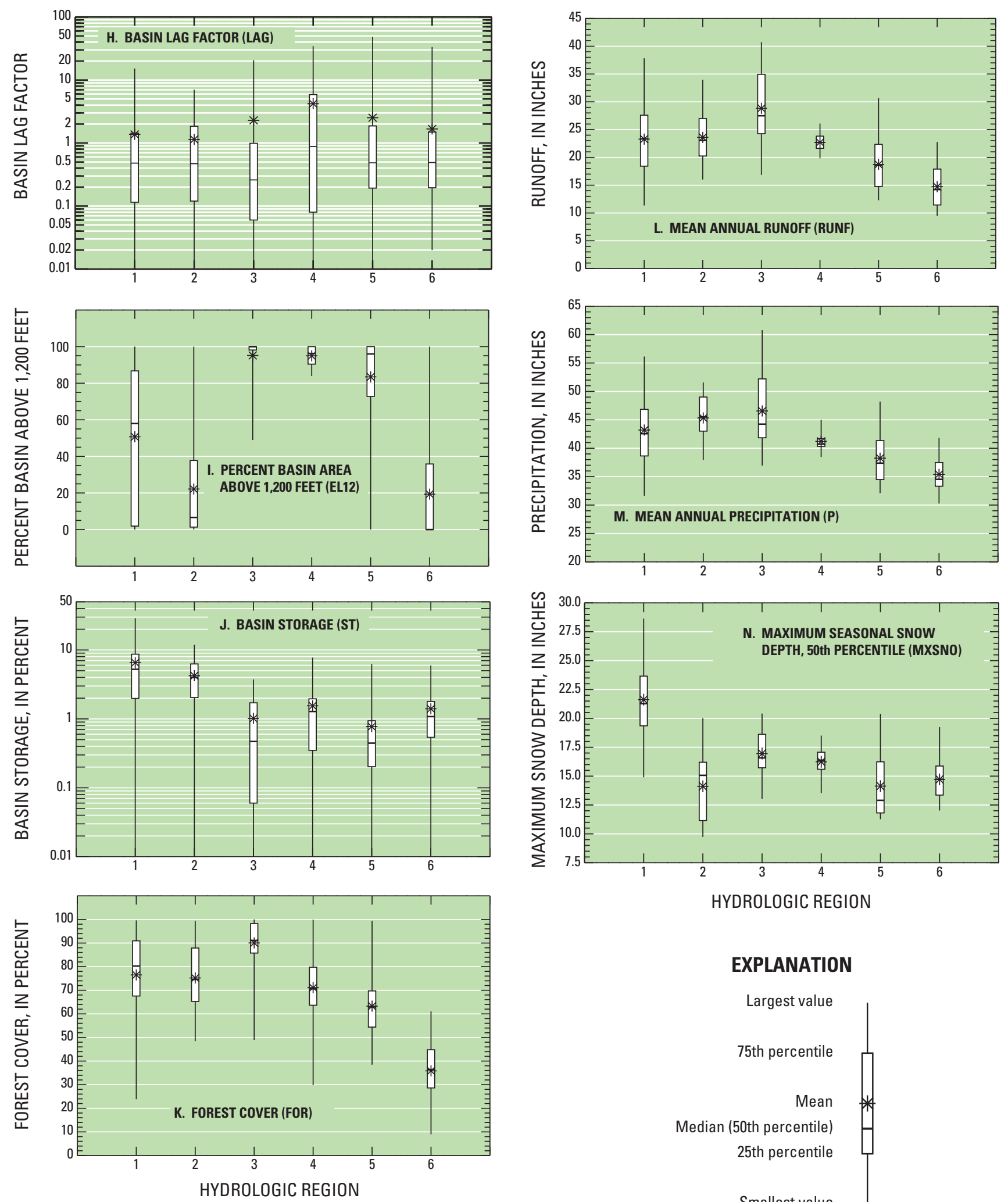

\section{EXPLANATION}

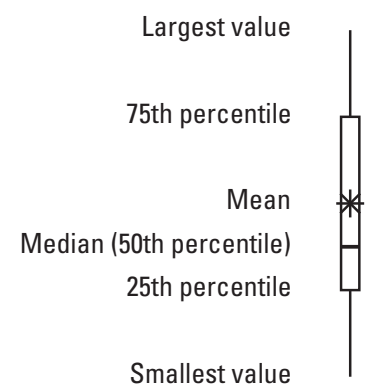

Figure 16. Boxplots of selected basin characteristics for streamflow-gaging stations within six hydrologic regions of New York. (Region boundaries are shown in figure 2).-Continued 

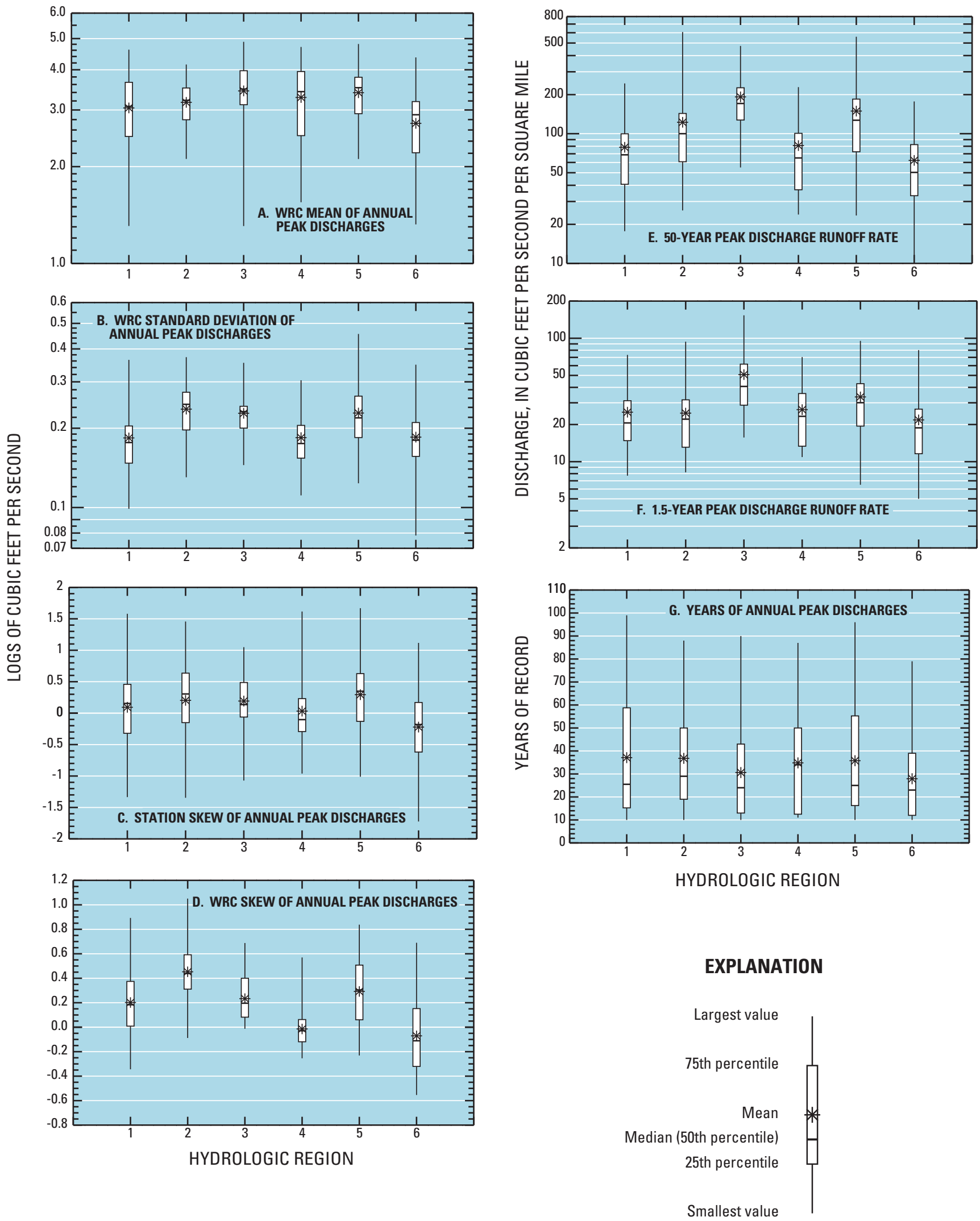

Figure 17. Boxplots of selected peak-discharge characteristics for streamflow-gaging stations within six hydrologic regions of New York. (WRC data represents computations based on Water Resources Council guidelines of 1981). (Region boundaries are shown in figure 2). 
which indicates that the region with the most stations with a record greater than 55 years is Region 1, and the region with the fewest is Region 6. The distribution of gaging stations by size of drainage area is plotted in figure $18 \mathrm{~B}$; the region with the greatest number of stations with small drainage areas (less than $5 \mathrm{mi}^{2}$ ), is Region 1 , and the one with the smallest number of large basins (>200 $\mathrm{mi}^{2}$ ) is Region 6 .

A comparison of the monthly frequency of annual peak discharges in each hydrologic region, and for all stations combined, was made to provide an indication of flood seasonality (fig. 19). Results indicate that most annual peak discharges in every hydrologic region occur in March and April (fig. 19A), as do those in all drainage areas, regardless of size (fig. 19B).

\section{Regional Regression Equations}

Regression equations were developed for each of the six hydrologic regions from (1) all 14 statistically significant explanatory variables (full regression equations) and (2) drainage area only. GLS procedures were used for all regional-regression analyses.

\section{Full-Regression Equations}

The multiple-variable regression equations developed through GLS procedures were used to estimate peak discharges for 10 recurrence intervals $(1.25,1.5,2,5,10,25$, $50,100,200$, and 500 years) in each of the six hydrologic regions and are presented in table 1. Estimates of the standard error of prediction and equivalent years of record for each of these regression equations (Hardison, 1971) are given in table 2, which includes similar data for the drainage-area-only equations (given in table 3 ). The prediction error indicates the expected accuracy of the regression equations when applied to ungaged sites not used in the regression analyses. The standard errors of prediction for the six hydrologic regions range from 14.1 percent (Region 3) to 42.6 percent (Region 5). Peakdischarge estimates for ungaged sites are expected to be within one standard error (of prediction) of the true value about 68 percent of the time. An additional measure of the predictive ability of the equations is the equivalent years of record (table 2 ), which is a function of three factors - the average variability and skew of the annual peak-discharges at sites in a hydrologic region, the accuracy of the regression equation, and the recurrence interval in question (Tasker and Stedinger, 1989). Equivalent years of record represent the number of years of gage data needed to achieve results with accuracy comparable to that given by the regression equations. Regression estimates used to compute peak discharges at gaged sites and at ungaged sites near gaged sites are weighted by the equivalent years of record for the equation. (See section "Computation of Peak Discharge," p. 35.)

Several of the explanatory variables in the full-regression equations (table 1 ) require addition or subtraction of constants before the equation is applied. These constants were identified through sensitivity analyses, normality of the distribution of a variable within its region, improvement in standard error of estimate, coefficient of determination $\left(r^{2}\right)$, and the PRESS statistic (an index for prediction error).

\section{Drainage-Area-Only Equations}

Alternative GLS regression equations that contain only the most significant basin characteristic (drainage area) were developed for each of the six hydrologic regions. These equations (table 3 ) have higher standard errors than the GLS full-regression equations (table 2).

The purpose of drainage-area-only equations (table 3 ) is to obtain estimates of peak discharges more easily (although less accurately) than those obtained by the full equations. The drainage-area-only equations exponents for each region (table 3 ) can be useful in transferring peak-discharge information upstream or downstream from a gaged site according to the ratio of the ungaged sites drainage area to the gaged sites drainage area, raised to the exponent power (Wandle, 1983). 

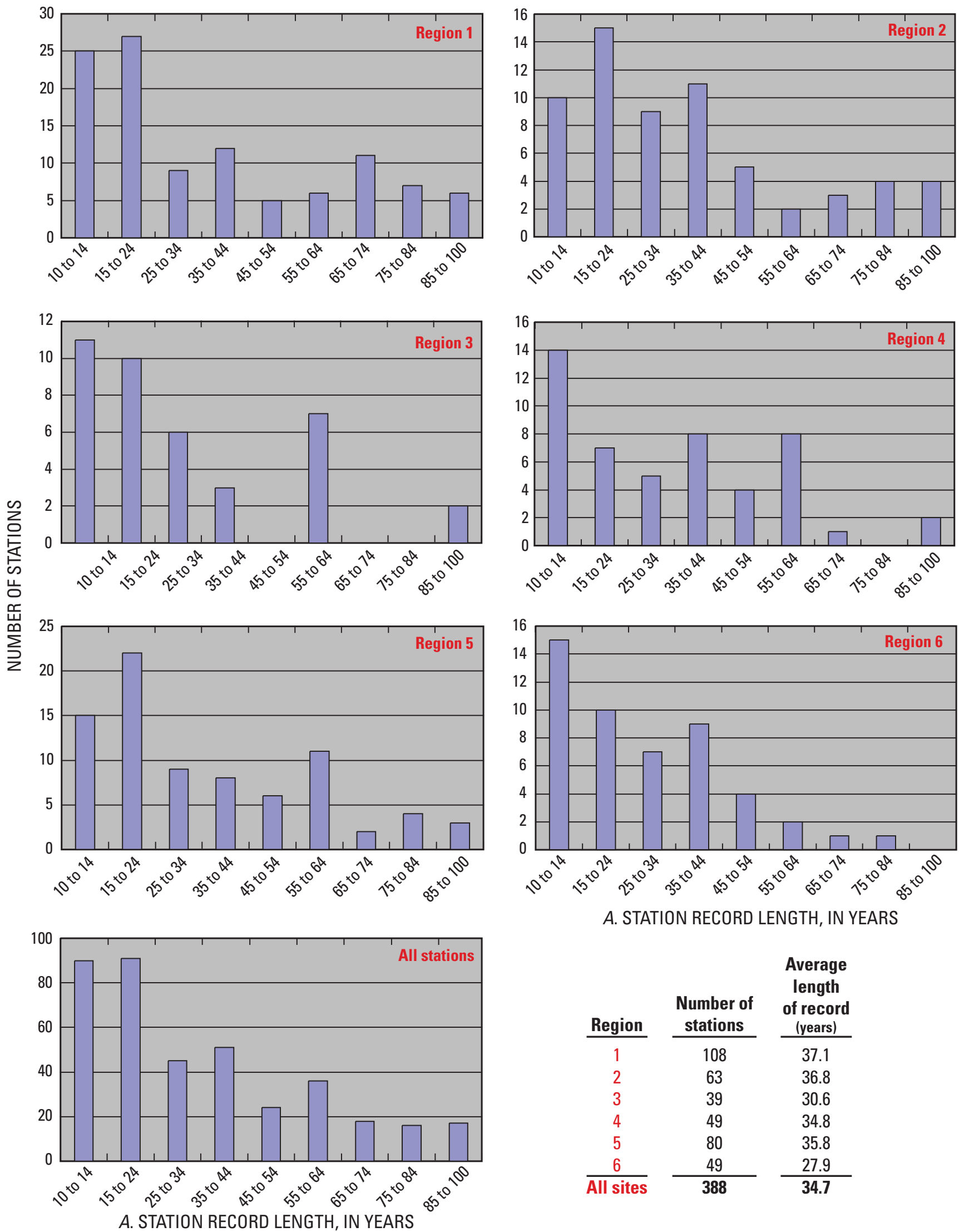

A. STATION RECORD LENGTH, IN YEARS

\begin{tabular}{|c|c|c|}
\hline Region & $\begin{array}{c}\text { Number of } \\
\text { stations } \\
\end{array}$ & $\begin{array}{c}\text { Average } \\
\text { length } \\
\text { of record } \\
\text { (years) } \\
\end{array}$ \\
\hline 1 & 108 & 37.1 \\
\hline 2 & 63 & 36.8 \\
\hline 3 & 39 & 30.6 \\
\hline 4 & 49 & 34.8 \\
\hline 5 & 80 & 35.8 \\
\hline 6 & 49 & 27.9 \\
\hline$\overline{\text { All sites }}$ & 388 & 34.7 \\
\hline
\end{tabular}

Figure 18. Distribution of streamflow-gaging stations within each of six hydrologic regions of New York and for all stations combined by $(A)$ length of record, and $(B)$ drainage-basin size. (Region boundaries are shown in figure 2). 

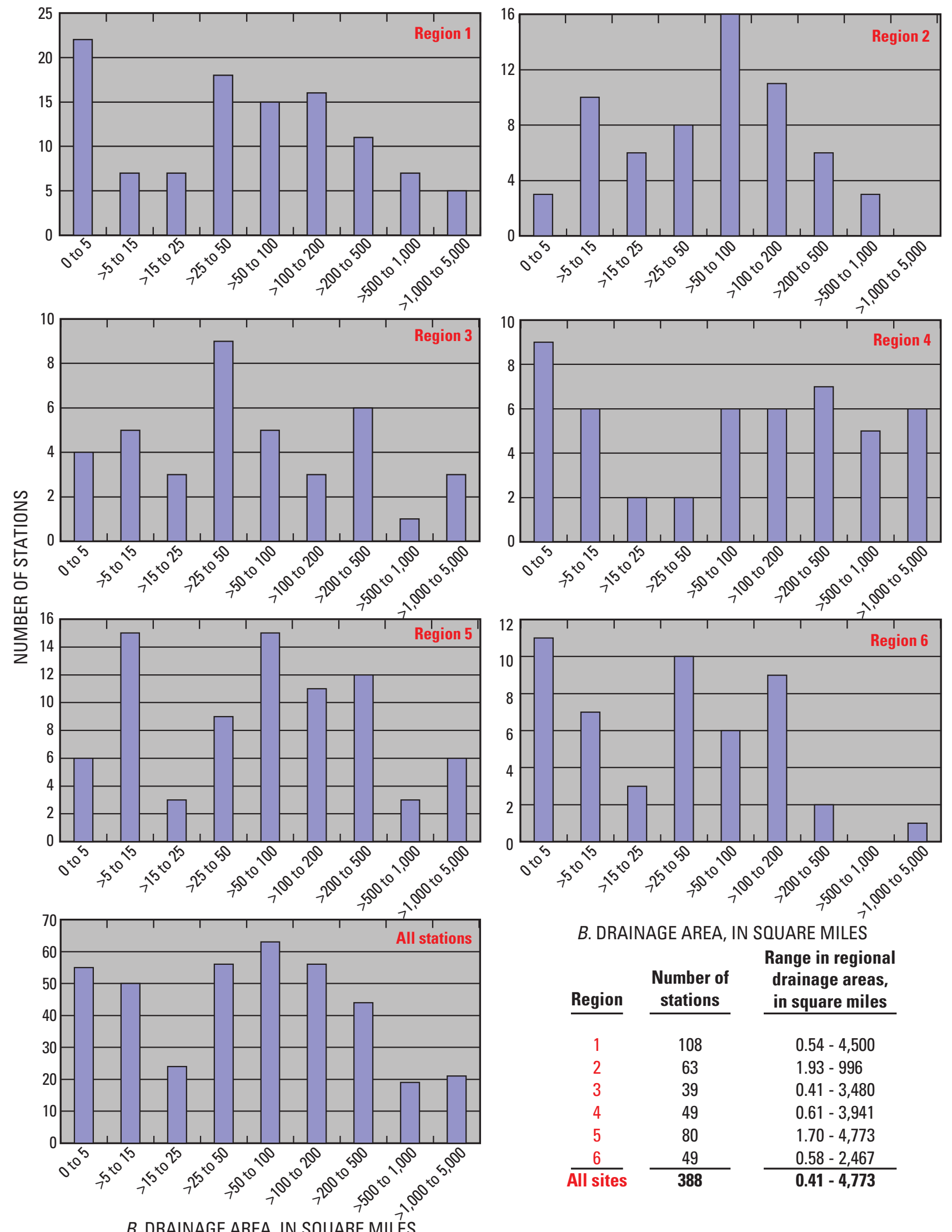

B. DRAINAGE AREA, IN SQUARE MILES

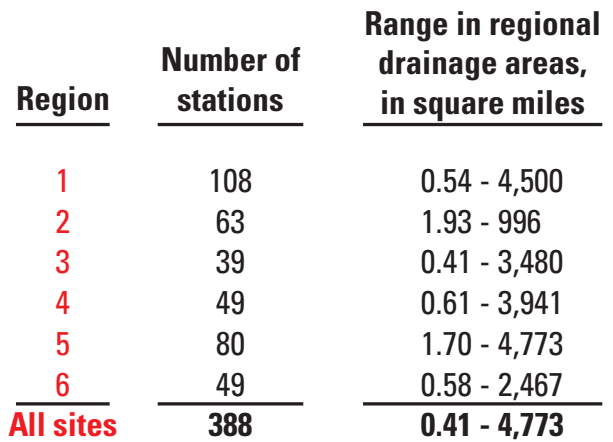

Figure 18. Distribution of streamflow-gaging stations within each of six hydrologic regions of New York and for all stations combined by $(A)$ length of record, and $(B)$ drainage-basin size. (Region boundaries are shown in figure 2).-Continued 


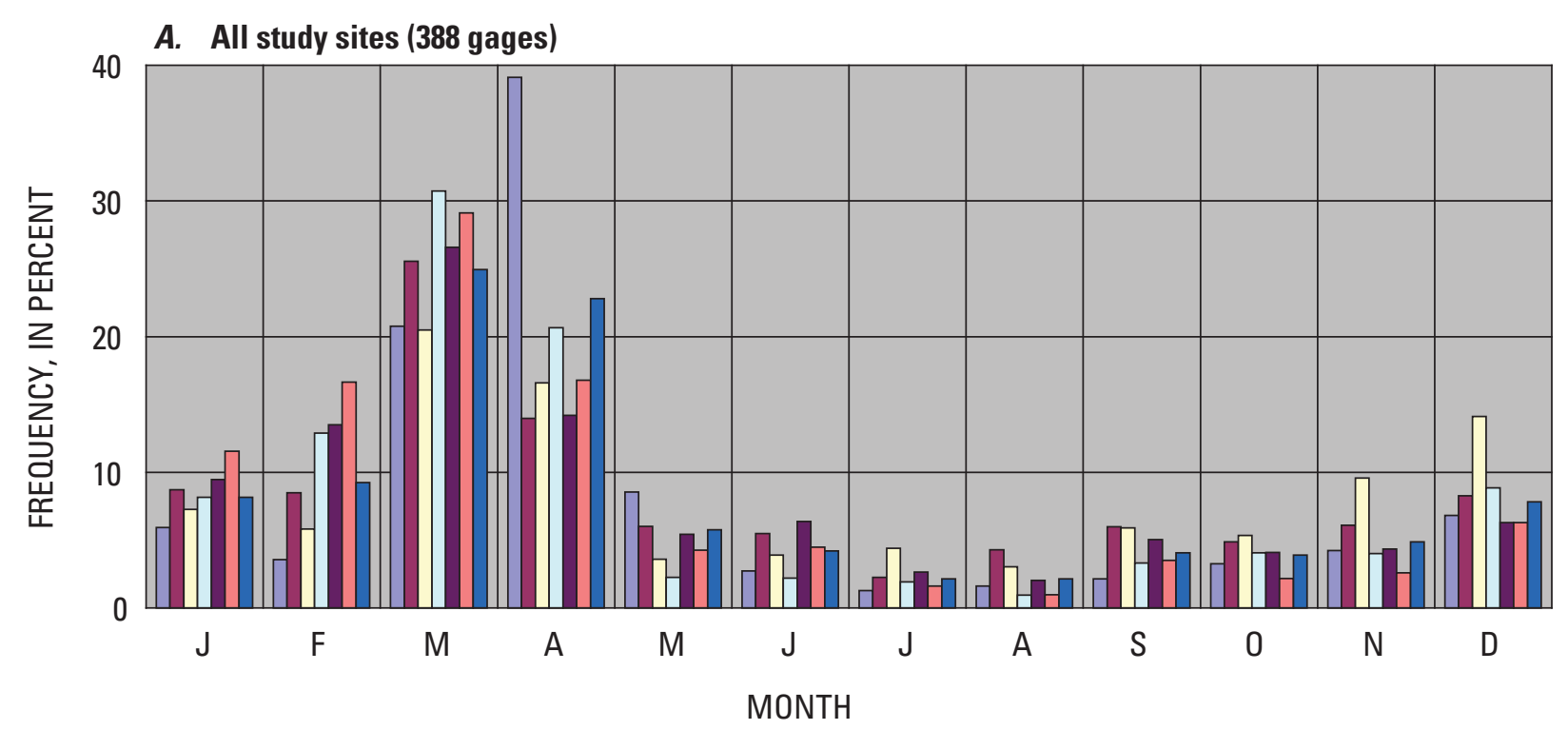

B. Small drainage areas (79 gages)

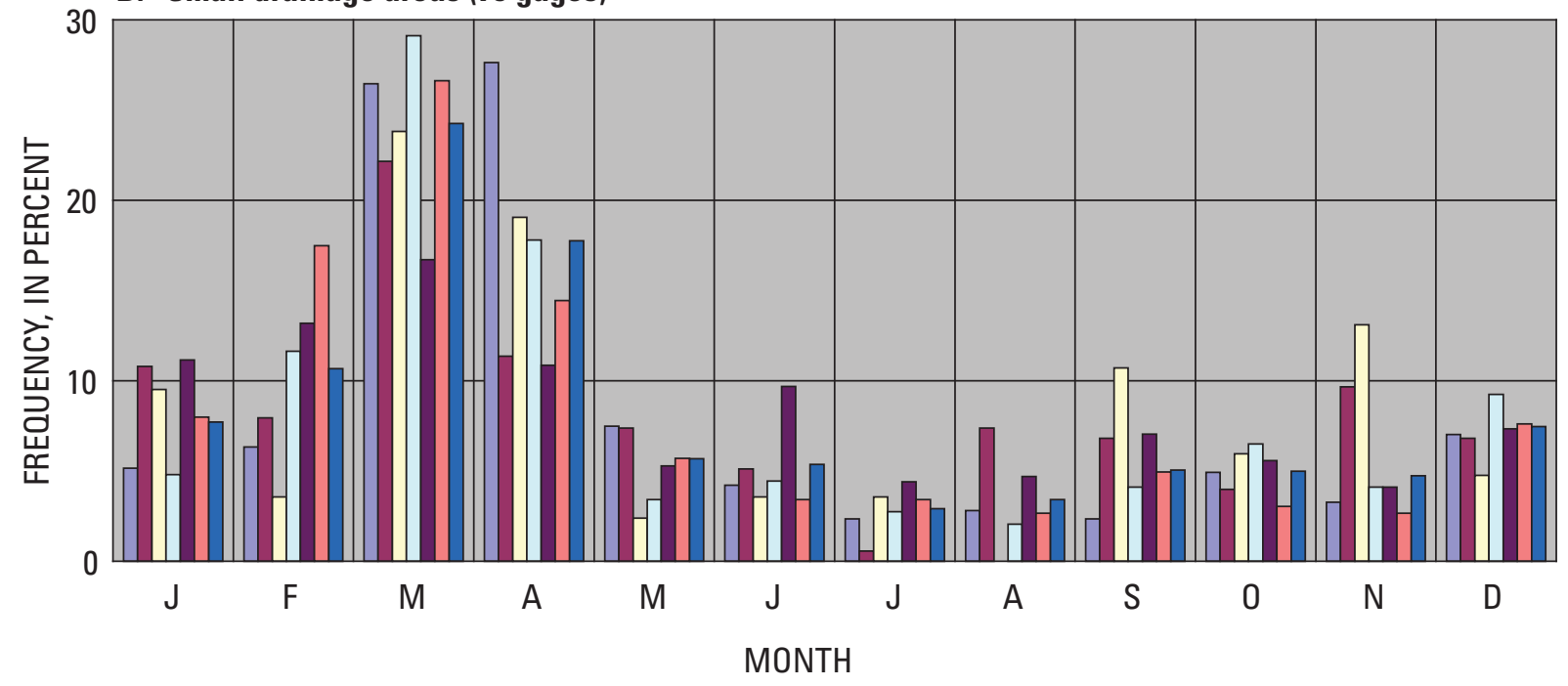

\section{EXPLANATION}

$\begin{array}{ll}\square \text { Region 1 } & \square \text { Region 5 } \\ \square \text { Region 2 } & \square \text { Region 6 } \\ \square \text { Region 3 } & \square \text { New York } \\ \square \text { Region 4 } & \end{array}$

Figure 19. Monthly frequency of annual peak flows within each of six hydrologic regions of New York and for all streamflow-gaging stations combined for $(A)$ all 388 study basins, and $(B) 79$ streams in small (less than 10 square miles) basins. (Region boundaries are shown in figure 2). 
Table 1. Full-regression equations for estimating peak discharges for rural, unregulated streams in each of six hydrologic regions of New York, excluding Long Island.

[A, drainage area, in square miles; ST, basin storage, in percent; $\mathrm{P}$, mean annual precipitation, in inches; LAG, basin lag factor; FOR, basin forested area, in percent; RUNF, mean annual runoff, in inches; MXSNO, seasonal maximum snow depth, $50^{\text {th }}$ percentile, in inches; SR, slope ratio; SL, main channel slope, in feet per mile; EL12, percent of basin above 1,200 feet; Q, flow. subscript is recurrence interval; thus, $\mathrm{Q}_{2}$ refers to discharge with 2-year recurrence interval]

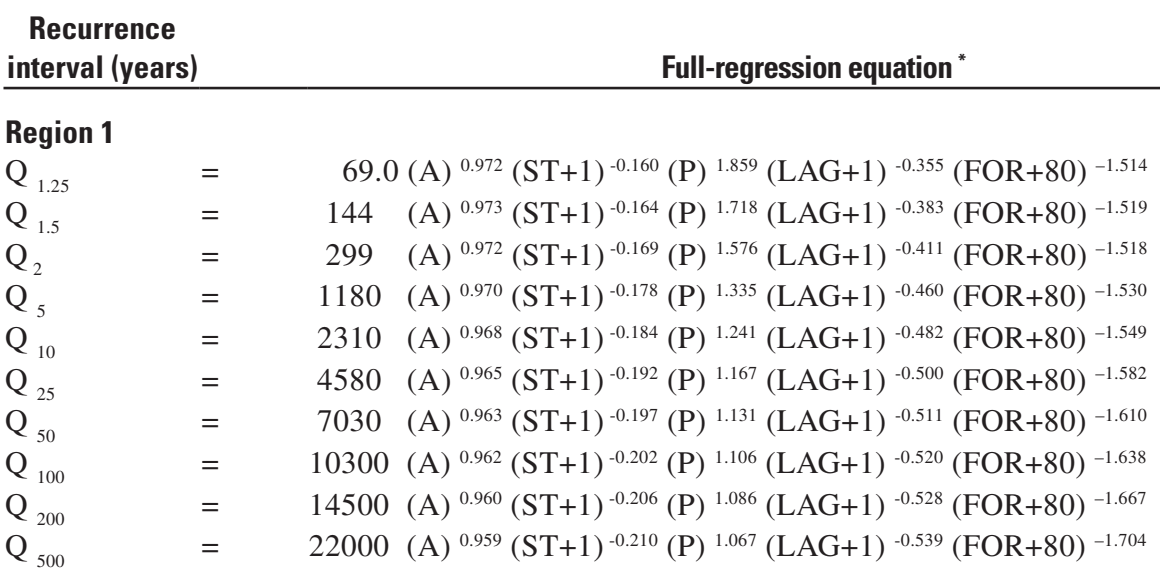

\section{Region 2}


Table 1. Full-regression equations for estimating peak discharges for rural, unregulated streams in each of six hydrologic regions of New York, excluding Long Island.-Continued

[ A, drainage area, in $\mathrm{mi}^{2}$; $\mathrm{ST}$, basin storage, in percent; $\mathrm{P}$, mean annual precipitation, in inches; LAG, basin lag factor; FOR, basin forested area, in percent; RUNF, mean annual runoff, in inches; MXSNO, seasonal maximum snow depth, $50^{\text {th }}$ percentile, in inches; SR, slope ratio; SL, main channel slope, in $\mathrm{ft} / \mathrm{mi}$; EL12, percent of basin above 1,200 ft; Q, flow. subscript is recurrence interval; thus, $\mathrm{Q}_{2}$ refers to discharge with 2-year recurrence interval]

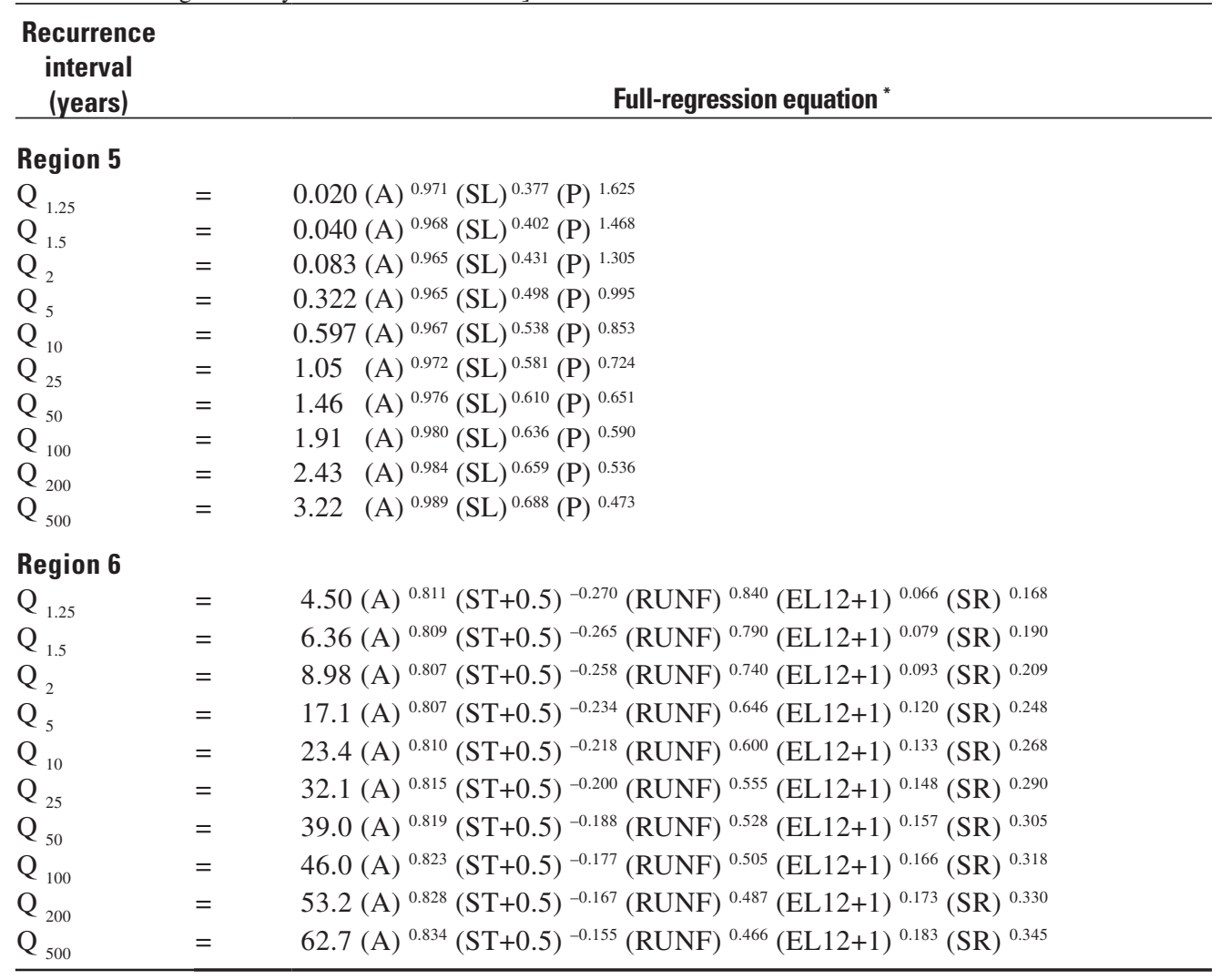

* A -- Drainage area, in square miles. Area of basin upstream from gaging station or site of interest.

L -- Main-channel stream length, in miles. Longest distance from gaging station or site of interest to top of basin.

SL -- Main-channel slope, in feet per mile. Difference in elevation (feet) between points 10 percent and 85 percent of the distance along main stream channel, from the gage or site of interest to the top of the basin, divided by distance (miles) between the two points.

SL_LO -- Slope of lower half of main channel, in feet per mile. Difference in elevation (feet) between points 10 percent and 85 percent of distance along lower half of main channel from gage or point of interest to midpoint of entire main channel, divided by distance (miles) between the two points.

SL_UP -- Slope of upper half of main channel, in feet per mile. Difference in elevation (feet) between points 10 percent and 85 percent of distance along upper half of main channel from midpoint of the entire main channel to the top of the basin, divided by distance (miles) between the two points.

BS -- Average basin slope, in feet per mile. Measured by contour-band method within contributing drainage area and equal to [(total length of all selected elevation contours) (contour interval)] / A .

SR -- Slope ratio. Ratio of main-channel slope to basin slope within the drainage basin, computed as SL / BS .

LAG -- Basin lag factor. Calculated as L / $\left[\left(\mathrm{SL} \_\mathrm{UP}+1\right)\left(\mathrm{SL} \_\mathrm{LO}+1\right)\right]^{0.5}$.

EL12 -- Percentage of drainage basin at or greater than 1,200 feet above sea level.

ST -- Basin storage. Percentage of total drainage area shown as lakes, ponds, and swamps (wetlands) as interpreted from National Land Cover Dataset (NLCD) land-use data (U.S. Geological Survey, 2000).

FOR -- Basin forested area. Percentage of total drainage area shown as forest cover, as interpreted from NLCD land-use data (U.S. Geological Survey, 2000).

RUNF -- Mean annual runoff, in inches. (from Randall, 1996). 
Table 2. Standard errors of prediction and equivalent years of record for full regression equations and drainage-area-only regression equations, for six hydrologic regions of New York, excluding Long Island.

[SE, standard error of prediction. Region boundaries are shown in figure 2; regression equations are given in tables 1 and 3]

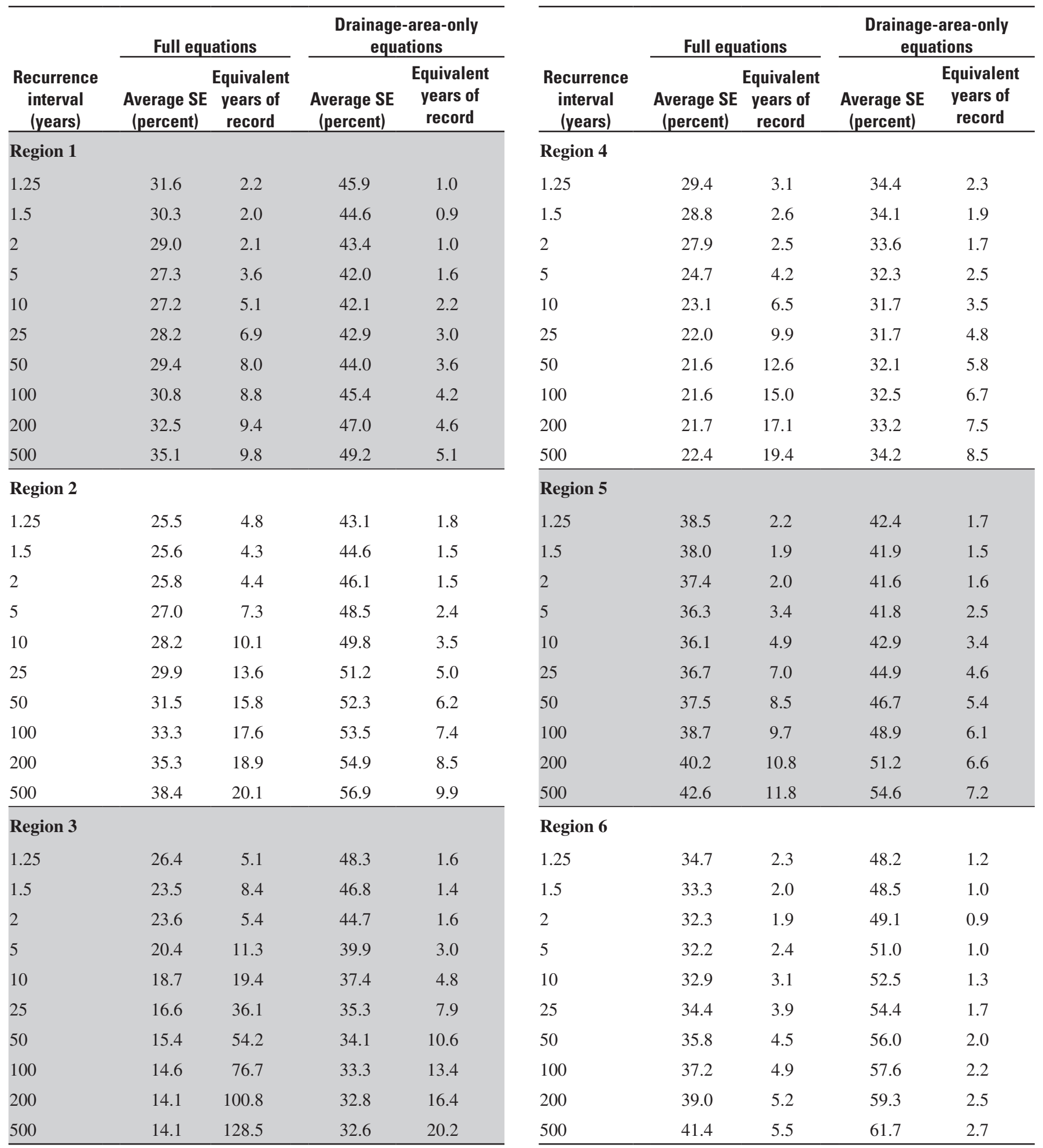


Table 3. Regression equations based on drainage area only for estimating peak discharges for rural, unregulated streams in each of six hydrologic regions of New York, excluding Long Island.

[Corresponding full equations are given in table 1. Region boundaries are shown in figure 2. A, drainage area; Q, flow. Subscript is recurrence interval; thus, $\mathrm{Q}_{2}$ refers to discharge with 2-year recurrence interval]

\begin{tabular}{|c|c|c|c|c|c|c|c|c|}
\hline \multicolumn{3}{|c|}{ Region 1} & \multicolumn{3}{|c|}{ Region 2} & \multicolumn{3}{|c|}{ Region 3} \\
\hline$Q_{1.25}$ & $=$ & 31.7 (A) ${ }^{0.857}$ & $Q_{1.25}$ & $=$ & 43.4 (A) ${ }^{0.772}$ & $Q_{1.25}$ & $=$ & $57.4(\mathrm{~A})^{0.861}$ \\
\hline $\mathrm{Q}_{1.5}$ & $=$ & $38.5(\mathrm{~A})^{0.848}$ & $Q_{1.5}$ & $=$ & $56.1(\mathrm{~A})^{0.758}$ & $\mathrm{Q}_{1.5}$ & $=$ & $71.8(\mathrm{~A})^{0.857}$ \\
\hline $\mathrm{Q}_{2}$ & $=$ & $47.6(\mathrm{~A})^{0.839}$ & $\mathrm{Q}_{2}$ & $=$ & 74.7 (A) ${ }^{0.743}$ & $\mathrm{Q}_{2}$ & $=$ & $90.8(\mathrm{~A})^{0.853}$ \\
\hline $\mathrm{Q}_{5}$ & $=$ & $73.0(\mathrm{~A})^{0.822}$ & $\mathrm{Q}_{5}$ & $=$ & 139 (A) 0.712 & $\mathrm{Q}_{5}$ & $=$ & $144(\mathrm{~A})^{0.850}$ \\
\hline Q 10 & $=$ & $92.1(\mathrm{~A})^{0.813}$ & $Q_{10}$ & $=$ & $197(\mathrm{~A})^{0.695}$ & $\mathrm{Q}_{10}$ & $=$ & $185(\mathrm{~A})^{0.848}$ \\
\hline$Q_{25}$ & $=$ & $119(\mathrm{~A})^{0.802}$ & $Q_{25}$ & $=$ & $291(\mathrm{~A})^{0.677}$ & $Q_{25}$ & $=$ & 249 (A) ${ }^{0.843}$ \\
\hline $\mathrm{Q}_{50}$ & $=$ & $140(\mathrm{~A})^{0.796}$ & $Q_{50}$ & $=$ & $378(\mathrm{~A})^{0.666}$ & $\mathrm{Q}_{50}$ & $=$ & 304 (A) ${ }^{0.840}$ \\
\hline$Q_{100}$ & $=$ & $162(\mathrm{~A})^{0.790}$ & $Q_{100}$ & $=$ & $480(\mathrm{~A})^{0.656}$ & $Q_{100}$ & $=$ & 367 (A) ${ }^{0.836}$ \\
\hline $\mathrm{Q}_{200}$ & $=$ & 186 (A) $)^{0.785}$ & $\mathrm{Q}_{200}$ & $=$ & $598(\mathrm{~A})^{0.648}$ & $\mathrm{Q}_{200}$ & $=$ & 436 (A) ${ }^{0.832}$ \\
\hline $\mathrm{Q}_{500}$ & $=$ & $219(\mathrm{~A})^{0.779}$ & $Q_{500}$ & $=$ & $782(\mathrm{~A})^{0.638}$ & $\mathrm{Q}_{500}$ & $=$ & $539(\mathrm{~A})^{0.827}$ \\
\hline \multicolumn{3}{|c|}{ Region 4} & \multicolumn{3}{|c|}{ Region 5} & \multicolumn{3}{|c|}{ Region 6} \\
\hline $\mathrm{Q}_{1.25}$ & $=$ & 39.1 (A) ${ }^{0.833}$ & $Q_{1.25}$ & $=$ & $54.8(\mathrm{~A})^{0.800}$ & $\mathrm{Q}_{1.25}$ & $=$ & 31.1 (A) ${ }^{0.783}$ \\
\hline $\mathrm{Q}_{1.5}$ & $=$ & 48.7 (A) ${ }^{0.823}$ & $Q_{1.5}$ & $=$ & 71.5 (A) ${ }^{0.785}$ & $\mathrm{Q}_{1.5}$ & $=$ & $37.2(\mathrm{~A})^{0.782}$ \\
\hline $\mathrm{Q}_{2}$ & $=$ & $61.3(\mathrm{~A})^{0.812}$ & $\mathrm{Q}_{2}$ & $=$ & $95.4(\mathrm{~A})^{0.770}$ & $\mathrm{Q}_{2}$ & $=$ & $44.5(\mathrm{~A})^{0.782}$ \\
\hline $\mathrm{Q}_{5}$ & $=$ & $97.4(\mathrm{~A})^{0.788}$ & $\mathrm{Q}_{5}$ & $=$ & $172(\mathrm{~A})^{0.738}$ & $\mathrm{Q}_{5}$ & $=$ & $62.7(\mathrm{~A})^{0.788}$ \\
\hline $\mathrm{Q}_{10}$ & $=$ & $124(\mathrm{~A})^{0.775}$ & $Q_{10}$ & $=$ & 237 (A) ${ }^{0.722}$ & $\mathrm{Q}_{10}$ & $=$ & 74.2 (A) ${ }^{0.794}$ \\
\hline $\mathrm{Q}_{25}$ & $=$ & $161(\mathrm{~A})^{0.761}$ & $Q_{25}$ & $=$ & 332 (A) ${ }^{0.706}$ & $\mathrm{Q}_{25}$ & $=$ & $88.4(\mathrm{~A})^{0.801}$ \\
\hline $\mathrm{Q}_{50}$ & $=$ & 191 (A) ${ }^{0.751}$ & $Q_{50}$ & $=$ & $412(\mathrm{~A})^{0.695}$ & $\mathrm{Q}_{50}$ & $=$ & $98.5(\mathrm{~A})^{0.807}$ \\
\hline$Q_{100}$ & $=$ & $221(\mathrm{~A})^{0.743}$ & $Q_{100}$ & $=$ & $502(\mathrm{~A})^{0.687}$ & $Q_{100}$ & $=$ & $108(\mathrm{~A})^{0.813}$ \\
\hline $\mathrm{Q}_{200}$ & $=$ & $253(\mathrm{~A})^{0.735}$ & $Q_{200}$ & $=$ & $600(\mathrm{~A})^{0.679}$ & $\mathrm{Q}_{200}$ & $=$ & $117(\mathrm{~A})^{0.818}$ \\
\hline $\mathrm{Q}_{500}$ & $=$ & $298(\mathrm{~A})^{0.727}$ & $Q_{500}$ & $=$ & $745(\mathrm{~A})^{0.670}$ & $\mathrm{Q}_{500}$ & $=$ & $129(\mathrm{~A})^{0.826}$ \\
\hline
\end{tabular}




\section{Computation of Peak Discharge}

Methods for computing a peak discharge estimate for a selected recurrence interval at a specific site depend on whether the site is gaged or ungaged, and whether the drainage area lies within a single hydrologic region or crosses into an adjacent hydrologic region or State. Estimates for gaged and ungaged sites are described below with examples for each method.

\section{Gaged Sites}

The GLS regional-regression equations can be used to improve streamflow-gaging-station estimates (based on log-Pearson type III flood-frequency analysis of the gaged annual peak-discharge record) by using a weighted average of the two estimates (regression and gaged). Incorporating the regression estimate into the weighted average tends to decrease time sampling errors that result for sites with short periods of record. All three estimates - those based on the station record, those derived through regression, and the weighted average for each recurrence interval at each of the 388 streamflow-gaging stations used in this study are given in table 8 (at the end of the report). The weighted-average discharges are generally the most reliable and are computed from the equation:

$$
Q_{T(w)}=\frac{Q_{T(g)}(N)+Q_{T(r)}(E)}{N+E},
$$

where

$Q_{T(w)} \quad$ is weighted peak discharge at the gaged site, in cubic feet per second, for the $T$-year recurrence interval;

$Q_{T(g)} \quad$ is peak discharge at gage, in cubic feet per second, calculated through log-Pearson Type III frequency analysis of the station's peak discharge record, for the $T$-year recurrence interval;

$N \quad$ is number of years of annual peak-discharge record used to calculate $Q_{T(g)}$ at the gaging station;

$Q_{T(r)} \quad$ is regional regression estimate of the peak discharge at the gaged site, in cubic feet per second, for the $T$-year recurrence interval;

and

$E \quad$ is average equivalent years of record associated with the regression equation (table 2) that was used to calculate $Q_{T(r)}$.

\section{Ungaged Sites}

The following methods may be used to estimate peak discharges of selected recurrence intervals for sites on four types of ungaged streams: (1) where the drainage area is within a single hydrologic region; (2) where the drainage area extends into an adjacent hydrologic region or State; (3) where the ungaged site is near a gaged site on the same stream, and (4) where the ungaged site is between two gaged sites on the same stream. Methods for each of these conditions are described below:

1. If the drainage area of an ungaged site lies entirely within a single hydrologic region (fig. 2), peak discharges for selected recurrence intervals are computed from the regression equations for that region (table 1).

2. If the drainage area of an ungaged site extends into an adjacent hydrologic region or state, the percentage that lies within each hydrologic region and (or) state is estimated. Peak-discharge estimates are computed for the entire drainage basin through each of the appropriate regional or State equations, and the drainage-area percentages are used as weighting factors by multiplying the percentages by the corresponding peak-discharge estimate; the resulting values are then summed to compute the peak discharge for the entire basin. Equations for the five adjacent states are given in USGS or State floodfrequency reports for New Jersey (Stankowski, 1974), Pennsylvania (Stuckey and Reed, 2000), Connecticut (Ahearn, 2004), Massachusetts (Wandle, 1983), and Vermont (Olson, 2002).

3. If the ungaged site for which flood-frequency estimates are needed is on a gaged stream, and if the site's drainage area is between 50 and 150 percent of the drainage area of the stream at the gage, the weighted estimate for the ungaged site can be computed by the following equation (Ries and Crouse, 2002):

$$
Q_{T(U) w}=\frac{2 \Delta A}{A_{g}} Q_{T(U) r}+\left(1-\frac{2 \Delta A}{A_{g}}\right) Q_{T(U) g},
$$


where

$Q_{T(U) w} \quad$ is the weighted estimate of discharge $Q_{T}$ for recurrence interval $T$ at the ungaged site, is the absolute value of the difference between the drainage areas of the streamflow-gaging station, $\left(A_{g}\right)$ and the ungaged site,

$\begin{aligned} \Delta A & \left(A_{u}\right),\left|A_{g}-A_{u}\right|, \\ Q_{T(U) r} & \text { is the peak-flow estimate for recurrence interval } T \text { at the ungaged site, derived from the applicable regional }\end{aligned}$ regression equation (table 1),

and

$Q_{T(U) g} \quad$ is the peak-flow estimate for recurrence interval $T$ at the ungaged site, derived from the weighted estimate of peak discharge at the streamflow-gaging station, $Q_{T(w)}$ (see method for gaged sites), by adjusting for the effect of the difference in drainage area between the streamflow-gaging station and the ungaged site.

$Q_{T(U) g}$ is computed as:

$$
Q_{T(U) g}=\left(\frac{A_{u}}{A_{g}}\right)^{b} \cdot Q_{T(w)},
$$

where

depending on the hydrologic region and the recurrence interval $T, b$ is the exponent from the appropriate drainage-area-only equation (table 3 ).

4. If the ungaged site is on a gaged stream, and lies between two gaging stations, the following equation (Hodgkins, 1999) is used:

$$
Q_{T(u f) w}=\left[Q_{T(u 1) w}\left(A_{g 2}-A_{u}\right)+Q_{T(u 2) w}\left(A_{u}-A_{g 1}\right)\right] /\left(A_{g 2}-A_{g 1}\right)
$$

where

$Q_{T(u f) w} \quad$ is final weighted flow estimate for the ungaged site between gaging stations;

$Q_{T(u l) w} \quad$ is the weighted flow estimate computed for the ungaged site from the upstream-gage records as described in method 3 above;

$A_{g 2} \quad$ is the drainage area of the downstream gage;

$A_{u} \quad$ is the drainage area of the ungaged site;

$Q_{T(u 2) w} \quad$ is the weighted flow estimate computed for the ungaged site from the downstream-gage records as described in method 3 above;

and

$A_{g 1} \quad$ is the drainage area of the upstream gage.

\section{Sample Computations}

The following examples illustrate use of the four methods described for ungaged sites to calculate the 50-year peak discharge for a gaged site and three types of ungaged sites. Variables are explained in tables 1 and 3. 
Example 1. Gaged site whose drainage area lies within a single hydrologic region: Estimate the 50-year peak discharge at the gage site on Fishkill Creek at Hopewell Junction, NY (01372800).

Given:

a) Gaged drainage basin is in hydrologic Region 2 (fig. 2);

b) Drainage area $(A)=57.3 \mathrm{mi}^{2}$ (table 10$)$;

c) Area of lakes, ponds, and wetlands [basin storage $(S T)]=4.97$ percent of total drainage area (table 10);

d) Basin lag factor $(L A G)=L /\left[\left(S L \_U P+1\right)\left(S L \_L O+1\right)\right]^{0.5}$;

$S L \_U P=27.53 \mathrm{ft} / \mathrm{mi} ; S L \_L O=12.67 \mathrm{ft} / \mathrm{mi} ; L=21.00 \mathrm{mi}($ table 10$)$,

$L A G=21.00 /[(27.53+1)(12.67+1)]^{0.5}$

$=21.00 / 19.75$

$=1.063$ (table 10);

e) Mean annual runoff $(R U N F)=21.29$ in. (table 10);

f) The 50-year peak-discharge $\left(Q_{50(g)}\right)$ based on the gaged record $=3,600 \mathrm{ft}^{3} / \mathrm{s}$ (table 8);

g) Number of years $(N)$ of systematic annual peak-discharge record used to calculate $\left(Q_{50(g)}\right)=30$ years (table 8$)$.

\section{Solution:}

The 50-year regression estimate $\left(Q_{50(r)}\right)$ for this station is computed from the following equation for hydrologic Region 2 (table 1):

$$
Q_{50(r)}=49.7(A)^{0.902}(S T+5)^{-0.939}(L A G+1)^{-0.441}(R U N F)^{1.068}
$$

From the given values for these four basin characteristics:

$$
\begin{aligned}
Q_{50(r)} & =49.7(57.3)^{0.902}(4.97+5)^{-0.939}(1.063+1)^{-0.441}(21.29)^{1.068} \\
& \left.=4,210 \mathrm{ft}^{3} / \mathrm{s} \text { (also in table } 8\right) .
\end{aligned}
$$

The equivalent years of record (E) for $Q_{50(r)}$ for Region 2 is 15.8 years (table 2). Therefore, the weighted peak-discharge $Q_{50(\mathrm{w})}$ for this station (method for gaged sites) is:

$$
\begin{aligned}
Q_{50(W)} & =\frac{Q_{50(g)}(N)+Q_{50(r)}(E)}{N+E} \\
& =\frac{(3,600)(30)+(4,210)(15.8)}{30+15.8} \\
& \left.=3,810 \mathrm{ft}^{3} / \mathrm{s} \text { (also in table } 8\right) .
\end{aligned}
$$


Example 2. Ungaged site whose drainage area extends into an adjacent hydrologic region or State: Compute the 50-year peakdischarge regression estimate for Genesee River at Rochester (04232000). For this example, assume this site is ungaged and is under pre-regulation conditions.

Given:

a) Drainage area (A) at the site is $2,467 \mathrm{mi}^{2}$, and the site is in hydrologic Region 6 (fig. 2);

b) The upper 53.5 percent $\left(1,321 \mathrm{mi}^{2}\right)$ of the basin is in hydrologic Region 5;

c) Main channel slope $(S L)=8.05 \mathrm{ft} / \mathrm{mi}($ table 10$)$;

d) Mean annual precipitation $=33.92$ in (table 10);

e) Area of lake, ponds, and wetlands [storage $(S T)]=1.08$ percent (table 10);

f) Mean annual runoff $(R U N F)=14.64$ in (table 10);

g) Percentage of the basin above 1,200 ft mean sea level $(E L 12)=58.8$ percent (table 10);

h) Slope ratio $(S R)=\frac{\text { Main channel slope }(S L)}{\text { Average basin slope }(B S)}$

$$
\begin{aligned}
& =\frac{8.05 \mathrm{ft} / \mathrm{mi}(\text { table } 10)}{432.25 \mathrm{ft} / \mathrm{mi}(\text { table } 10)} \\
& =0.019(\text { also in table } 10) .
\end{aligned}
$$

\section{Solution:}

Percentage of total drainage area within hydrologic Region 5 is 53.5 percent, and percentage of total drainage area within hydrologic Region 6 is 46.5 percent. These are the weighting factors to be applied after the 50-year peak-discharges for the site have been computed through regression equations for regions 5 and 6 (table 1):

$$
\begin{aligned}
Q_{50(r)}(\text { Region 5) } & =1.46(A)^{0.976}(S L)^{0.610}(P)^{0.651} \\
& =1.46(2,467)^{0.976}(8.05)^{0.610}(33.92)^{0.651} \\
& =105,700 \mathrm{ft}^{3} / \mathrm{s} ; \\
Q_{50(r)}(\text { Region 6) } & =39.0(A)^{0.819}(S T+0.5)^{-0.188}(R U N F)^{0.528}(E L 12+1)^{0.157}(S R)^{0.305} \\
& =39.0(2,467)^{0.819}(1.08+0.5)^{-0.188}(14.64)^{0.528}(58.8+1)^{0.157}(0.019)^{0.305} \\
& =50,270 \mathrm{ft}^{3} / \mathrm{s} .
\end{aligned}
$$

To compute a final 50-year regression estimate at this station, apply the two drainage-area percentages as weighting factors:

$$
Q_{50(r)}=(105,700)(0.535)+(50,270)(0.465)=79,900 \mathrm{ft}^{3} / \mathrm{s}
$$

The Genesee River station at Rochester (04232000) is currently regulated, and the above information represents preregulation conditions. This example is for illustration purposes only and is not applicable to present conditions at this station. 
Example 3. Ungaged site near a gage site on the same stream. Estimate the 50-year peak-discharge at the ungaged site Normans Kill near Westmere. This example is for illustration purposes only since Normans Kill near Westmere was previously a streamflow-gaging station (01359519).

\section{Given:}

a) This drainage basin is in hydrologic Region 2, upstream from the gaged site of Normans Kill at Albany [station 01359528, drainage area $\left.\left(A_{g}\right)=168 \mathrm{mi}^{2}\right]$;

b) Drainage area $\left(A_{u}\right)$ of ungaged site Normans Kill near Westmere $=131 \mathrm{mi}^{2}$;

c) Area of lakes, ponds, and wetlands [storage $(S T)]=2.39$ percent of basin;

d) Basin lag factor $(L A G)=1.073$;

e) Mean annual runoff $(R U N F)=17.57$ in.

\section{Solution:}

The drainage area of this ungaged site $\left(131 \mathrm{mi}^{2}\right)$ meets the criterion of between 50 and 150 percent of the drainage area at the gaged site $\left(168 \mathrm{mi}^{2}\right)$. Therefore, method 3 (for an ungaged site near a gaged site on the same stream) can be used.

$$
\Delta A=\left|A_{g}-A_{u}\right|=|168-131|=37 \mathrm{mi}^{2}
$$

The 50-year regression estimate $\left(Q_{50(\mathrm{urr})}\right.$ for this ungaged site (Normans Kill near Westmere) is:

$$
\begin{aligned}
Q_{50(u) r}= & 49.7(A)^{0.902}(S T+5)^{-0.939}(L A G+1)^{-0.441}(R U N F)^{1.068}(\text { table 1, hydrologic Region 2) } \\
& =49.7(131)^{0.902}(2.39+5)^{-0.939}(1.073+1)^{-0.441}(17.57)^{1.068} \\
& =9,560 \mathrm{ft}^{3} / \mathrm{s} .
\end{aligned}
$$

The 50-year weighted peak discharge at the gaged site (Normans at Albany) is:

$$
\left.Q_{50(\mathrm{G}) \mathrm{w}}=12,800 \mathrm{ft}^{3} / \mathrm{s} \text { (table } 8\right) \text {. }
$$

The estimate of the 50-year peak-discharge at the ungaged site near Westmere derived from the weighted estimate for the gaged site (at Albany) based on the drainage-area difference, is:

$$
Q_{50(U) g}=\left(A_{u} / A_{g}\right)^{b}\left(Q_{50(G) w}\right)
$$

$b$ is the exponent from the Region 2 drainage-area-only equations (table 3 )

$$
\begin{aligned}
Q_{50(U) g} & =(131 / 168)^{0.666}\left(12,800 \mathrm{ft}^{3} / \mathrm{s}\right) \\
& =10,800 \mathrm{ft}^{3} / \mathrm{s} .
\end{aligned}
$$

The weighted estimate of the $Q_{50}$ peak discharge at the ungaged site near Westmere is:

$$
\begin{aligned}
Q_{50(U) w} & =\frac{2 \Delta A}{A_{g}}\left(Q_{50(U) r}\right)+\left(1-\frac{2 \Delta A}{A_{g}}\right) Q_{50(U) g} \\
& =\frac{2(37)}{168}(9,560)+\left(1-\frac{2(37)}{168}\right)(10,800) \\
& =10,300 \mathrm{ft}^{3} / \mathrm{s} .
\end{aligned}
$$


Example 4. Ungaged site on a gaged stream, located between two streamflow-gaging stations. Estimate the 50-year peak discharge at the ungaged site Susquehanna River at Windsor. The example is for illustration purposes only because Susquehanna River at Windsor (01502731) is an active USGS streamflow-gaging station.

\section{Given:}

a) The drainage basin for this site is in hydrologic Region 4, between the gaged sites of Susquehanna River at Afton (01502701) and Susquehanna River at Conklin (01503000);

b) The drainage areas are: Afton $(01502701)=1,716 \mathrm{mi}^{2}\left(A_{g l}\right)$, Windsor $(01502731)=1,820 \mathrm{mi}^{2}\left(A_{u}\right)$, Conklin $(01503000)=2,232 \mathrm{mi}^{2}\left(A_{g 2}^{u}\right) ;$

c) Areas of lakes, ponds, and wetlands [storage $(S T)]=2.09$ percent of basin;

d) Mean annual runoff $(R U N F)=21.59$ in.;

e) Slope ratio $(S R)=S L / B S=(4.08 \mathrm{ft} / \mathrm{mi}) /(648 \mathrm{ft} / \mathrm{mi})=0.006$.

\section{Solution:}

The weighted 50-year peak-discharge estimate for the ungaged site (at Windsor), computed from the Afton gage data and the method shown in example 3:

$$
=51,800 \mathrm{ft}^{3} / \mathrm{s}\left(Q_{50(u) w}\right) .
$$

The weighted 50-year peak-discharge estimate for the ungaged site (at Windsor), computed from the Conklin gage data and the method shown in example 3, is:

$$
=50,400 \mathrm{ft}^{3} / \mathrm{s}\left(Q_{50(u 2) w}\right) .
$$

The final weighted 50-year peak-discharge estimate for the ungaged site (at Windsor) is computed as:

$$
\begin{aligned}
Q 50_{(U f) w} & =\left[Q_{50(U 1) w}\left(A_{g 2}-A_{u}\right)+Q_{50(U 2) w}\left(A_{u}-A_{g 1}\right)\right] / A_{g 2}-A_{g 1} \\
& =[(51,800)(2,232-1,820)+(50,400)(1,820-1,716)] /(2,232-1,716) \\
& =51,500 \mathrm{ft}^{3} / \mathrm{s} .
\end{aligned}
$$

The weighted 50-year peak-discharge estimate computed for each of the 388 gaging stations (table 8) were used to develop average, maximum, and minimum flood-frequency curves for each of the six hydrologic regions, and for New York (all sites including gages in adjacent States). The average flood-frequency curves for each hydrologic region, and for all sites combined, are shown in figure 20. The highest average peak-discharge runoff rates in cubic feet per second per square mile, for each recurrence interval are in hydrologic Region 3 (Catskill Mountains area), and the lowest are in Region 6 (Central Lowlands south of Lake Ontario).

The highest peak-discharge runoff rates (for recurrence intervals greater than 10 years) in the entire study area, in cubic feet per second per square mile, are those in hydrologic Region 2 (fig. 21), and the lowest (for all recurrence intervals) are in hydrologic Region 6. 


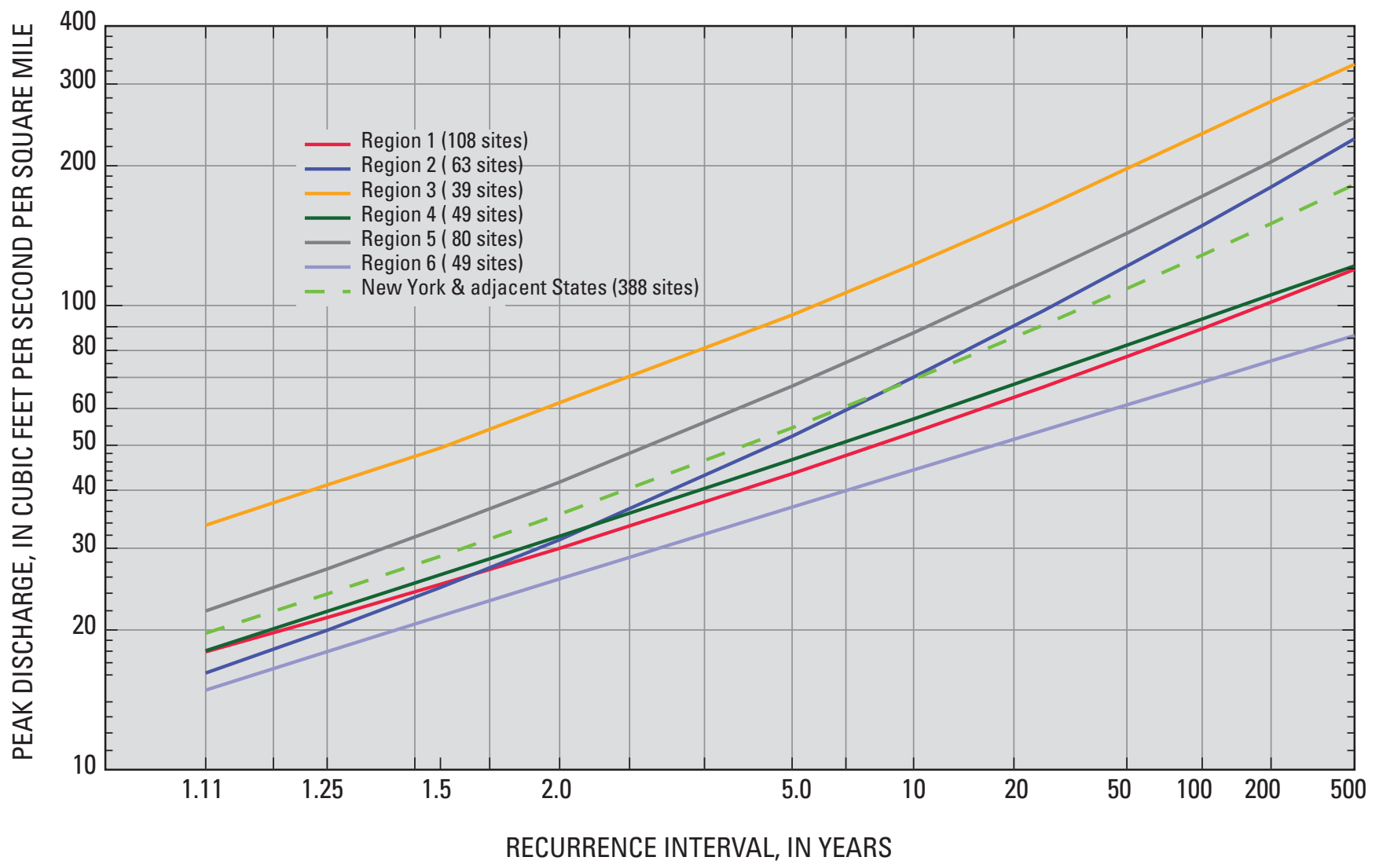

Figure 20. Average flood-frequency curves for six hydrologic regions of New York and for all 388 study sites combined (Region boundaries are shown in figure 2).

\section{Limitations, Accuracy, and Sensitivity of Regression Equations}

The regression equations developed in this study apply to streams in areas of New York where peak discharge is not greatly affected by stream regulation (flood-control reservoir) or by diversion or other manmade changes. The equations are not applicable to basins in urban areas (in which more than 15 percent of the basin is urbanized) unless the effects of urbanization on high flow are insignificant. Channelization, channel structures or constrictions, and large withdrawals from the stream may alter peak discharges and cause them to differ from those expected under undisturbed conditions. If the effects of urbanization can be quantified, adjustments to the rural peak-discharge estimates can be made through procedures outlined by Sauer and others (1983) to estimate peak discharge for urban areas. Lumia (1984) developed peak-discharge profiles for several streams in Rockland County, including many urbanized basins.

The relation between peak discharge and basin characteristics (actually the logarithms of these variables) given by the multiple linear regression equation is assumed to be linear only within the range of characteristics that define that relation. The suitability of the regional equations is undefined for streams having values beyond the ranges used, and extrapolation requires extreme caution or may be infeasible. The ranges of all basin characteristics used in the regression analyses for each region are given in table 4 .

Flood-frequency analyses assume the gaged record to be representative of long-term conditions; sampling error results from limitations on the number of years of gaged record available and from hydrologic conditions during the particular period sampled. The use of GLS regression equations minimizes, but does not prevent, this type of error.

The standard error of prediction is an index of the expected accuracy of the regression estimates. If all assumptions for applying regression are met, the discrepancy between the regression estimate and actual discharge will be within 1 standard error about 68 percent of the time.

Values for the basin characteristics used in the regression equations are computed or estimated from GIS procedures and datasets and, therefore, may be subject to some error in measurement and judgment. Sensitivity tests were conducted on the 50-year peak-discharge regression equation for each hydrologic region to estimate how much variability may be introduced by error in computing the basin-characteristic values. Results (table 5) should be indicative of the relative magnitude of the sensitivities of the equations for other frequencies. The data presented in table 5 were obtained through a process whereby the value of only one basin characteristic at a time was varied while all others were held constant. Each characteristic was increased 10, 20, and 30 percent, then decreased 10,20, and 30 percent; the percent 

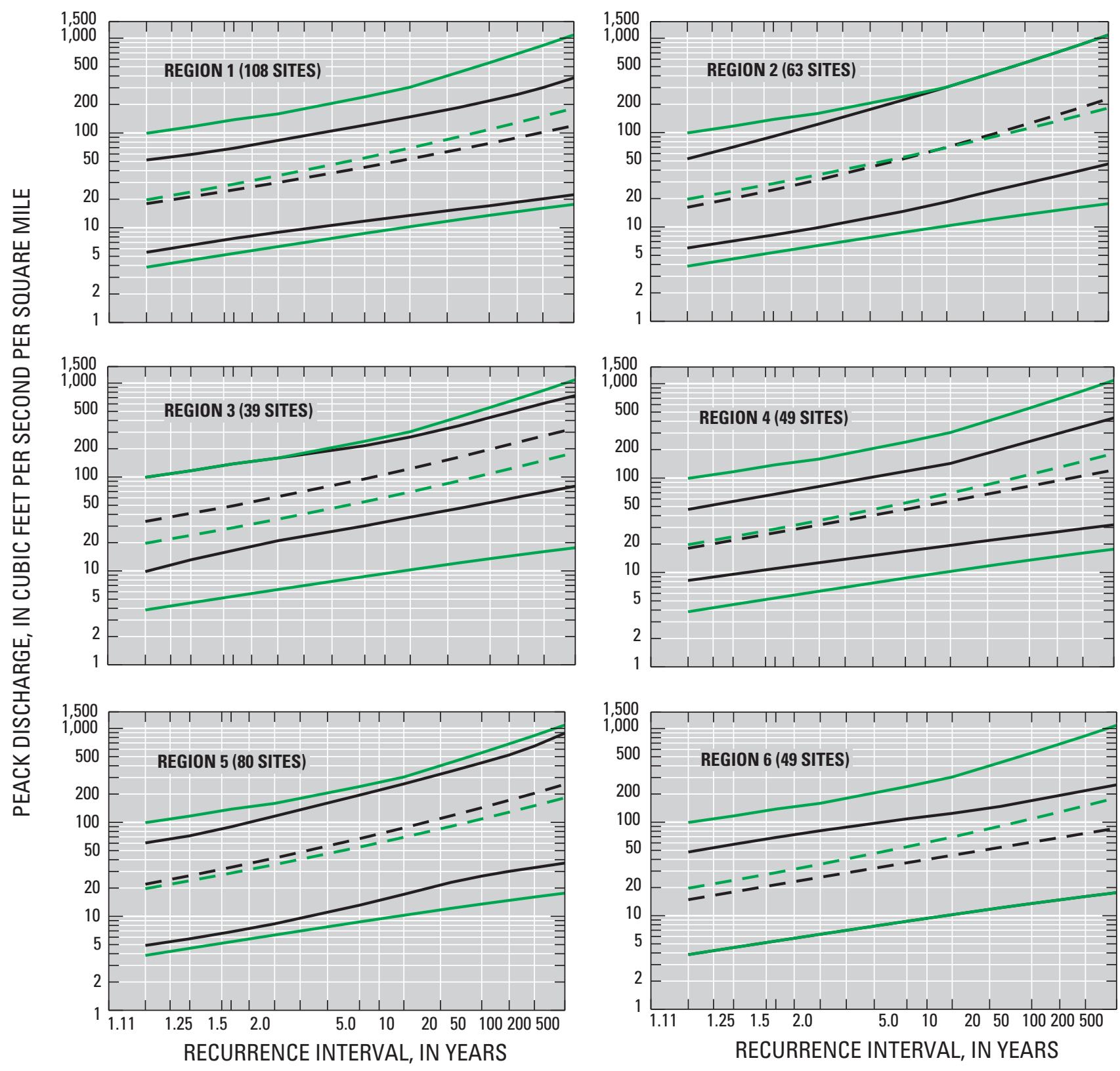

\section{EXPLANATION}

Region flood frequency

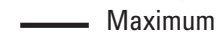

- - Average

Minimum

New York flood frequency

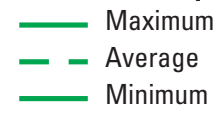

NEW YORK DATA REPRESENT 388 SITES WITHIN AND ADJACENT TO NEW YORK

Figure 21. Maximum, minimum, and average flood-frequency curves for six hydrologic regions of New York and for all 388 study sites combined (Region boundaries are shown in figure 2). 

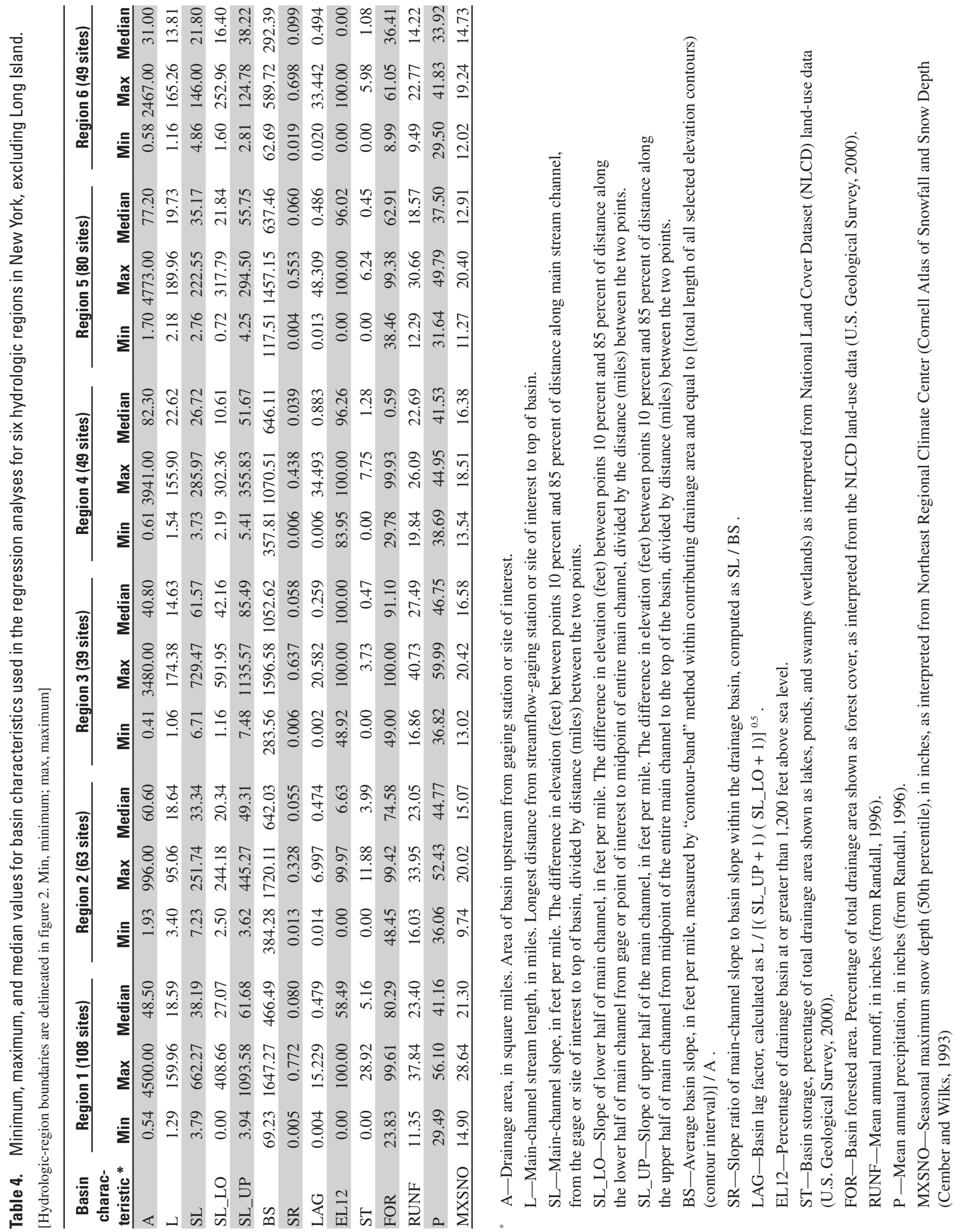


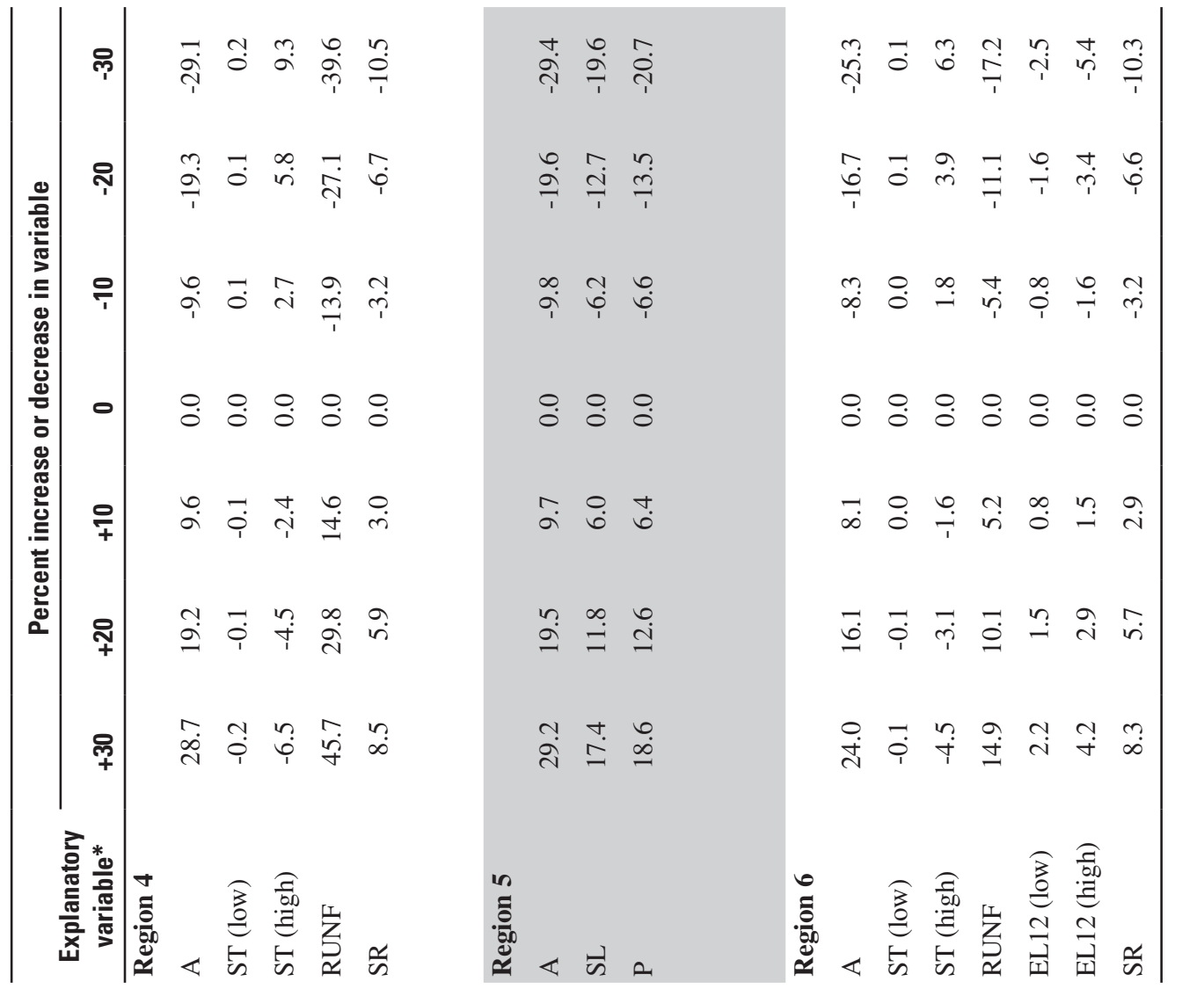

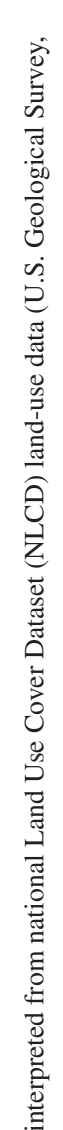

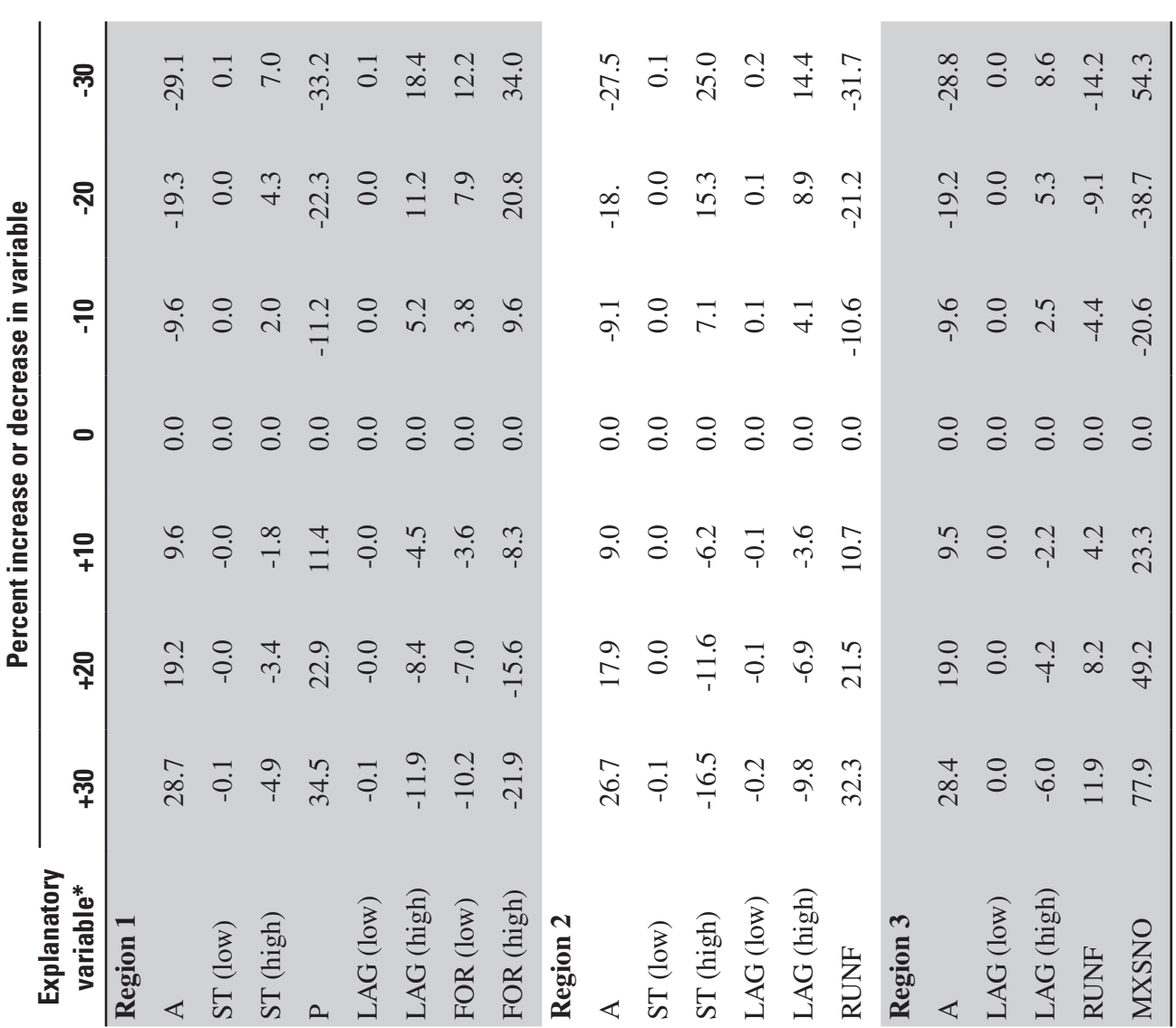

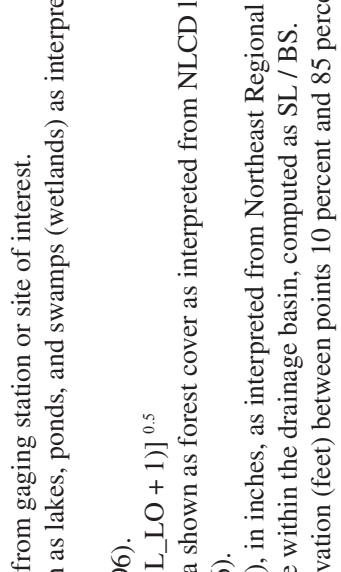

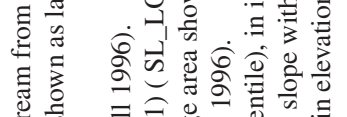

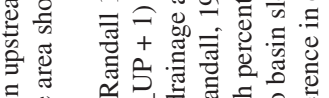


changes in the computed peak discharge are given in table 5. A test of variables for which no constant was added or subtracted (for example, drainage area), was done in which the regional mean value of each variable was used to compute a "base" 50-year peak discharge. The variable being tested was then changed by the above percentages, and the resulting percent changes in 50-year peak discharge were tabulated. A regional low and high value was used to compute a "base" 50-year peak discharge for variables to which constants were added or subtracted, such as forest cover (FOR) and storage (ST), because errors in computed discharges will be affected differently depending on the magnitude of the basin characteristic being tested. The variable to which peak discharges were most sensitive was maximum snow depth (applicable to Region 3); other factors to which peak discharge was sensitive were mean annual precipitation (Region 1), mean annual runoff (Regions 2 ,3, 4, and 6), and drainage area (all regions) (table 5).

Use of the flood-frequency equations presented herein requires use of the basin-characteristic datasets developed for these analyses. The use of different or updated characteristics may add uncertainty to the resulting floodfrequency estimates.

\section{Suggestions for Further Study}

Standard errors of the regional equations presented in this study are similar to those obtained from equations published by Lumia (1991) or may be smaller because (1) several small-streamflow-gaging stations have been added to the network, (2) methods of defining basin characteristics have been refined, (3) records of annual peak discharges have been extended by several years, and (4) analytical procedures have improved. Additional research on several factors related to flood-frequency relations, discussed in the next sections, could further decrease errors in future analyses.

\section{Skewness Coefficient}

Weighting the skewness coefficient computed from station records with a generalized skewness coefficient decreases possible bias caused by the relatively short periods of record of some stations. A weighting technique based on the number of years of record at each of 226 sites in New York was used to develop a statewide contour map of unbiased, generalized skew coefficients (Lumia and Baevsky, 2000). An error analysis showed the statewide map to have a lower mean-square-error (MSE) than the previously used nationwide map (Interagency Advisory Committee on Water Data, 1982). The statewide map was used to assign generalized skew values to each of the 388 sites used in this study and it can be updated and refined for future updates of the New York floodfrequency relations. Until then, the statewide map can be used to provide generalized skew values. Standard errors of the generalized skews for each of the six hydrologic regions are given in table 6 .

\section{Soil Maps}

Soil data were originally included in the regression analysis for this study. The soil values were computed from the 1:250,000-scale State Soil Geographic (STATSGO) data (National Resources Conservation Service, 1991; U.S. Geological Survey, 1997) and are based on generalized soils maps. The soil variables showed promise in improving the variability in some of the regional regression analyses but were not used in the final regression analyses because they were originally derived for use only in studies of multistate or national scale.

Future use of detailed soil maps, if available, might greatly increase the accuracy and predictive ability of the flood-frequency relations for the basins of the scale used in this study.

Table 6. Selected statistics for skew coefficients for each of six hydrologic regions of New York, excluding Long Island.

[Region boundaries are depicted in figure 2]

\begin{tabular}{|c|c|c|c|c|c|}
\hline \multirow[b]{2}{*}{$\begin{array}{l}\text { Hydrologic } \\
\text { region }\end{array}$} & \multirow[b]{2}{*}{$\begin{array}{c}\text { Number of stations } \\
\text { with at least } \\
20 \text { years of record }\end{array}$} & \multicolumn{4}{|c|}{ Station statistics (log base 10 units) } \\
\hline & & $\begin{array}{c}\text { Average } \\
\text { unbiased } \\
\text { station skew } \\
\end{array}$ & $\begin{array}{c}\text { Average } \\
\text { statewide } \\
\text { map skew } \\
\end{array}$ & $\begin{array}{c}\text { Mean square } \\
\text { error }\end{array}$ & $\begin{array}{c}\text { Standard } \\
\text { error }\end{array}$ \\
\hline 1 & 60 & 0.173 & 0.212 & 0.160 & 0.400 \\
\hline 2 and 3 & 65 & .361 & .410 & .205 & .453 \\
\hline 4 & 34 & -.092 & -.042 & .103 & .321 \\
\hline 5 & 48 & .172 & .288 & .213 & .462 \\
\hline 6 & 19 & -.199 & -.118 & .200 & .447 \\
\hline All regions & 226 & .156 & .219 & .179 & .423 \\
\hline
\end{tabular}




\section{Small-Stream Data}

Historical flood data from small streams with short periods of record could improve the current flood-frequency relations but are generally unavailable. Such information, if located within sources such as flood-insurance studies, government agencies, public libraries, or engineering records, might be best compiled in a format similar to that used by Lumia and Murray (1993).

Expansion of the current annual peak-discharge gaging-station network to include additional small streams, particularly sites with drainage areas less than $1.0 \mathrm{mi}^{2}$, could improve the accuracy of computed peak discharges for these sites. Supplementing the peak-discharge data base for small streams with data from a rainfall-runoff data network with subsequent modeling could also increase the accuracy and predictive ability of the flood-frequency relations.

\section{Other Factors}

Study of several other factors that affect peak discharges could potentially improve the flood-frequency relations for streams in New York. These factors include (1) the effect of mixed populations in annual peak-discharge data analysis (for example, floods caused by thunderstorms combined with floods from snowmelt or hurricanes); (2) the effects of incorporating additional basin characteristics in the regression analyses to account for unexplained variability in peak discharges; (3) the effect of regulation, with development of criteria for selecting or rejecting peak-discharge records on the basis of storage effects; (4) the effect of urbanization on flood frequencies; and (5) the effects of using detailed wetland maps.

\section{Summary}

This report presents the results of a cooperative study with the New York State Department of Transportation to derive regional regression equations from generalized leastsquares regression analysis for calculating the magnitude and frequency of floods on rural, unregulated streams in New York, excluding Long Island. Procedures for estimating peak discharges with 10 recurrence intervals $(1.25,1.5,2,5,10$, $25,50,100,200$, and 500 years) for each of 6 hydrologic regions of New York are given. The procedures depend on whether the site in question is gaged or ungaged, and whether the basin extends into an adjacent hydrologic region or State. The estimated standard error of prediction for the regression equations ranged from 14 to 43 percent. The data and final estimates of peak discharges for 10 recurrence intervals at the 388 gaging stations used for the analyses are summarized in tables and graphs. Four examples of peak-discharge computations are provided. The limitations and accuracy of the estimating equations and the relative importance of the significant variables (sensitivity analysis) are given in several tables. Maximum snow depth, mean annual precipitation, mean annual runoff, and drainage area are shown to be the most sensitive variables.

Suggestions for additional study include development of a detailed soils map for New York. Alternative peak-discharge estimating equations, based on drainage area only, are included. These equation provide estimates of peak discharges that are easier to compute, but less accurate, than those calculated through the full-regression equations.

A DVD (in the pocket at the back of the report) contains procedures and GIS datasets for computation of basin characteristics needed for the flood-frequency regression equations. Procedures are also included for the computation of peak-discharges for 10 recurrence intervals at any stream location in New York where the regression equations are applicable. A spreadsheet is also included on the DVD for computation of peak discharges at ungaged sites, gaged sites, and ungaged sites on gaged streams for each of the six hydrologic regions.

\section{Acknowledgments}

The New York State Department of Transportation, the New York State Department of Environmental Conservation, the U.S. Army Corps of Engineers, the Hudson River -Black River Regulating District, the New York Power Authority, Reliant Energy, the New York City Department of Environmental Protection, and several other municipal and county governments provided support for data-collection programs. The authors also acknowledge the USGS personnel who collected and analyzed data for this report, and Elizabeth Ahearn and Scott Olson of the USGS for valuable technical reviews.

\section{Selected References}

Ahearn, E.A., 2004, Regression equations for estimating flood flows for the 2-, 10-, 25-, 50-, 100-, and 500-year recurrence intervals in Connecticut: U.S. Geological Survey Scientific Investigations Report 2004-5160, 62 p.

Benson, M.A., 1962, Factors influencing the occurrence of floods in a humid region of diverse terrain: U.S. Geological Survey Water-Supply Paper 1580-B, 64 p.

Cember, R.P., and Wilks, D.S., 1993, Climatological atlas of snowfall and snow depth for the northeastern United States and southeastern Canada: Publication no. RR 93-1, Northeast Regional Climate Center, Cornell University, Ithaca, NY, $18 \mathrm{p}$.

Darmer, K.I., 1970, A proposed streamflow data program for New York: U.S. Geological Survey Open-File Report, 29 p. 
Environmental Systems Research Institute, Inc. (ESRI), 1994, ARC/INFO users guide, version 7.0: Redlands, CA.

Fenneman, N.M., 1938, Physiography of eastern United States: New York, McGraw-Hill, 714 p.

Fisher, R.A., 1931, The moments of the distribution of normal samples of measures of departure from normality: Proceedings of the Royal Society of London, v. 130, p. 16-28.

Hardison, C.H., 1971, Prediction error of regression estimates of streamflow characteristics at ungaged streams, in Geological Survey Research 1971: U.S. Geological Survey Professional Paper 750-C, p. C228-C236.

Harvey, C.A., and Eash, D.A., 1995, Description, instructions, and verification for Basinsoft, a computer program to quantify drainage-basin characteristics: U.S. Geological Survey Water-Resources Investigations Report 95-4287, 25 p.

Helsel, D.R., and Hirsch, R.M., 1992, Statistical methods in water resources: New York, Elsevier, 522 p.

Hodgkins, G., 1999, Estimating the magnitude of peak flows for streams in Maine for selected recurrence intervals: U.S. Geological Survey Water-Resources Investigations Report 99-4008, 45 p.

Interagency Advisory Committee on Water Data, 1982, Guidelines for determining flood flow frequency-Bulletin 17B of the Hydrology Subcommittee: U.S. Geological Survey, Office of Water-Data Coordination, 183 p.

Jennings, M.E., Thomas, W.O., and Riggs, H.C., comps., 1994, Nationwide summary of U.S. Geological Survey regional regression equations for estimating magnitude and frequency of floods for ungaged sites, 1993: U.S. Geological Survey Water Resources Investigations Report 94-4002, $196 \mathrm{p}$.

Kirby, William, 1981, Annual flood-frequency analysis using U.S. Water Resources Council guidelines (Program J407): U.S. Geological Survey National Water Storage and Retrieval System, v. 4, chap. I, section C, 57 p.

Lumia, Richard, 1984, Flood-discharge profiles of selected streams in Rockland County, New York: U.S. Geological Survey Water Resources Investigations Report 84-4049, 32 p.

Lumia, Richard, 1991, Regionalization of flood discharges for rural, unregulated streams in New York, excluding Long Island: U.S. Geological Survey Water Resources Investigations Report 90-4197, 119 p.

Lumia, Richard, and Baevsky, Y.H., 2000, Development of a contour map showing generalized skew coefficients of annual peak discharges of rural, unregulated streams in New York, excluding Long Island: U.S. Geological Survey Water Resources Investigations Report 00-4022, 11 p.
Lumia, Richard, and Murray, P.M., 1993, Maximum known stages and discharges of New York streams, 1865-1989, with descriptions of five selected floods, 1913-85: U.S. Geological Survey Water Resources Investigations Report 92-4042, 123 p.

Lyford, F.P., Dysart, J.E., Randall, A.D., and Kontis, A.L., 1984, Glacial aquifer systems in the northeastern United States - a study plan: U.S. Geological Survey Open-File Report 83-928, 33 p.

National Oceanic and Atmospheric Administration, 1980, Climates of the States, volume 1, Alabama-North Dakota: p. 530-539.

Natural Resources Conservation Service, National Soil Survey Center, 1991, STATe Soil GeOgraphic (STATSGO) database: Miscellaneous Publication 1492, 110 p. (revised July 1994).

Olson, S.A., 2002, Flow-frequency characteristics of Vermont streams: U.S. Geological Survey Water Resources Investigations Report 2002-4238, 47 p.

Randall, A.D., 1996, Mean annual runoff, precipitation, and evapotranspiration in the glaciated northeastern United States, 1951-80: U.S. Geological Survey Open-File Report 96-395, 2 pls.

Rasmussen, T.J., and Perry, C.A., 2001, Trends in peak flows of selected streams in Kansas: U.S. Geological Survey Water-Resources Investigations Report 01-4203, 62 p.

Ries, K.G., III, Crouse, M.Y., comps., 2002, The National Flood Frequency Program, Version 3: A computer program for estimating magnitude and frequency of floods for ungaged sites, 2002: U.S. Geological Survey Water Resources Investigations Report 02-4168, 42 p.

Robison, L.F., 1961, Floods in New York-magnitude and frequency: U.S. Geological Survey Circular 454, 10 p.

SAS [Statistical Analysis System] Institute, Inc., 1982, SAS user's guide—statistics, 1982 ed.: Cary, NC, 584 p.

Sauer, V.B., Thomas, W.O., Jr., Stricker, V.A., and Wilson, K.V., 1983, Flood characteristics of urban watersheds in the United States: U.S. Geological Survey Water-Supply Paper 2207, 63 p.

Speer, P.R., and Gamble, C.R., 1965, Magnitude and frequency of floods in the United States, Part 3-A, Ohio River basin except Cumberland and Tennessee River basins: U.S. Geological Survey Water-Supply Paper 1675, 630 p.

Stankowski, S.J., 1974, Magnitude and frequency of floods in New Jersey, with effects of urbanization: New Jersey Department of Environmental Protection-Division of Water Resources, Special Report 38, 46 p. 
Stedfast, D.A., 1986, Evaluation of six methods for estimating magnitude and frequency of peak discharges of urban streams in New York: U.S. Geological Survey Water Resources Investigations Report 84-4350, 24 p.

Stedinger, J.R., and Tasker, G.D., 1985, Regional hydrologic analysis 1, ordinary, weighted, and generalized least squares compared: Water Resources Research, v. 21, no. 9, p. 1421-1432.

Stuckey, M.H., and Reed, L.A., 2000, Techniques for estimating magnitude and frequency of peak flows for Pennsylvania streams: U.S. Geological Survey Water Resources Investigations Report 2000-4189, 43 p.

Tasker, G.D., 1982, Simplified testing of hydrologic regression regions: American Society of Civil Engineers, Journal of Hydraulics Division, v. 108, no HY10, p. 1218-1222.

Tasker, G.D., and Stedinger, J.R., 1989, An operational GLS model for hydrologic regression: Journal of Hydrology, v. 111, p. 361-375.

Tice, R.H., 1968, Magnitude and frequency of floods in the United States, part 1-B, North Atlantic Slope basins, New York to York River: U.S. Geological Survey Water-Supply Paper 1672, $585 \mathrm{p}$.

U.S. Geological Survey, 1997, STATSGO, Soil characteristics for the conterminous United States: U.S. Geological Survey Open-File Report 656, accessed at URL http://water.usgs. gov/GIS/metadata/usgswrd/muid.html.

U.S. Geological Survey, 2000, National Land Cover Dataset: U.S. Geological Survey Fact Sheet 108-00, accessed at http://mac.usgs.gov/mac/isb/pubs/factsheets/.
U.S. Geological Survey, 2001, National Elevation Dataset: U.S. Geological Survey, accessed at http://gisdata.usgs. gov/NED/.

U.S. Water Resources Council, 1981, Guidelines for determining floodflow frequency: Hydrology Subcommittee Bulletin 17B, 28 p., appendix.

Wagner, L.A., 1982, Drainage areas of New York streams, by river basins - a stream gazetteer, Part 1, data compiled as of October 1980: U.S. Geological Survey Open-File Report 81-1055, 359 p.

Wandle, W.S., Jr., 1977, Estimating the magnitude and frequency of floods on natural-flow streams in Massachusetts: U.S. Geological Survey Water Resources Investigations Report 77-39, 26 p.

Wandle, W.S., Jr., 1983, Estimating peak discharges of small, rural streams in Massachusetts: U.S. Geological Survey Water-Supply Paper 2214, 26 p.

Wiitala, S.W., 1965, Magnitude and frequency of floods in the United States, Part 4, St. Lawrence River basin: U.S. Geological Survey Water-Supply Paper 1677, 357 p.

Zembrzuski, T.J., Jr., and Dunn, Bernard, 1979, Techniques for estimating magnitude and frequency of floods on rural, unregulated streams in New York State excluding Long Island: U.S. Geological Survey Water Resources Investigations Report 79-83, 66 p. 
Tables 7-10 


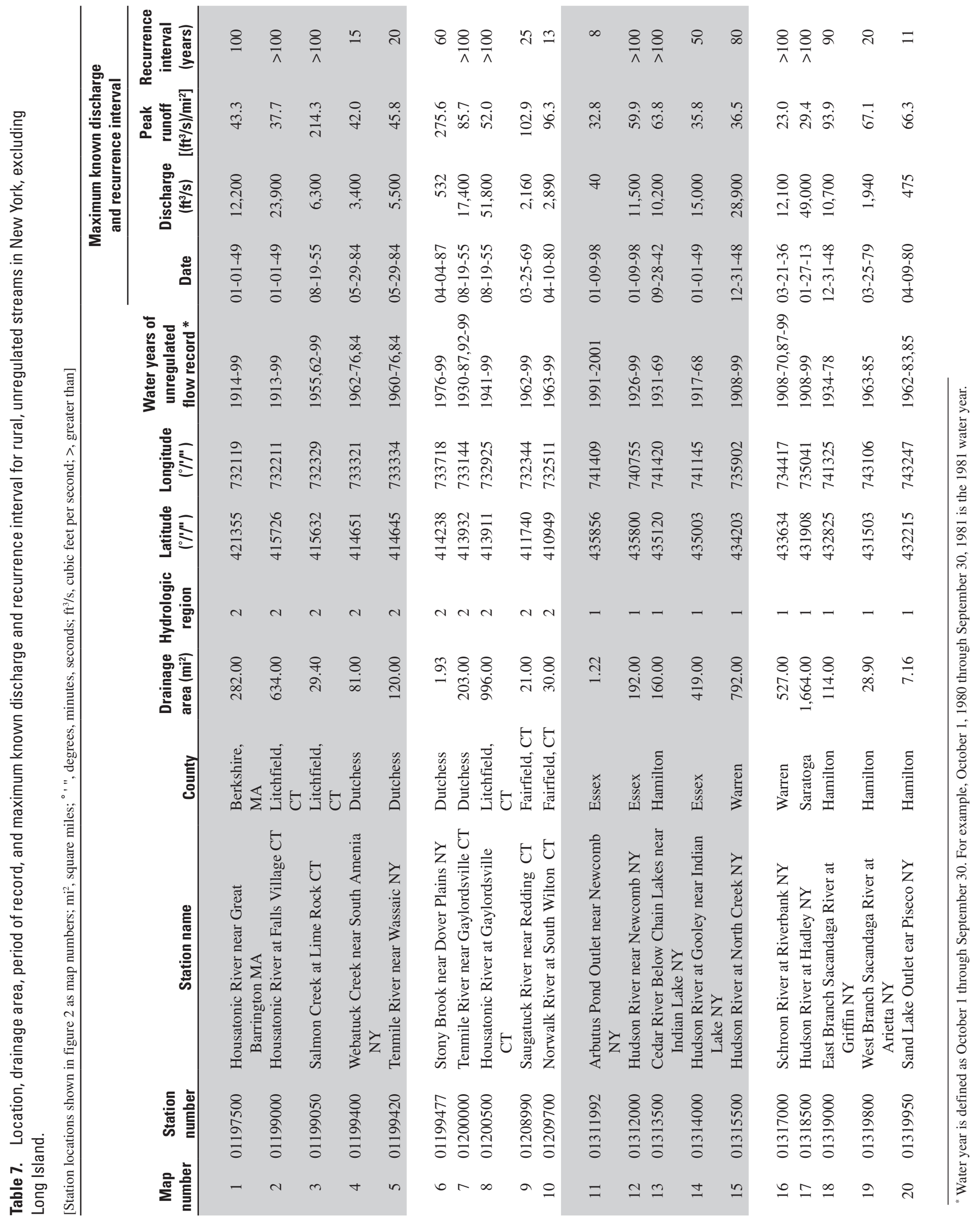




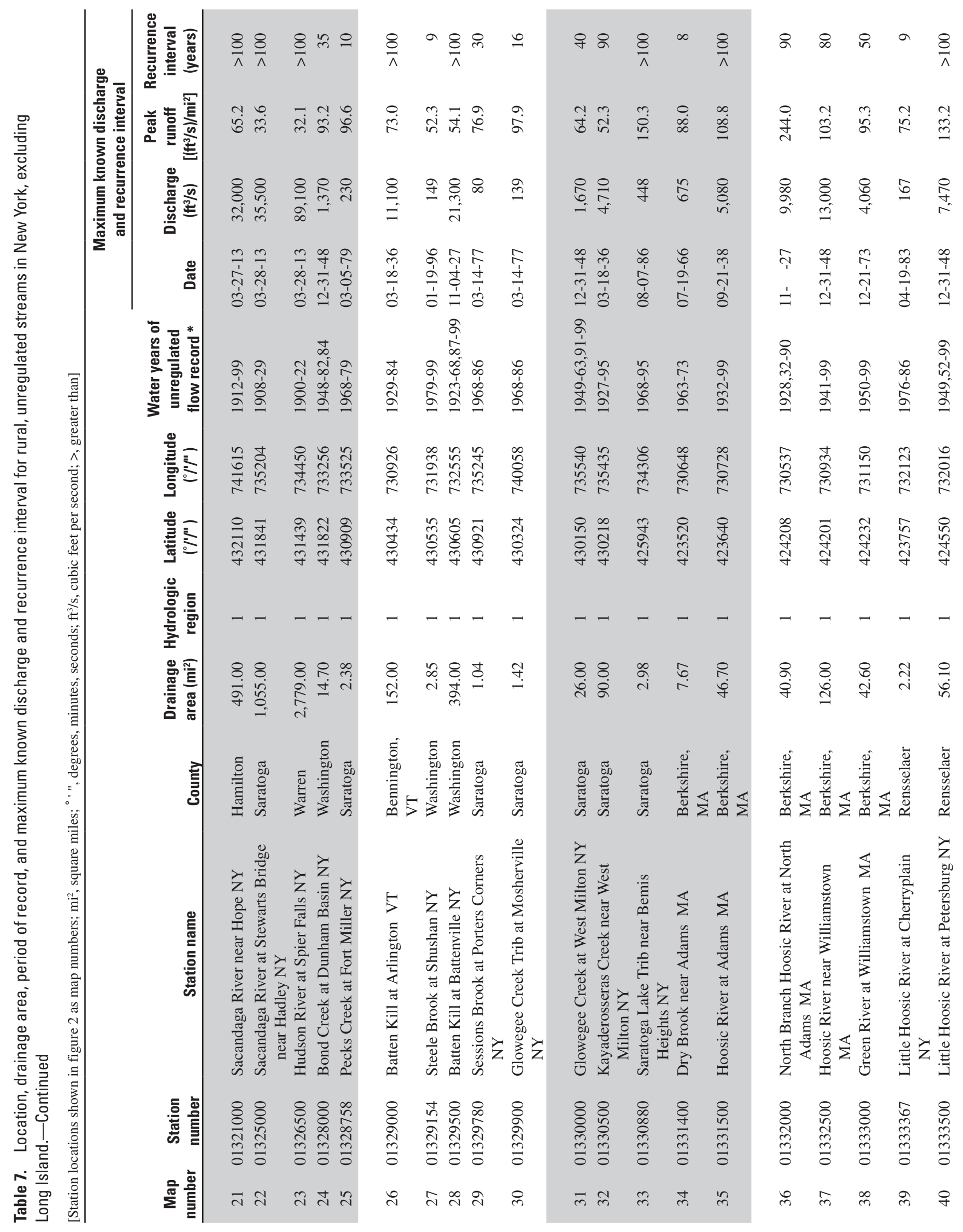




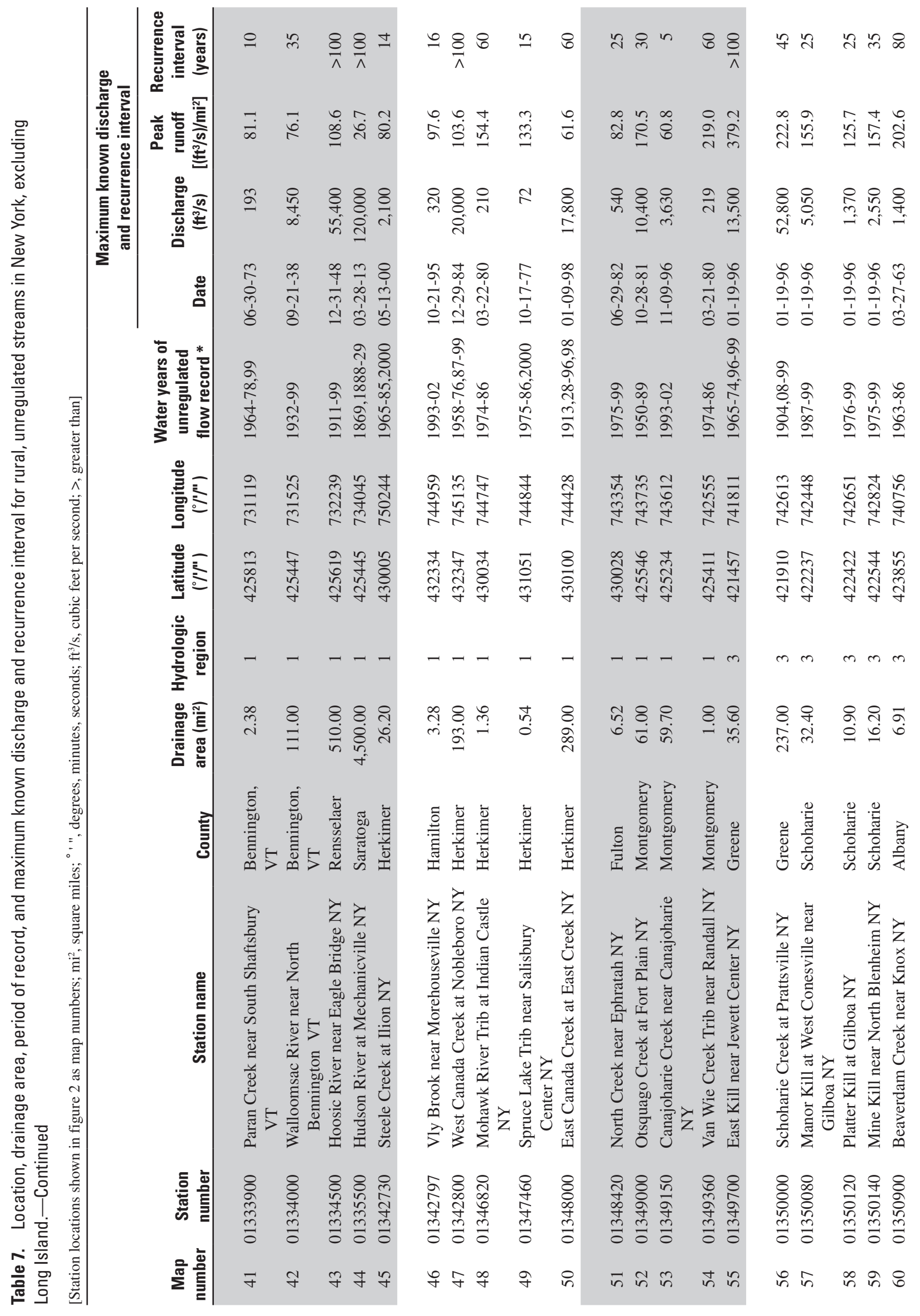




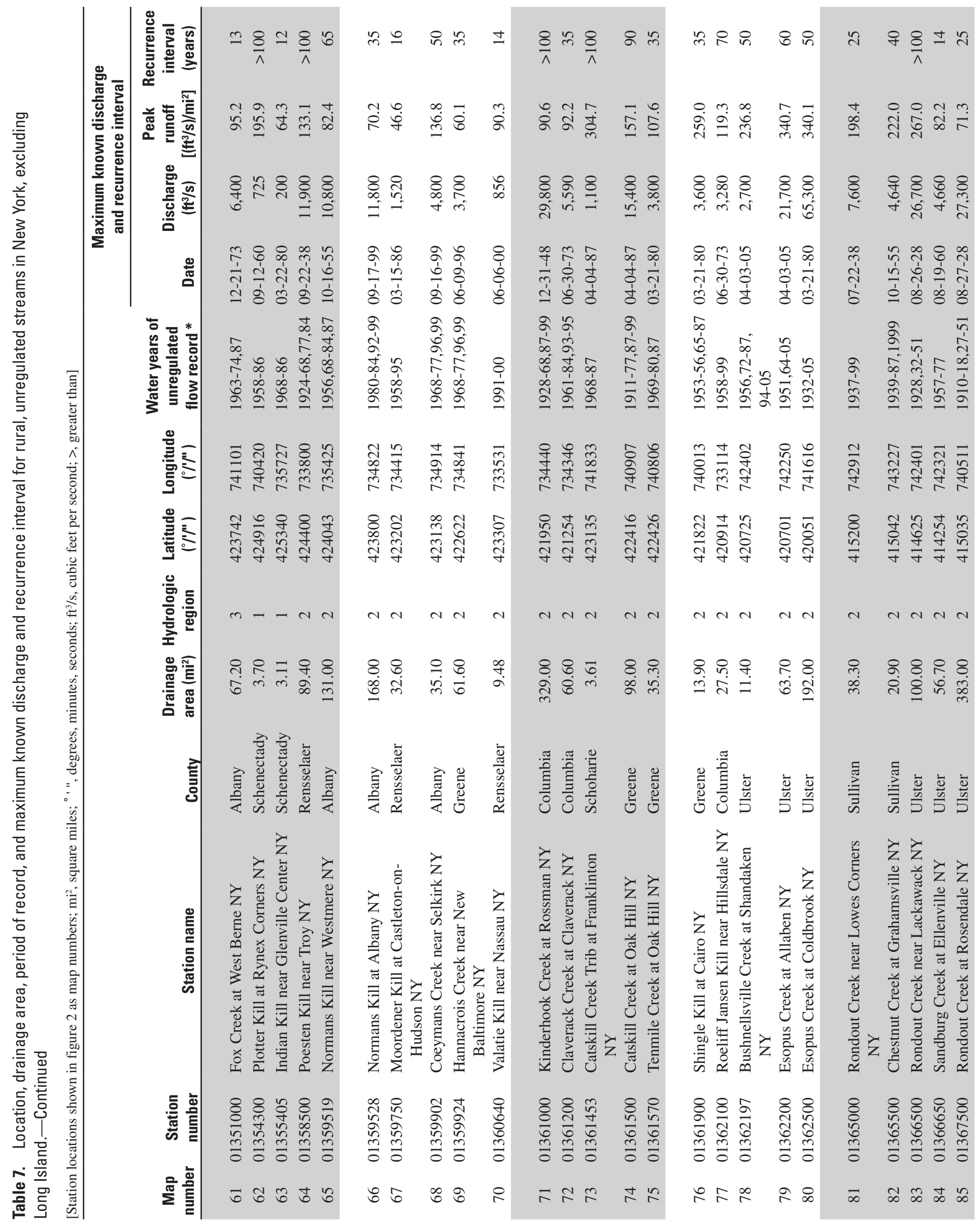




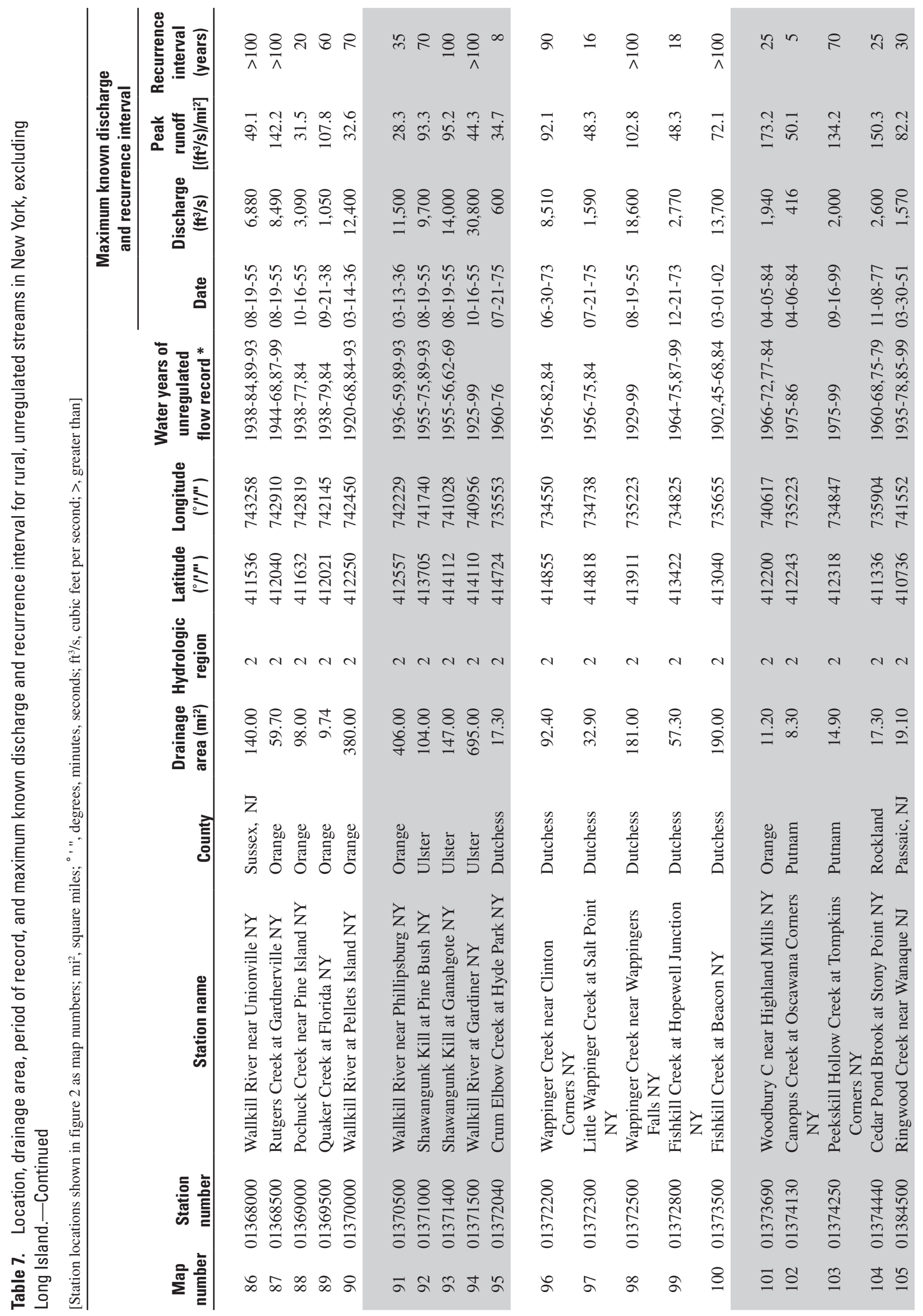




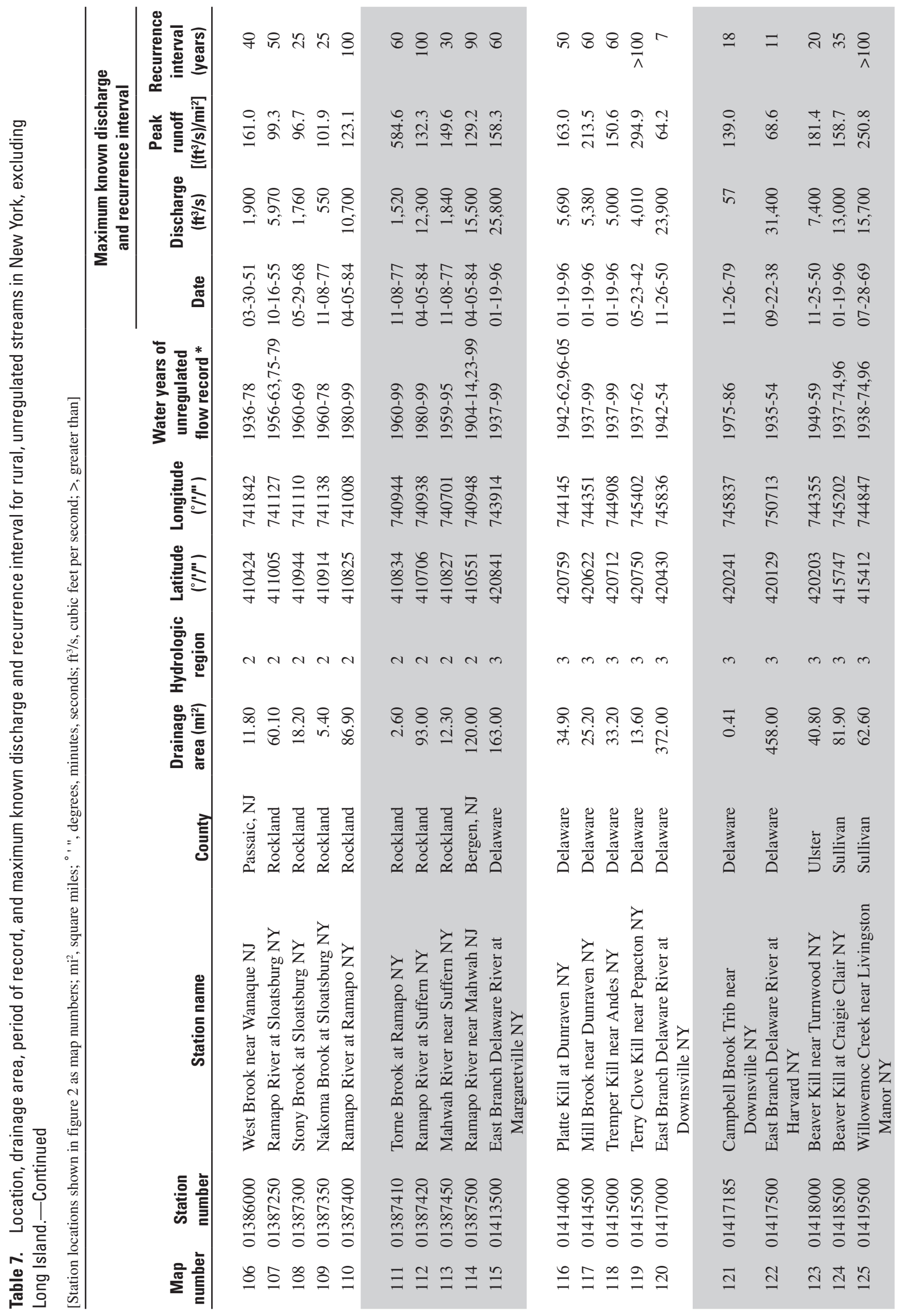




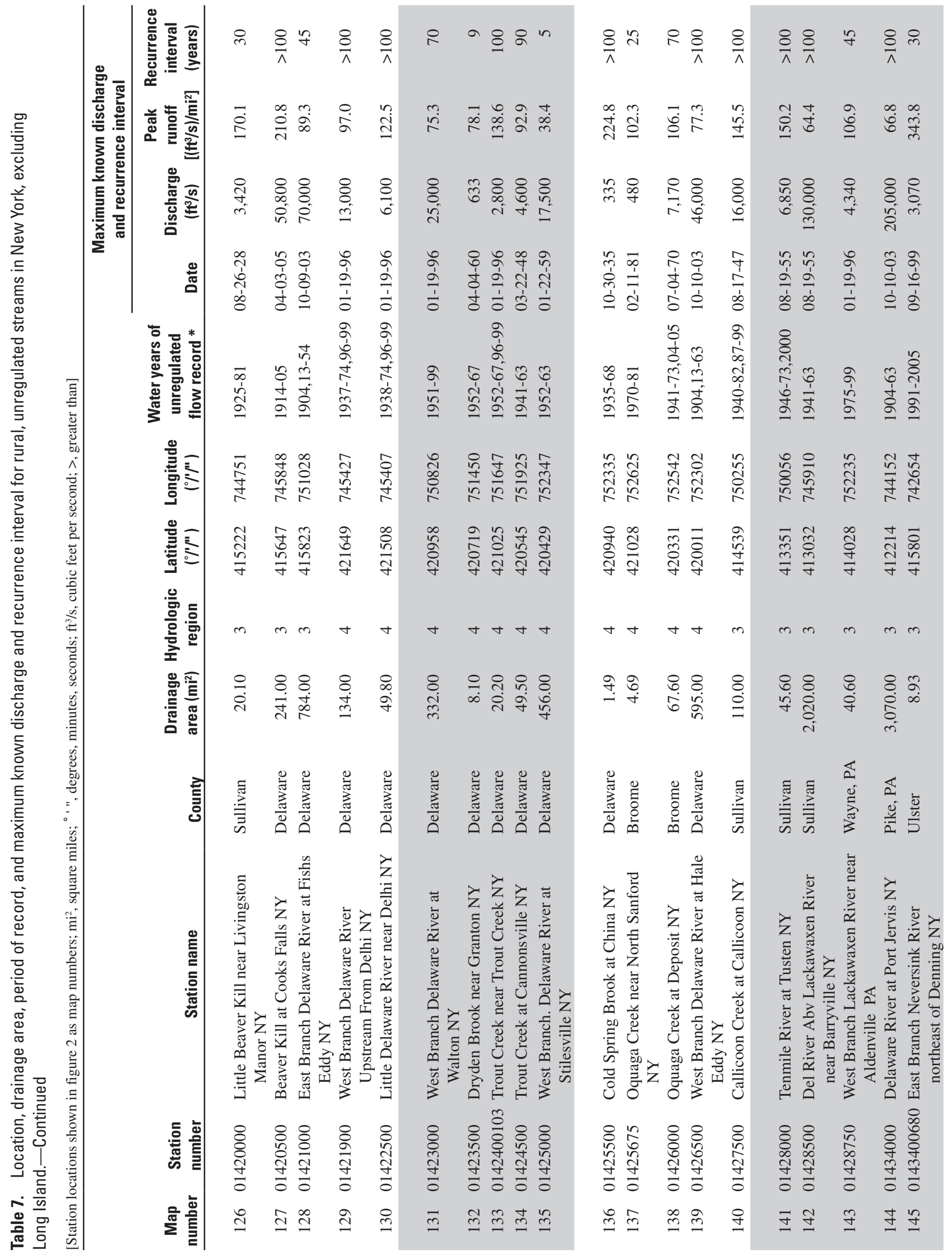




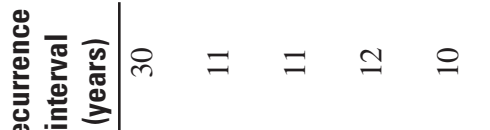

$$
\circ
$$
$\stackrel{2}{\bar{T}}$

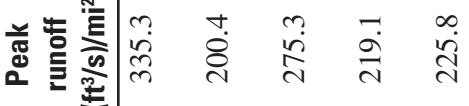

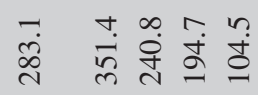

$=\frac{8}{\wedge} \frac{8}{\wedge} \frac{8}{\wedge}^{\infty}$

$\therefore$ in $\because \cong \frac{8}{\wedge}$

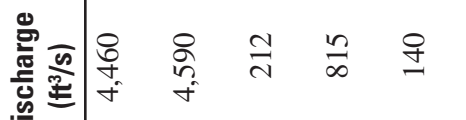

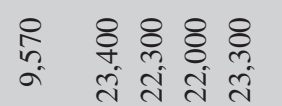

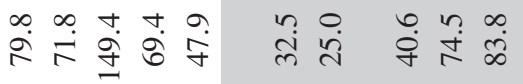

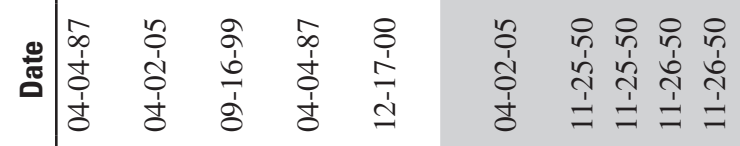

훙 훙

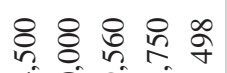

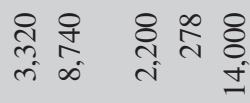

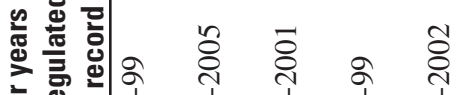

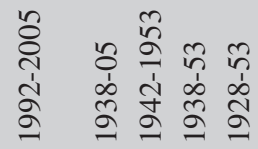

ก $n n n$

ஸे

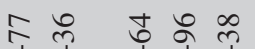

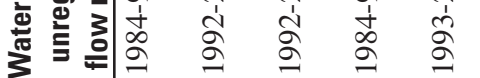

은

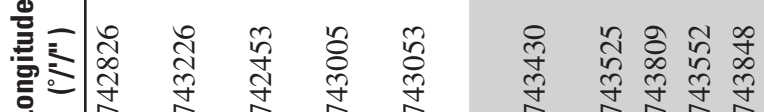

- का के के वे

.

迹

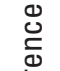

言

흠

离

$\frac{\pi}{2}$

言

言

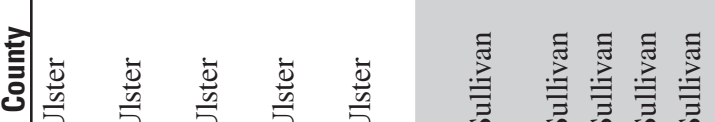

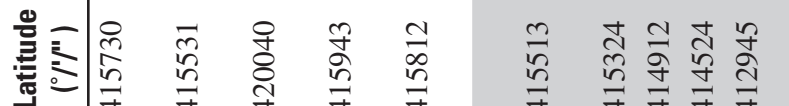
के

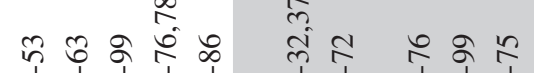

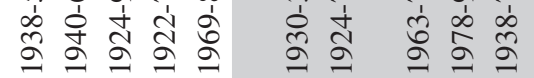

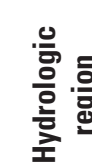

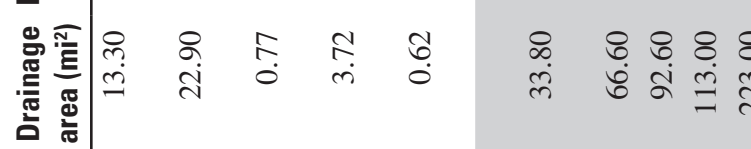

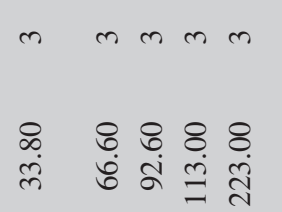

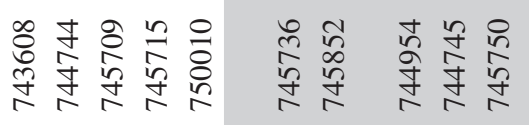

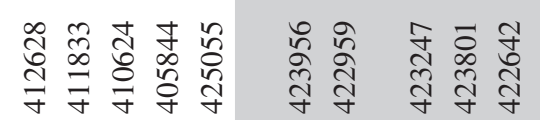

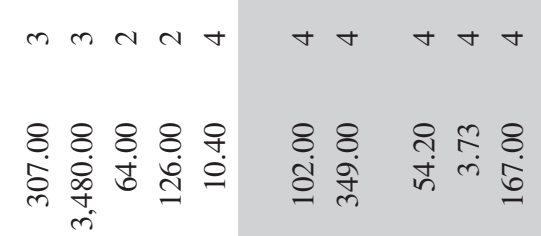

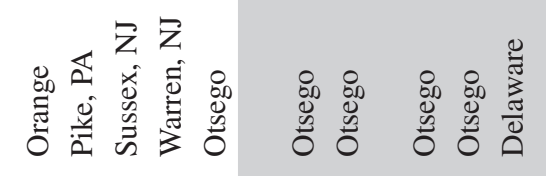

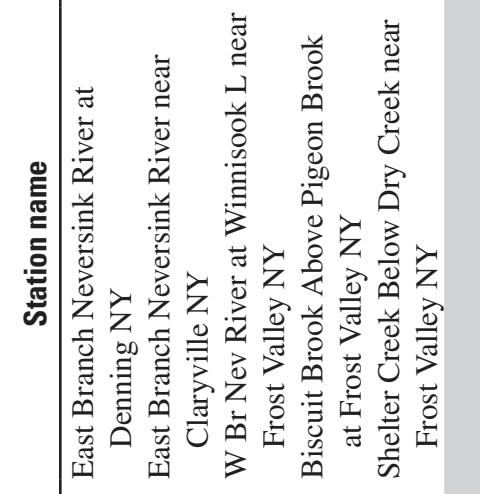

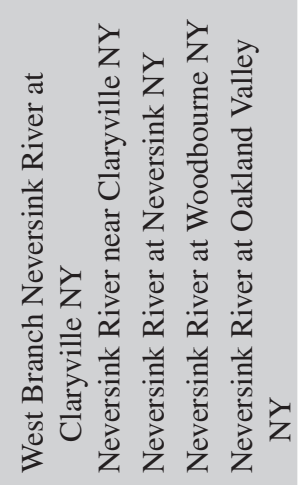

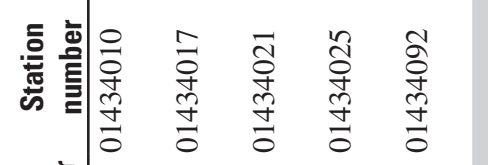

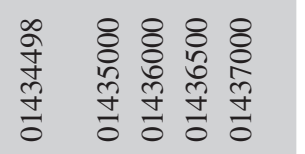

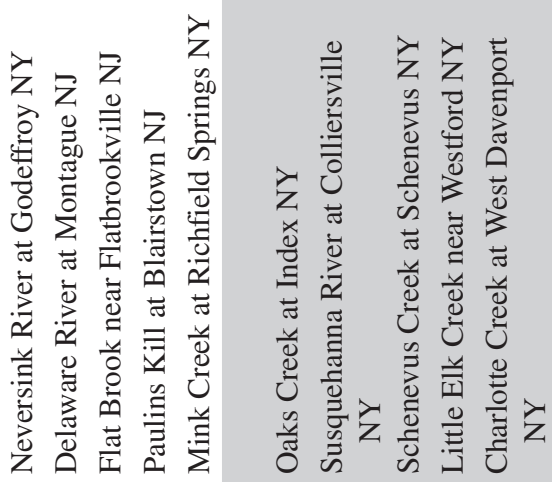

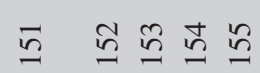

웅 웅웅

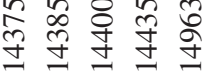

\& \& \&

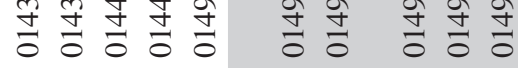






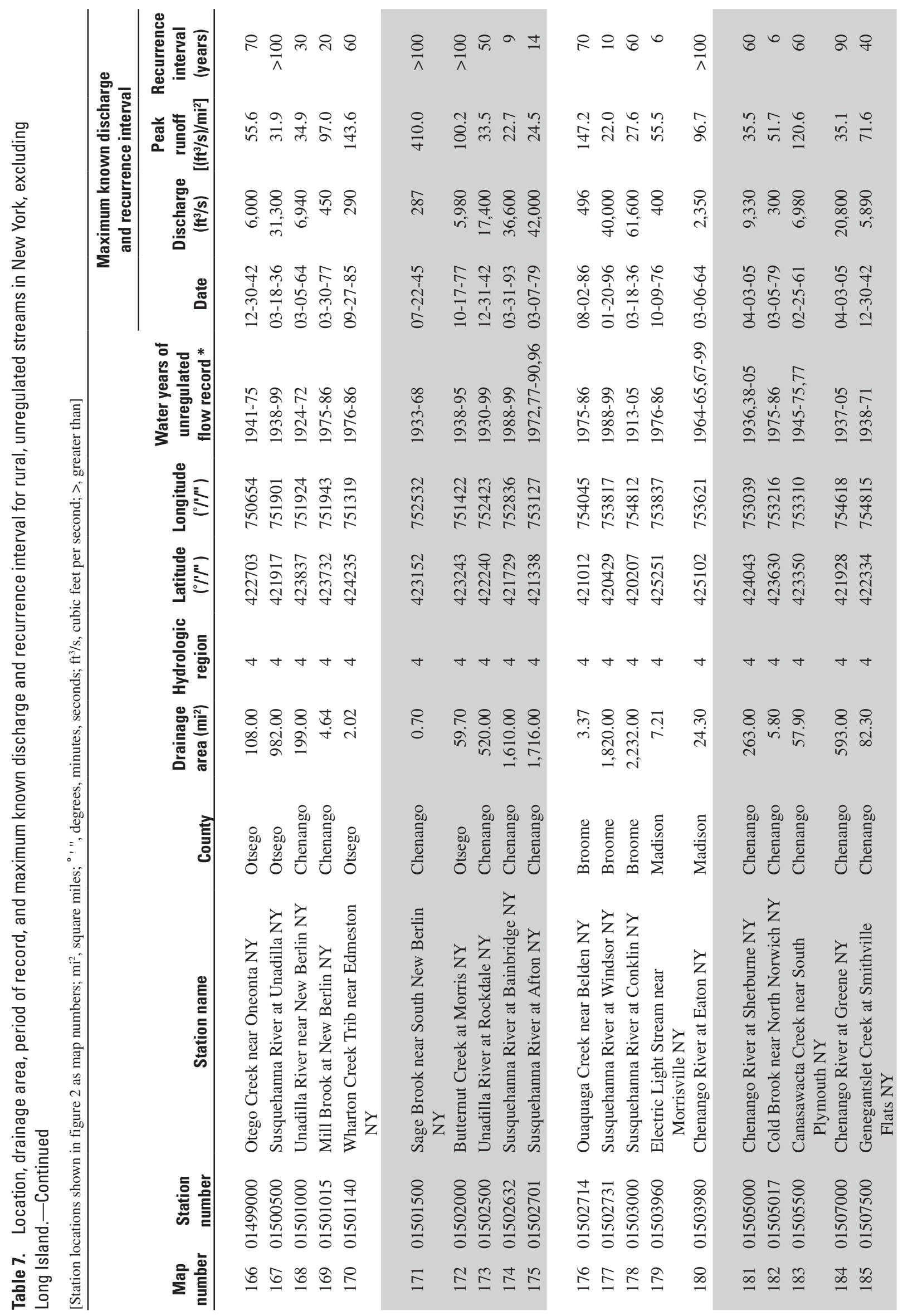




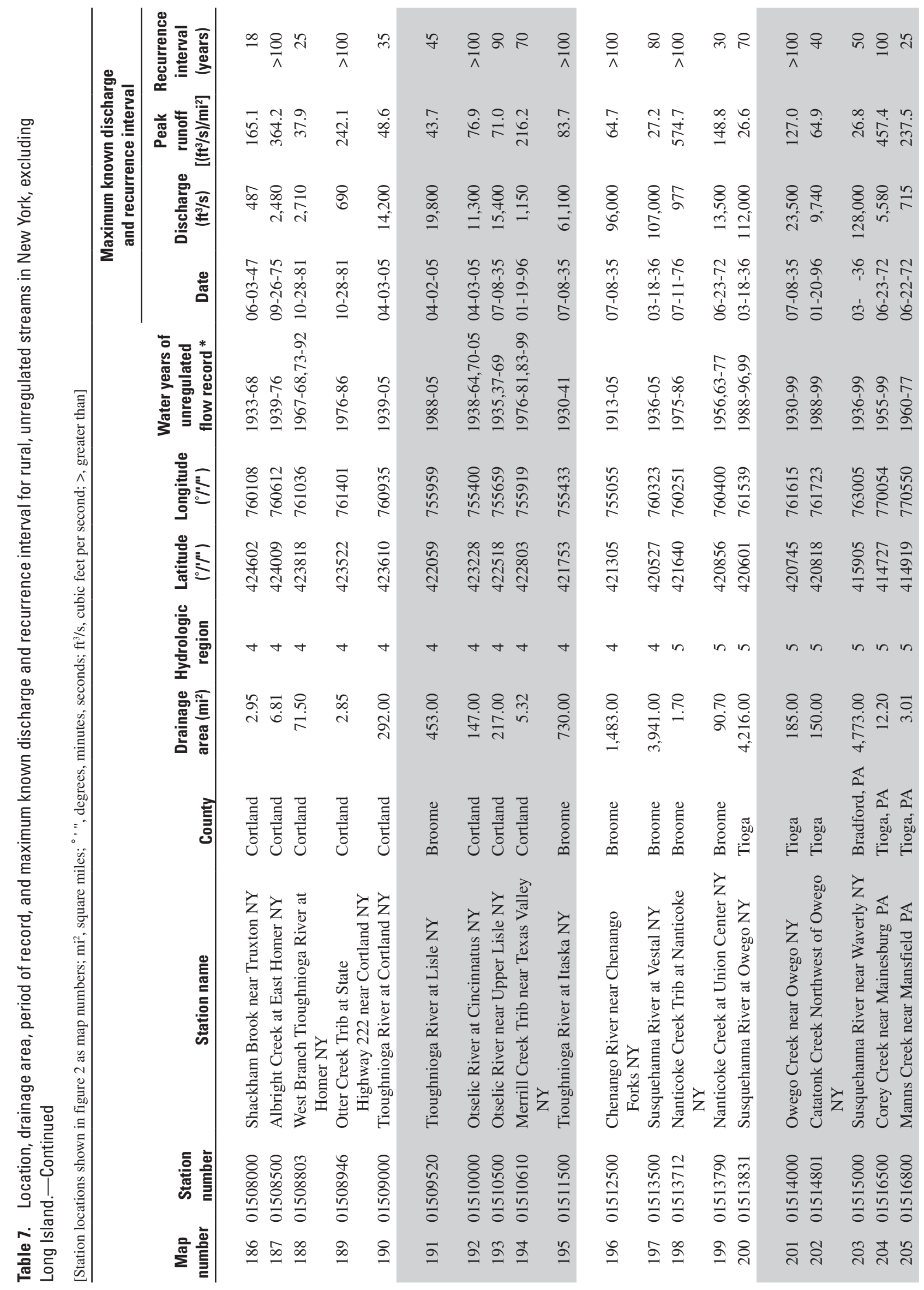




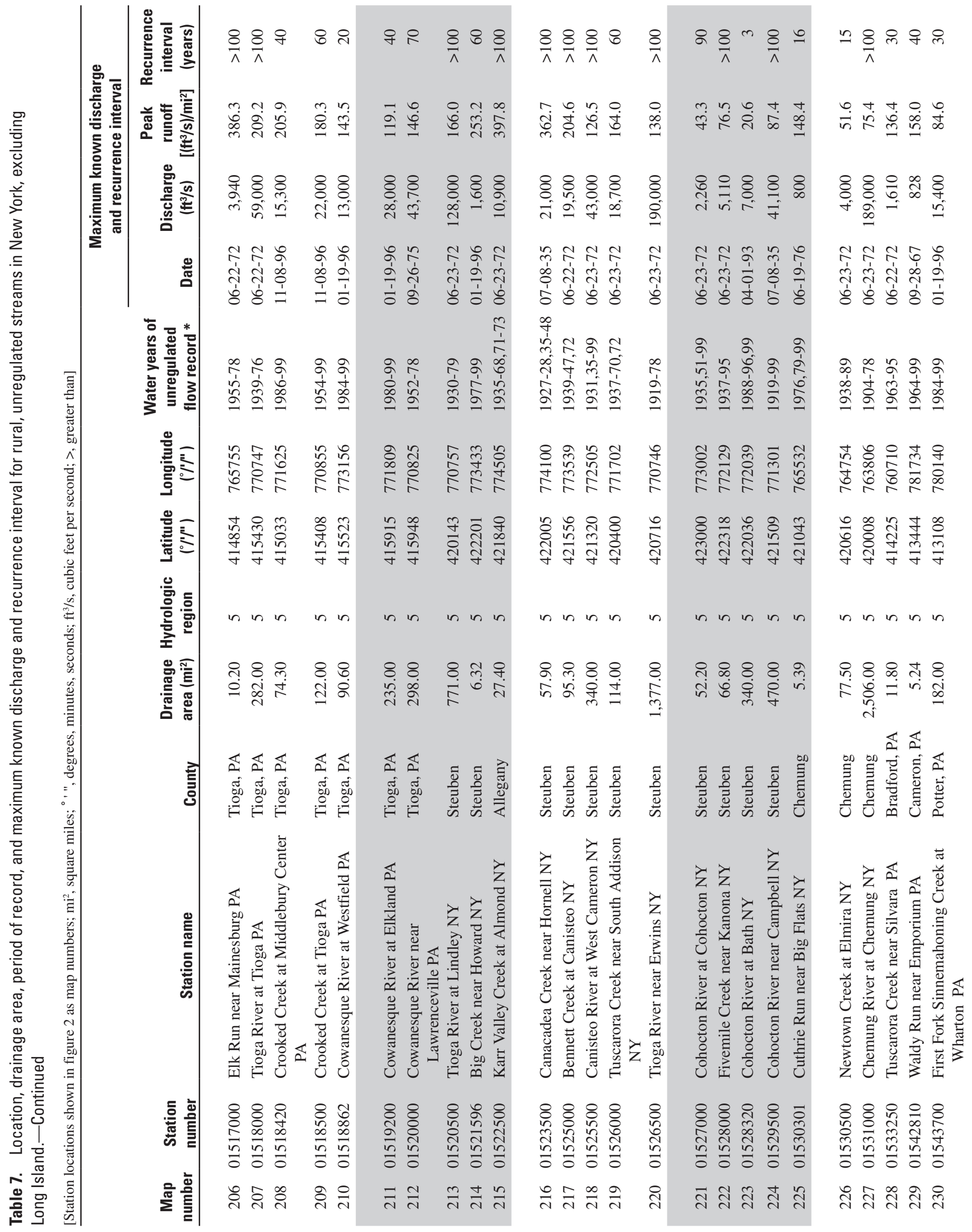




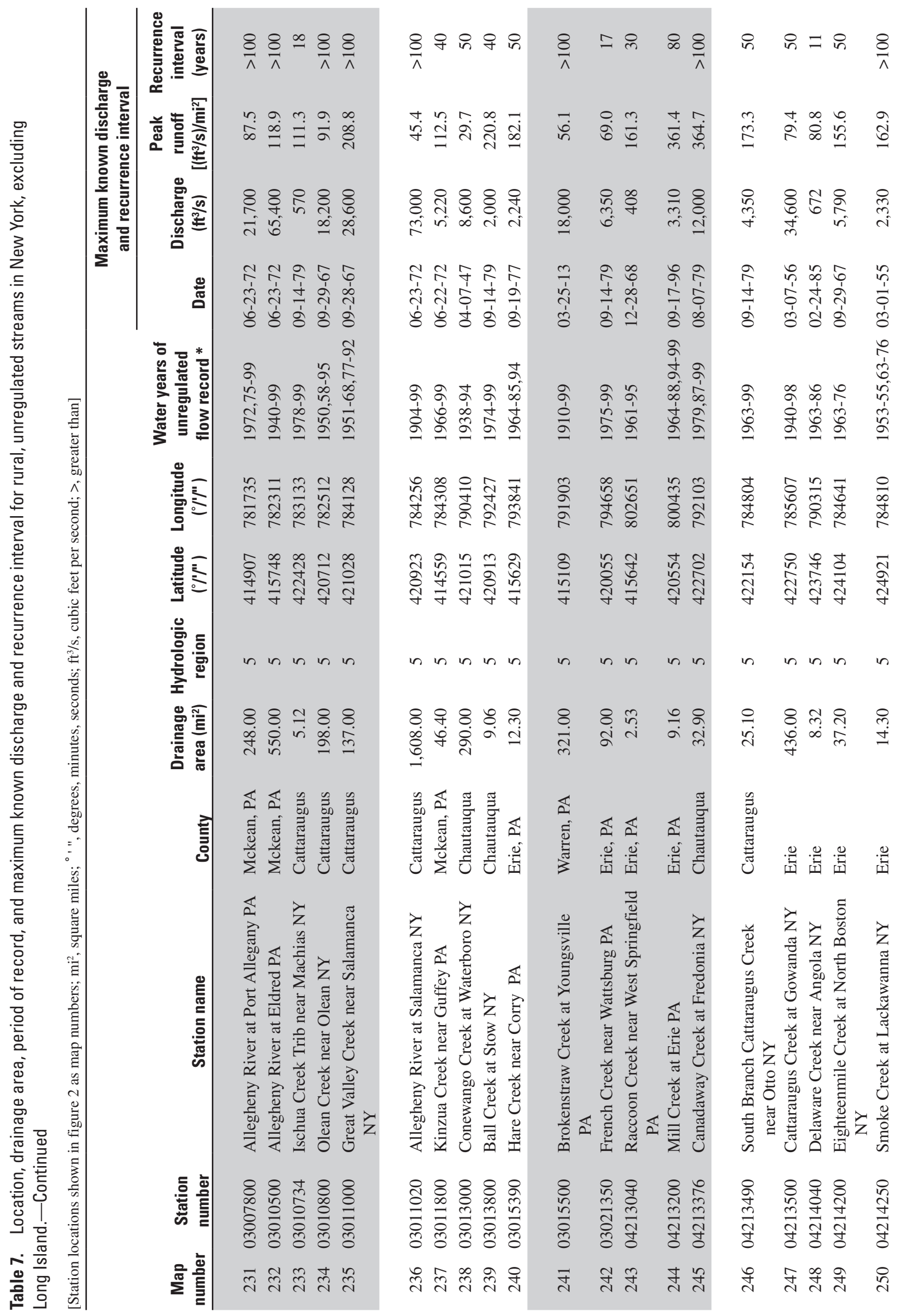




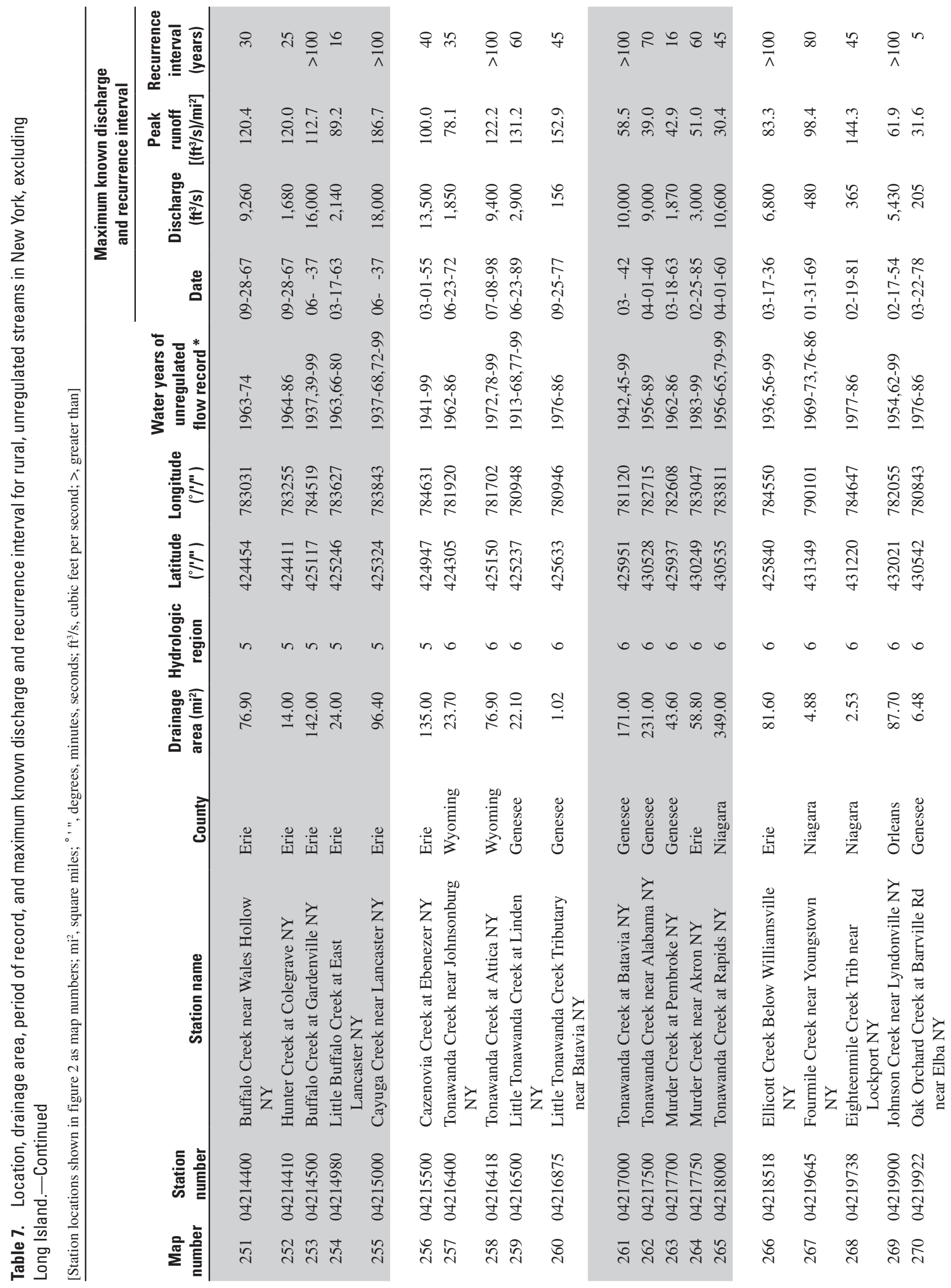




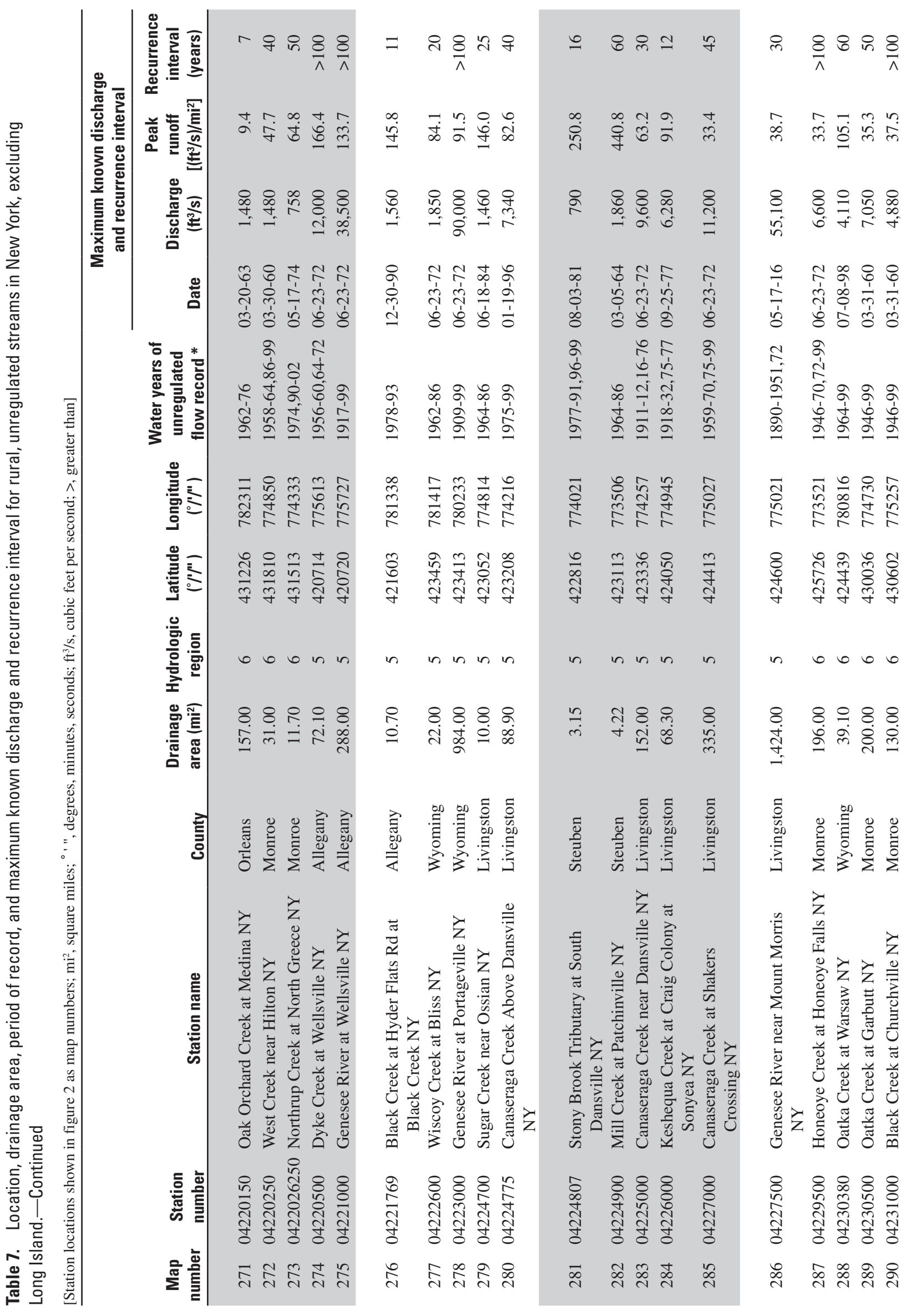




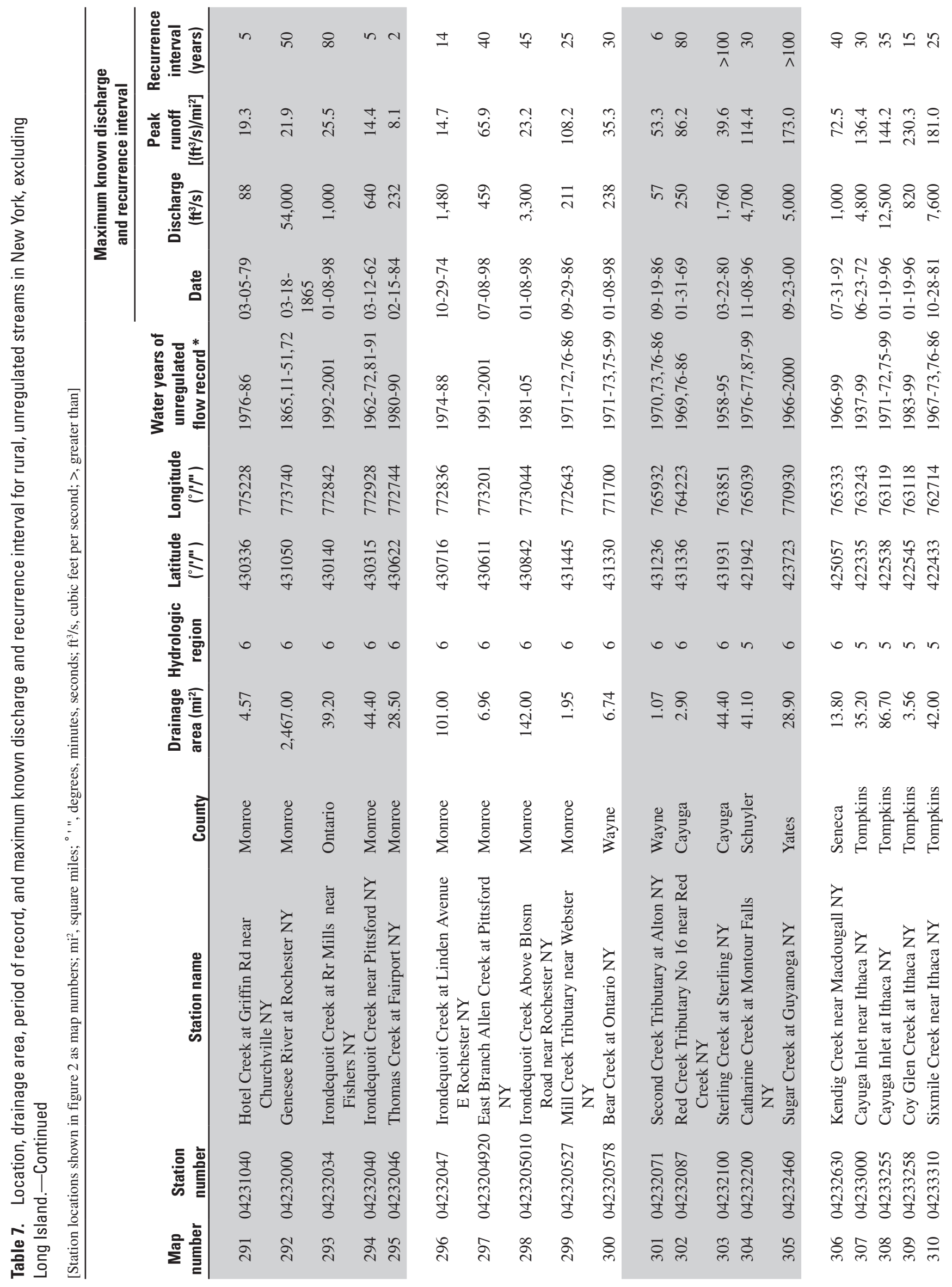




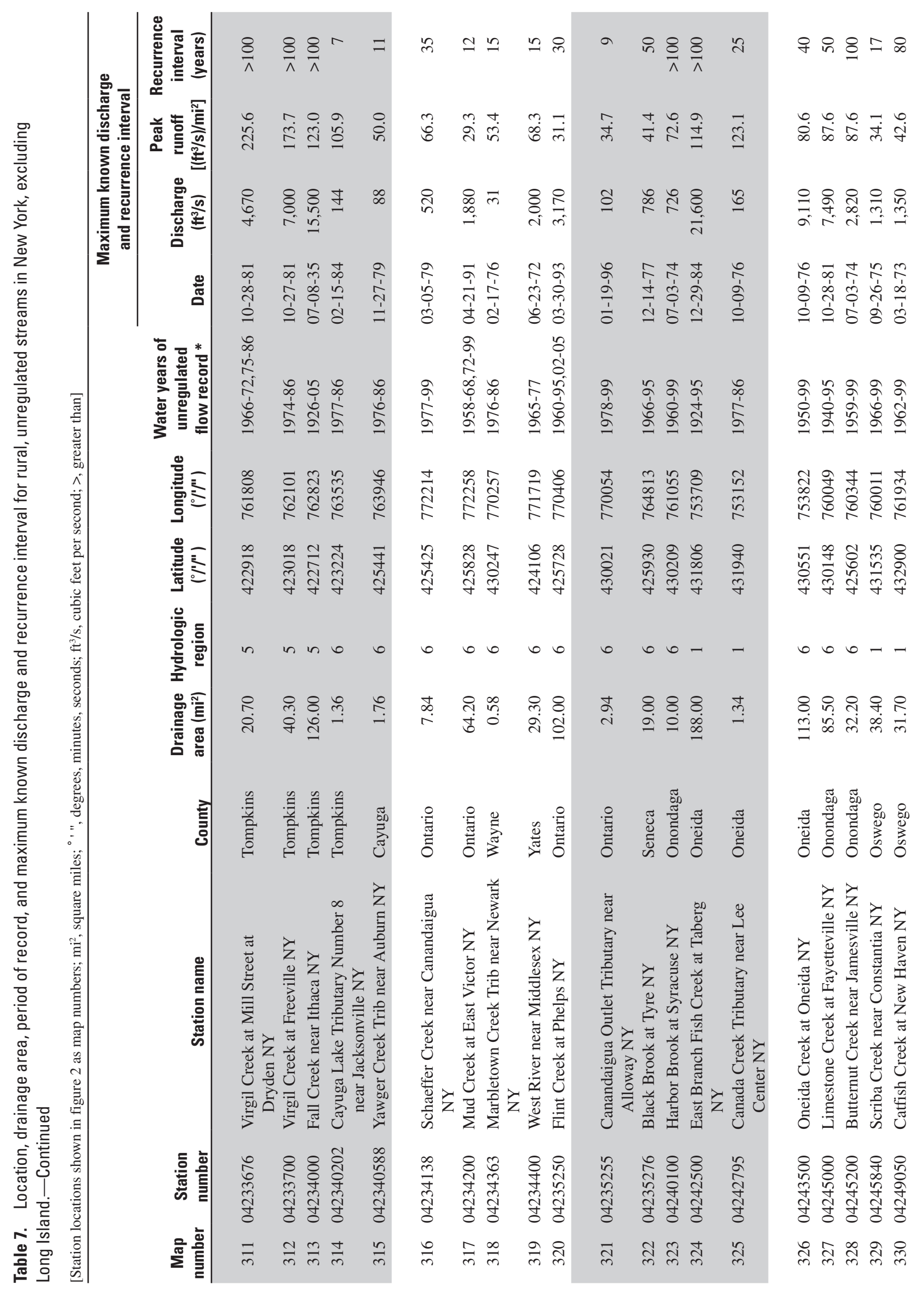




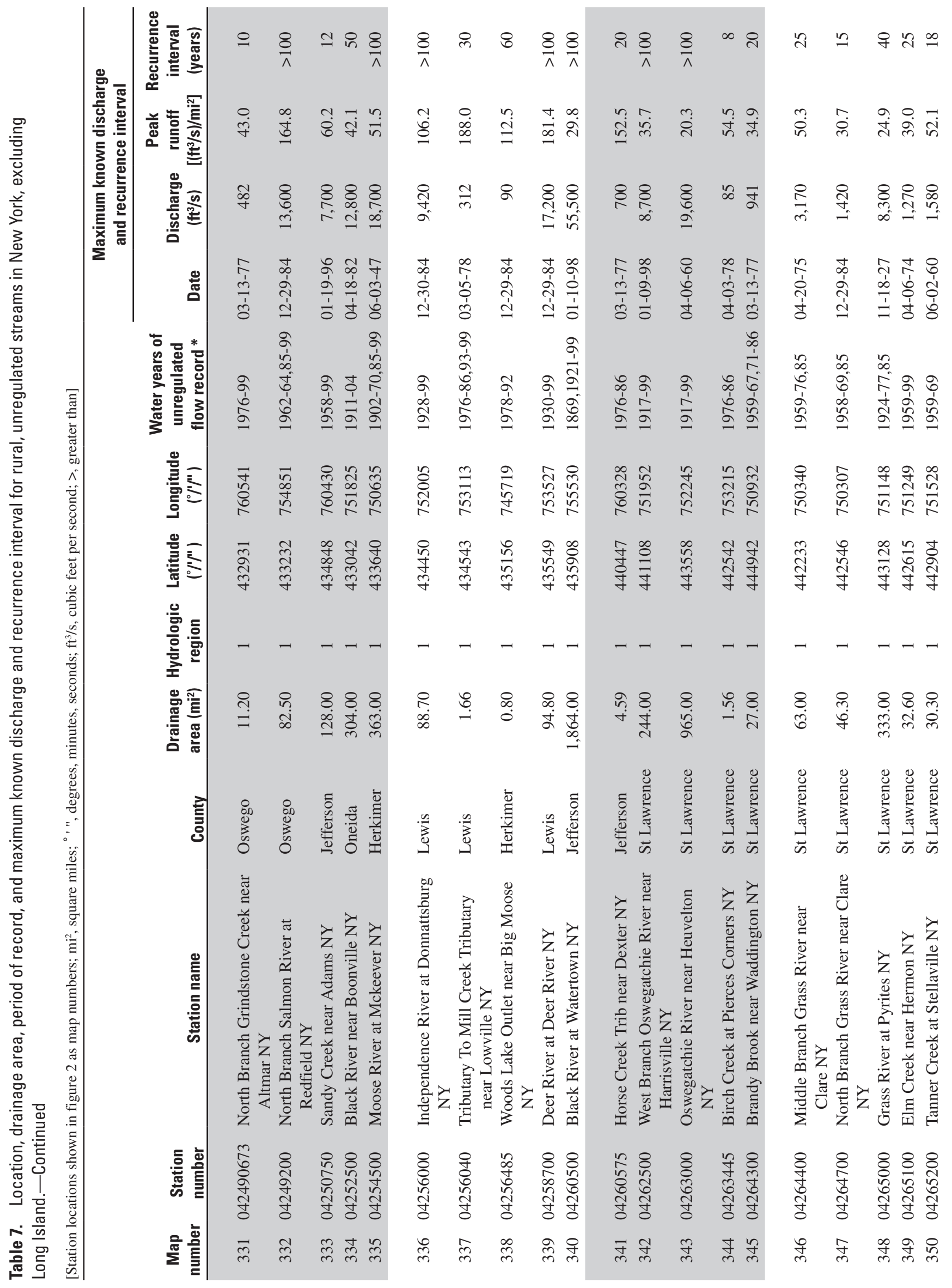




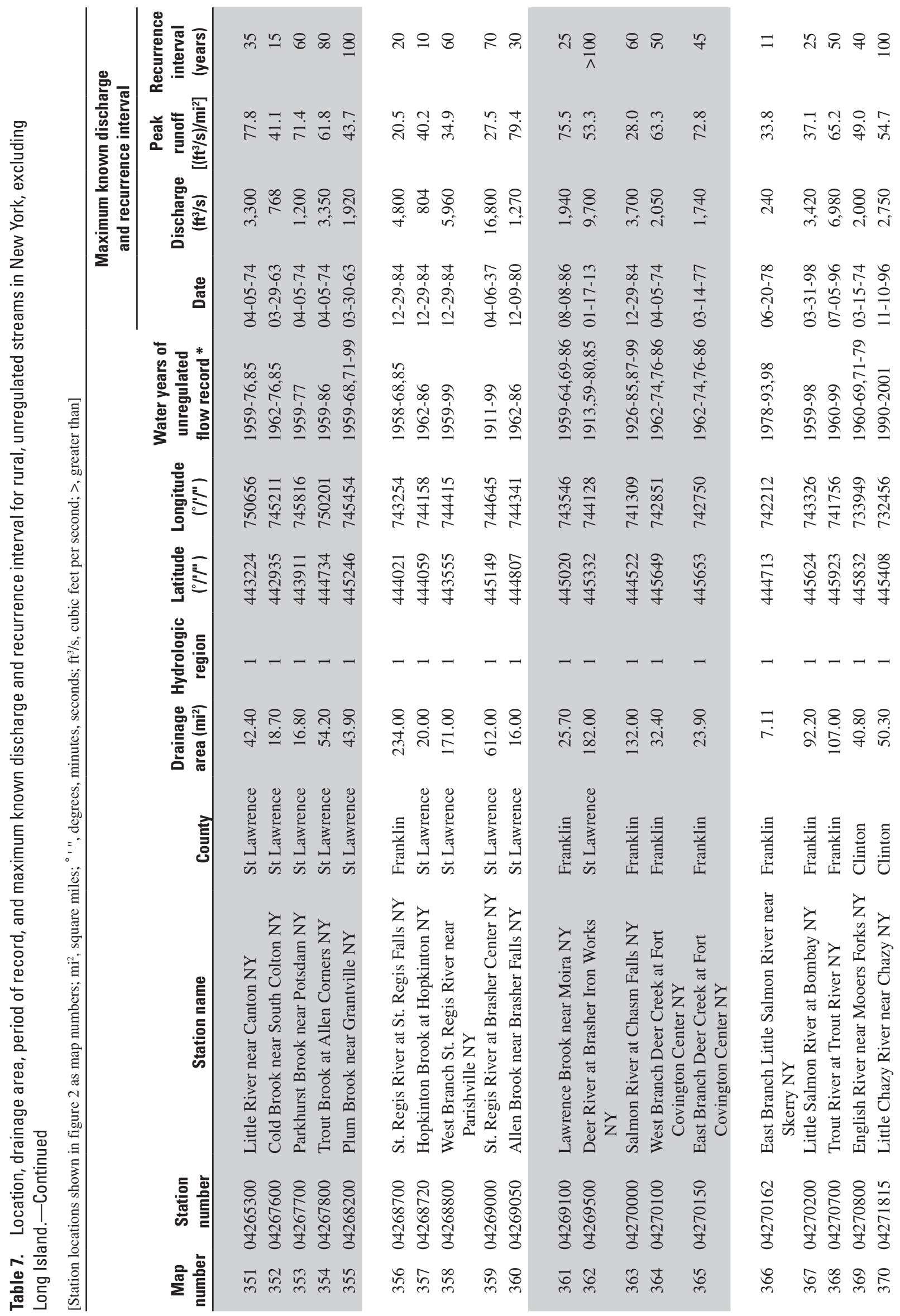




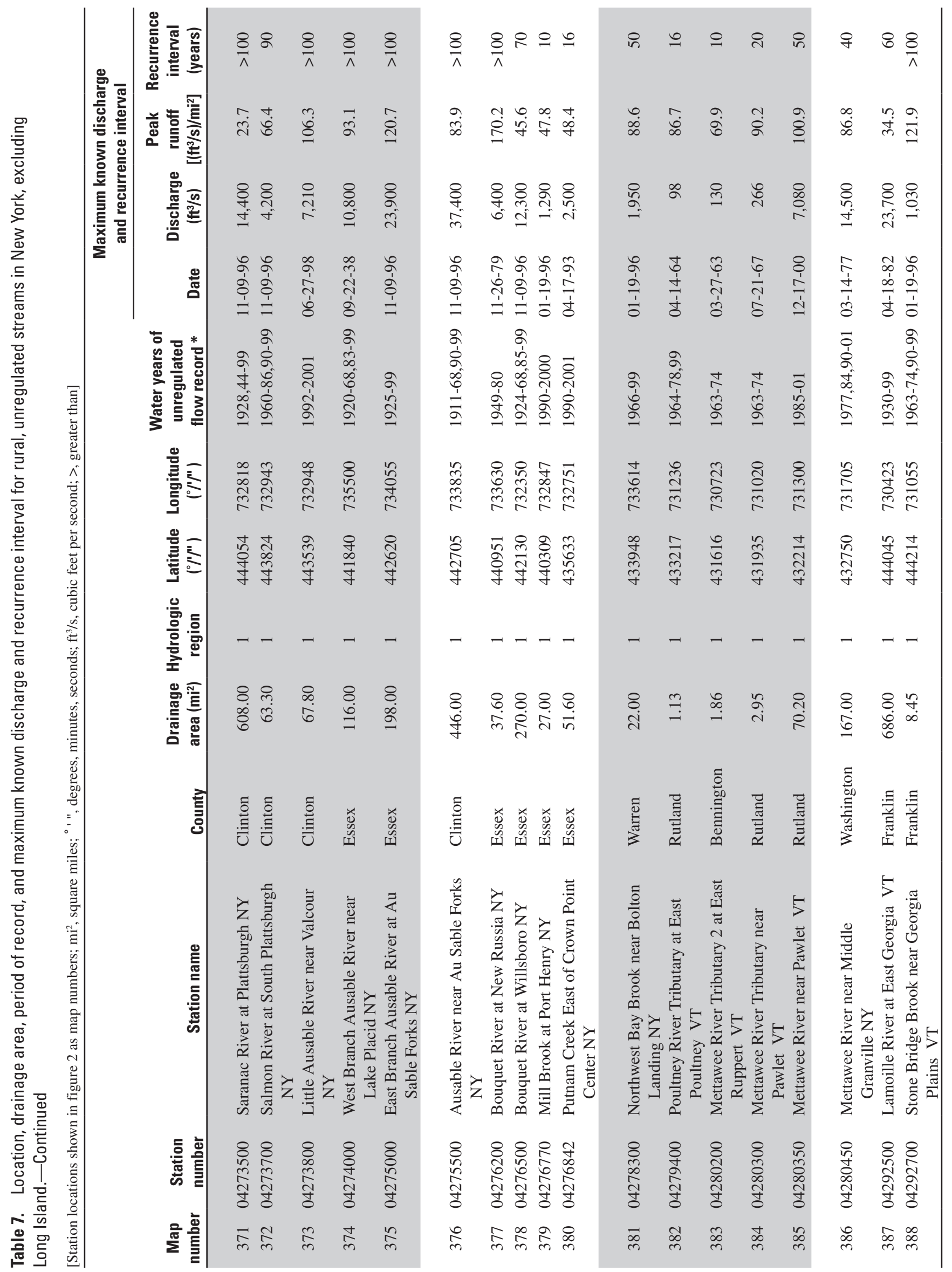




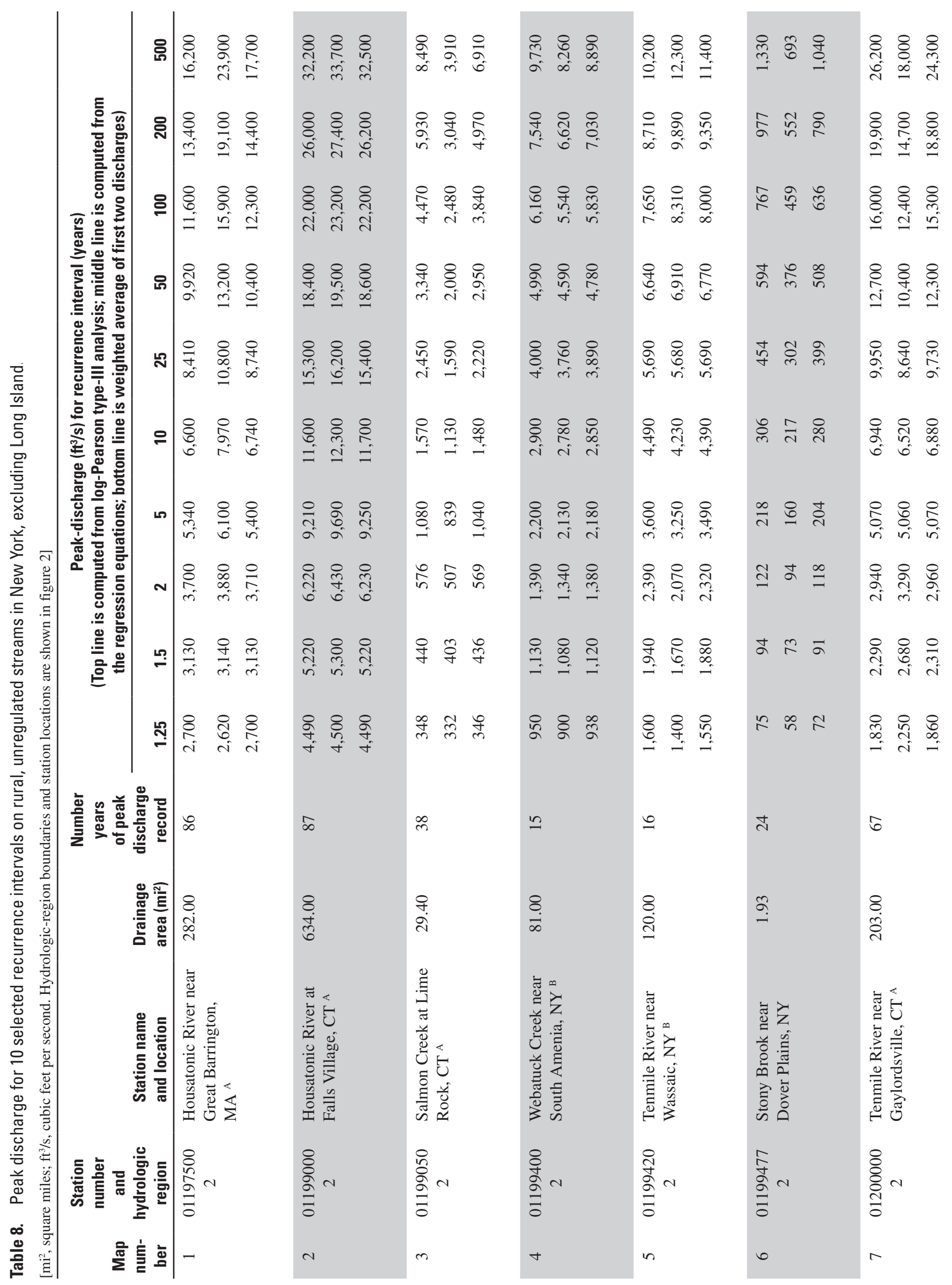




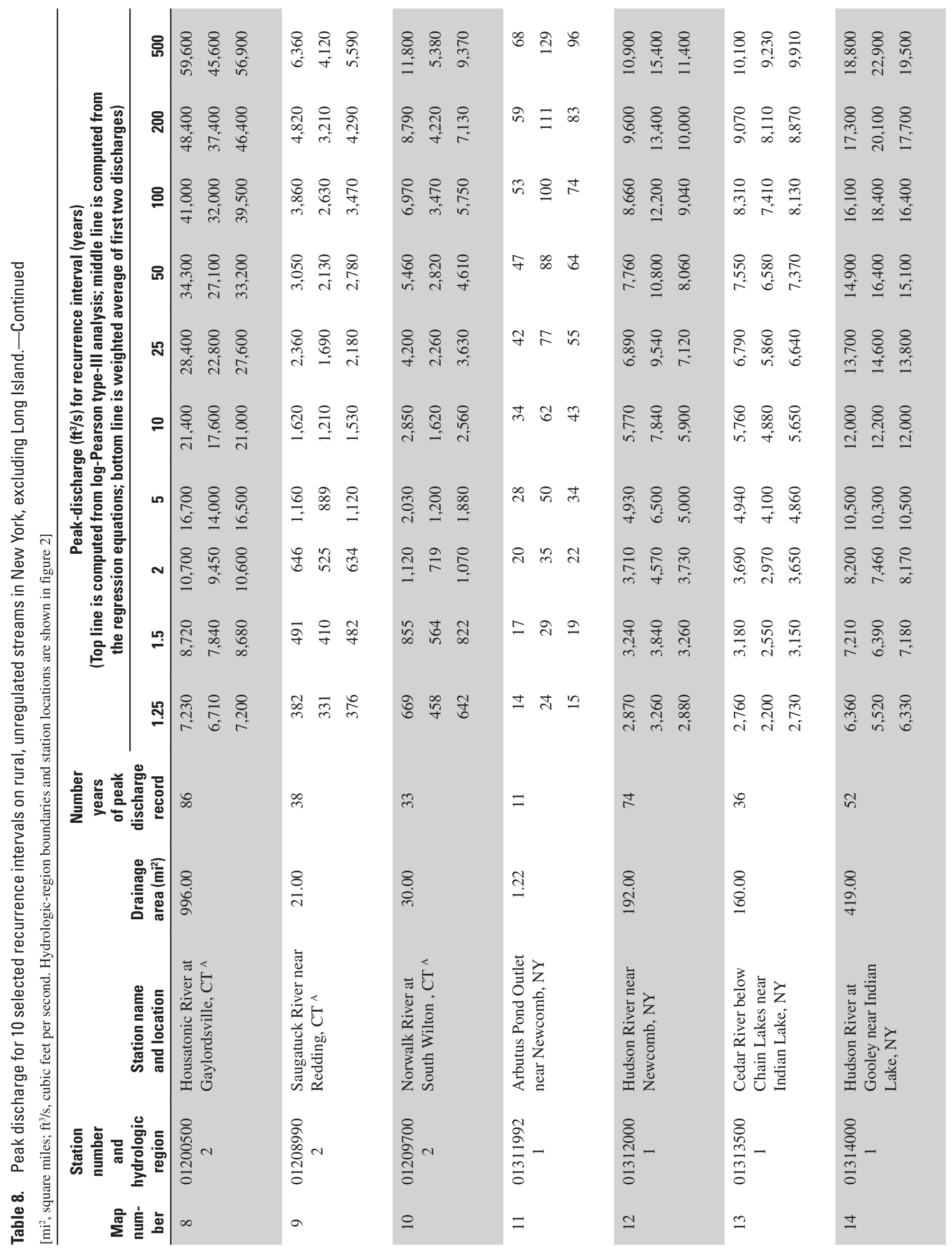




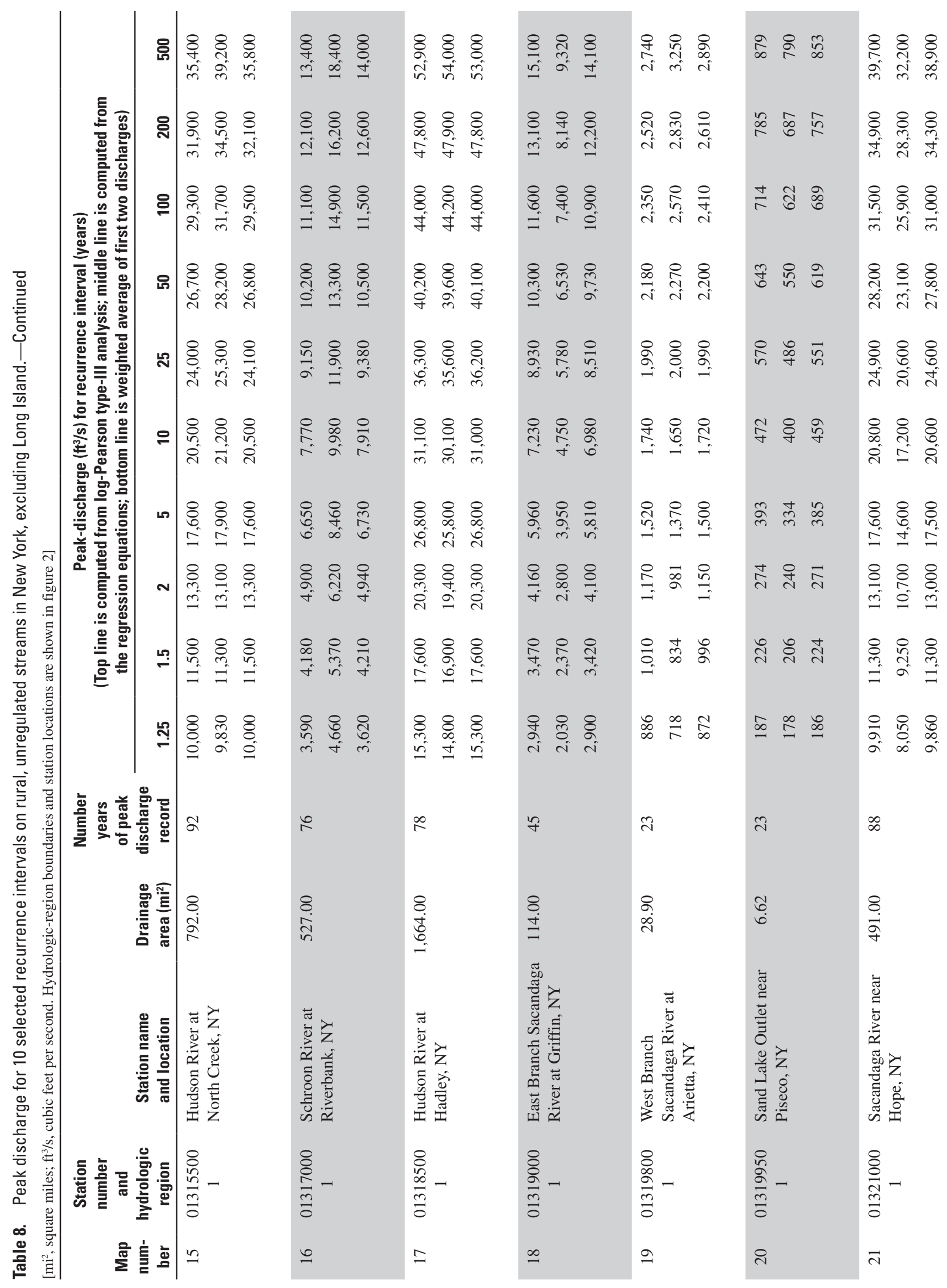




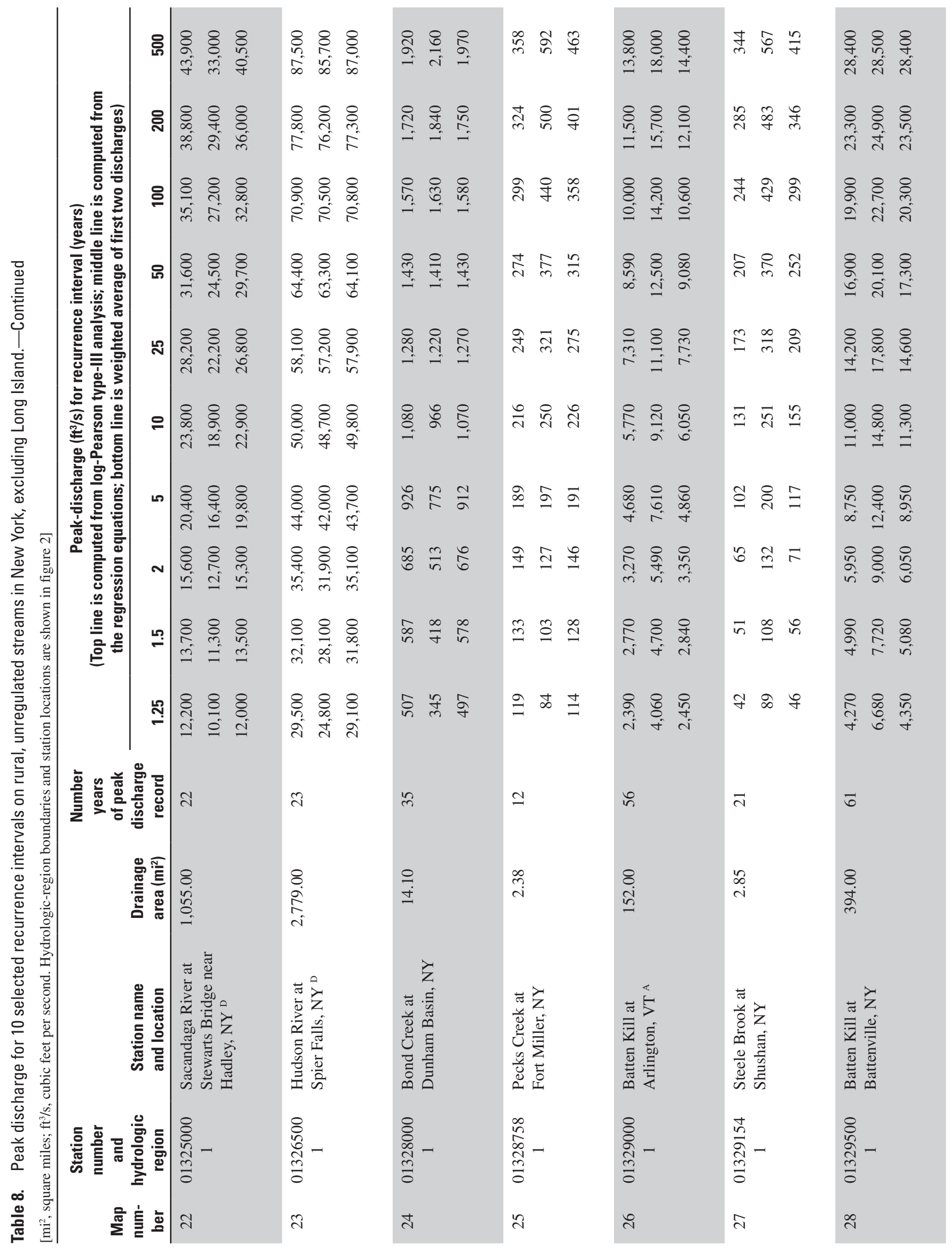




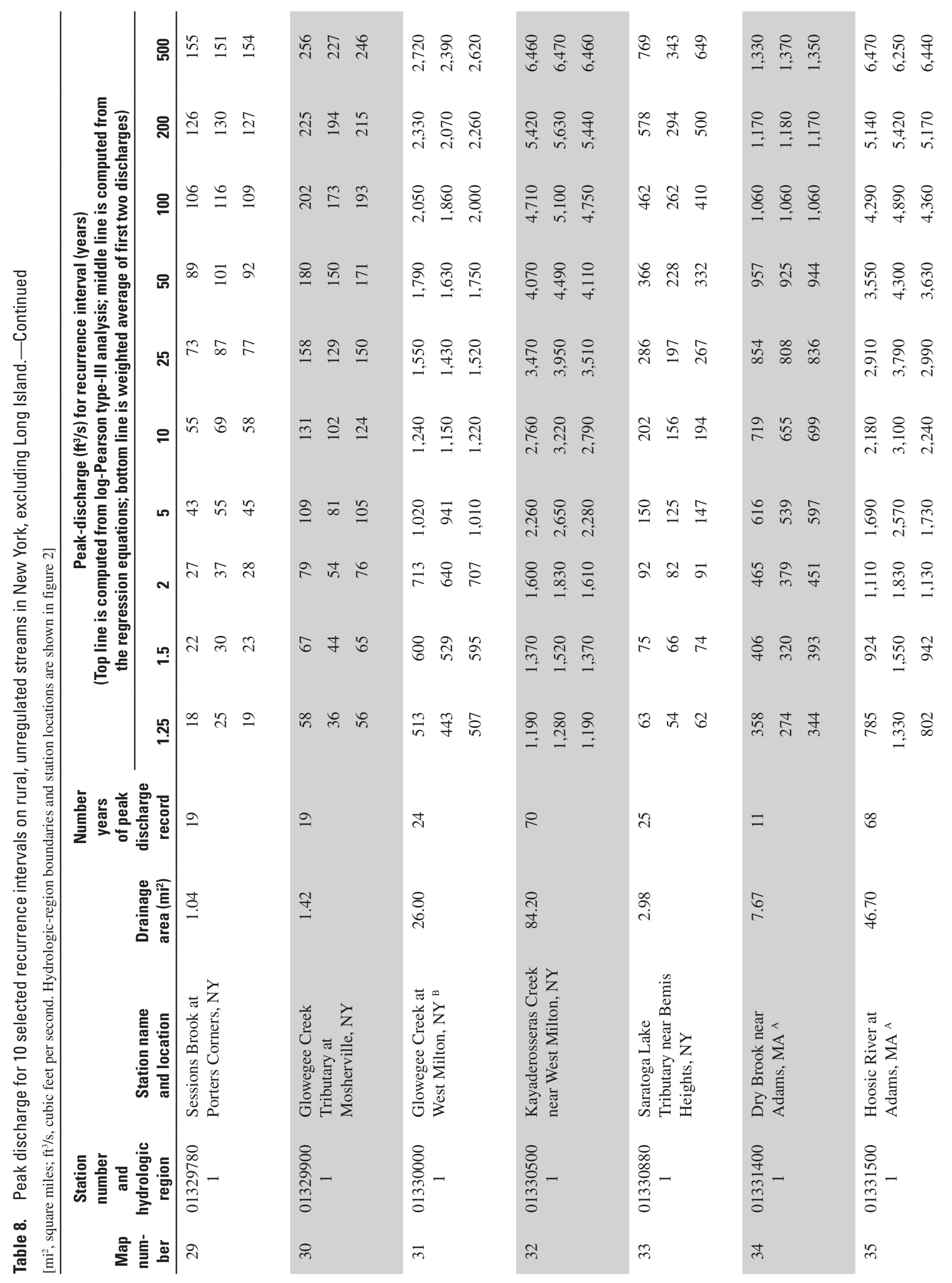




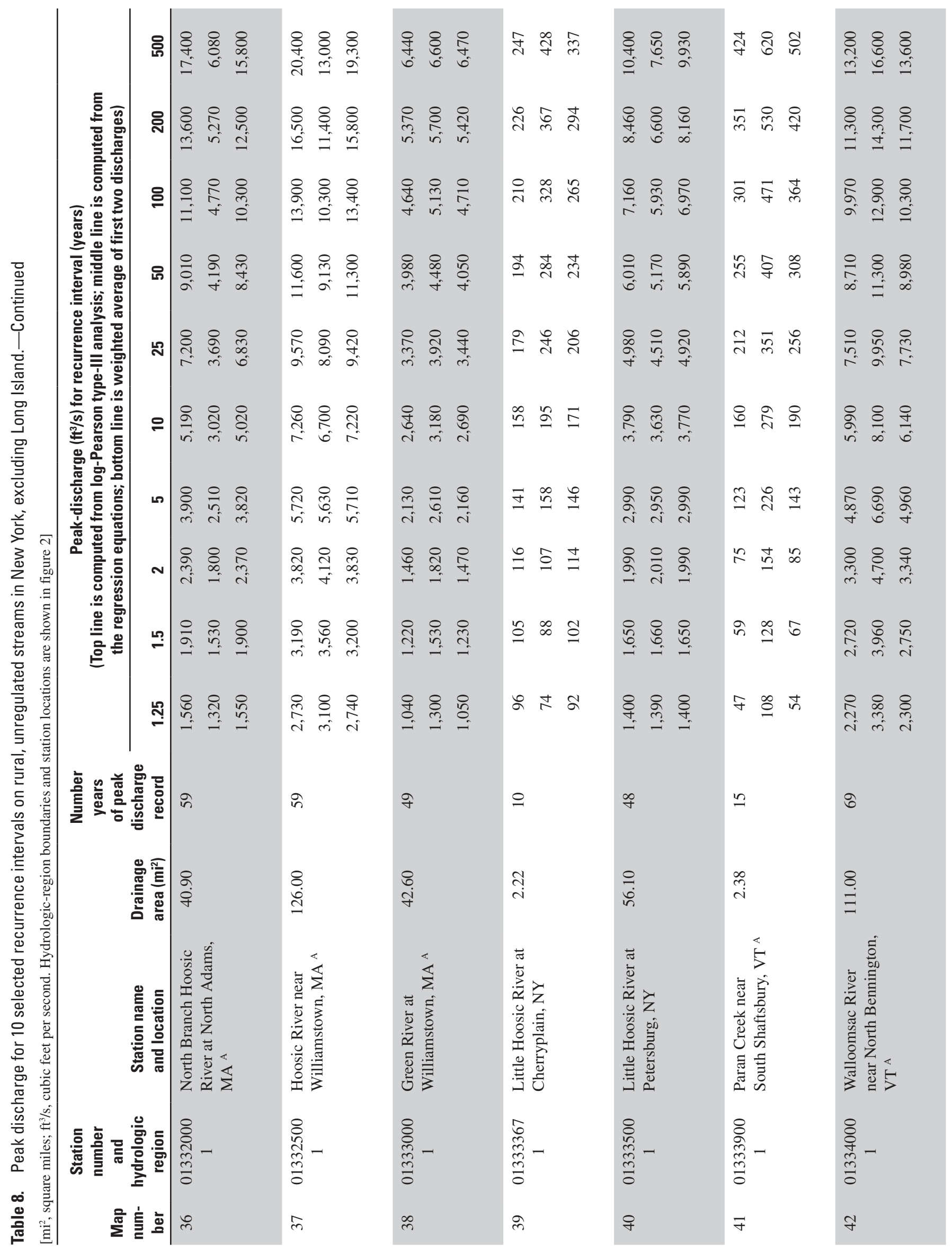




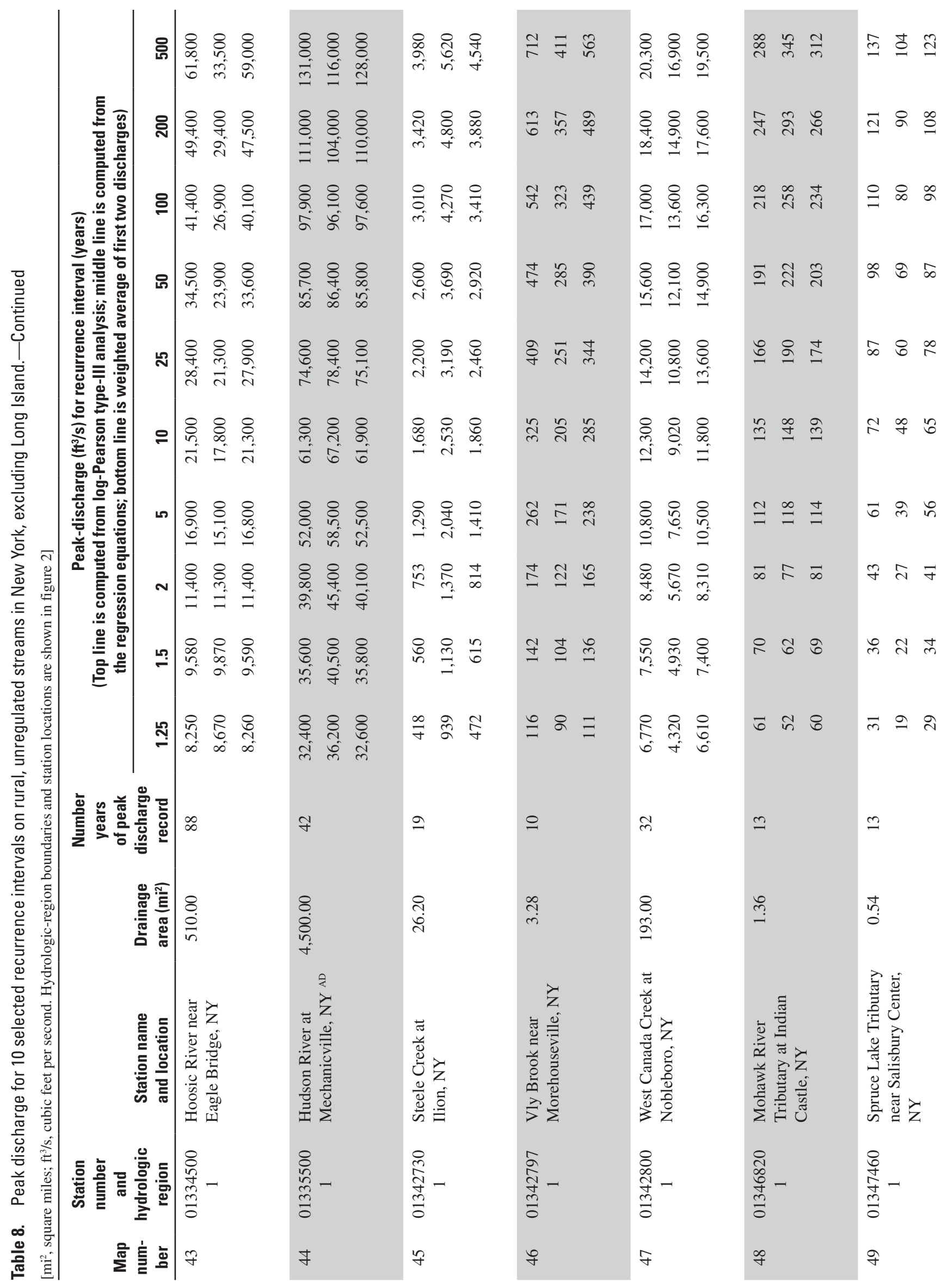




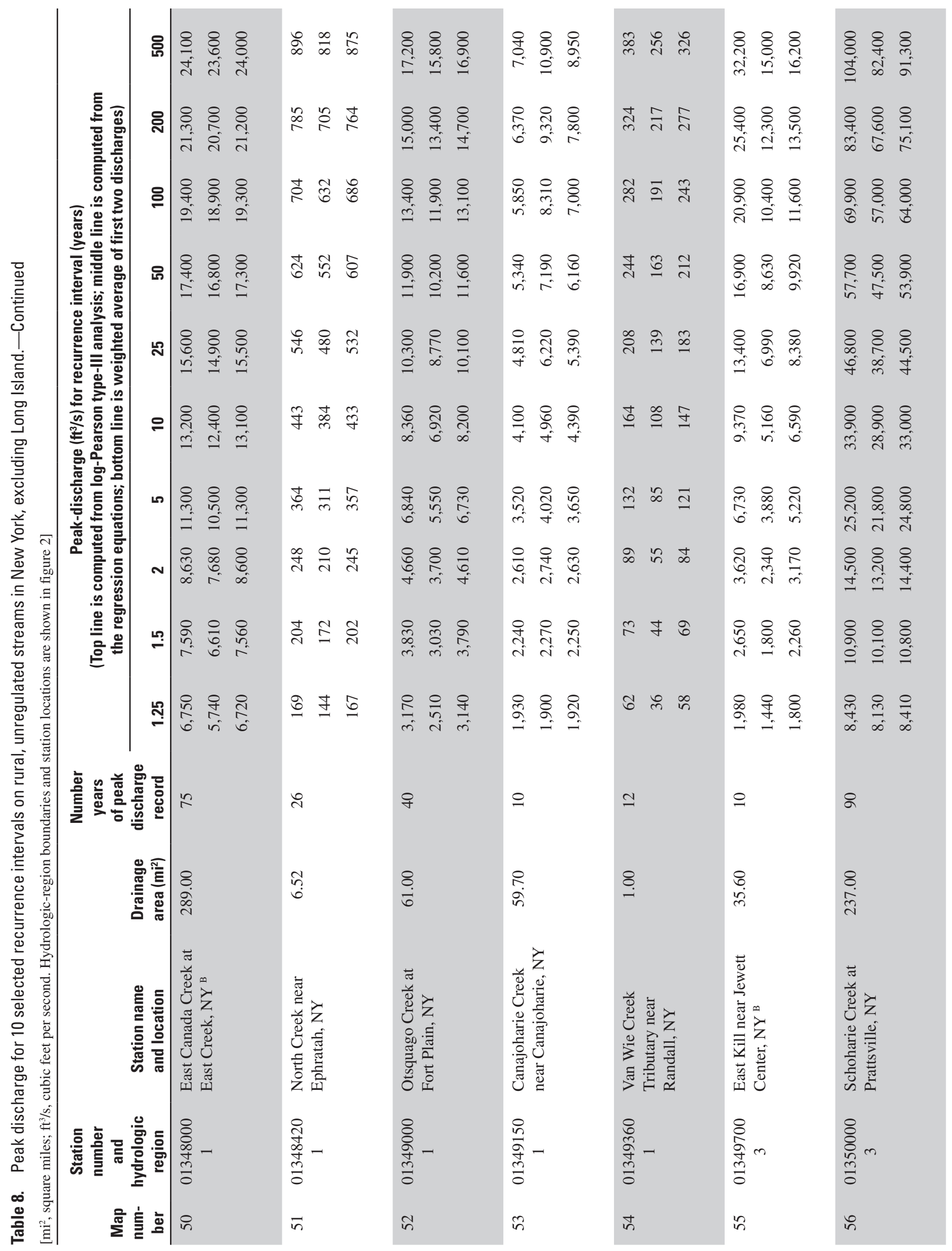




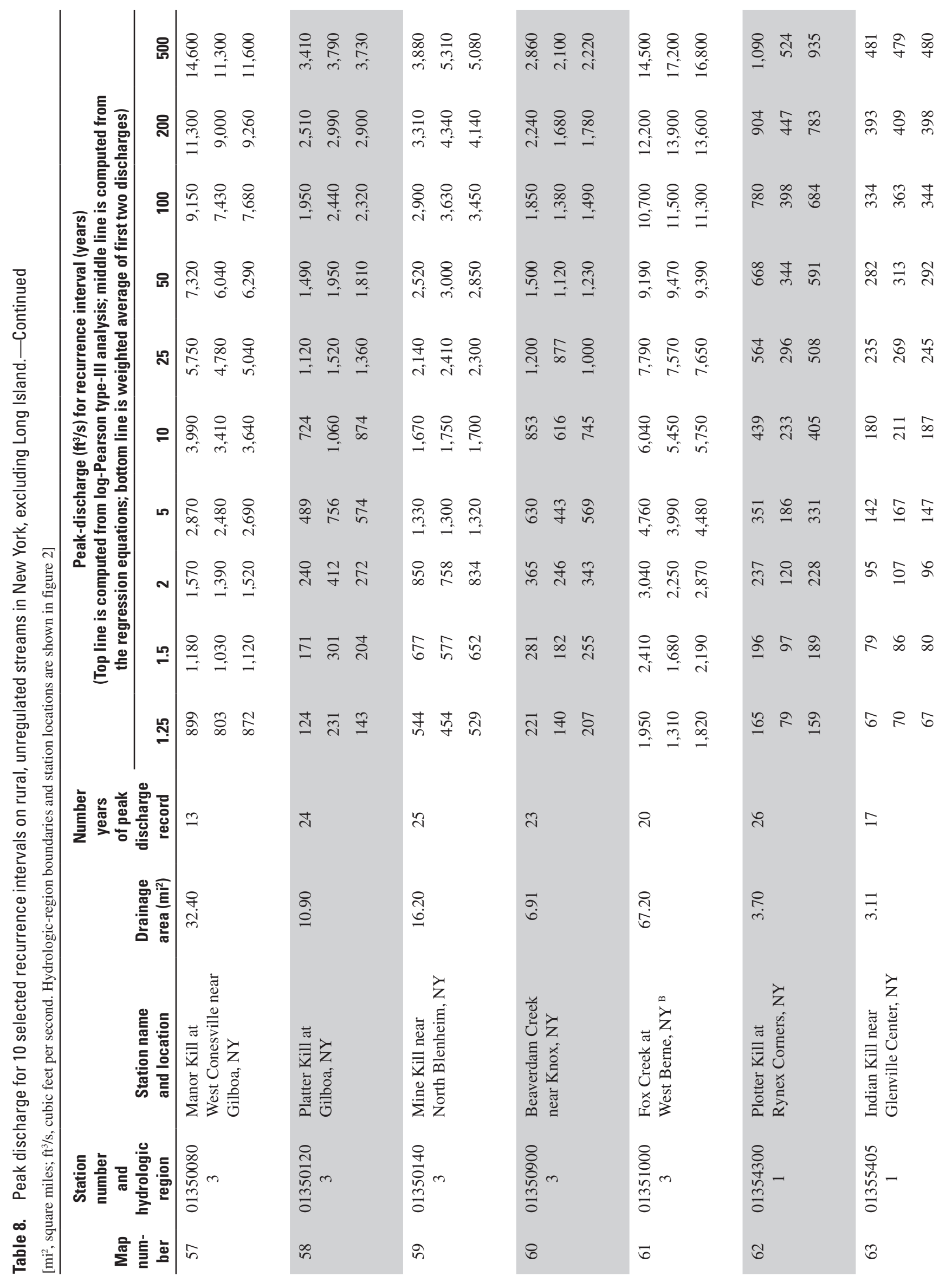




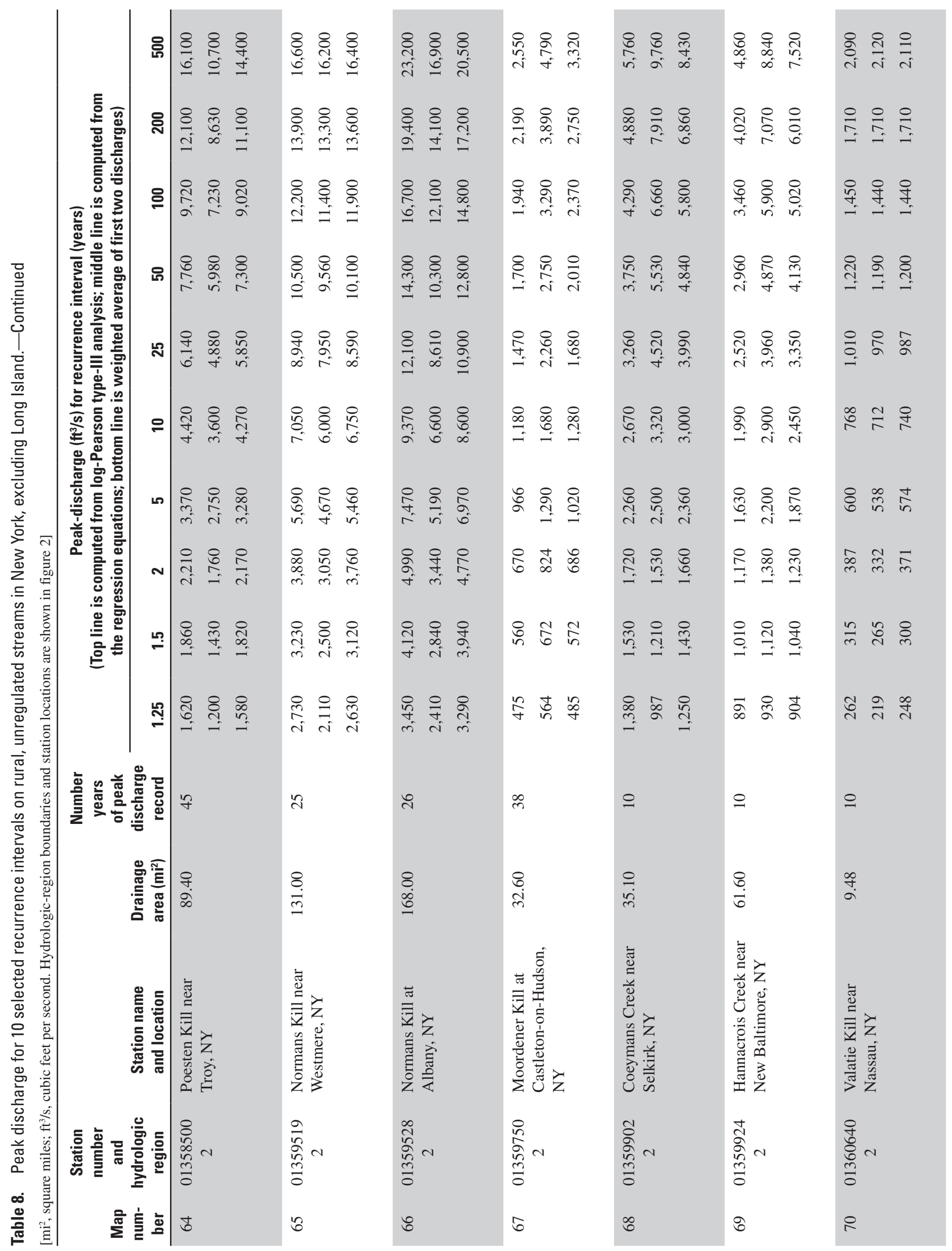




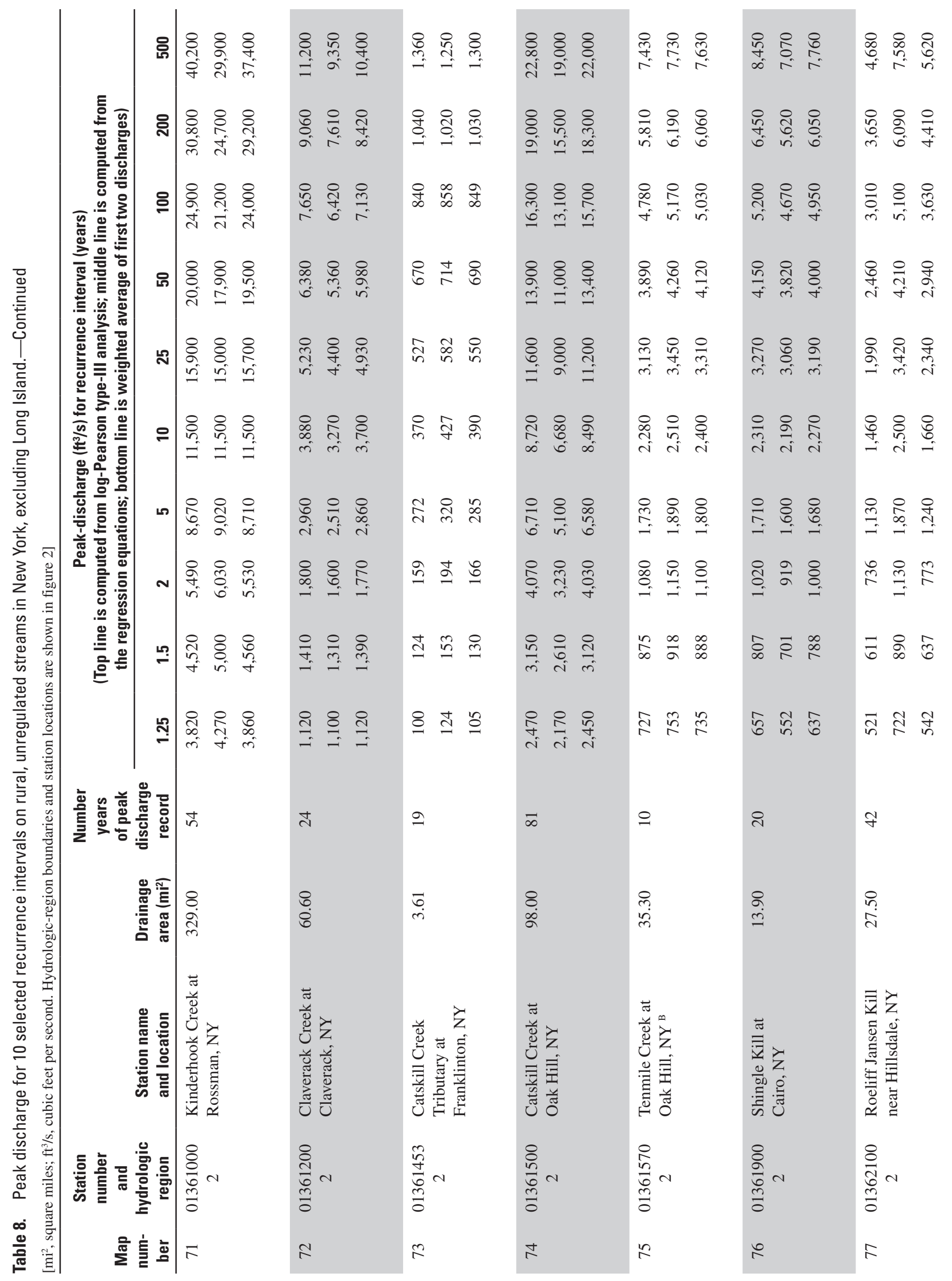




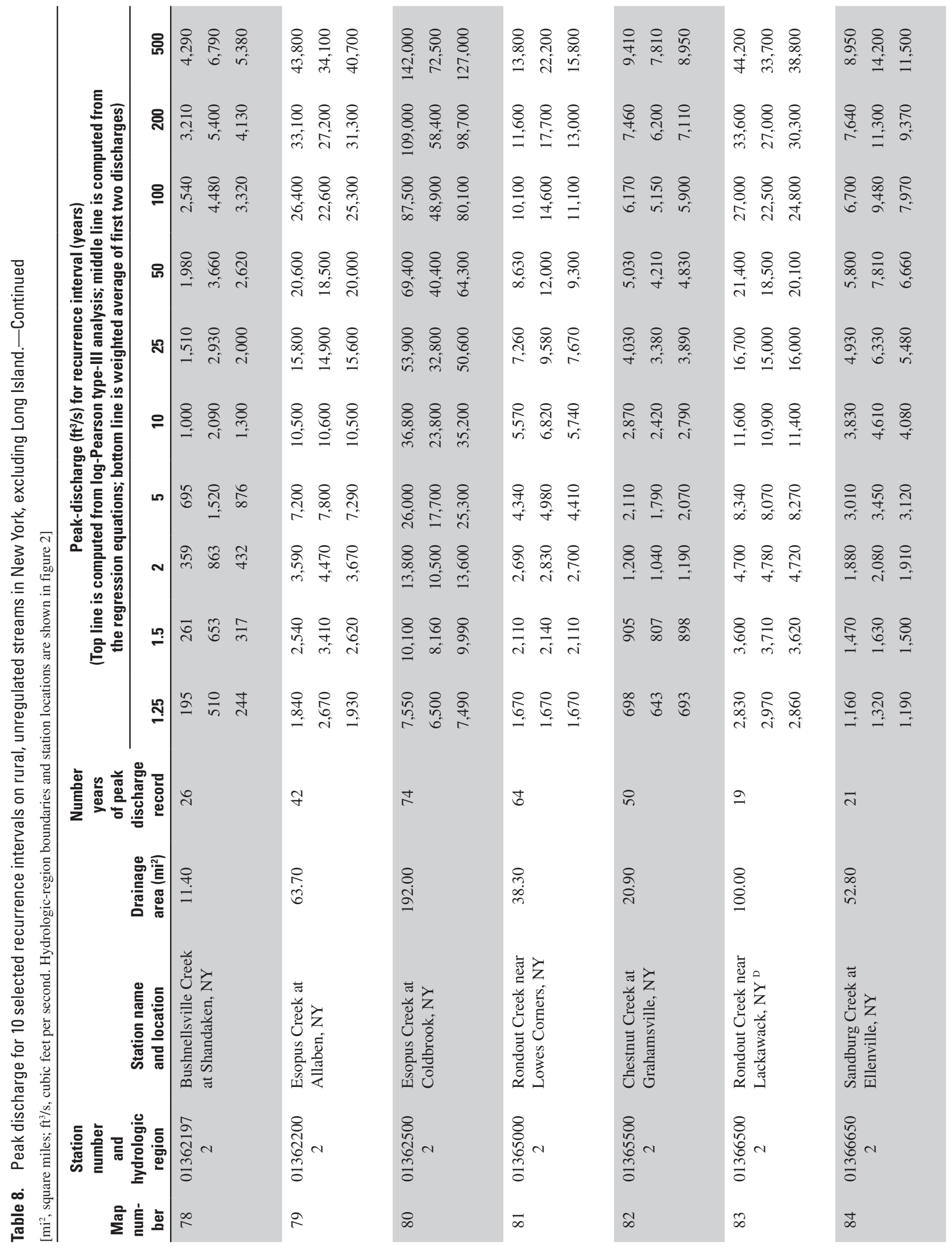




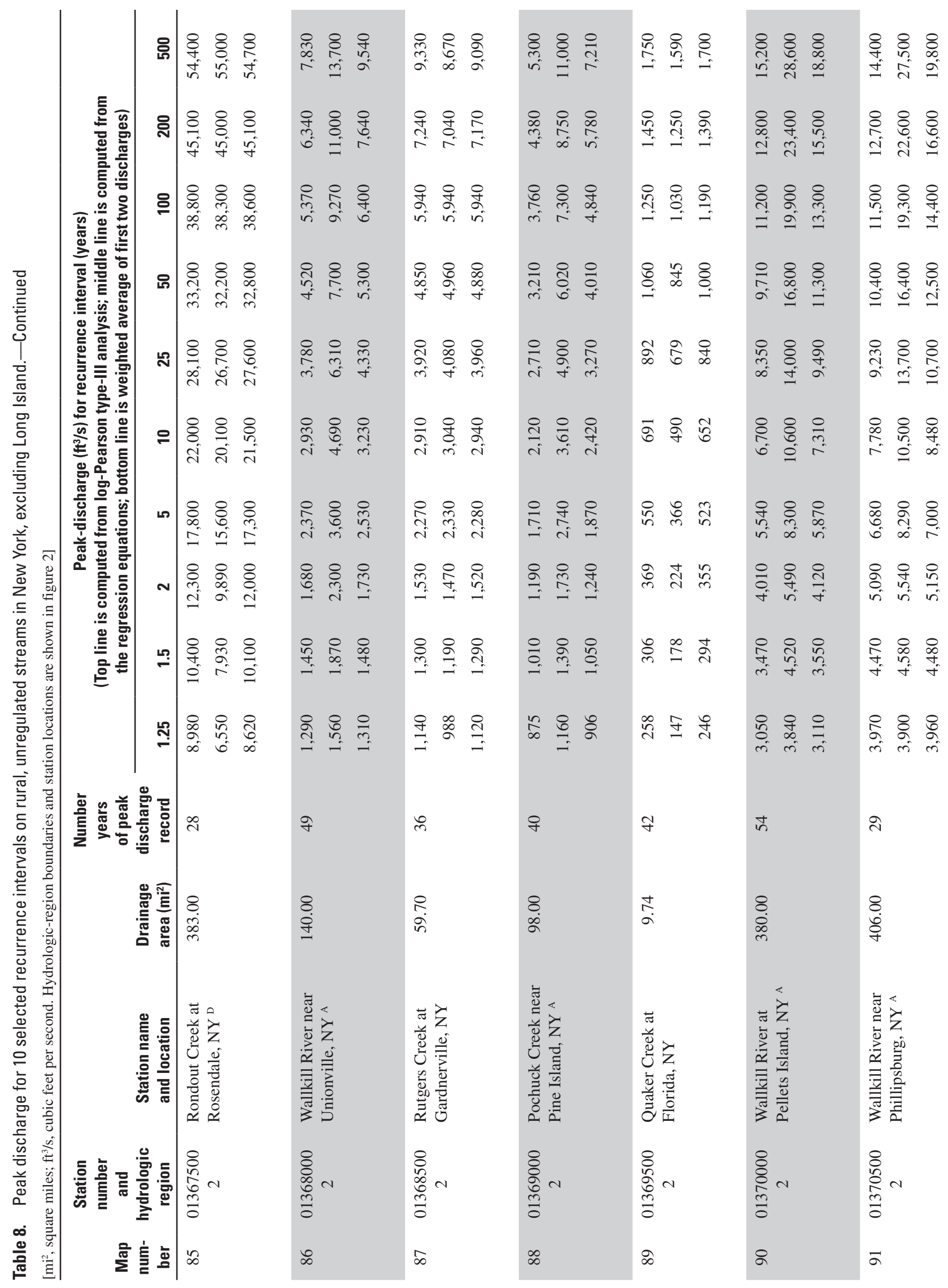




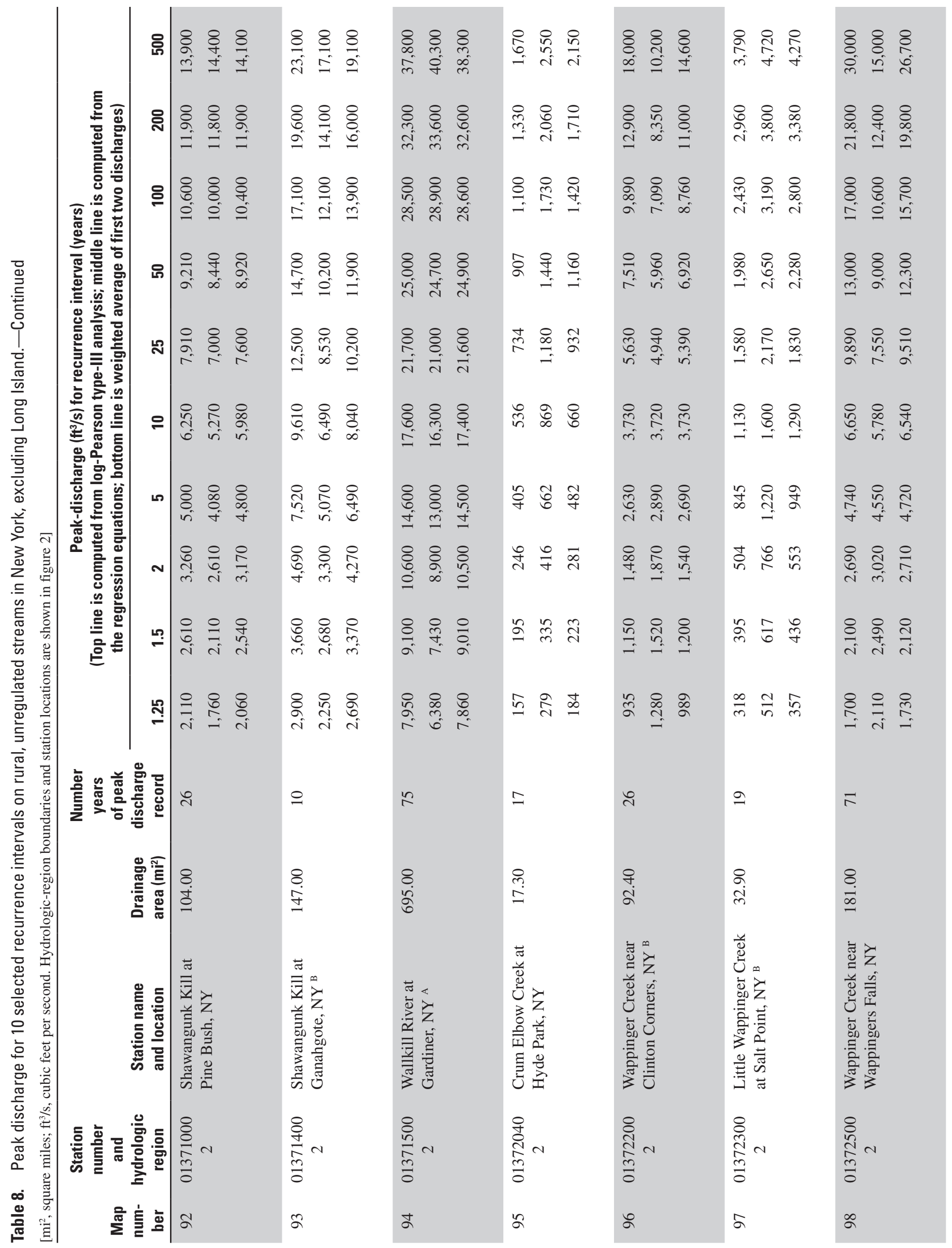




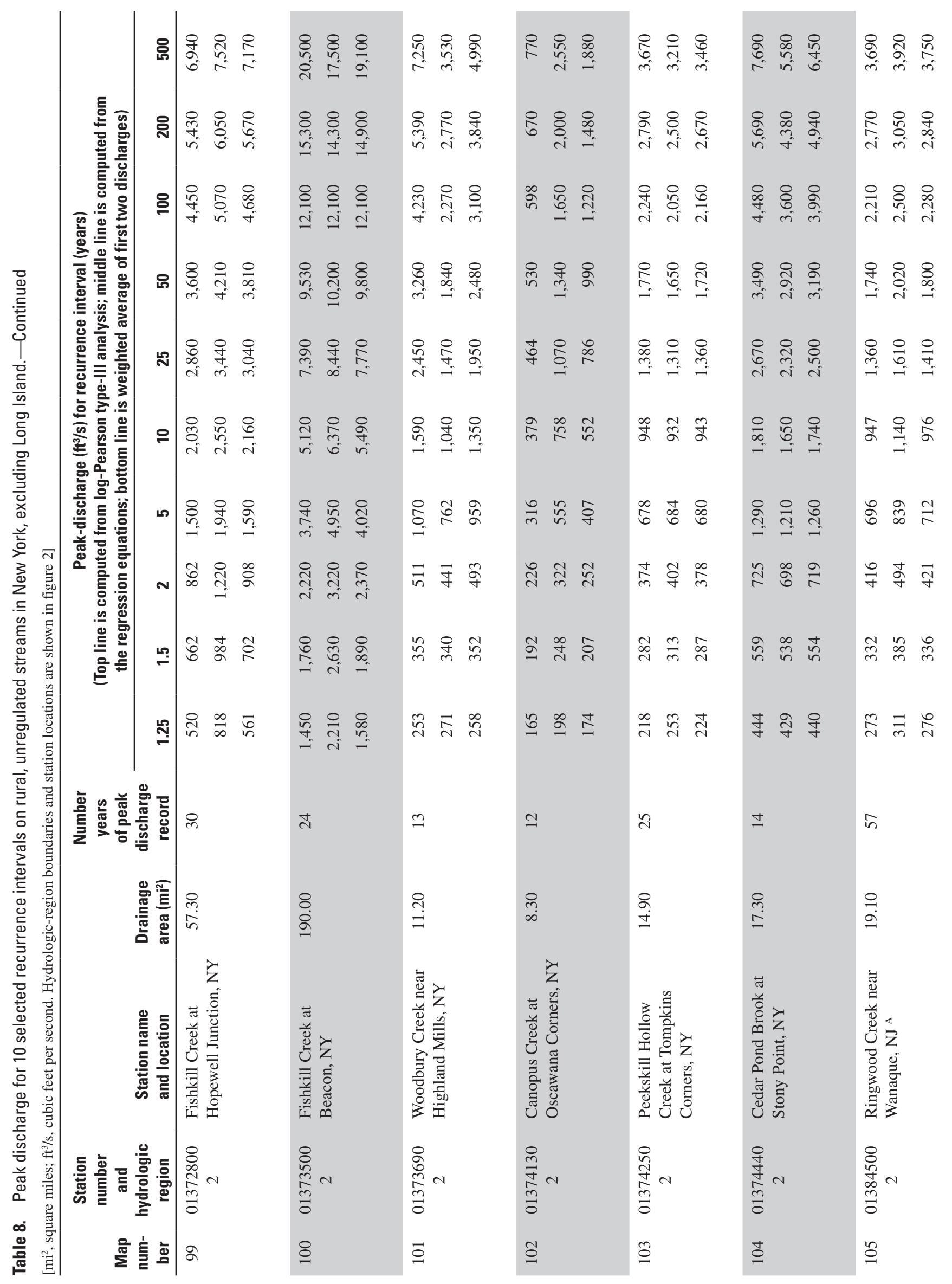




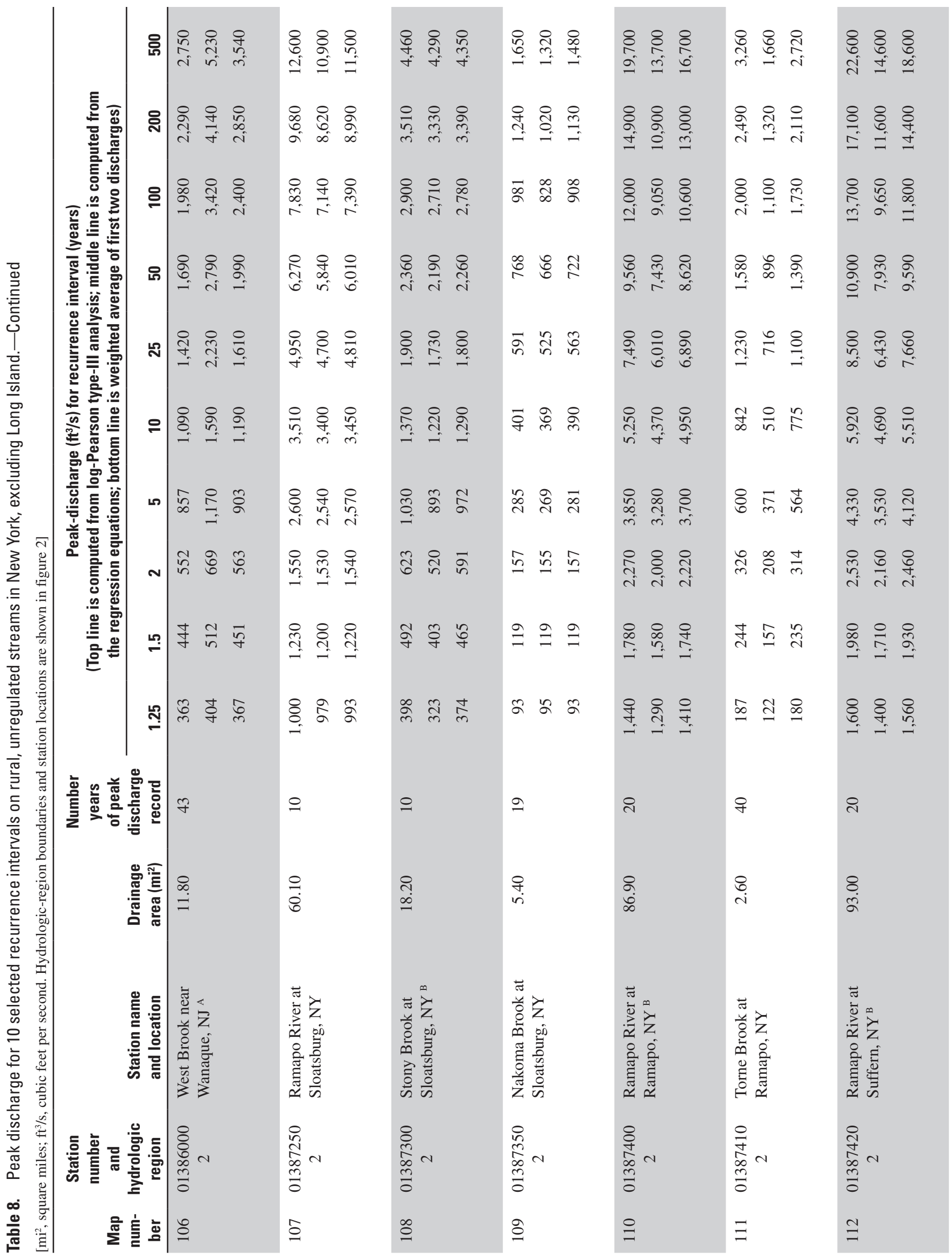




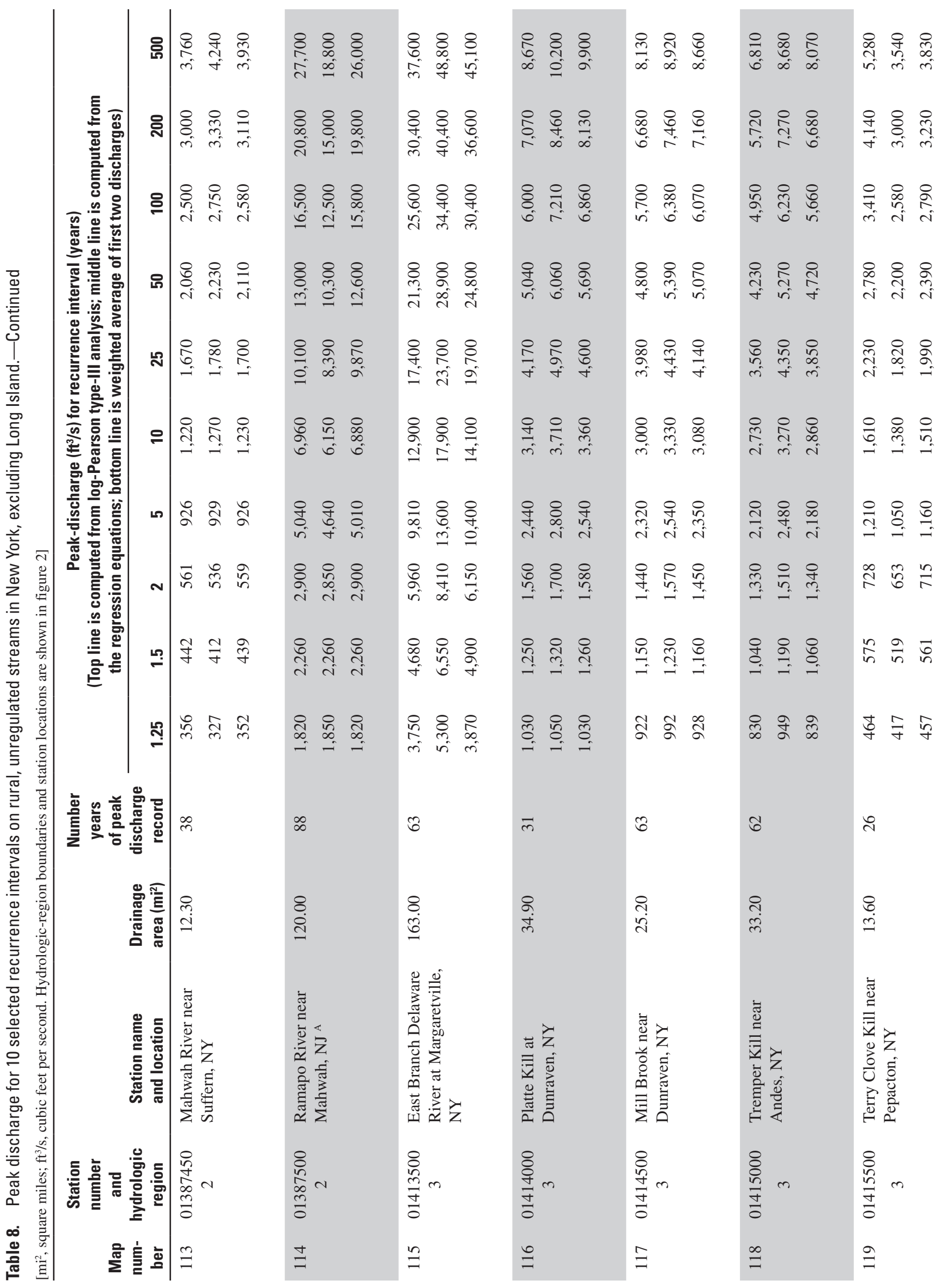




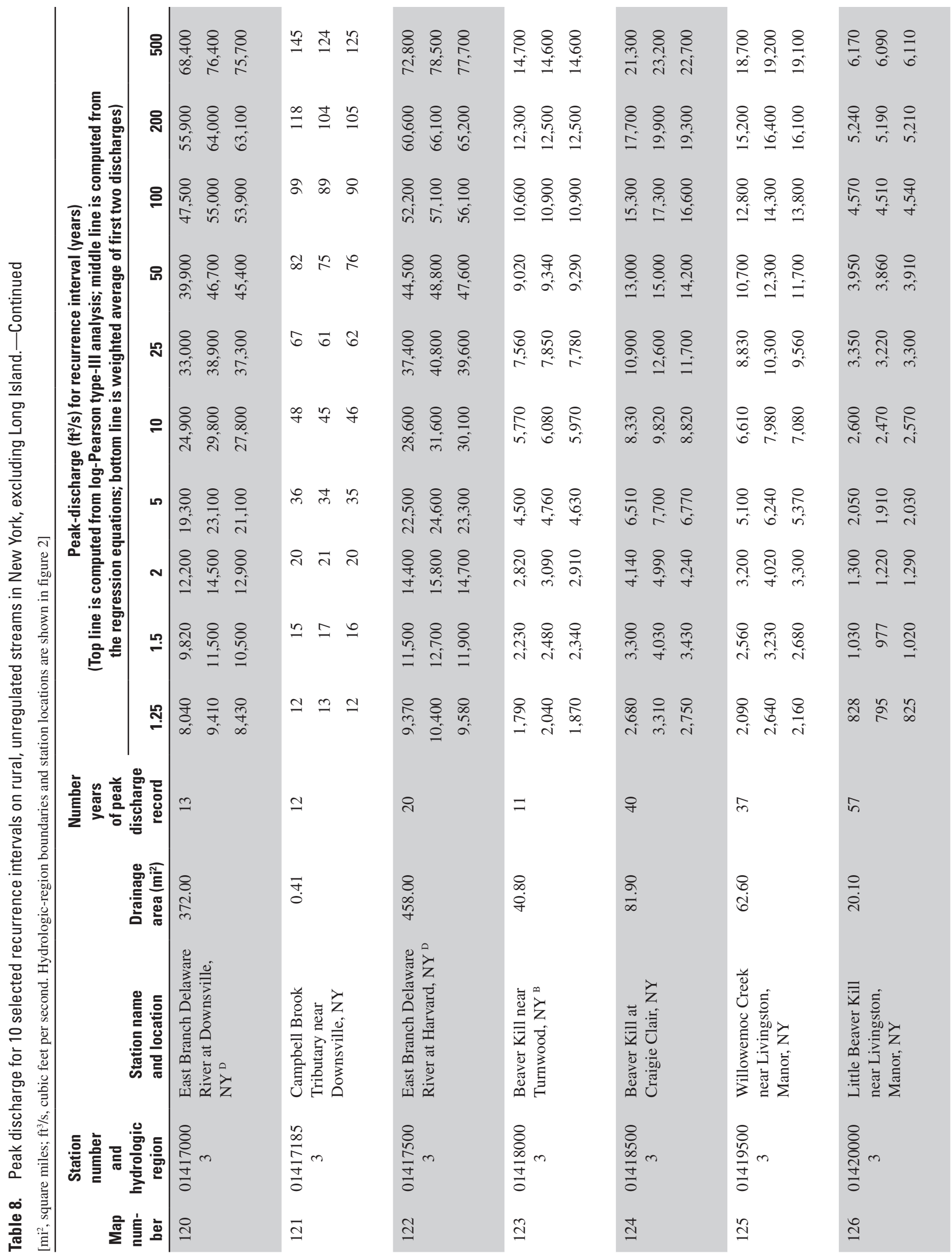




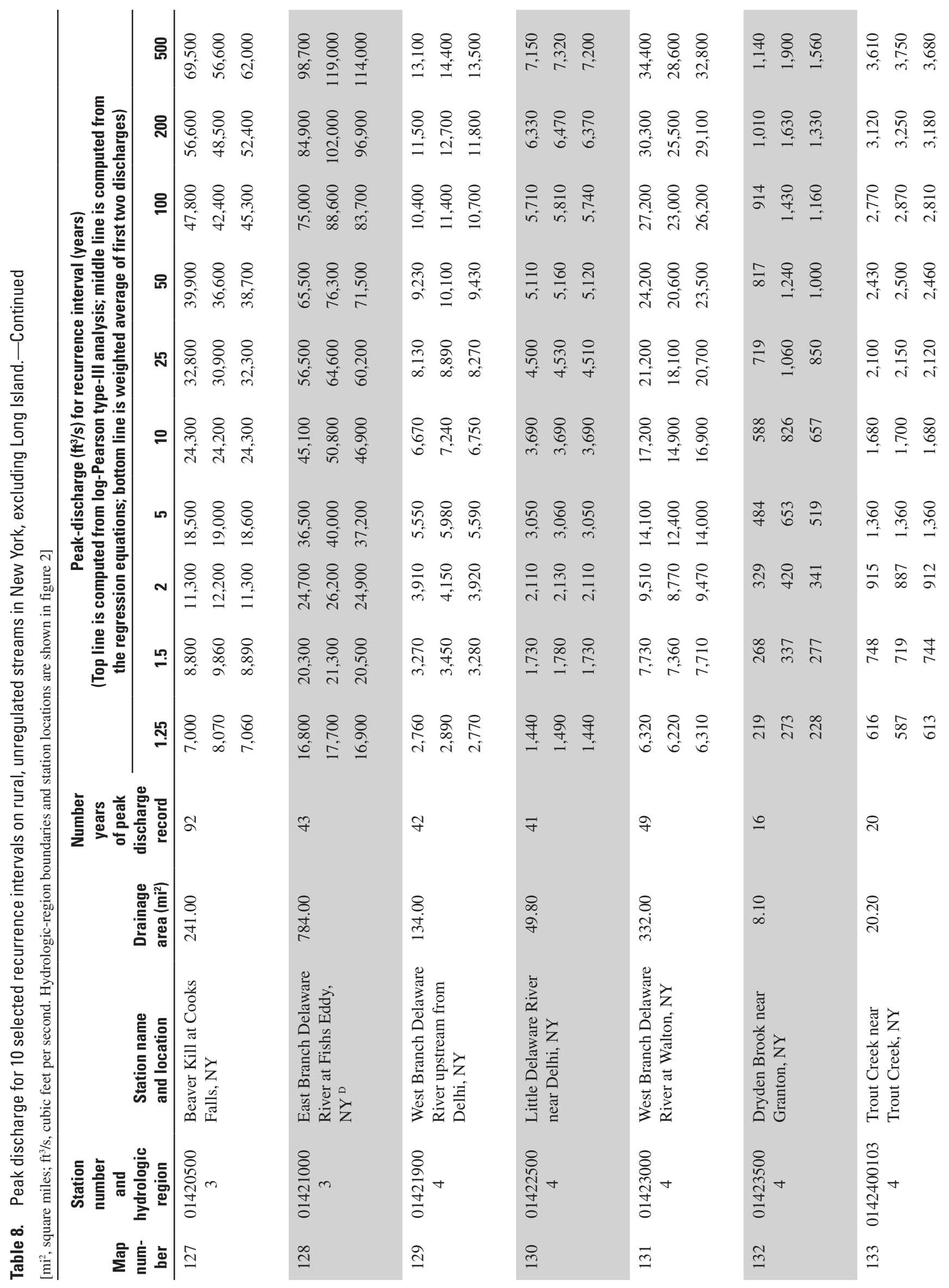




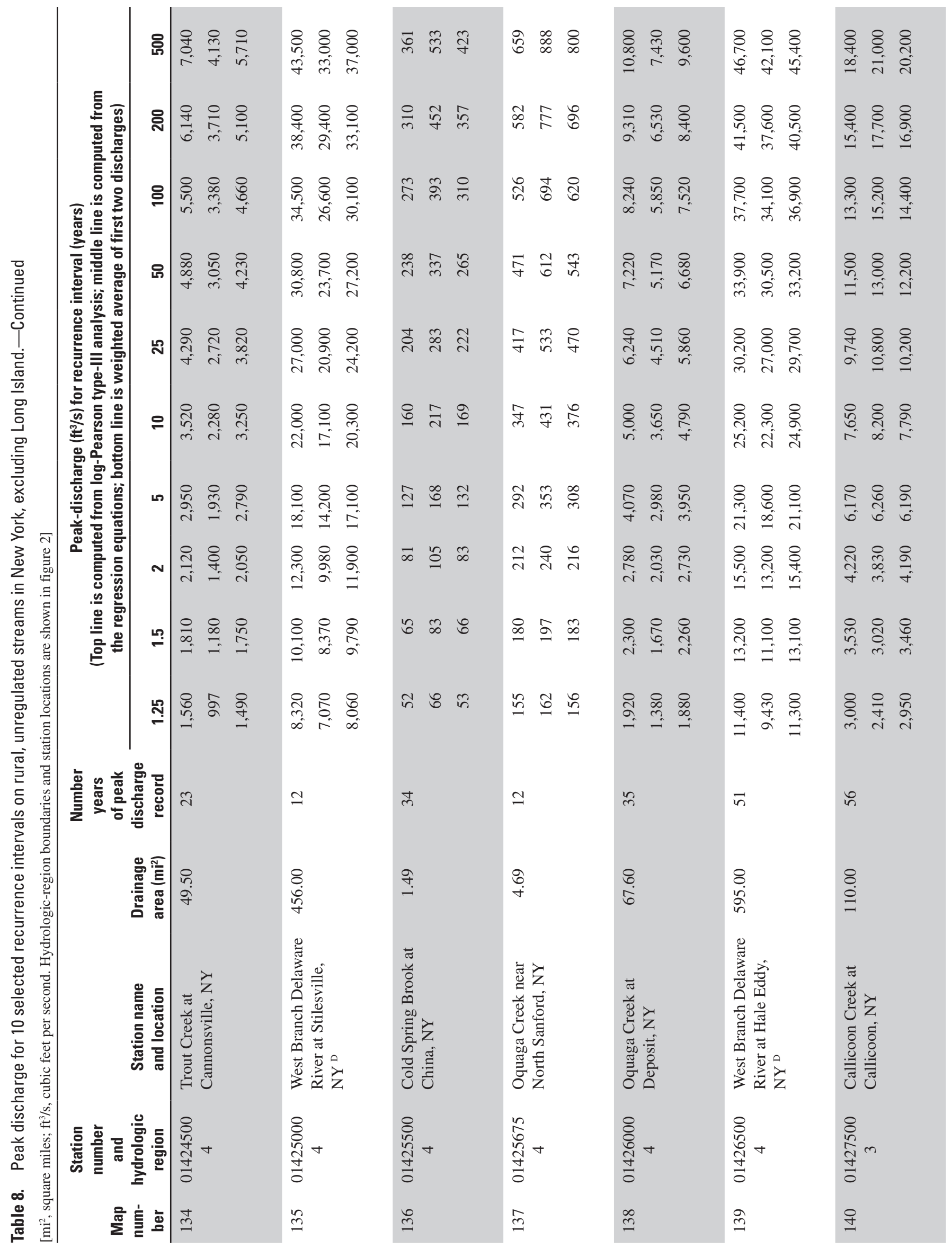




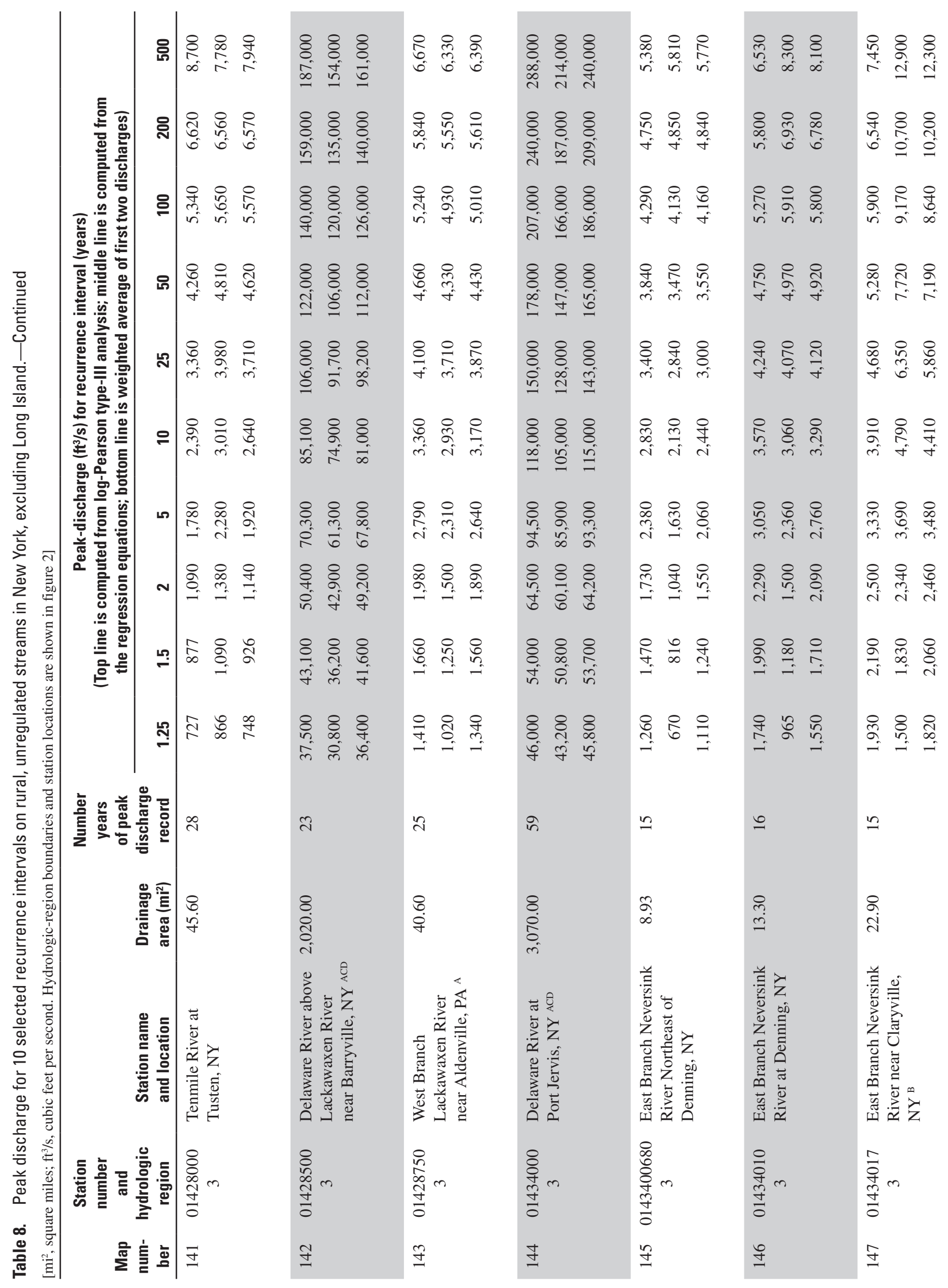




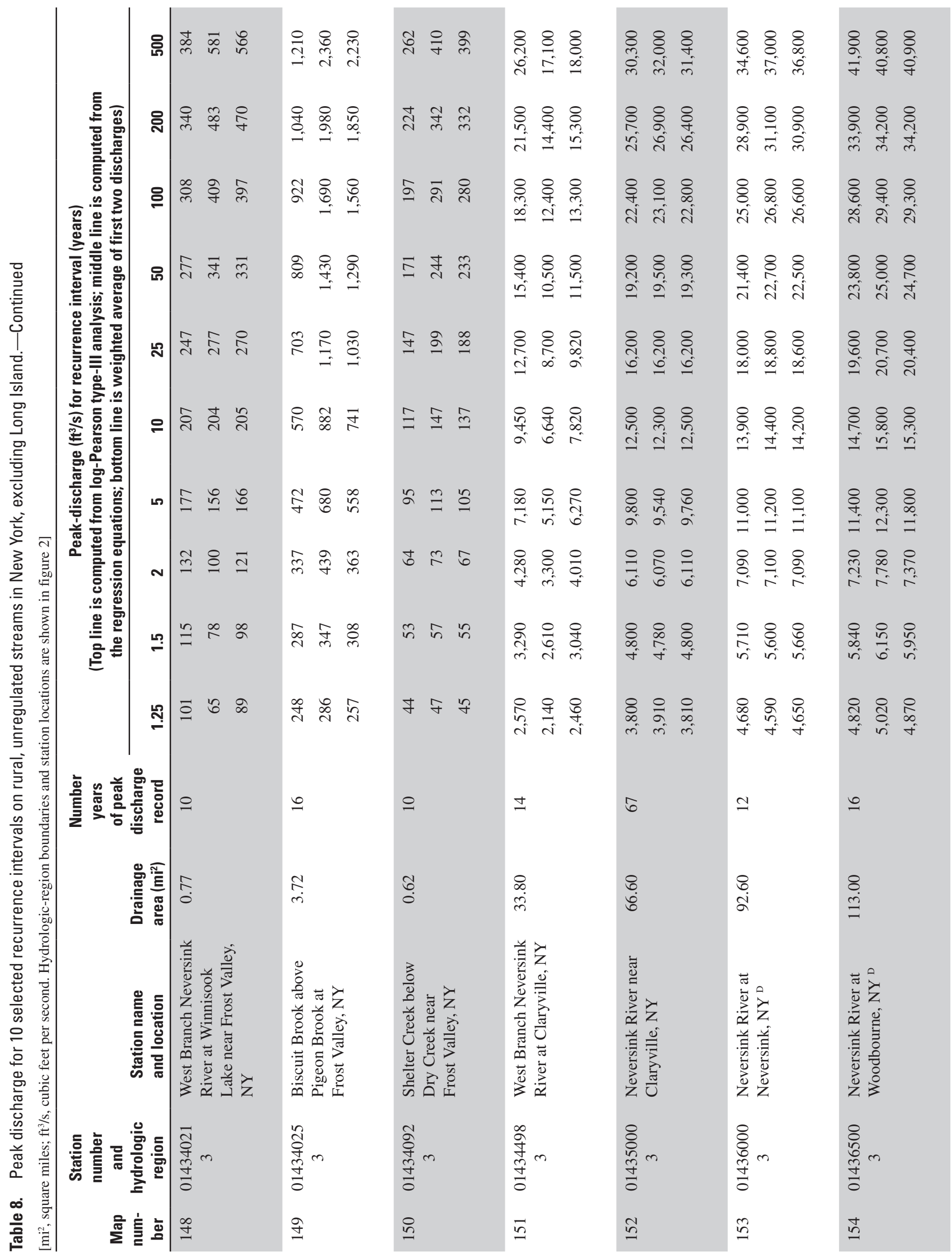




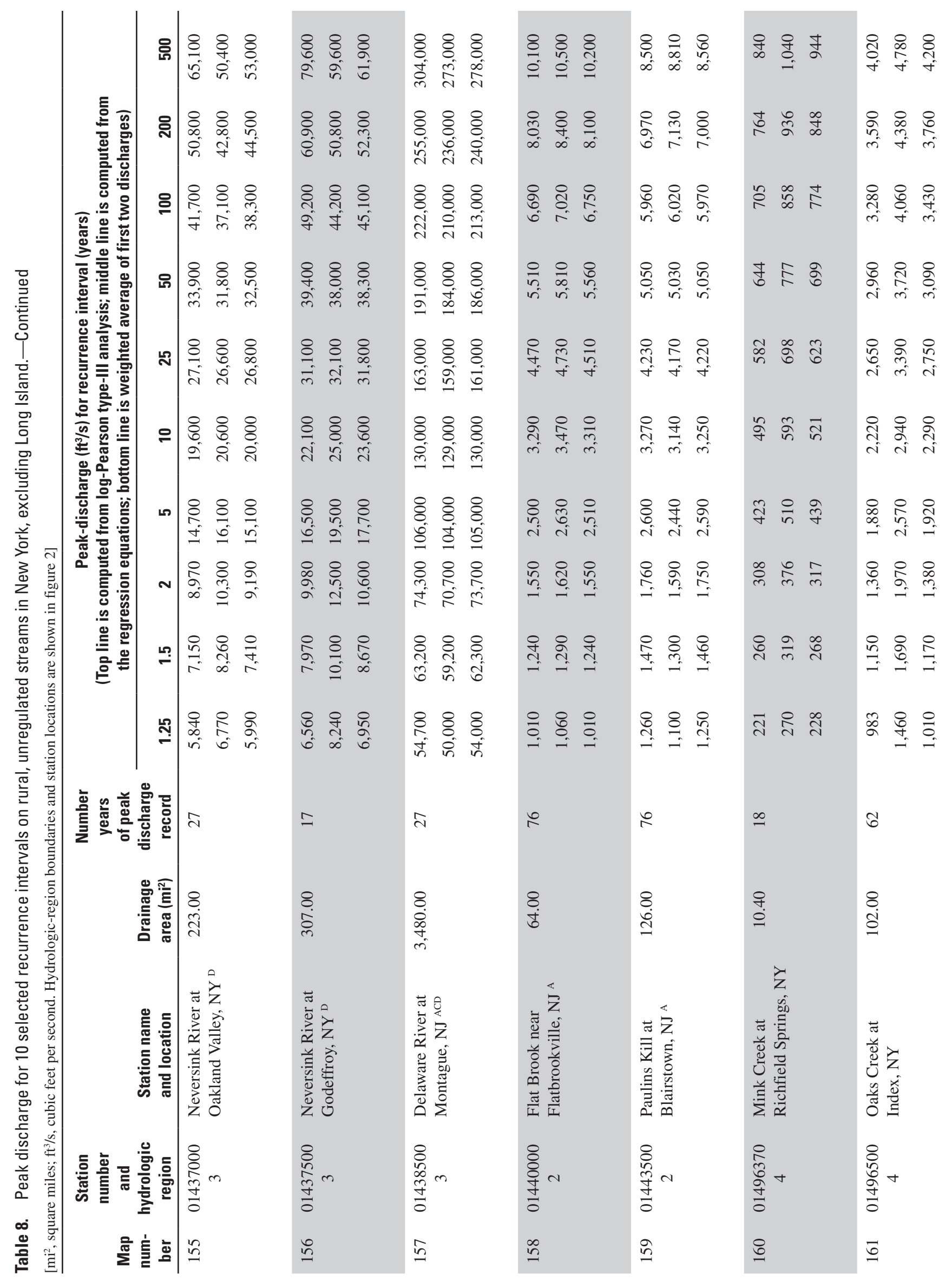




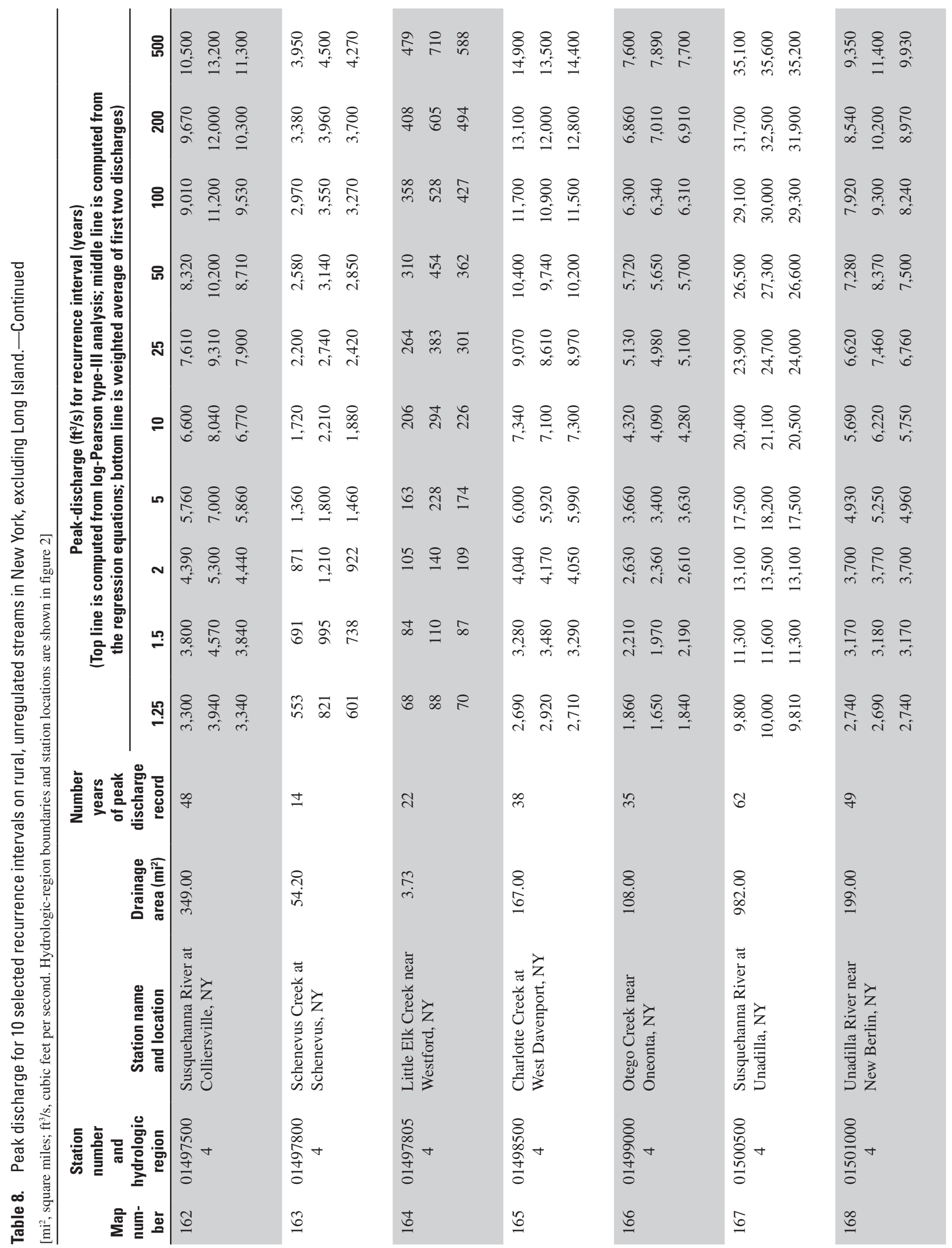




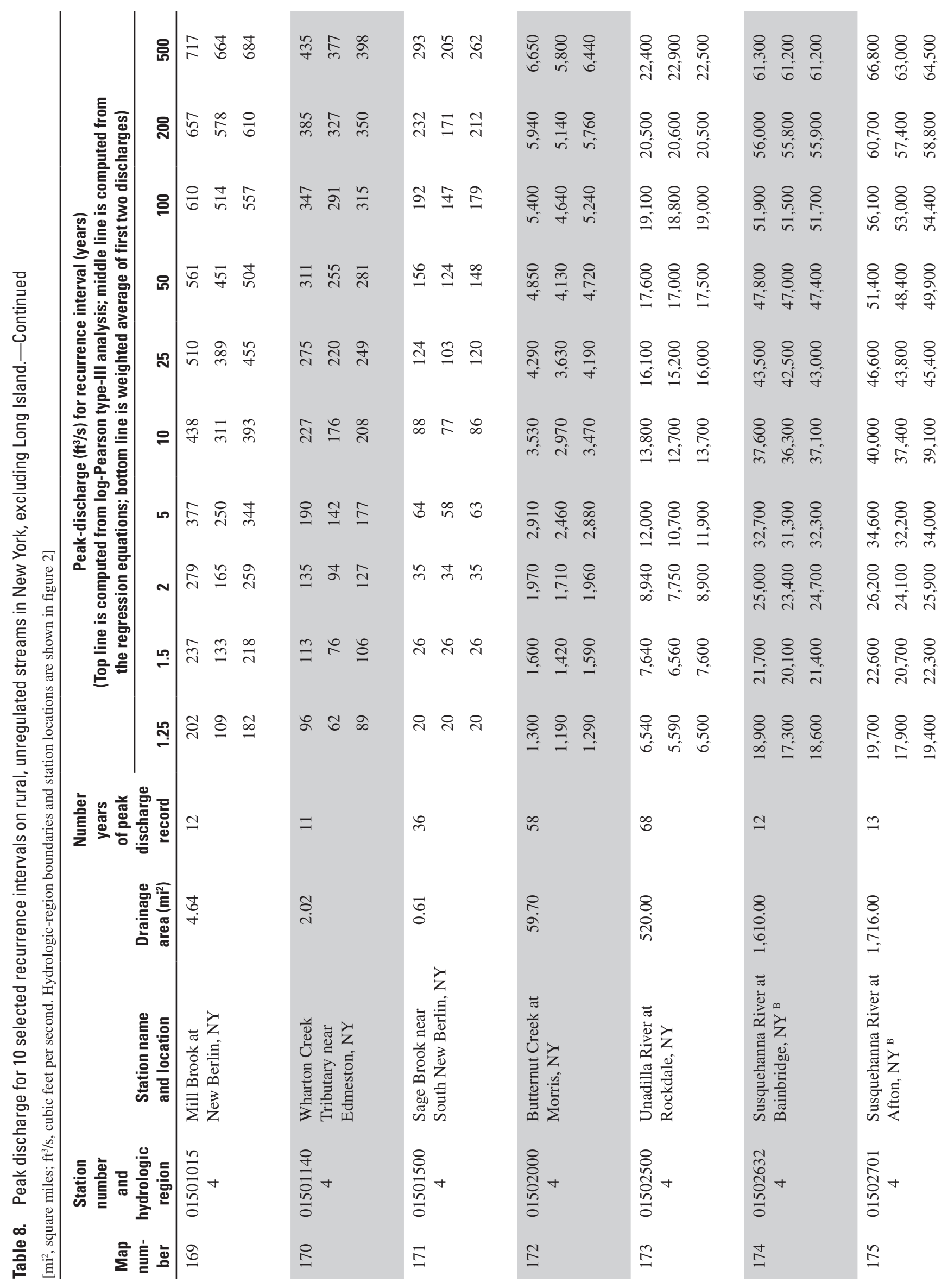




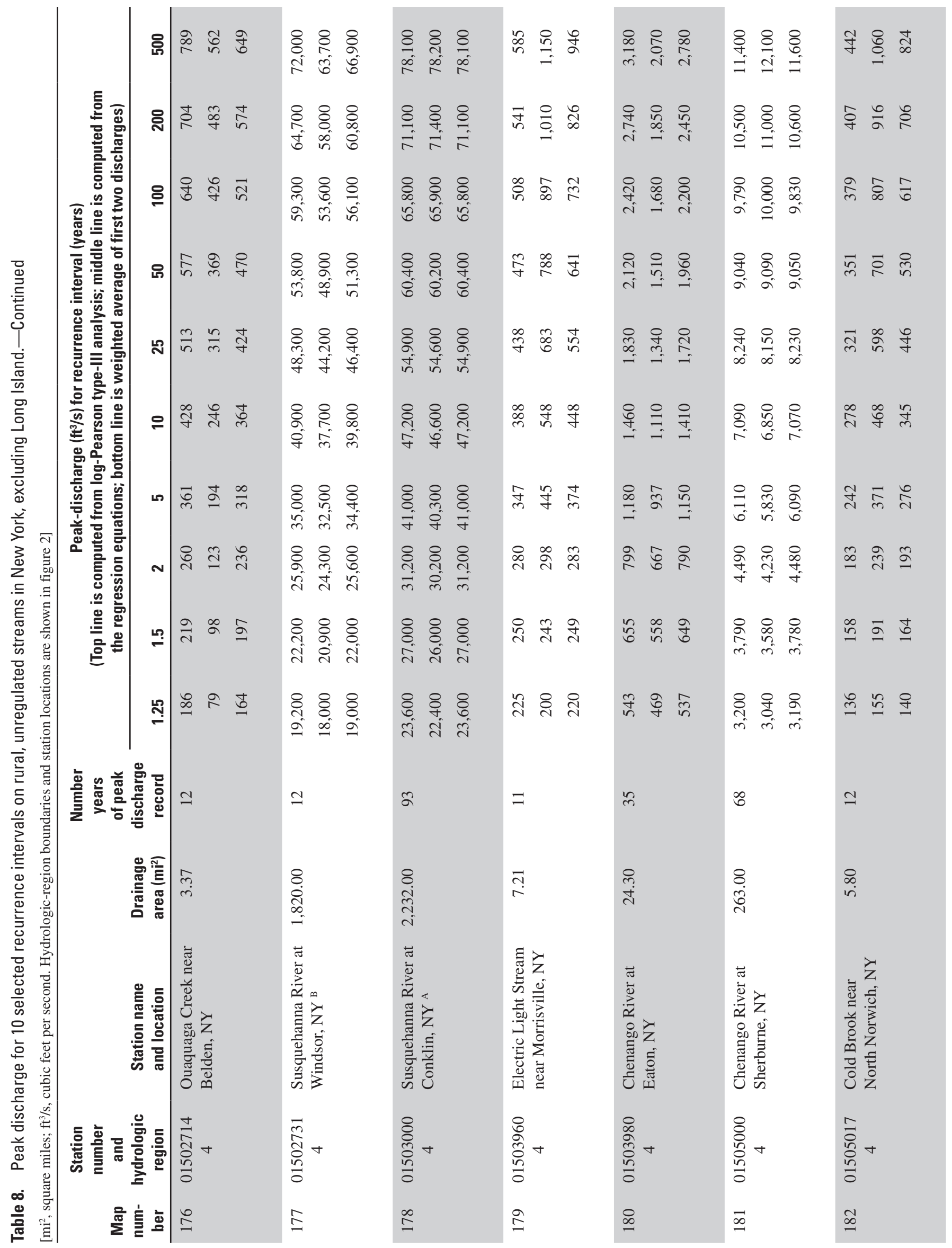




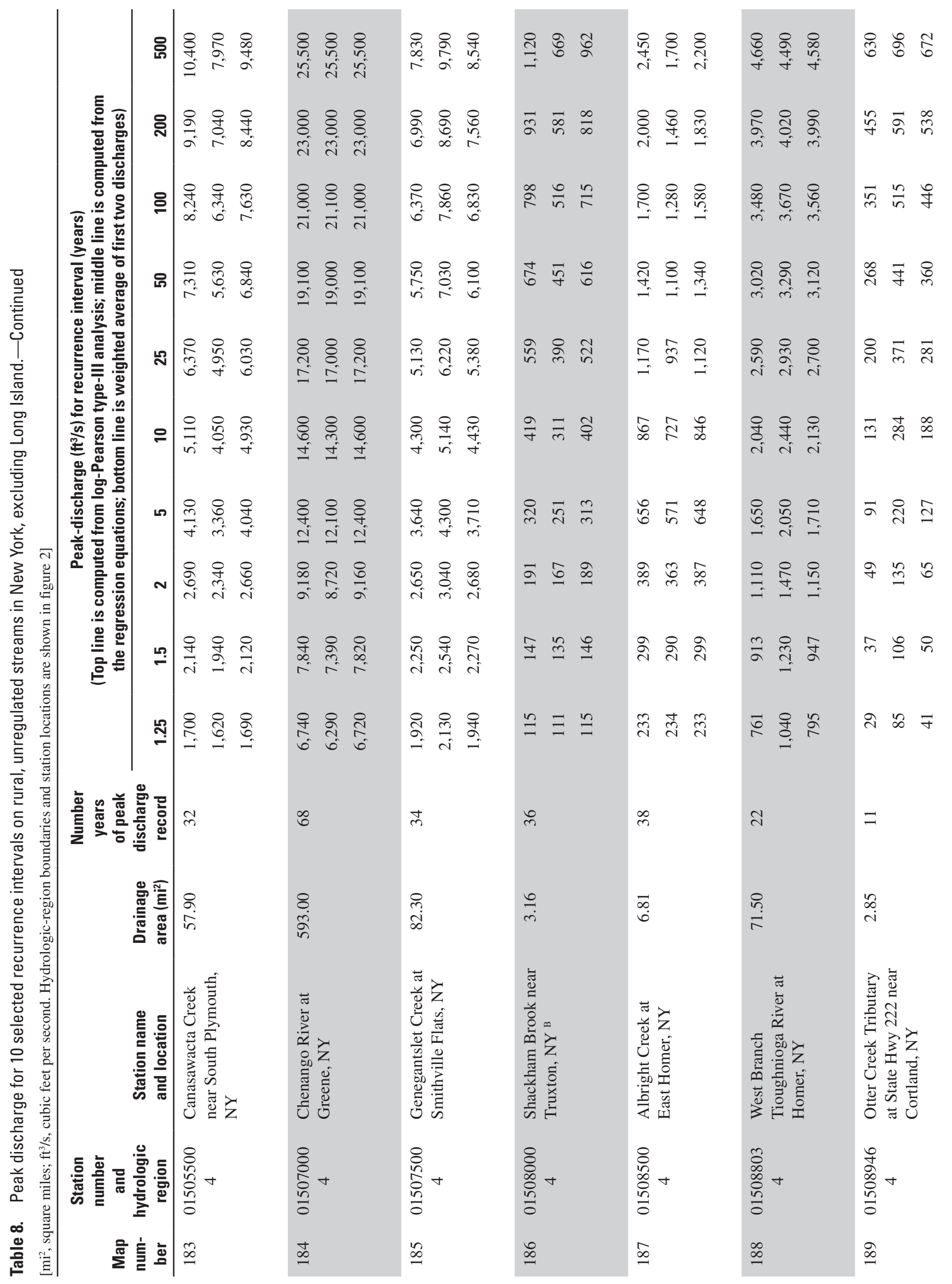









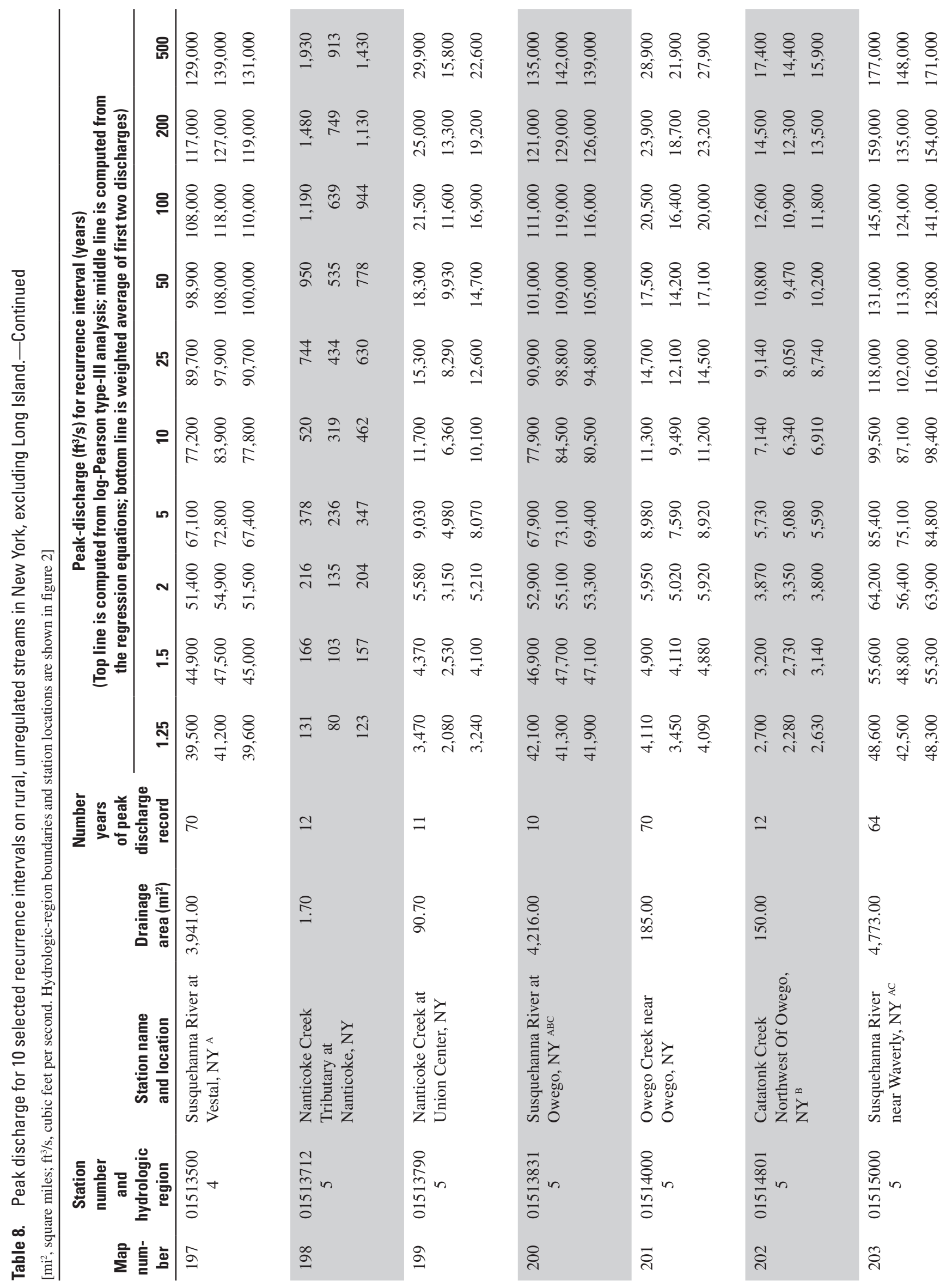




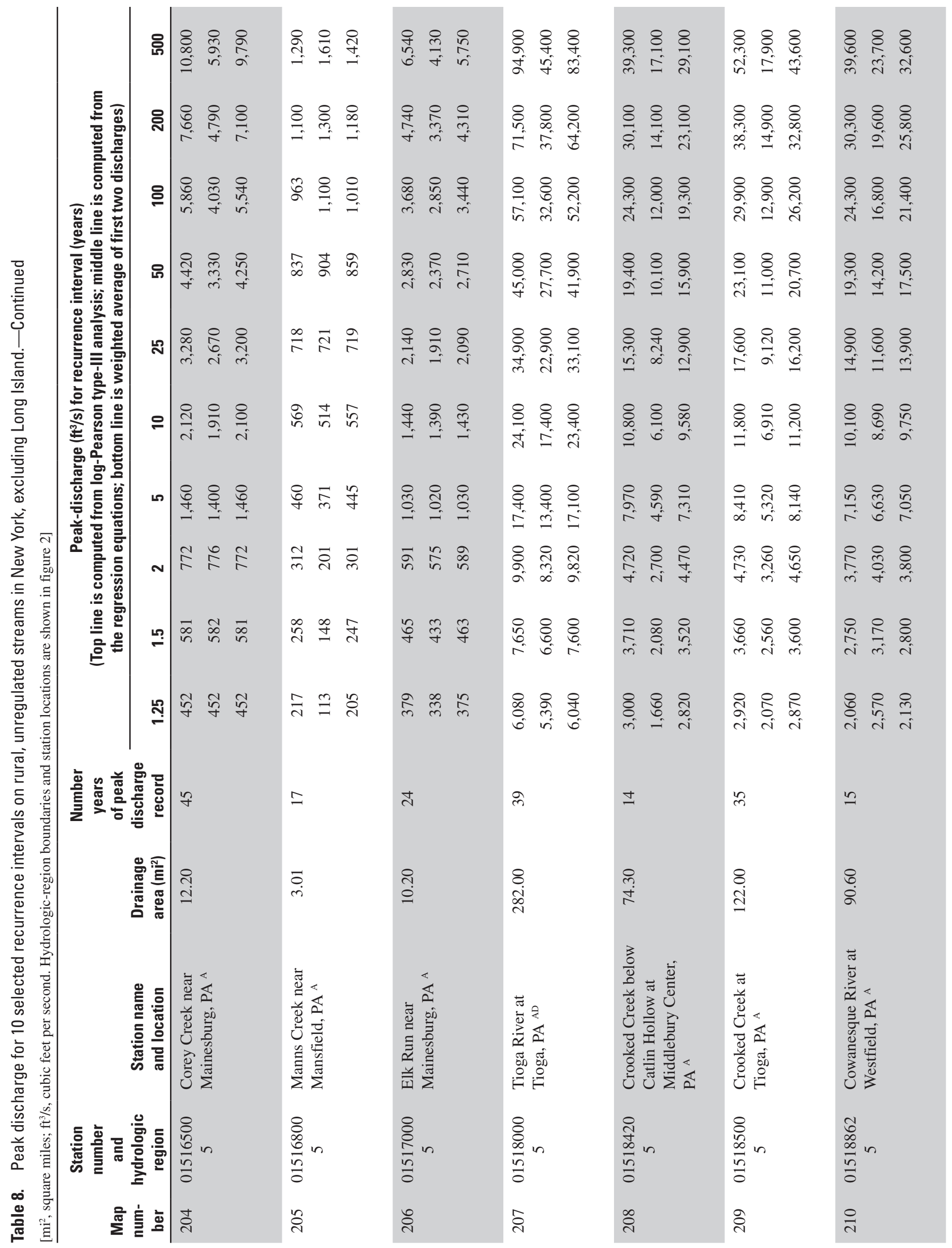




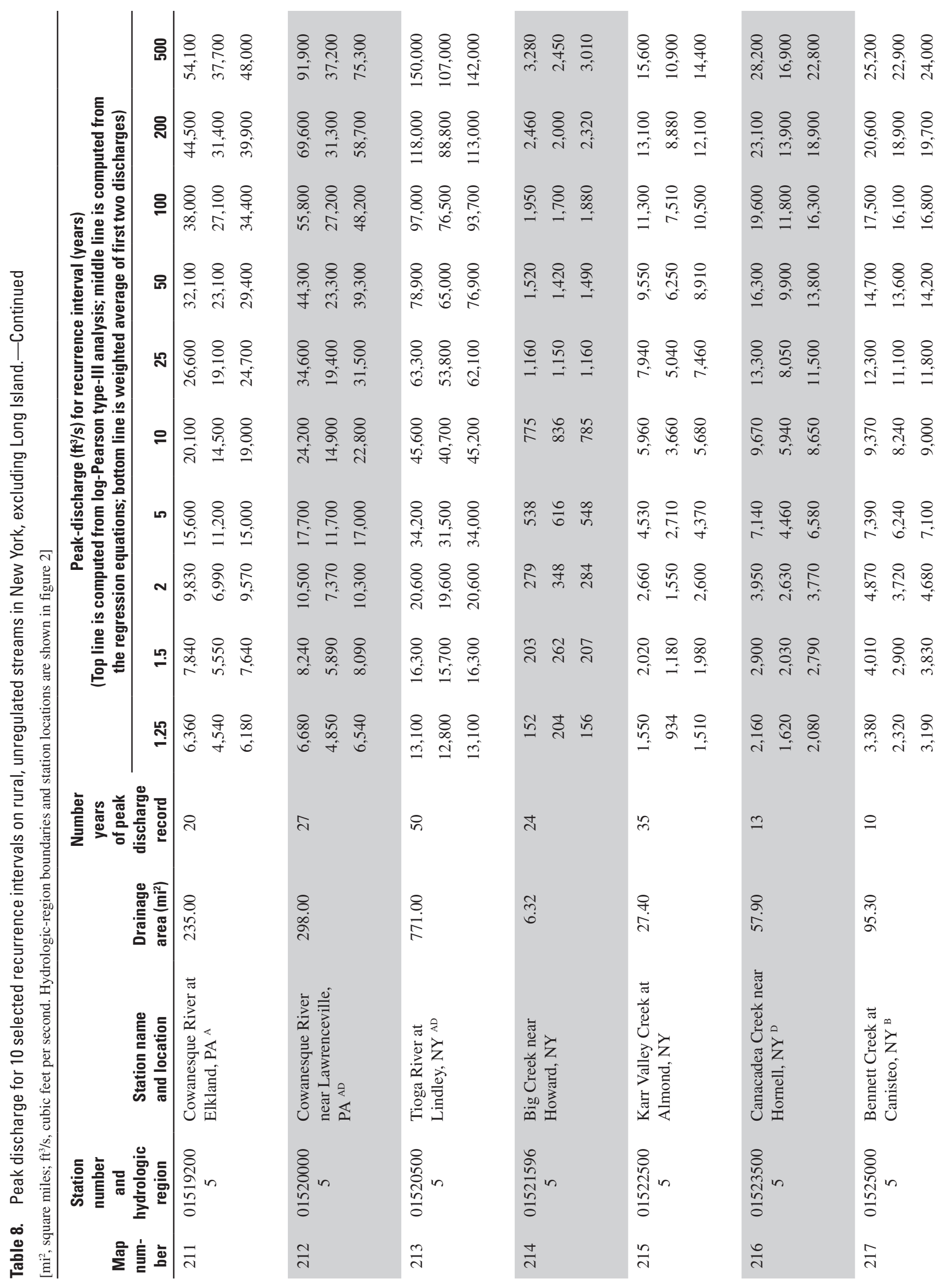




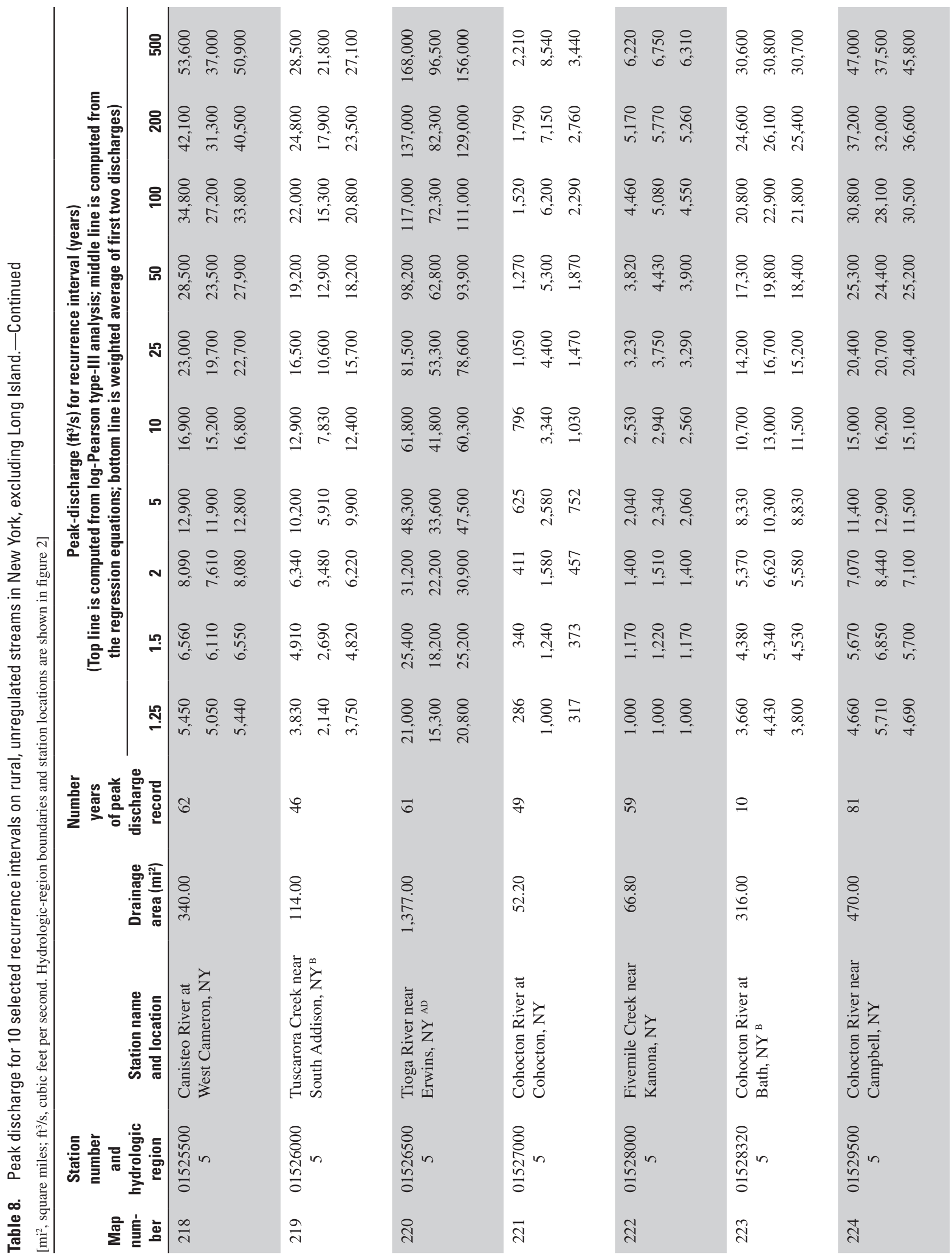




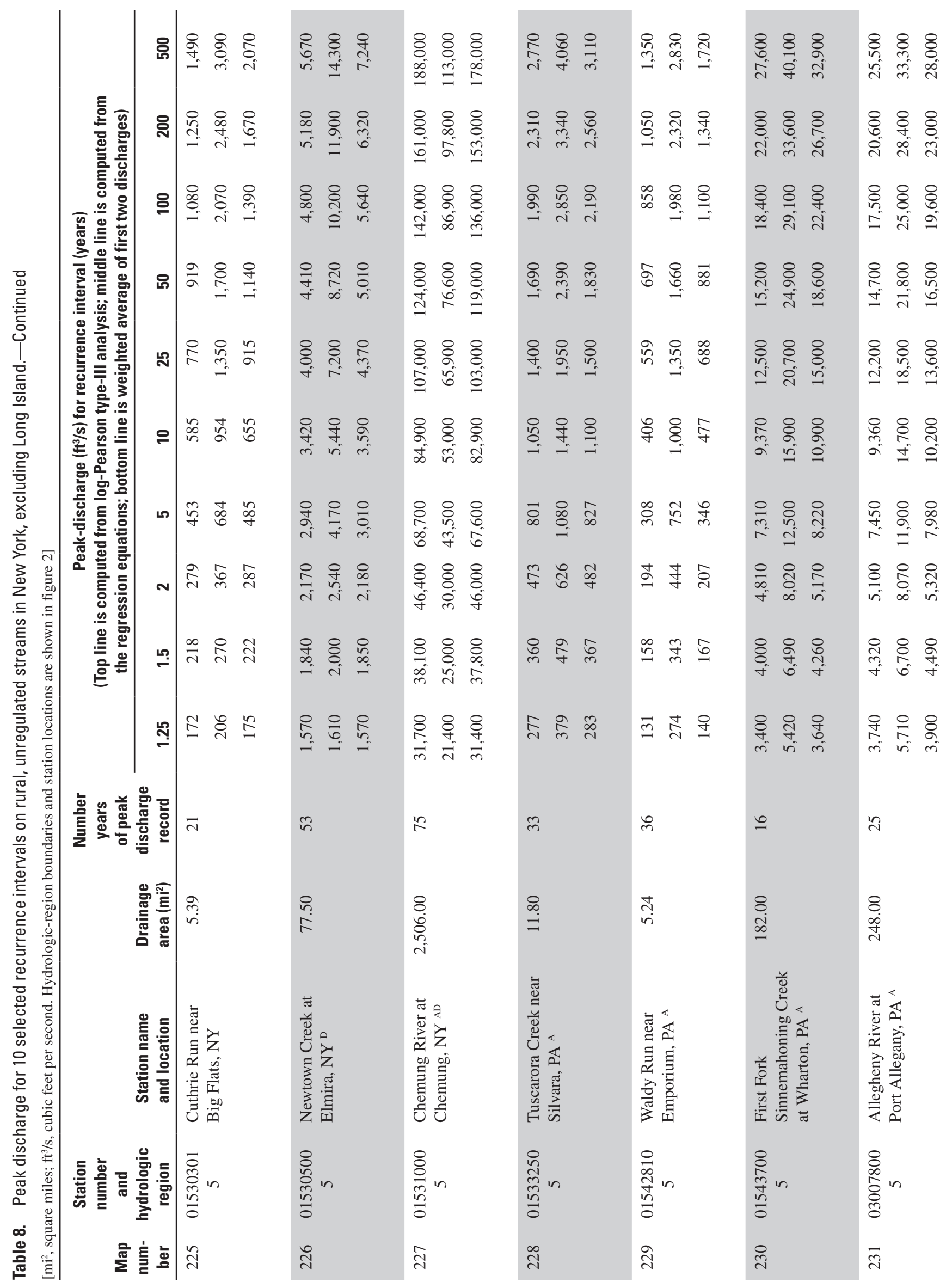




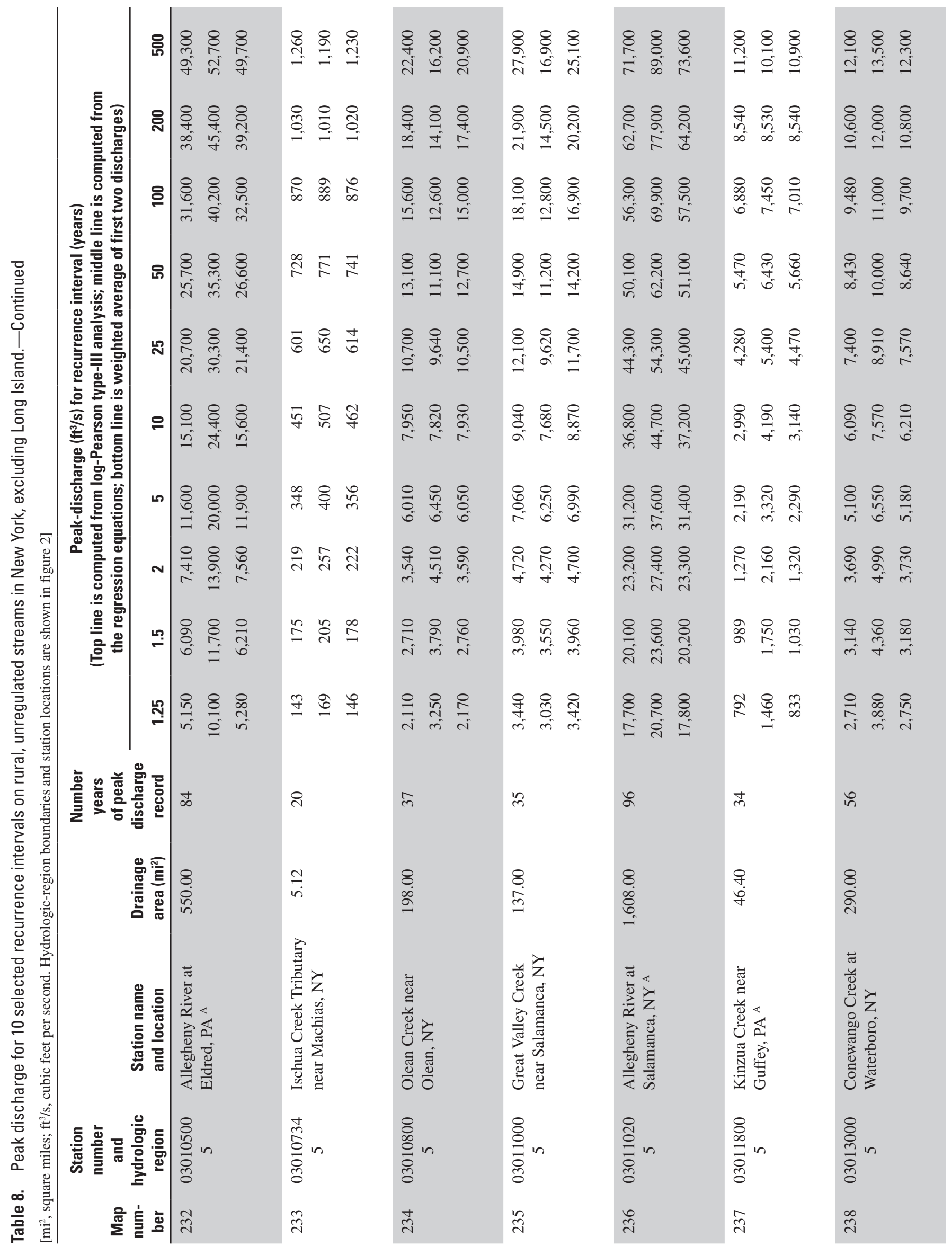




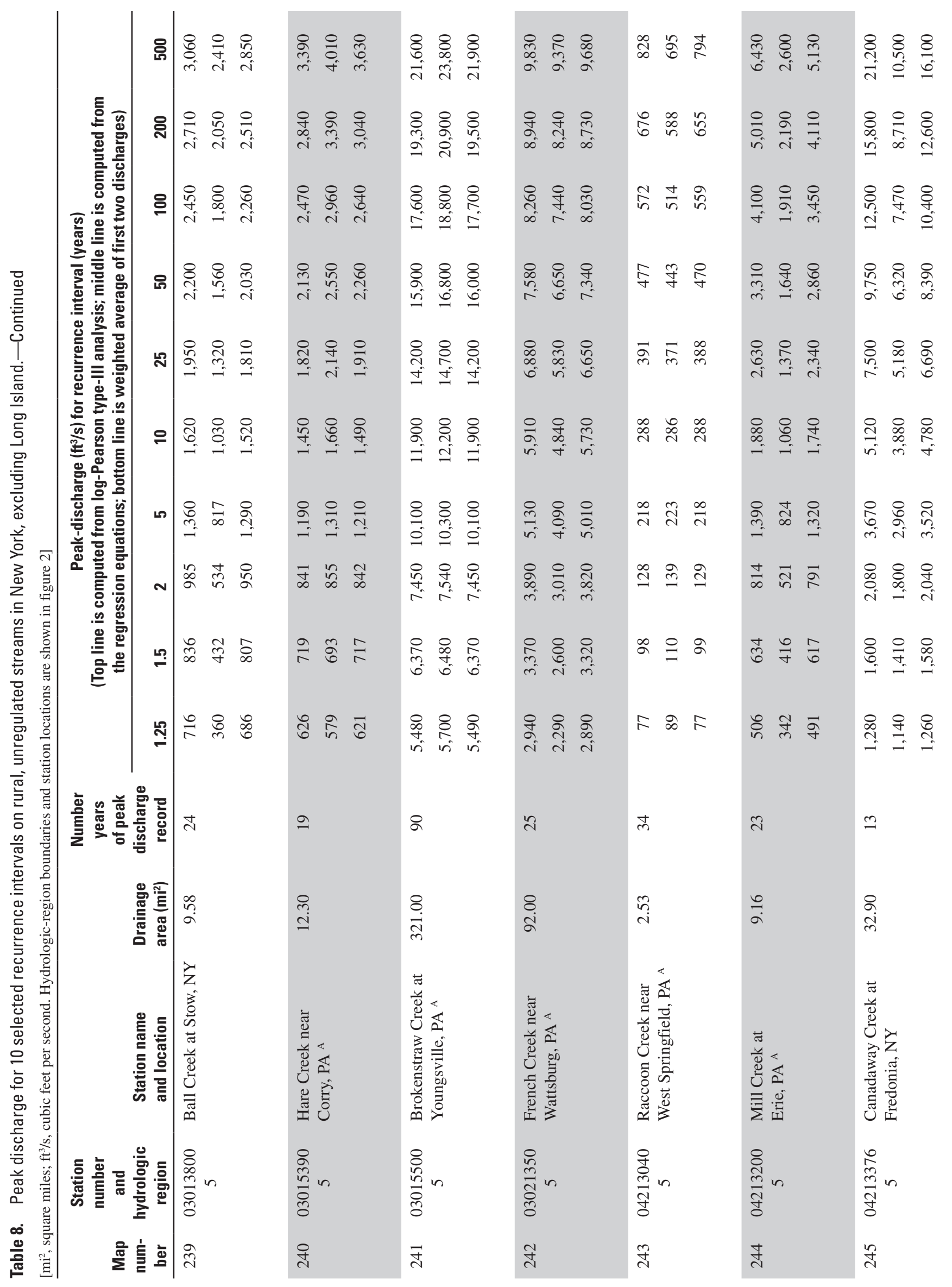




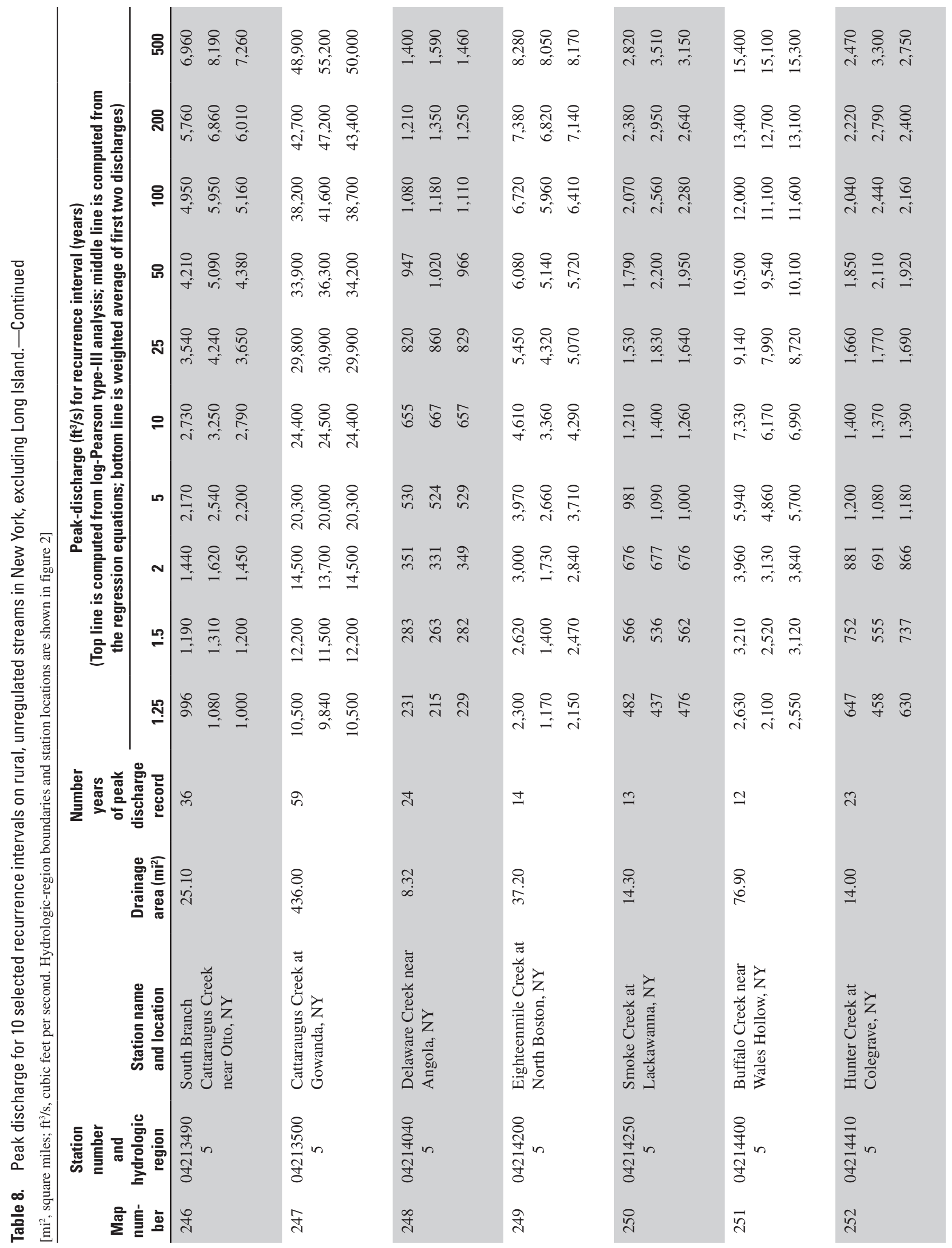




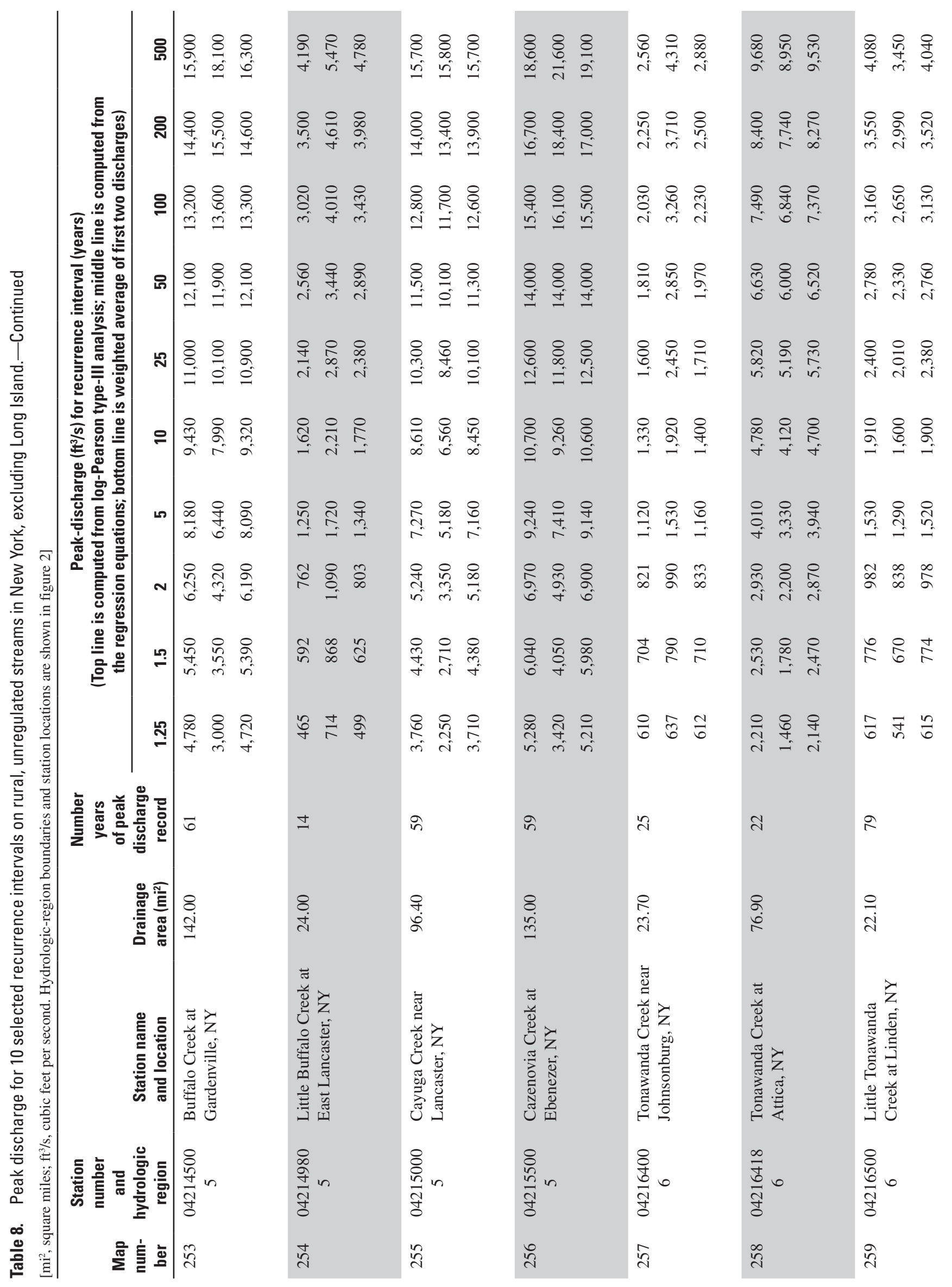




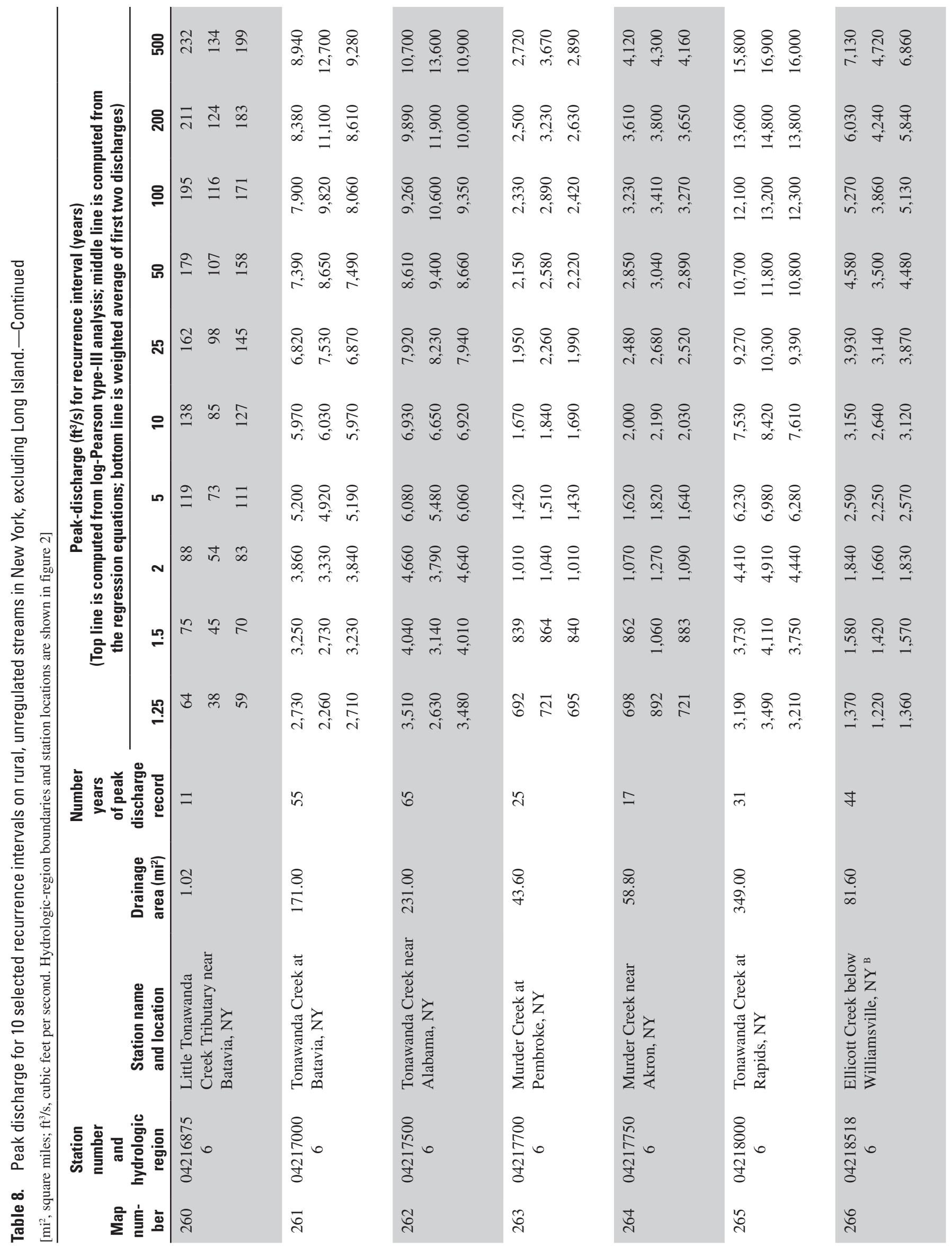




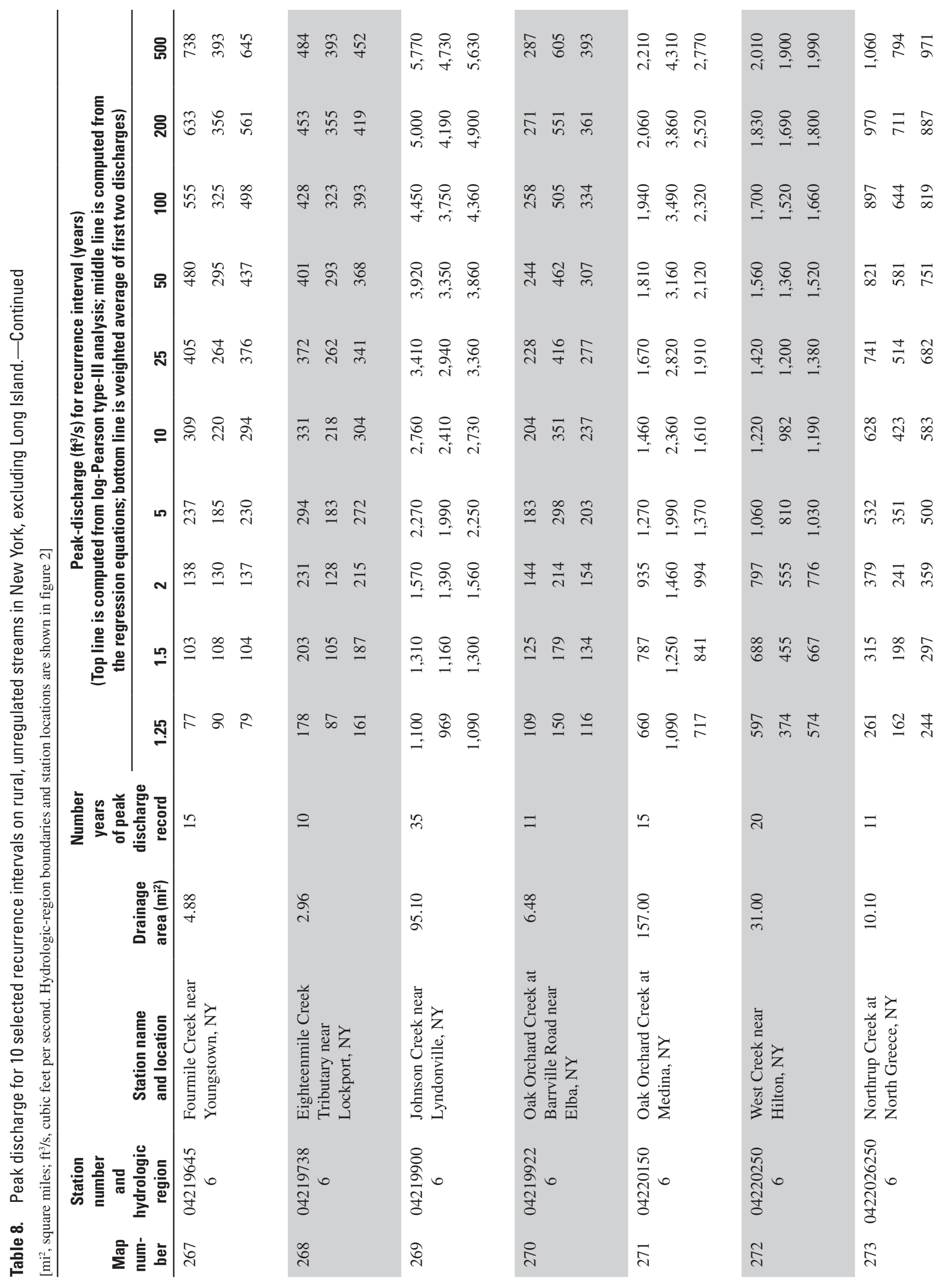




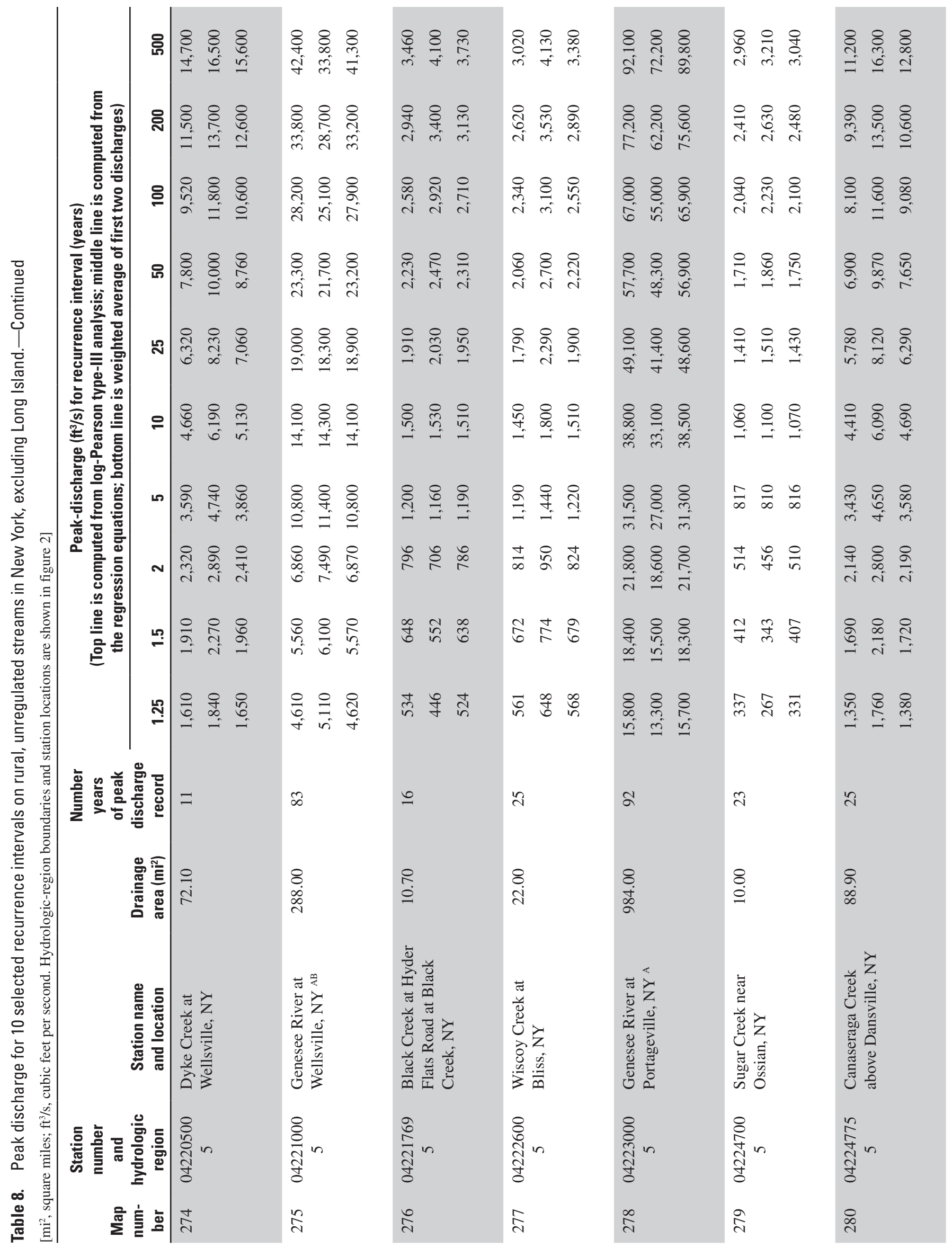




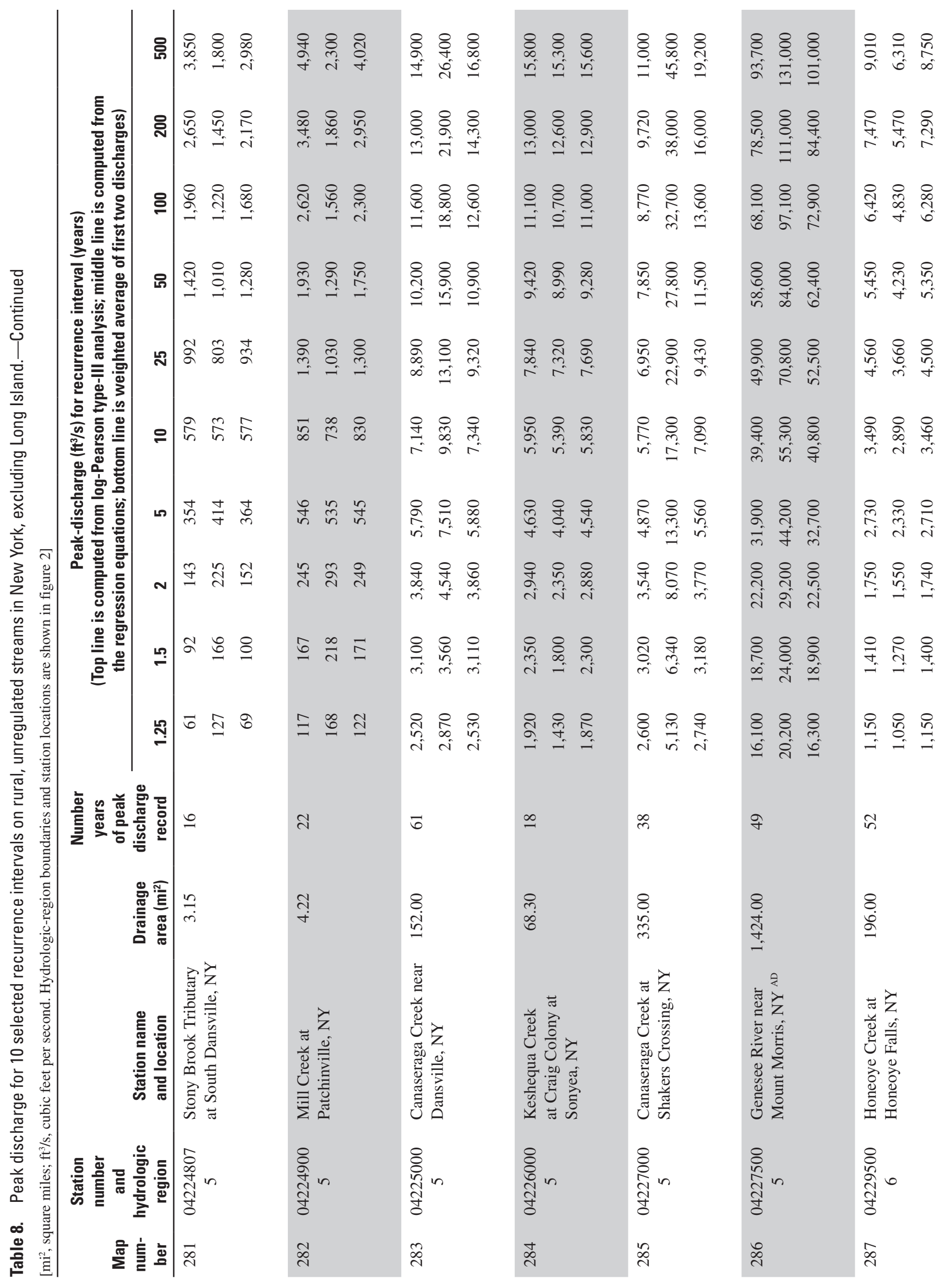




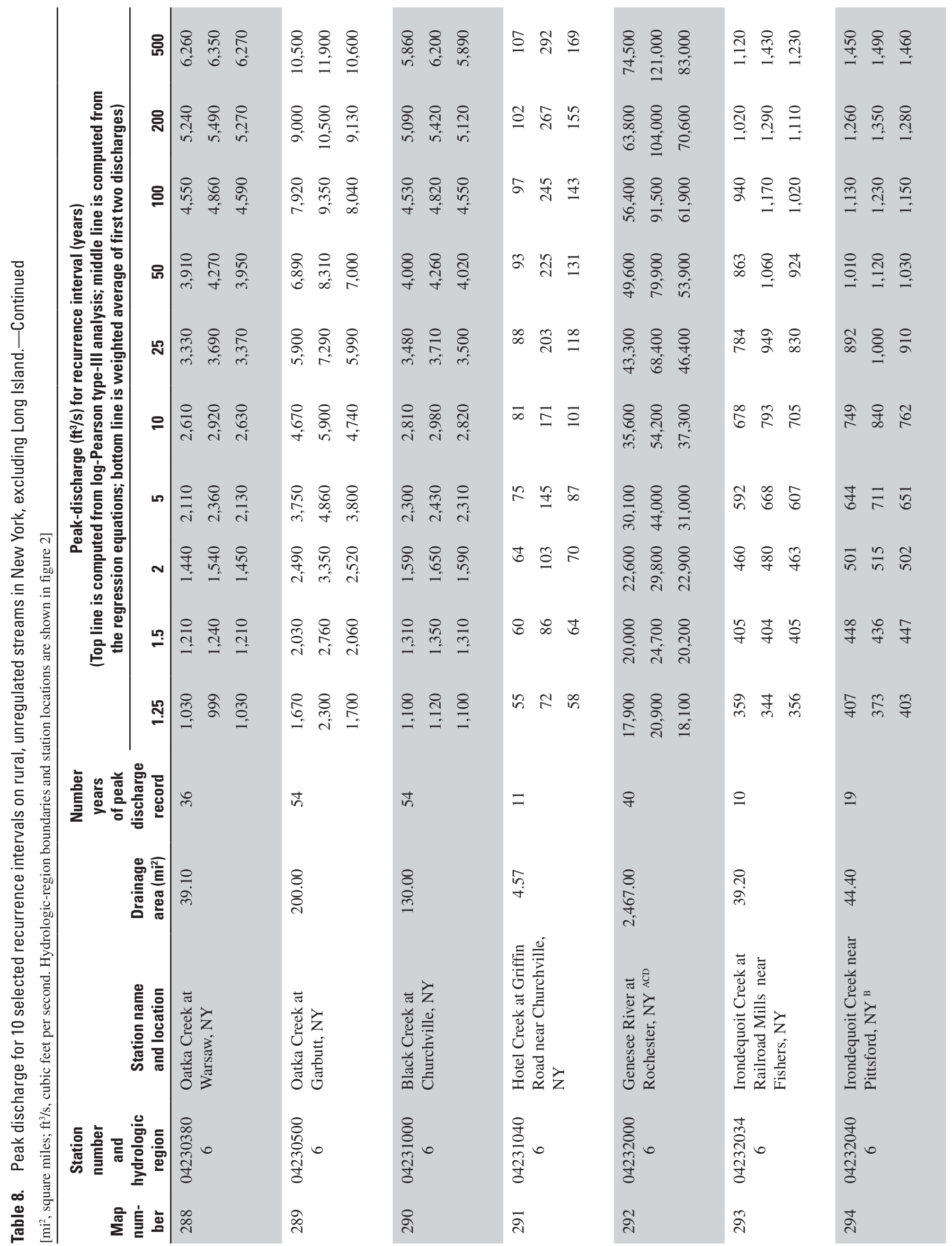




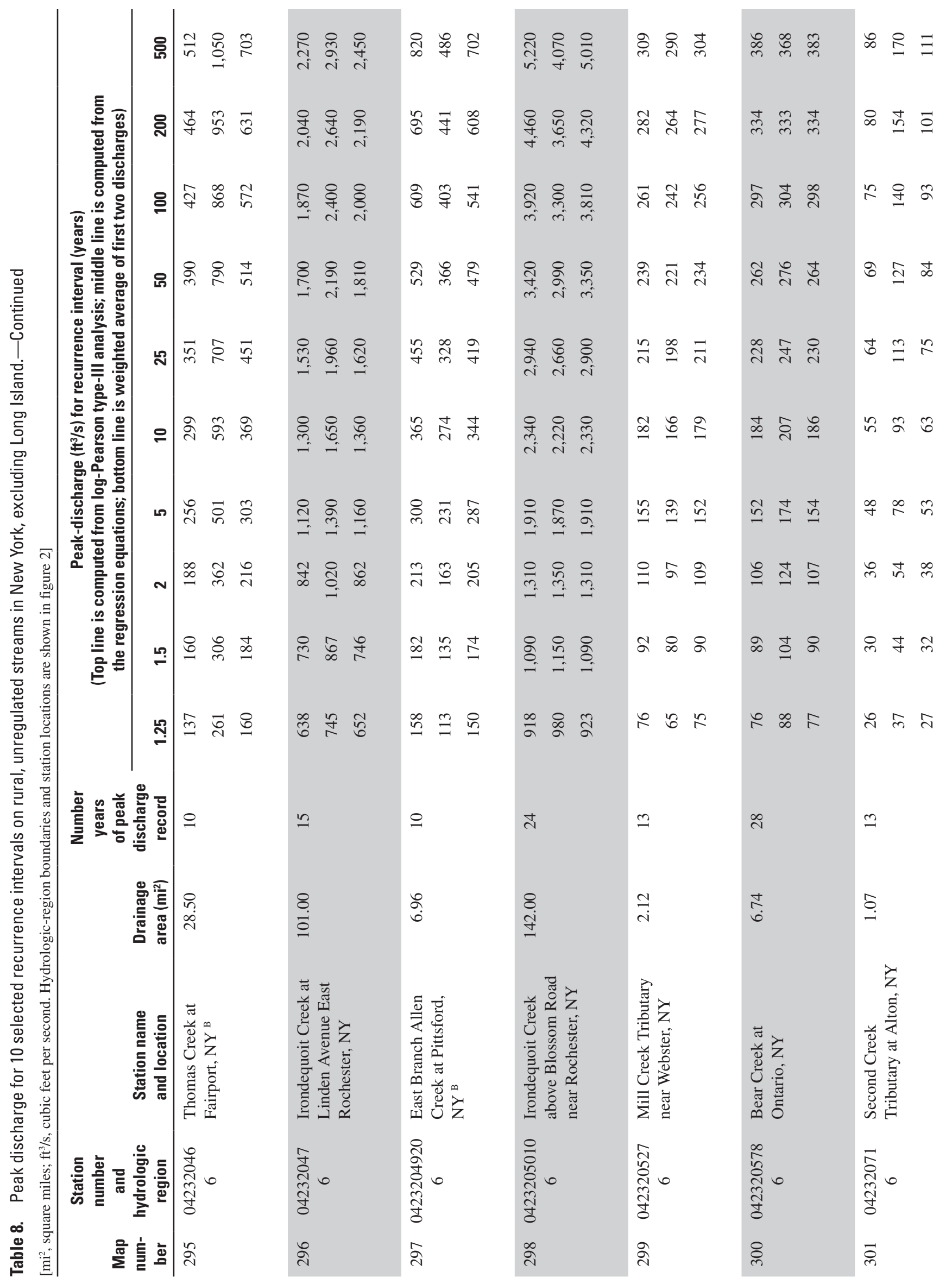




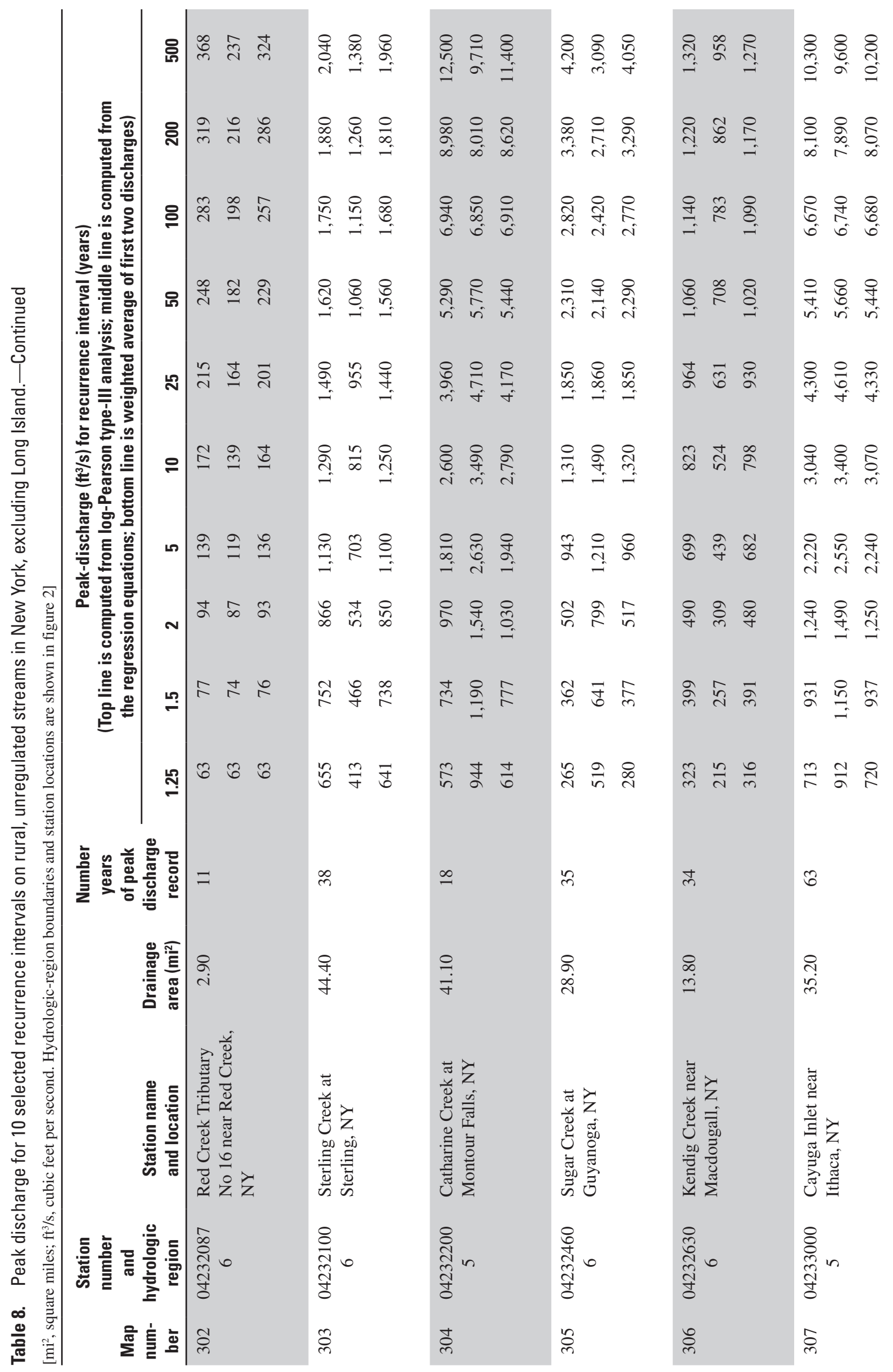




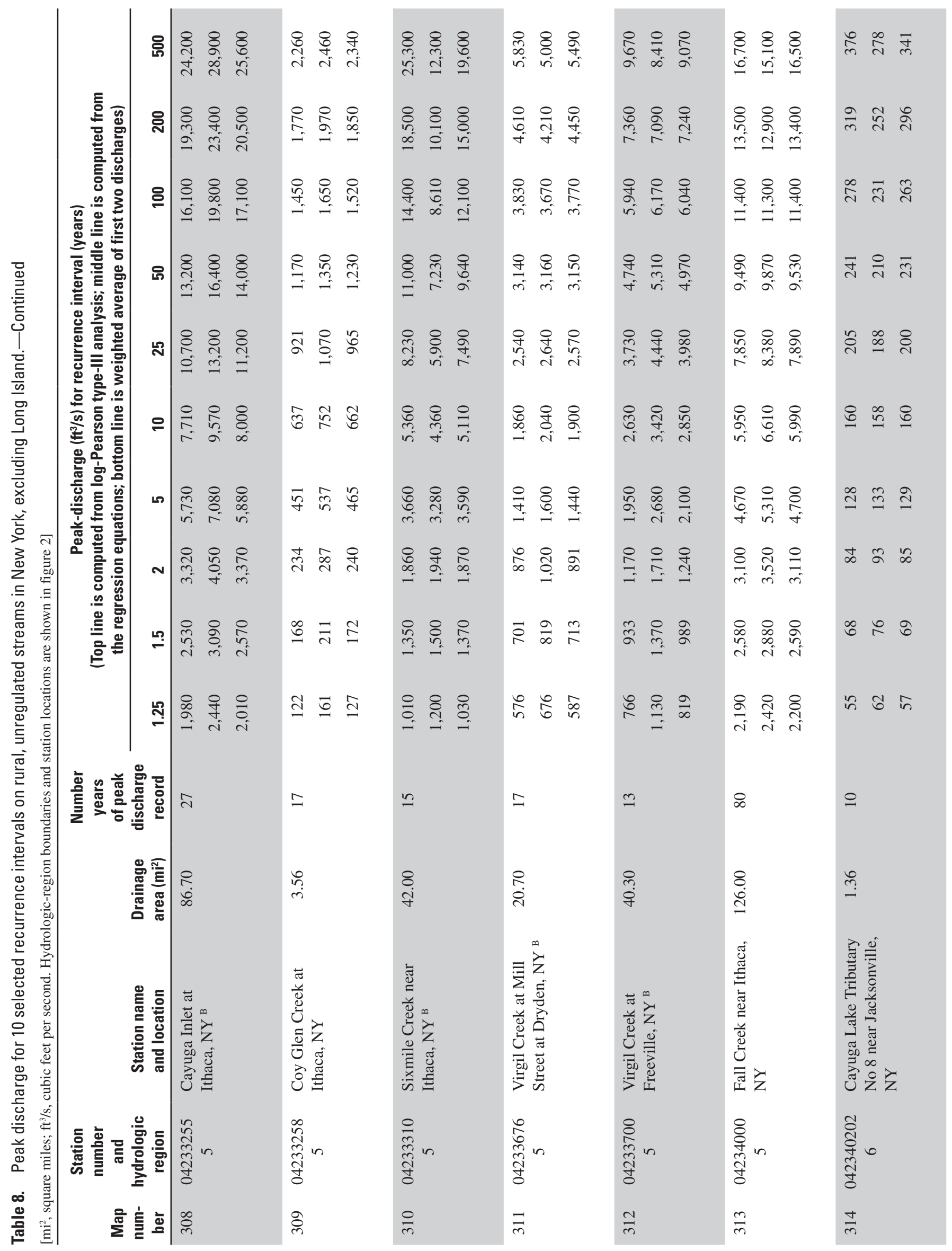




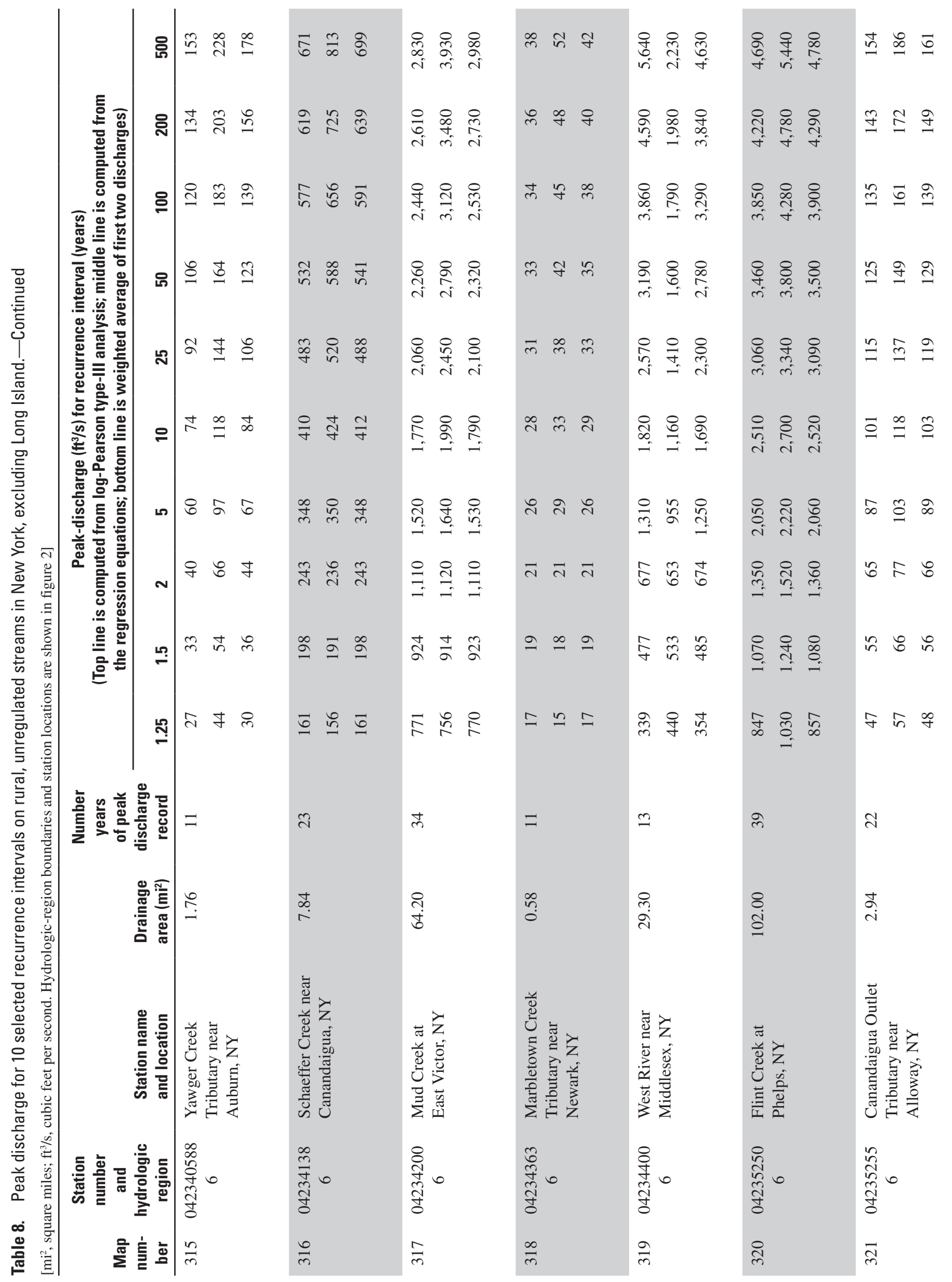




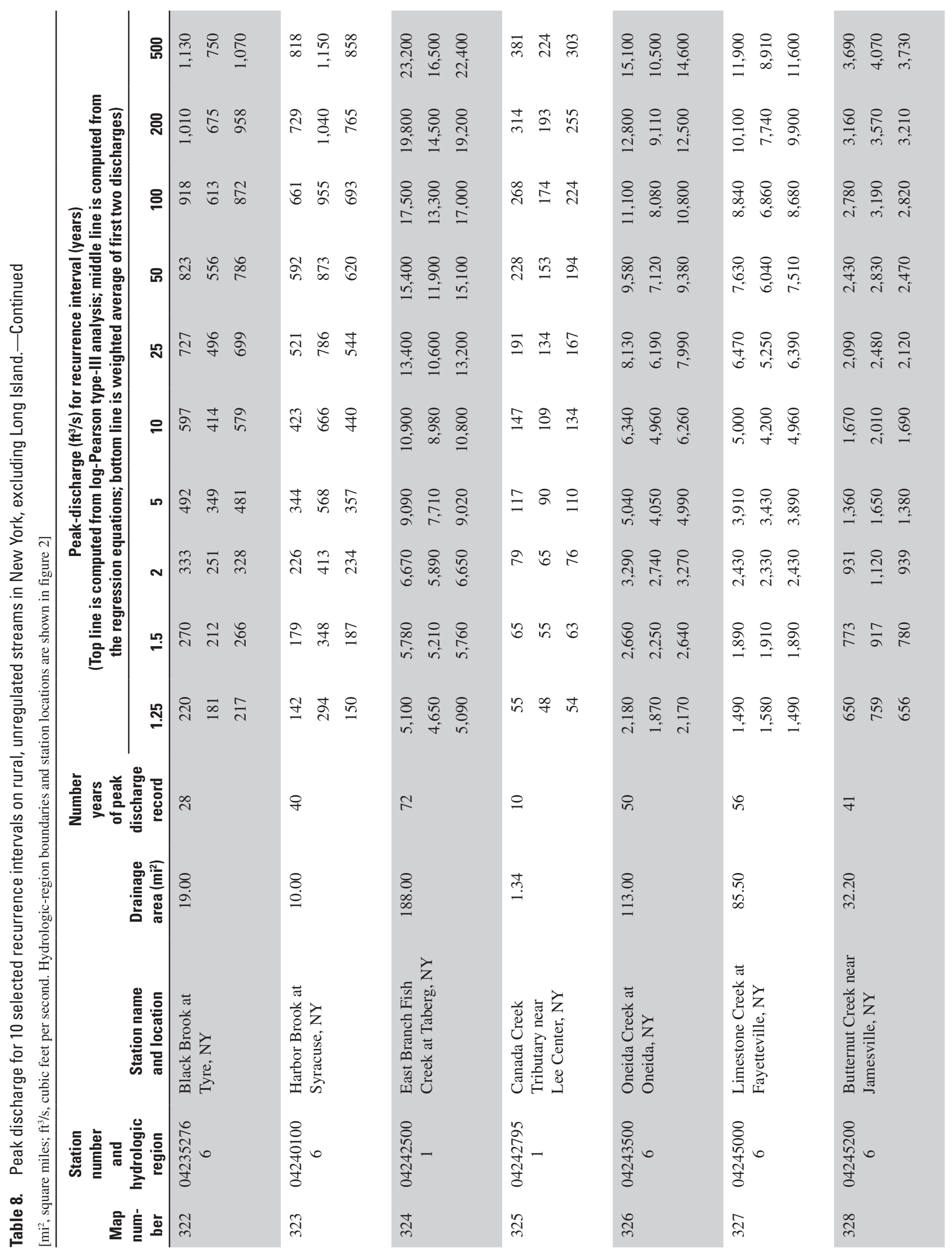




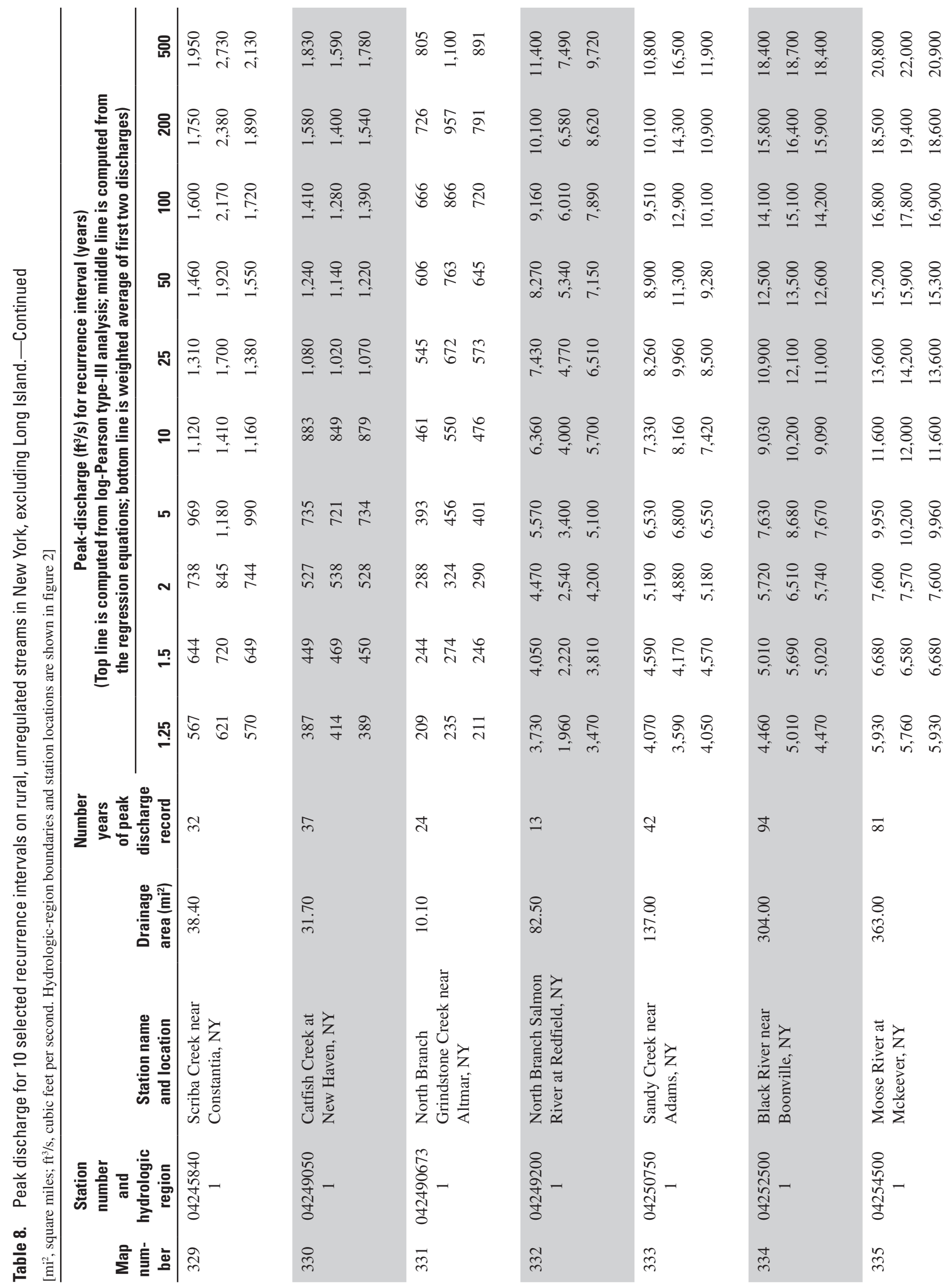




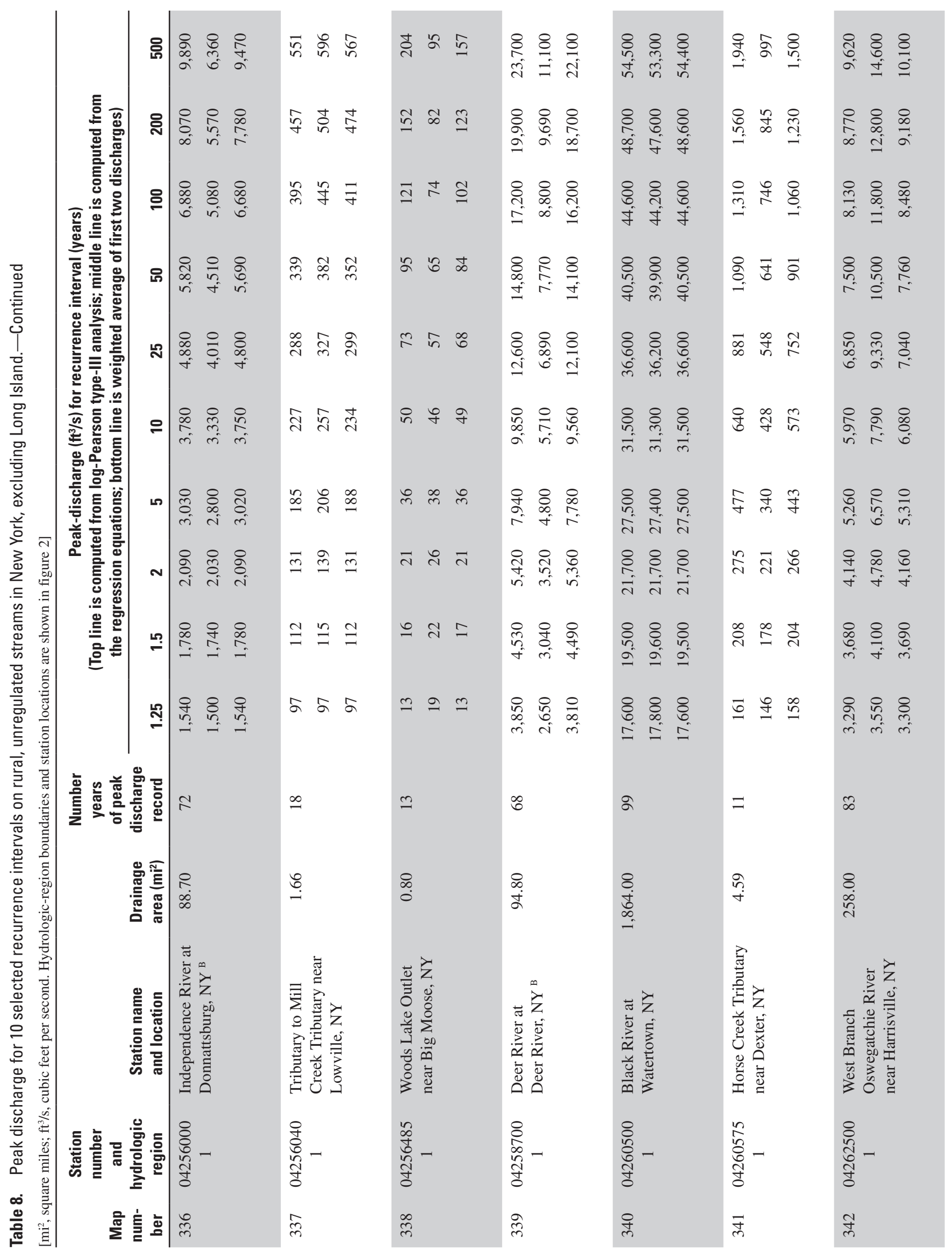




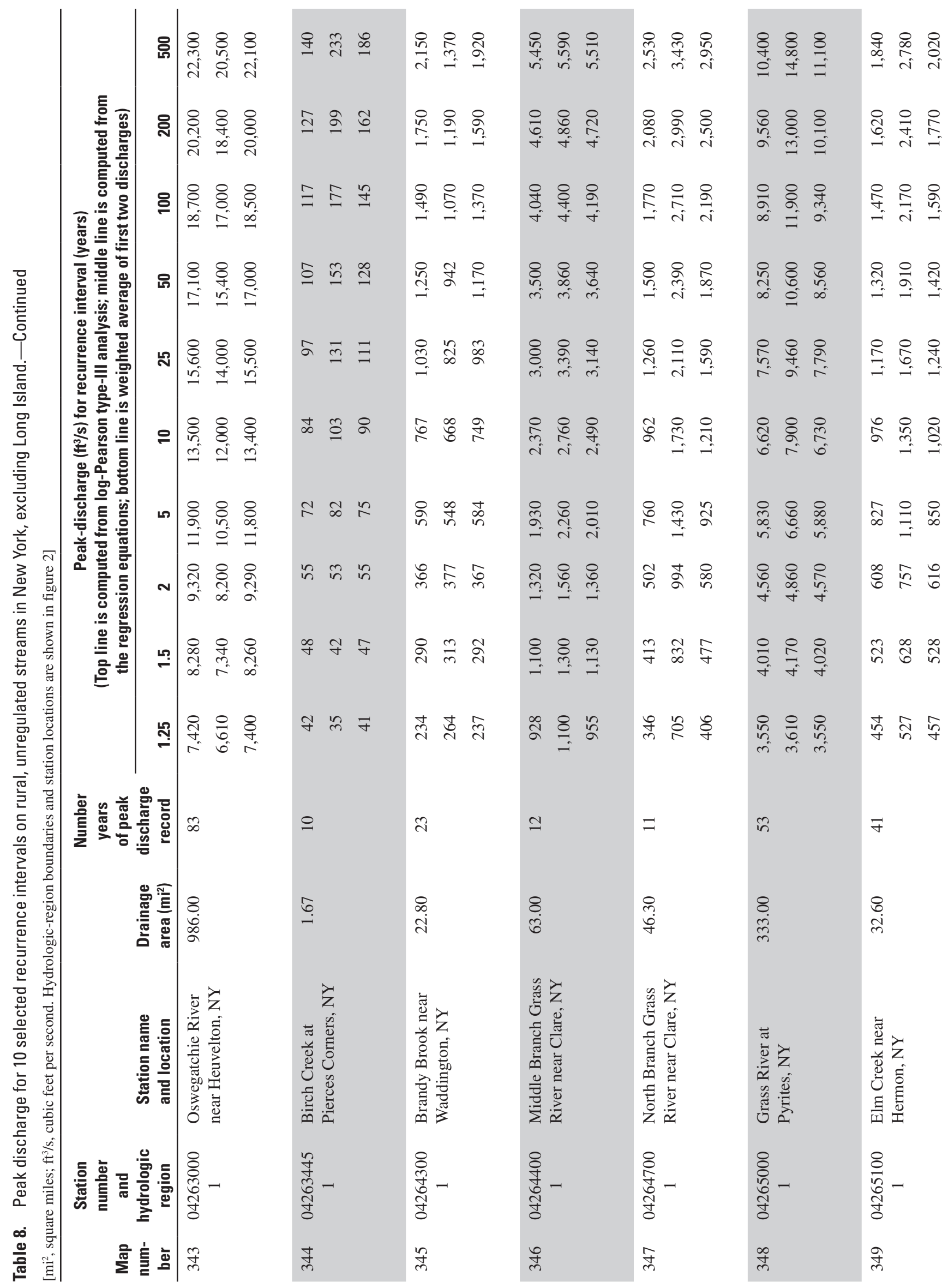




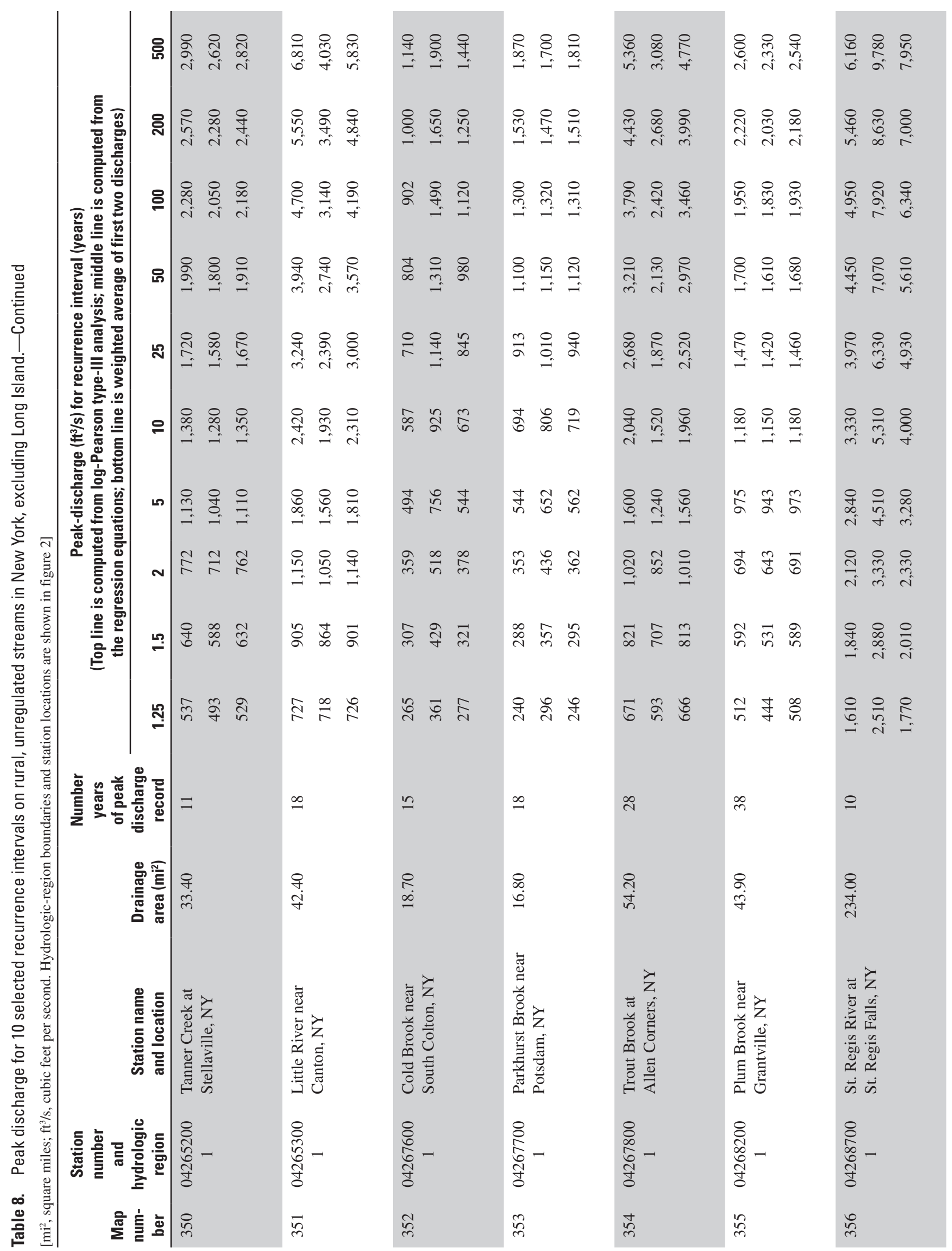




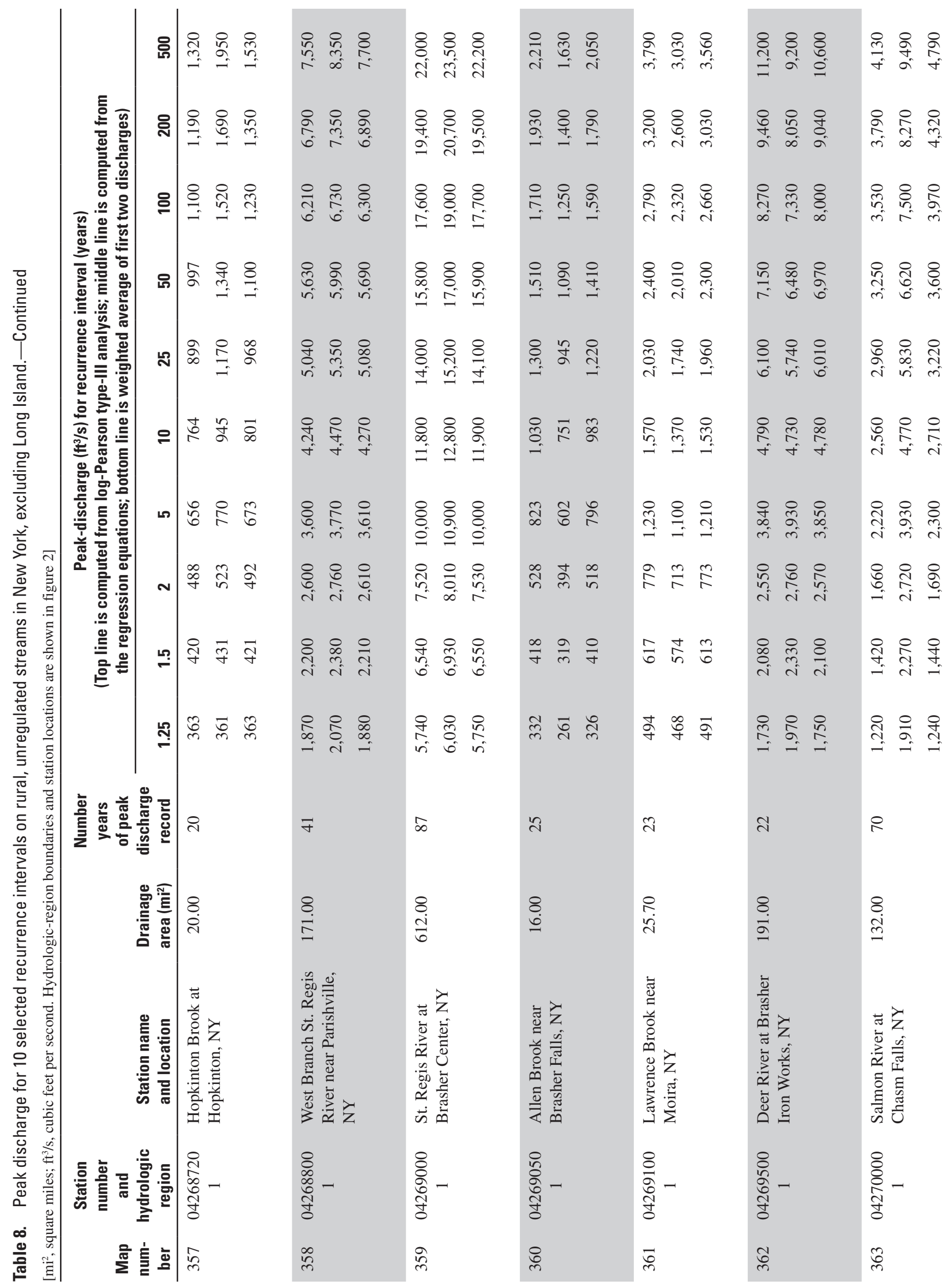




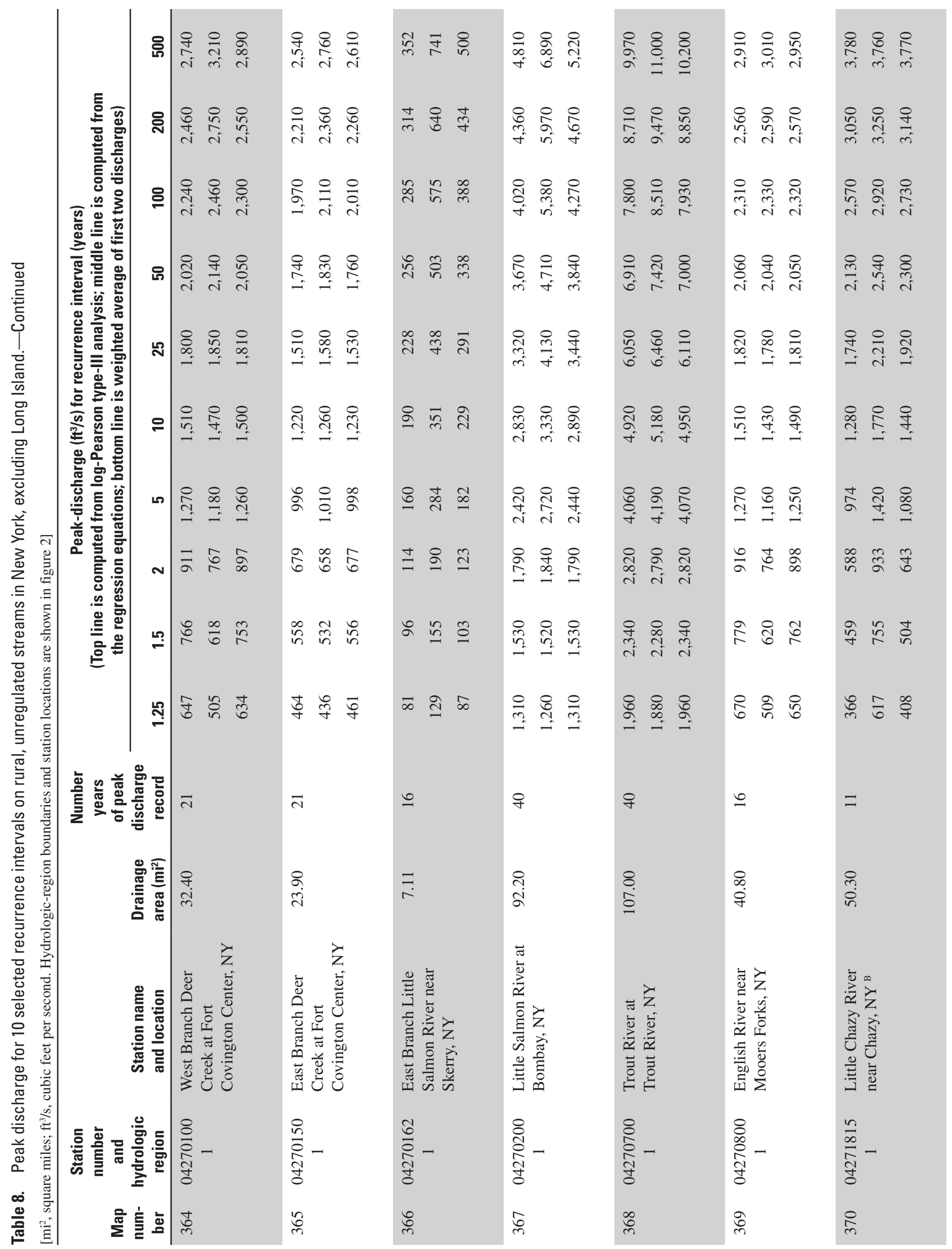




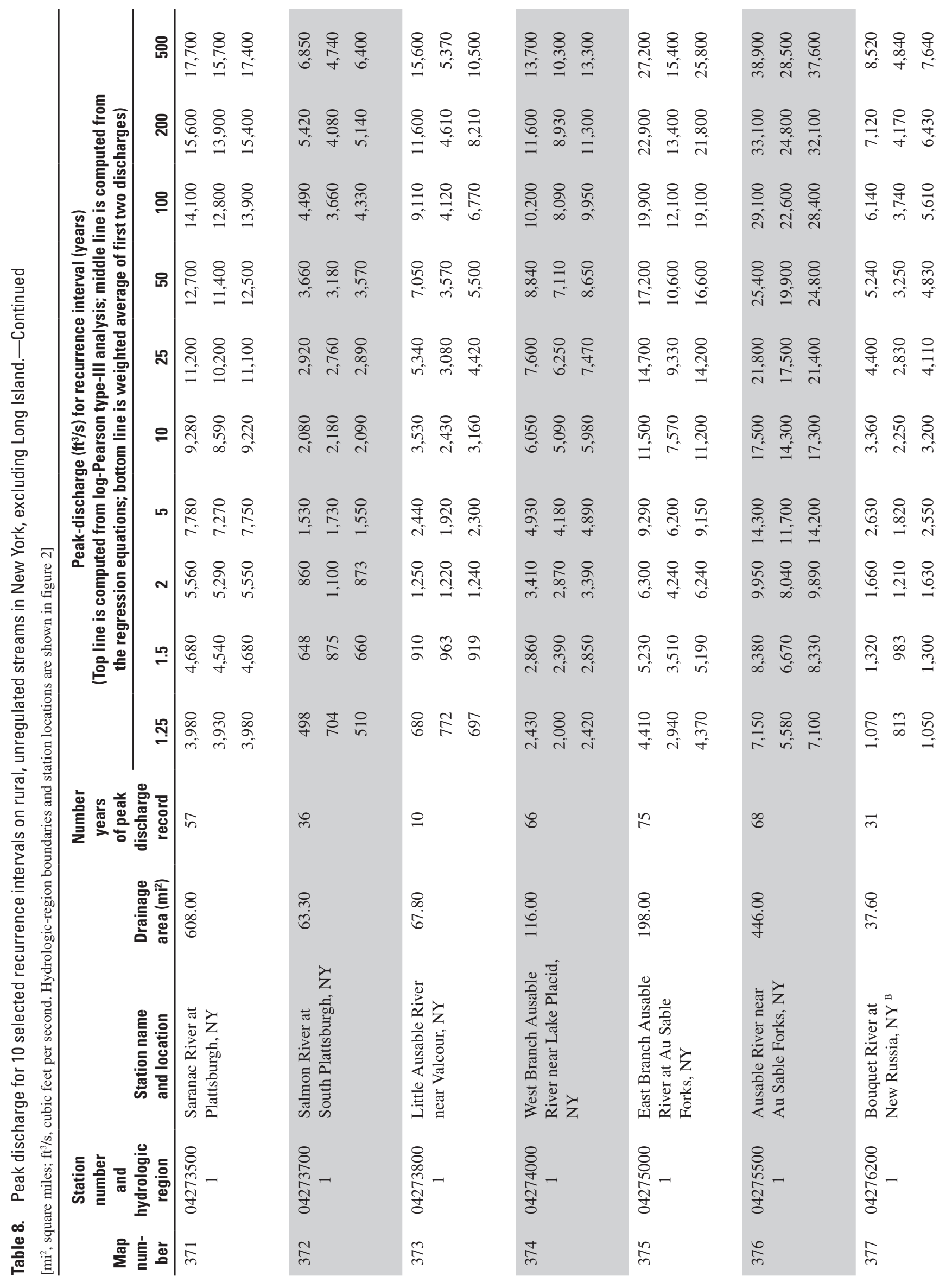




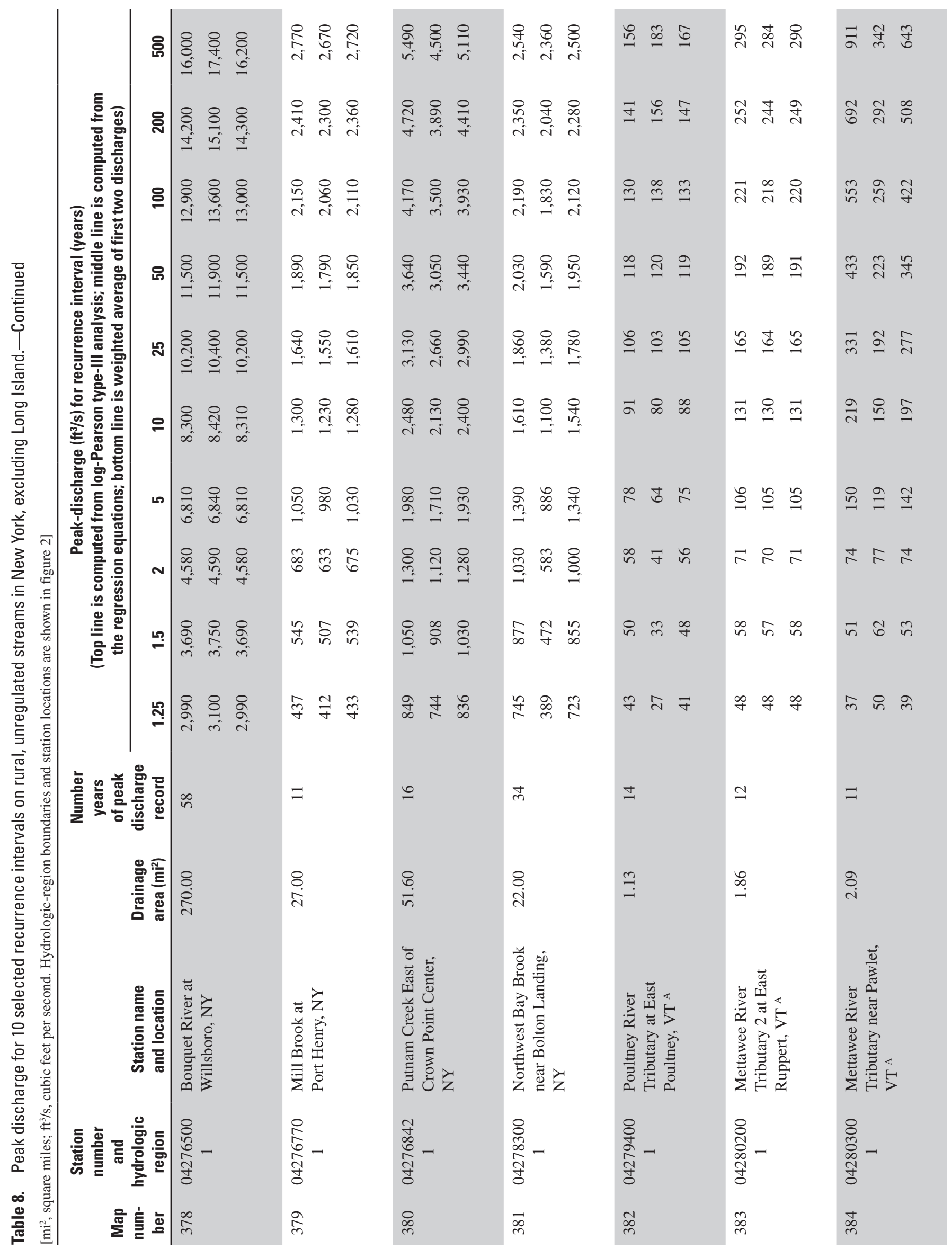




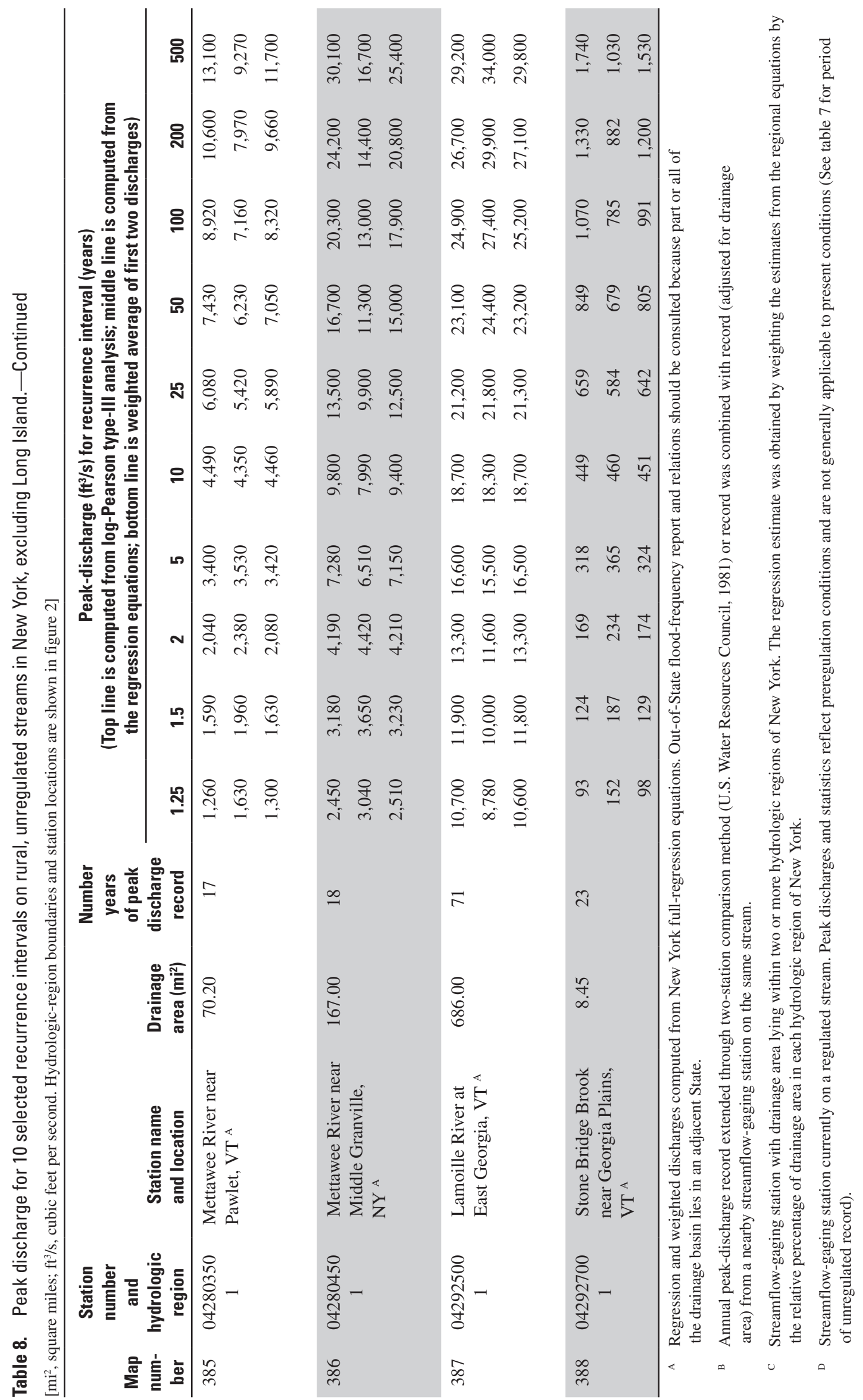




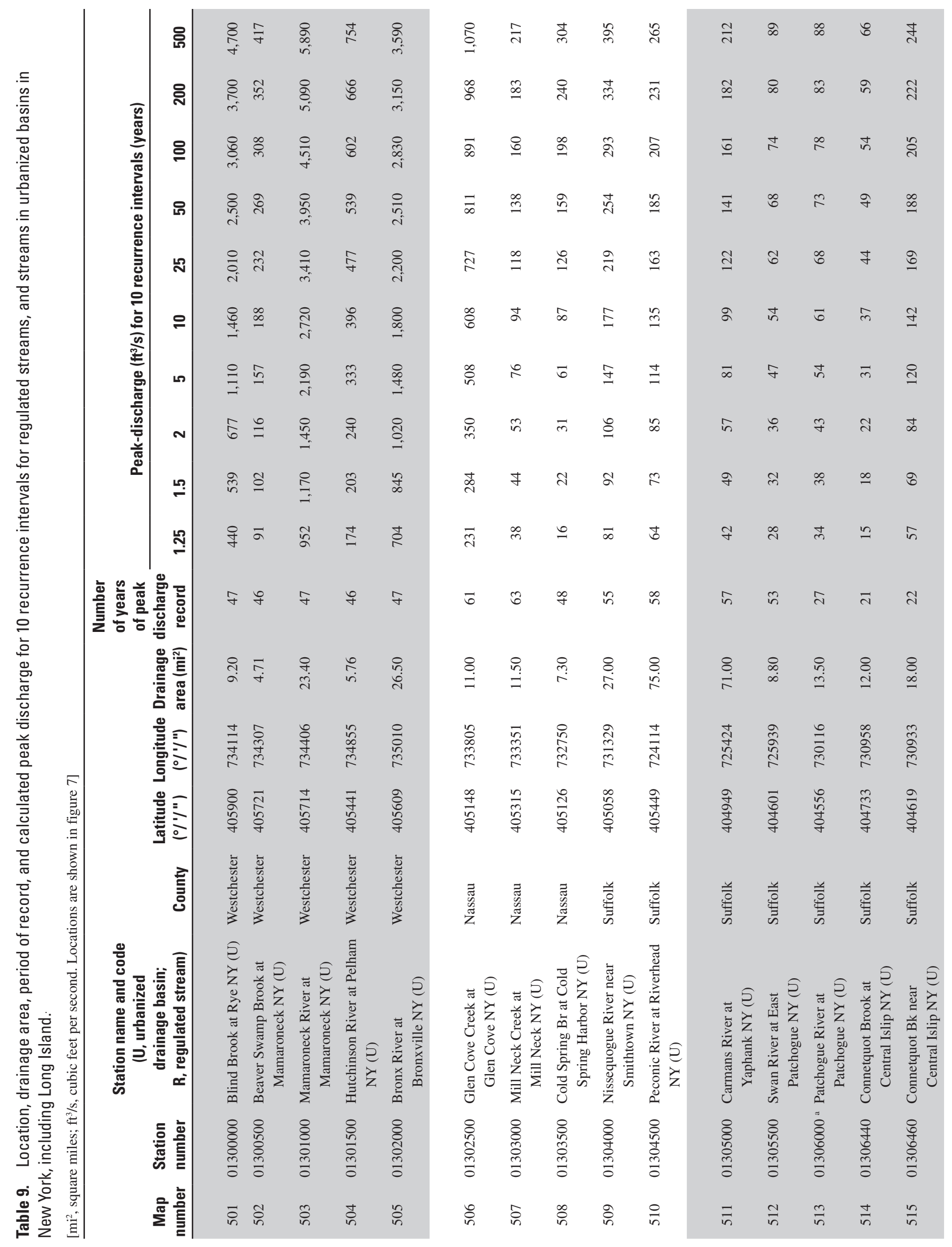




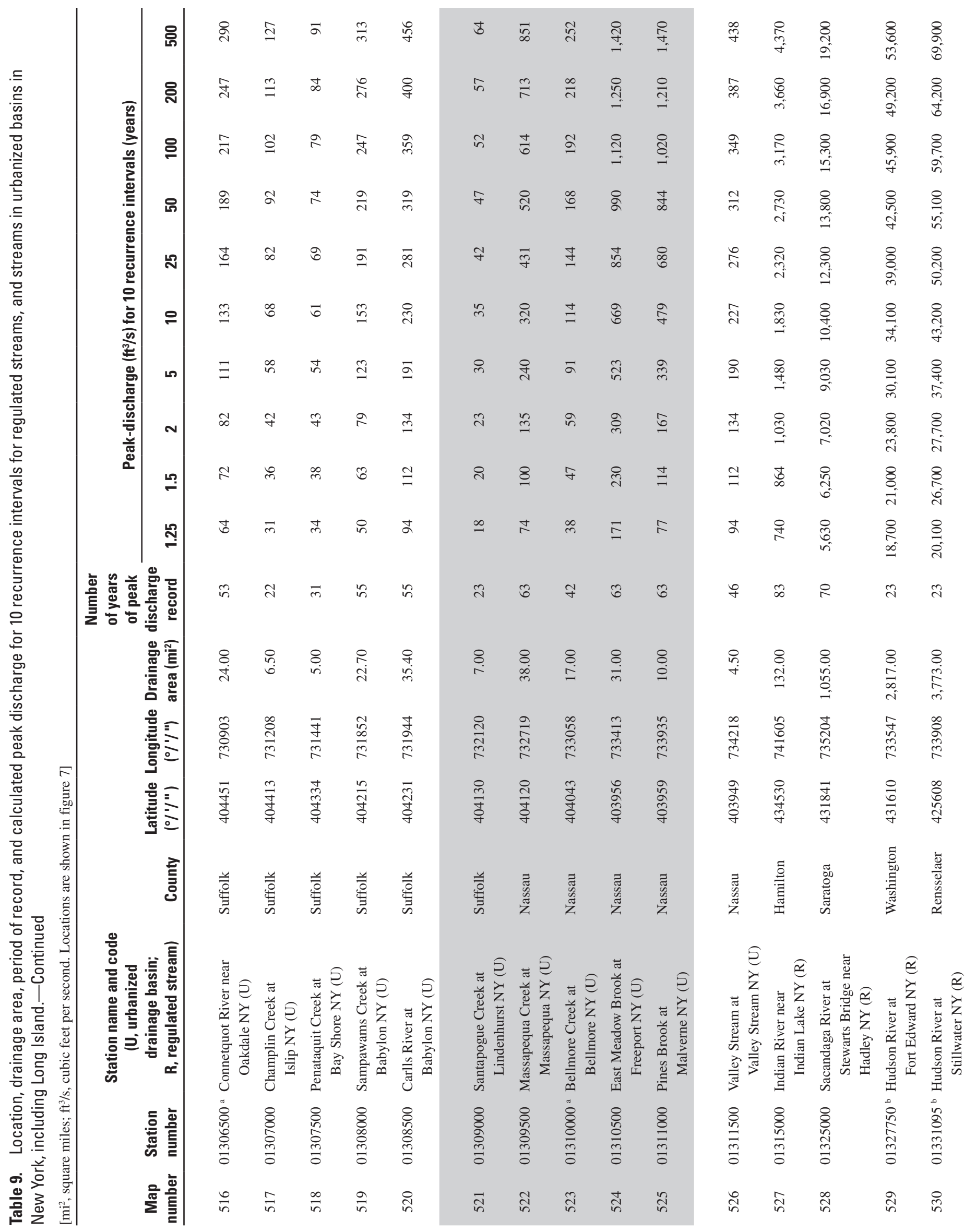




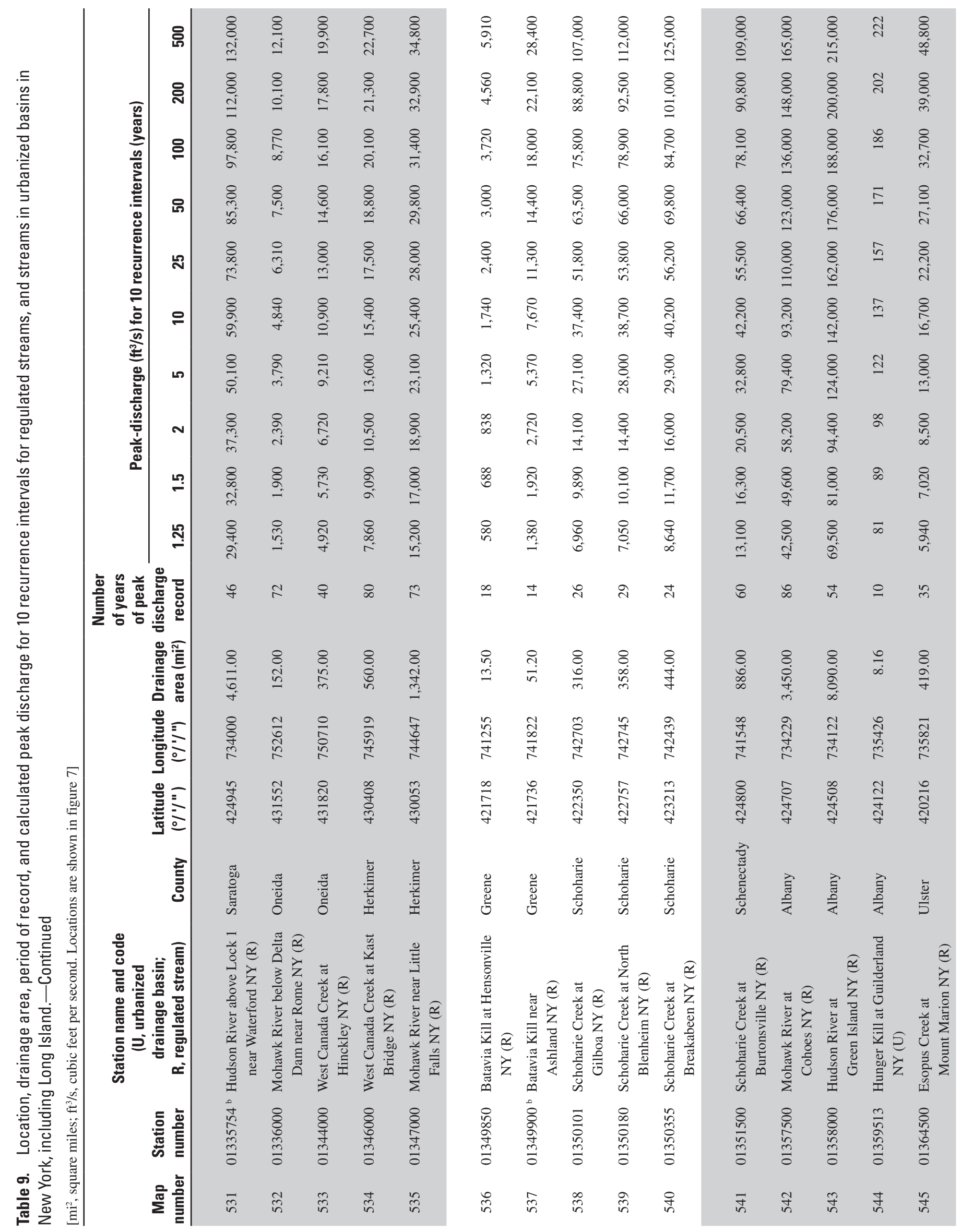




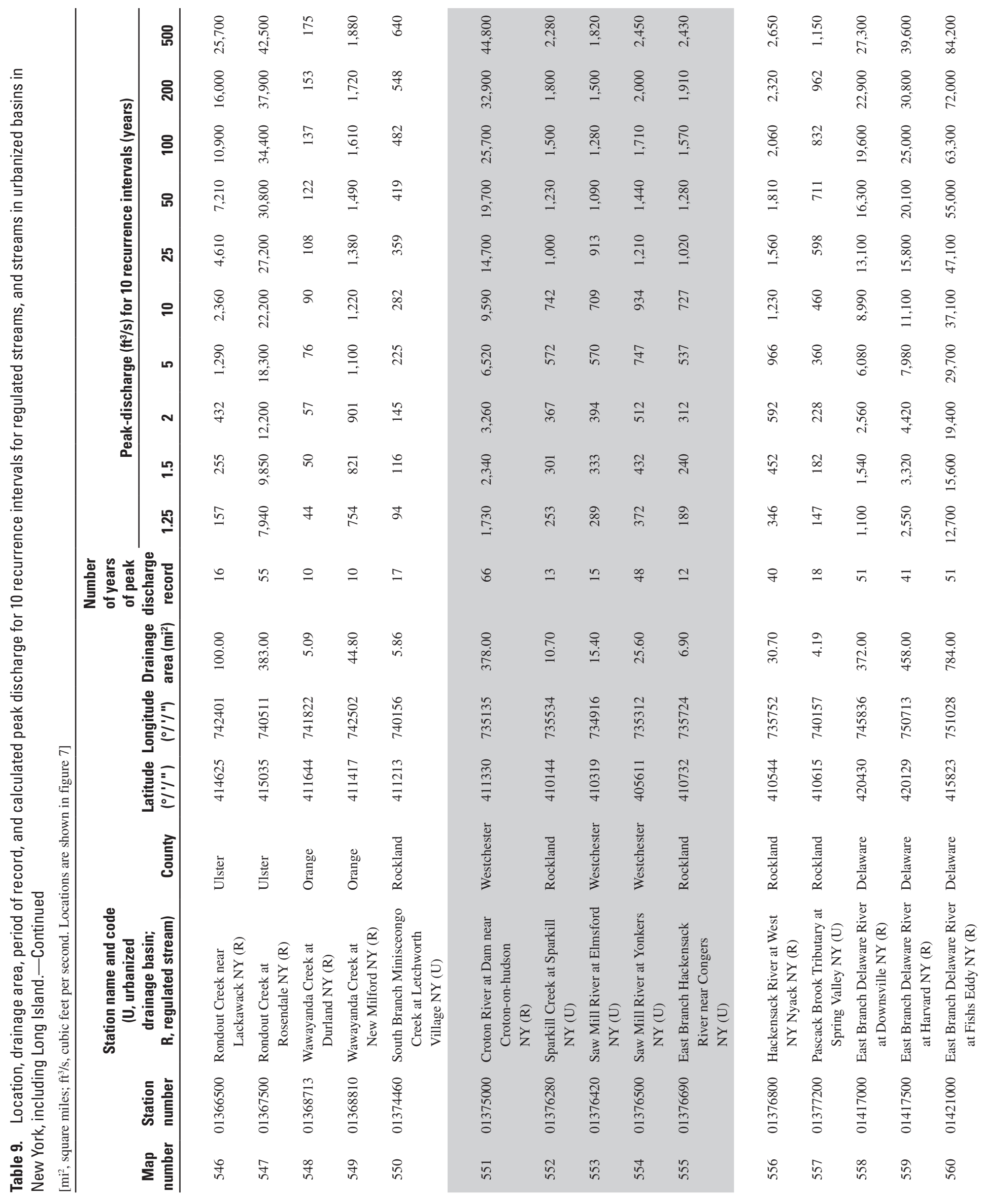




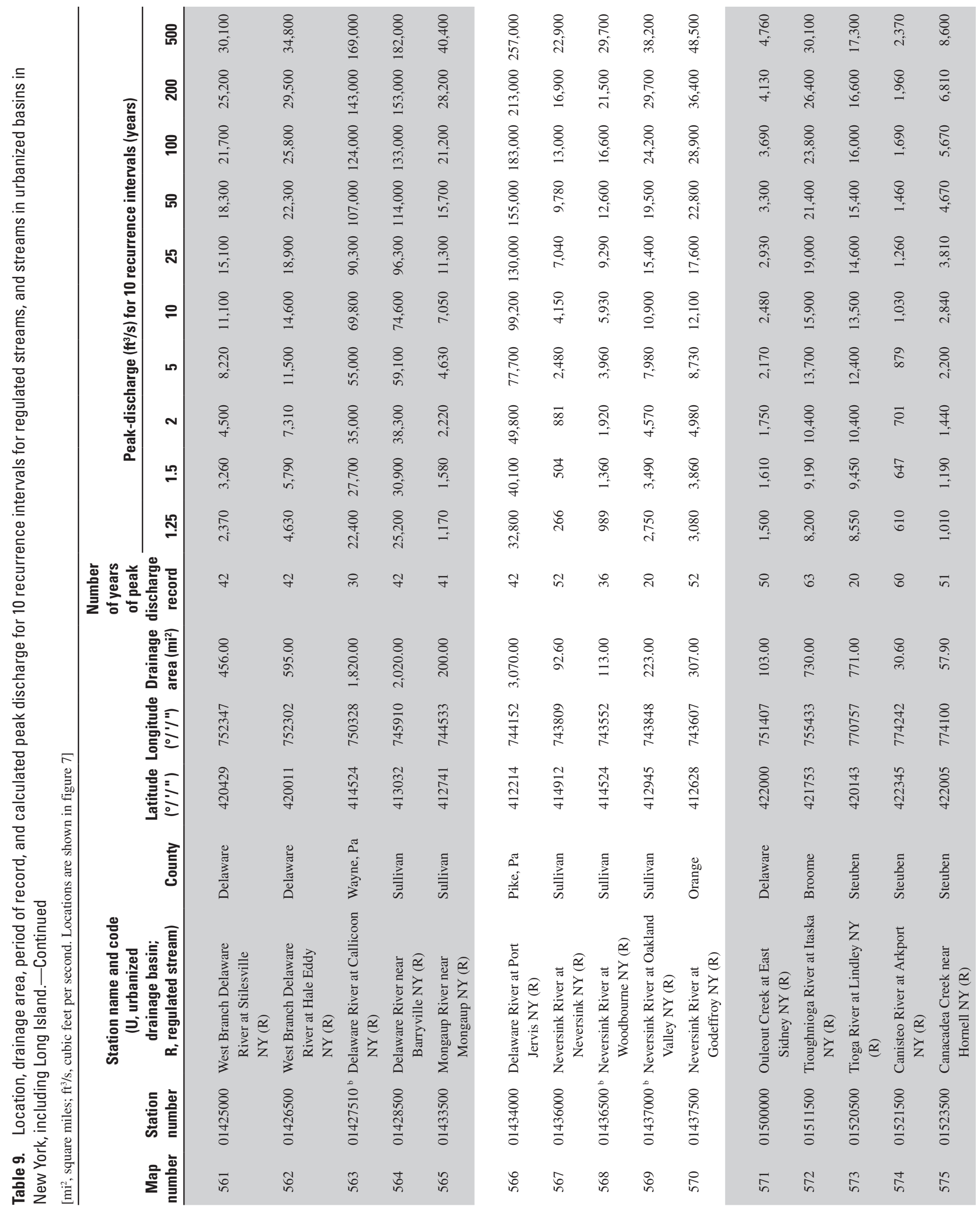




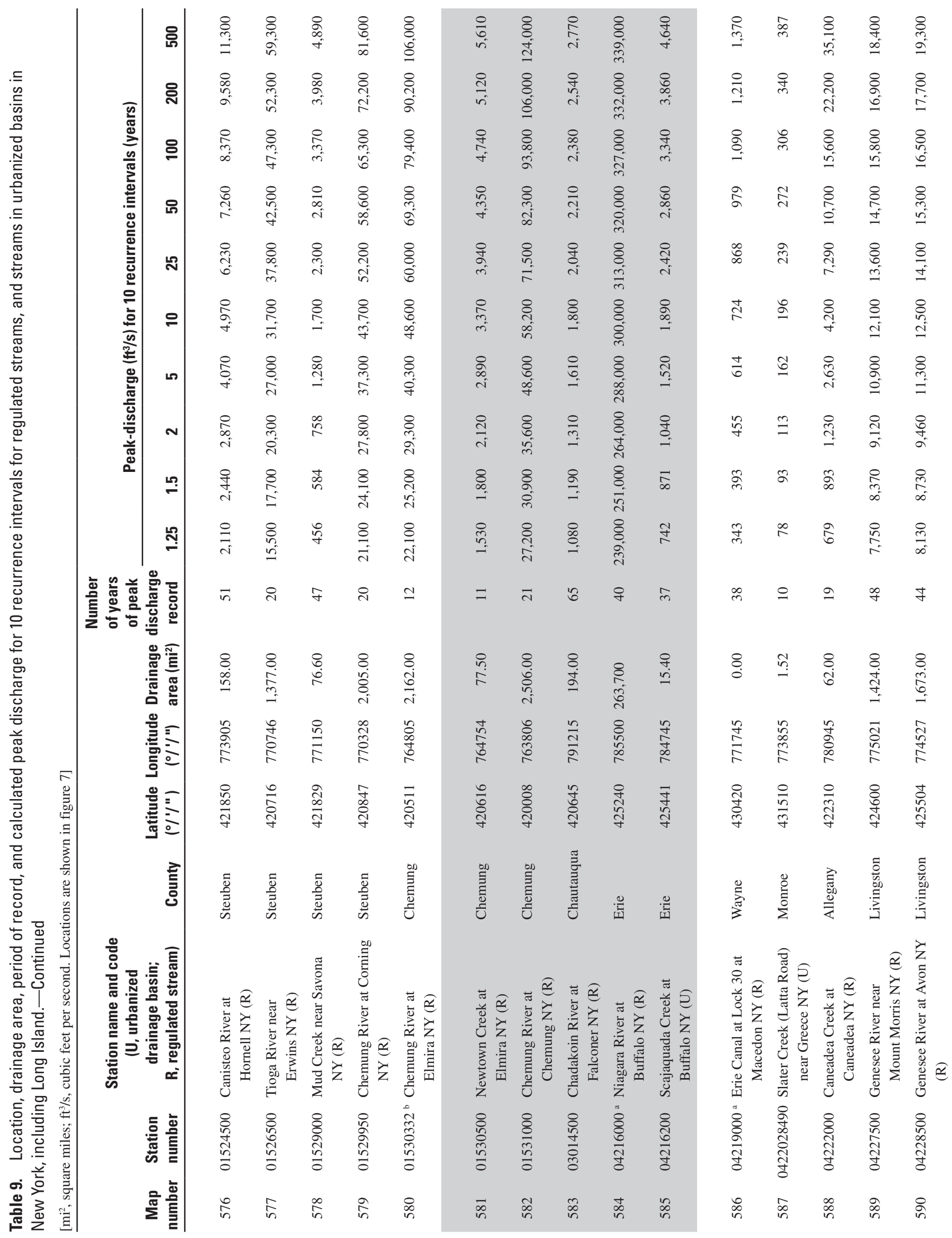




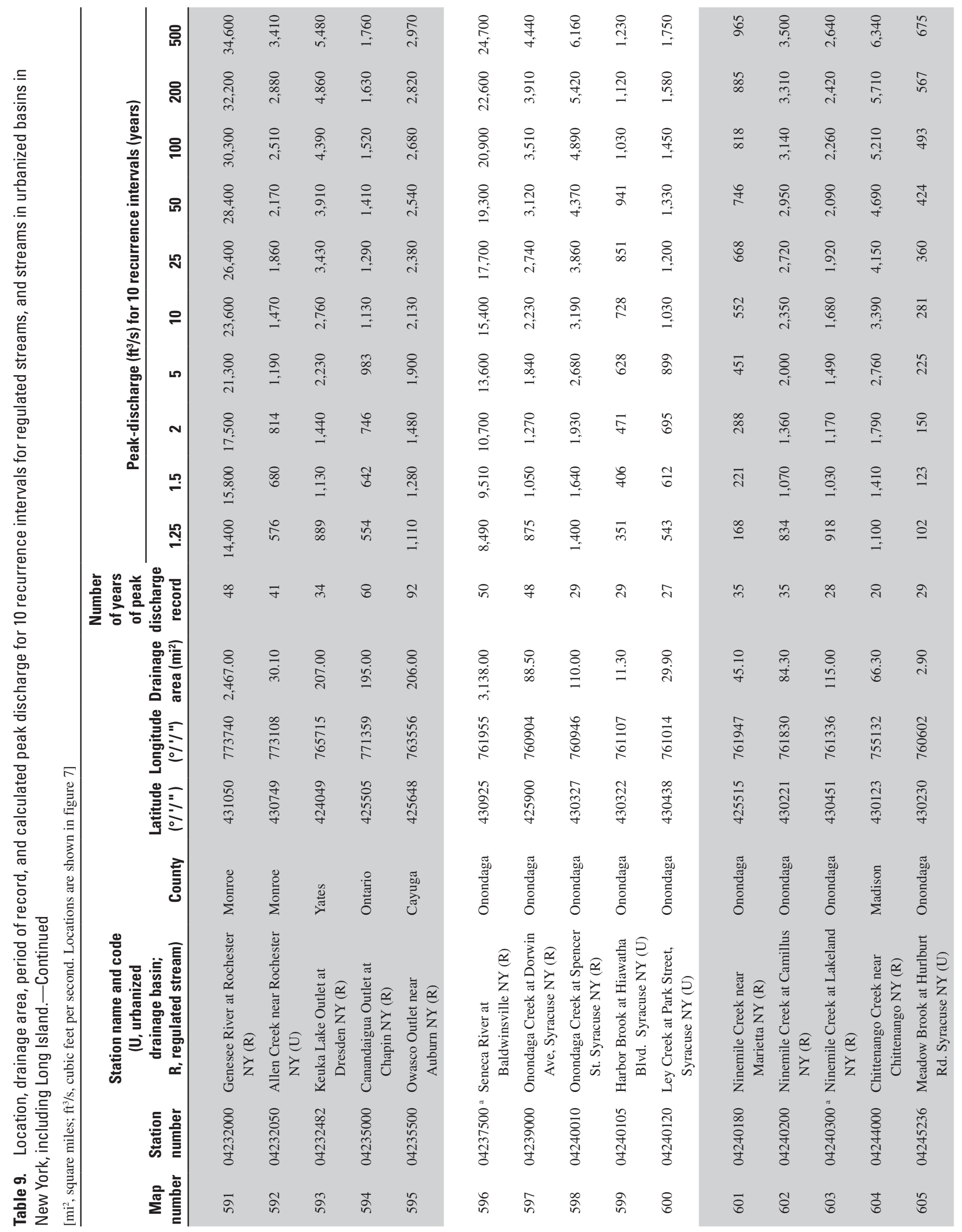




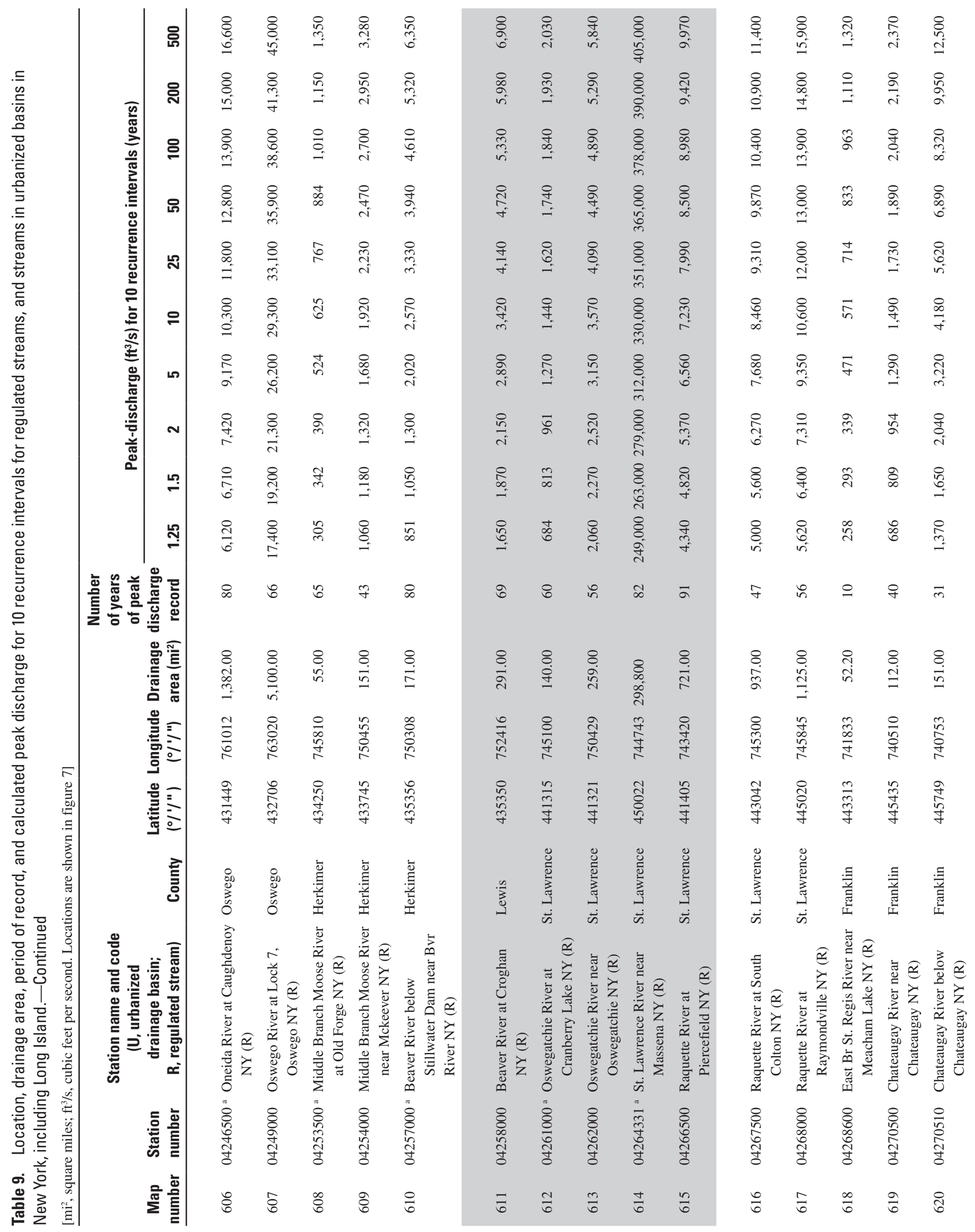




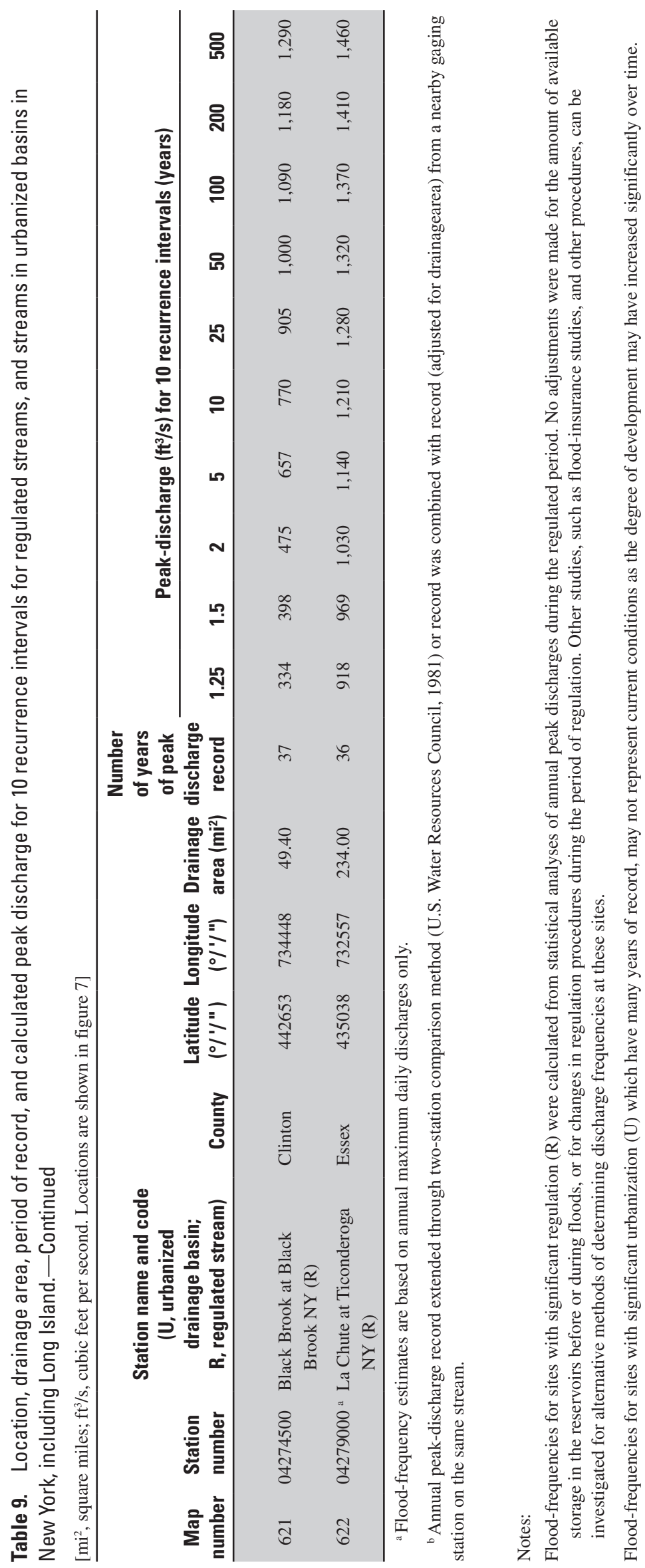




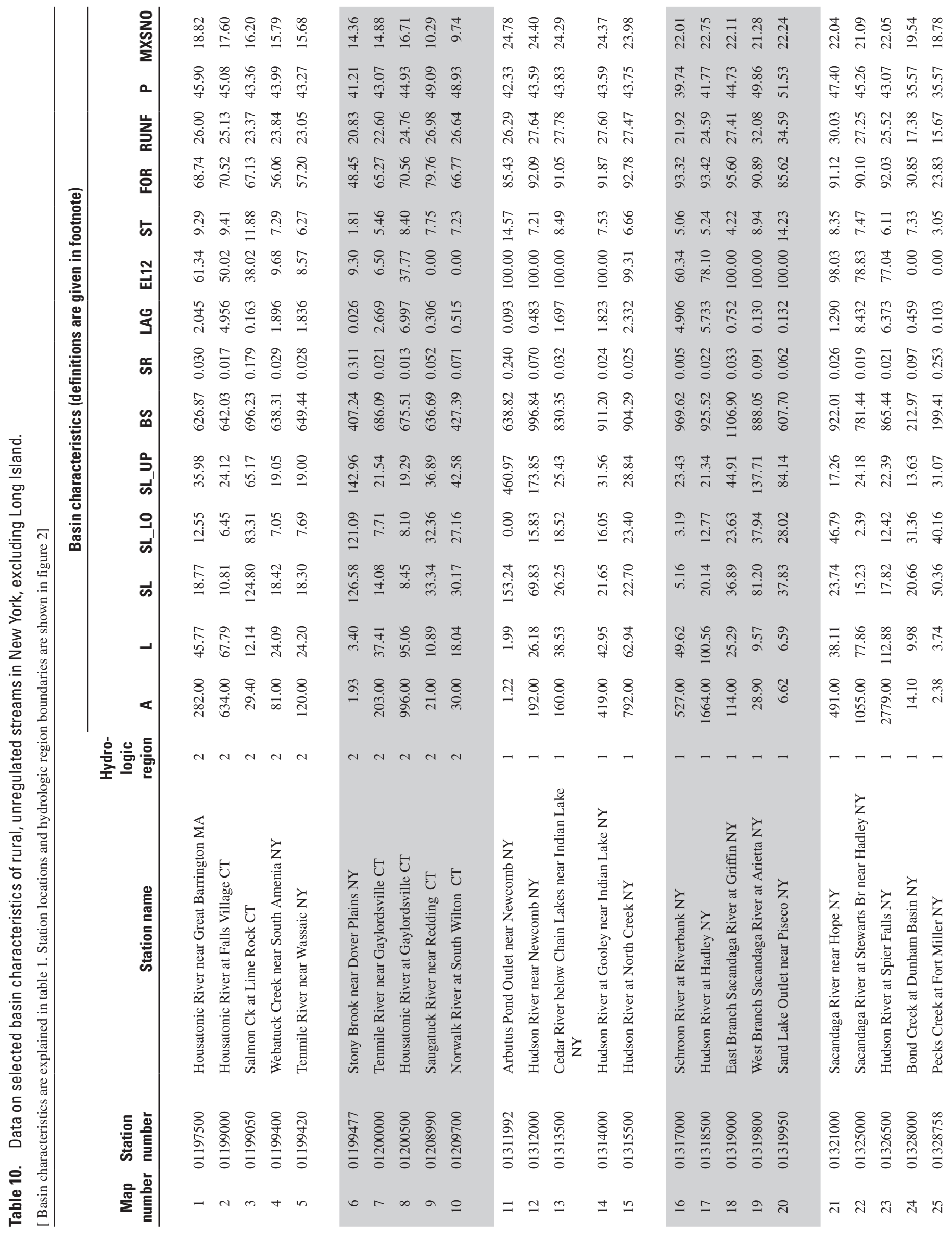




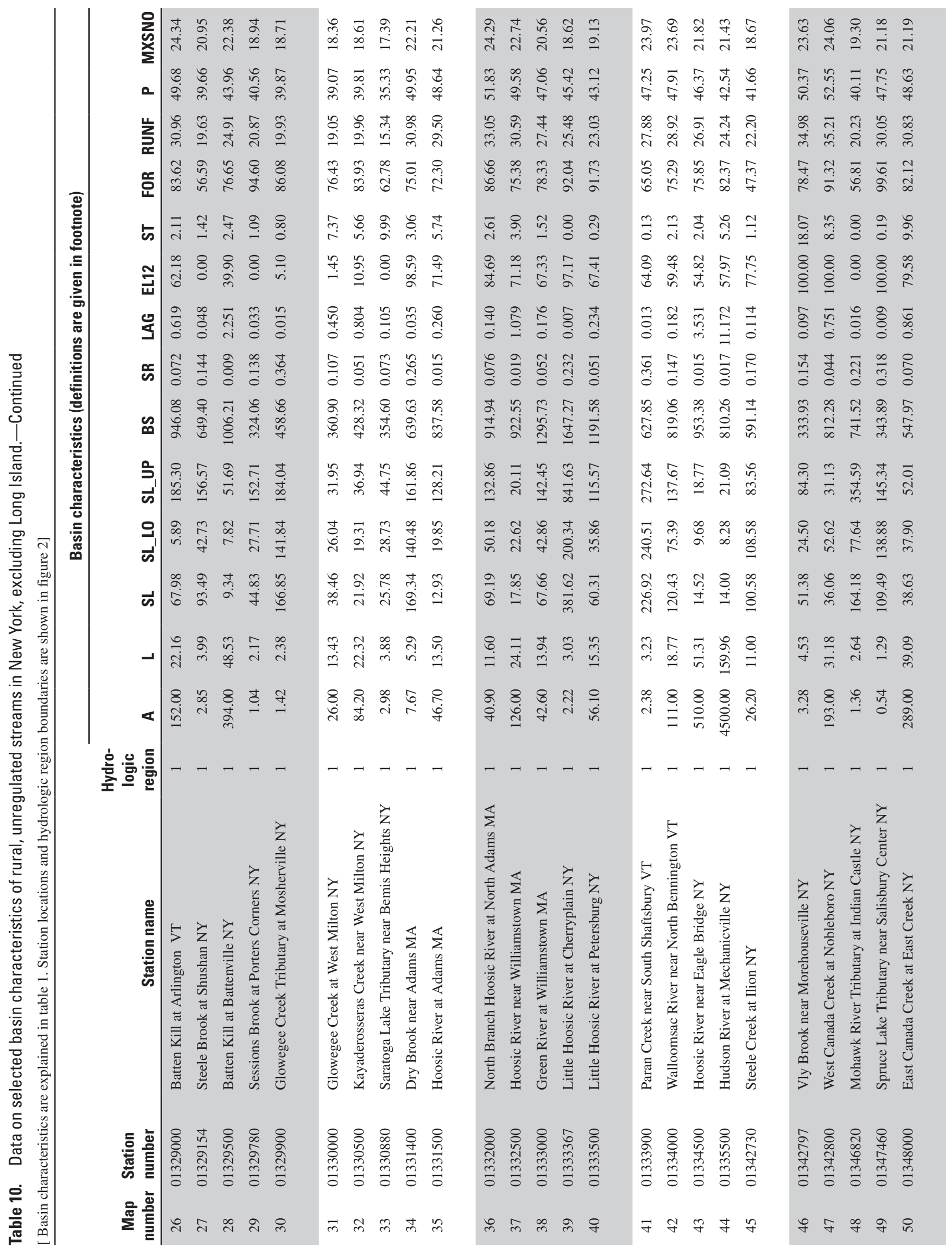









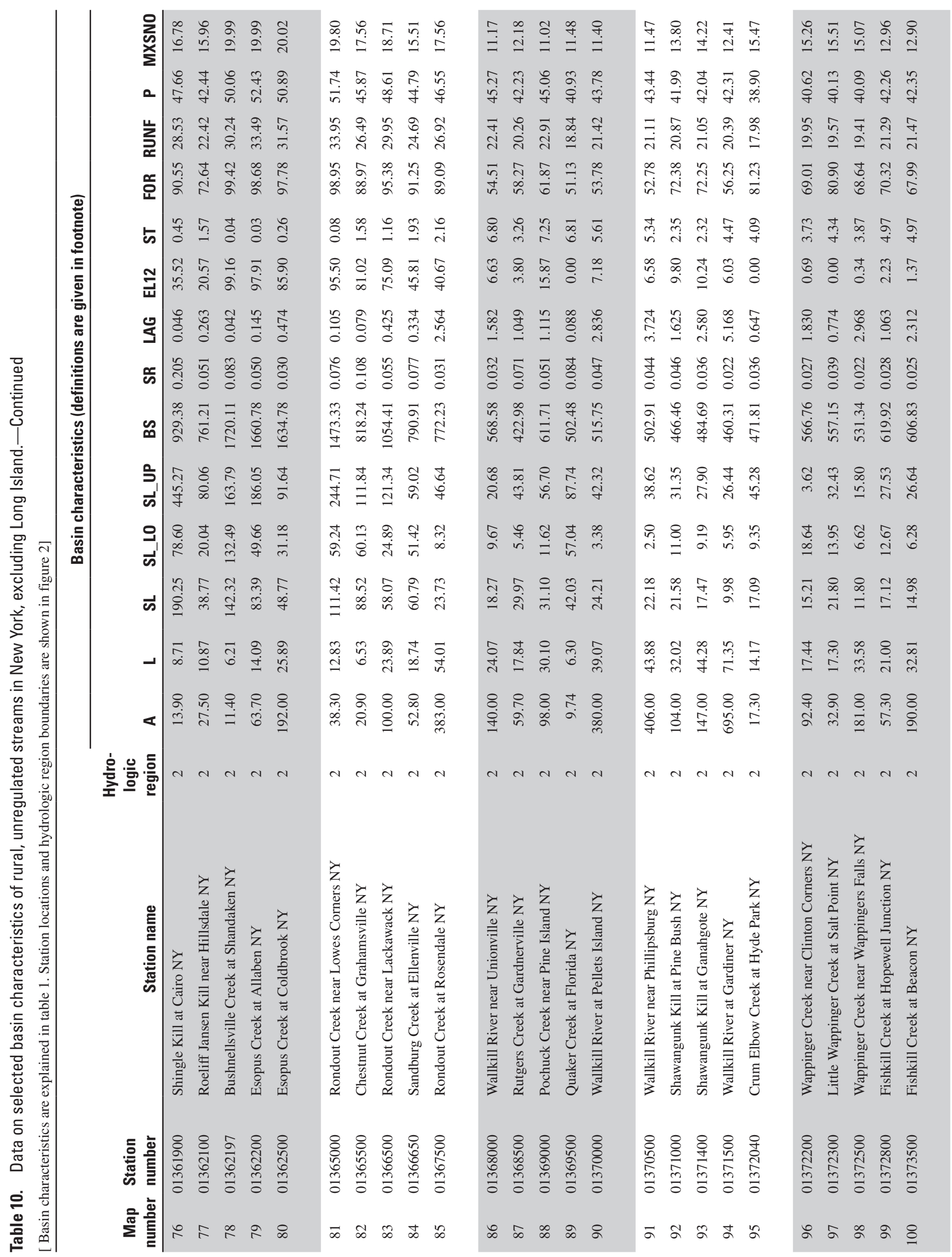




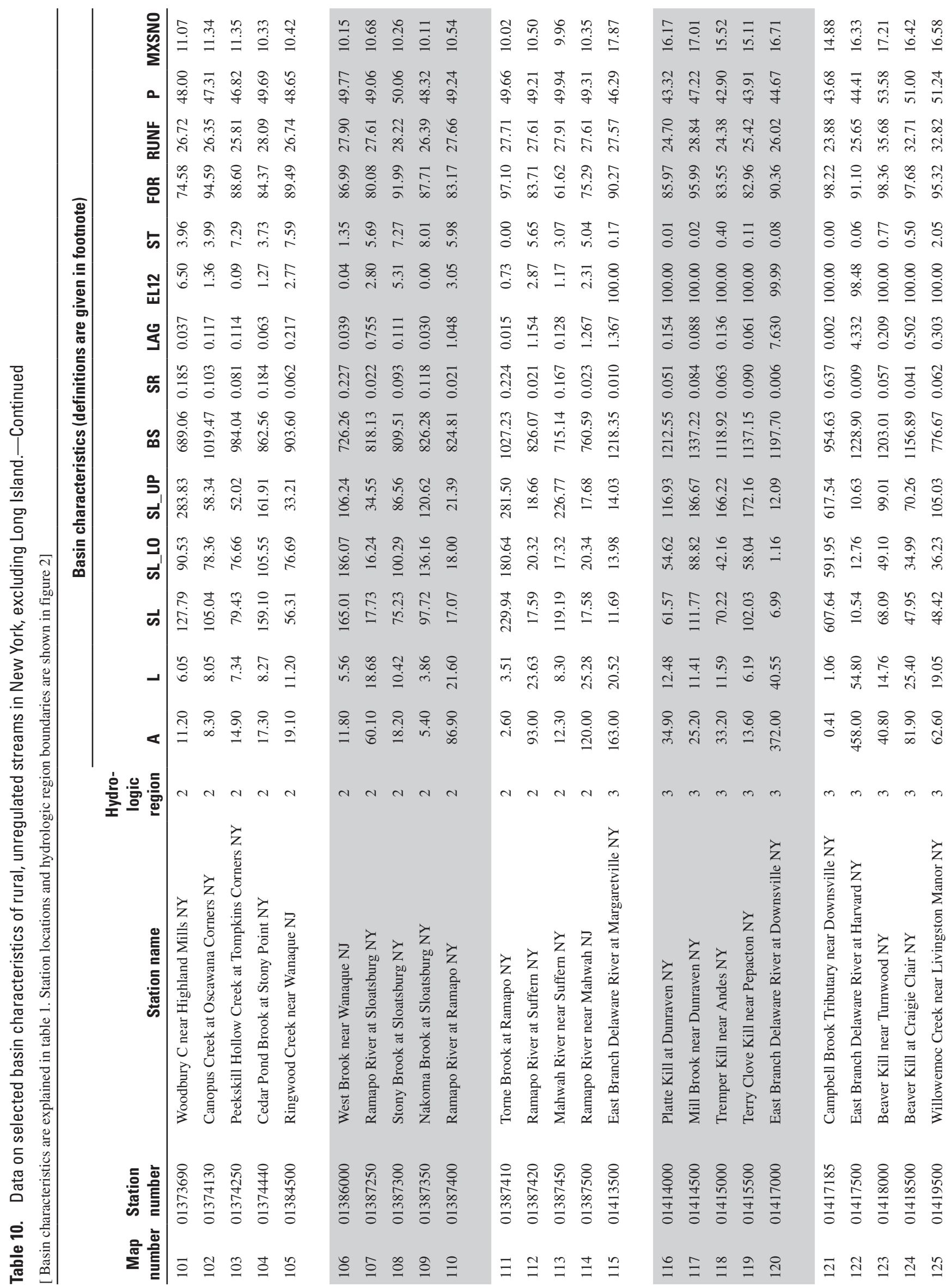




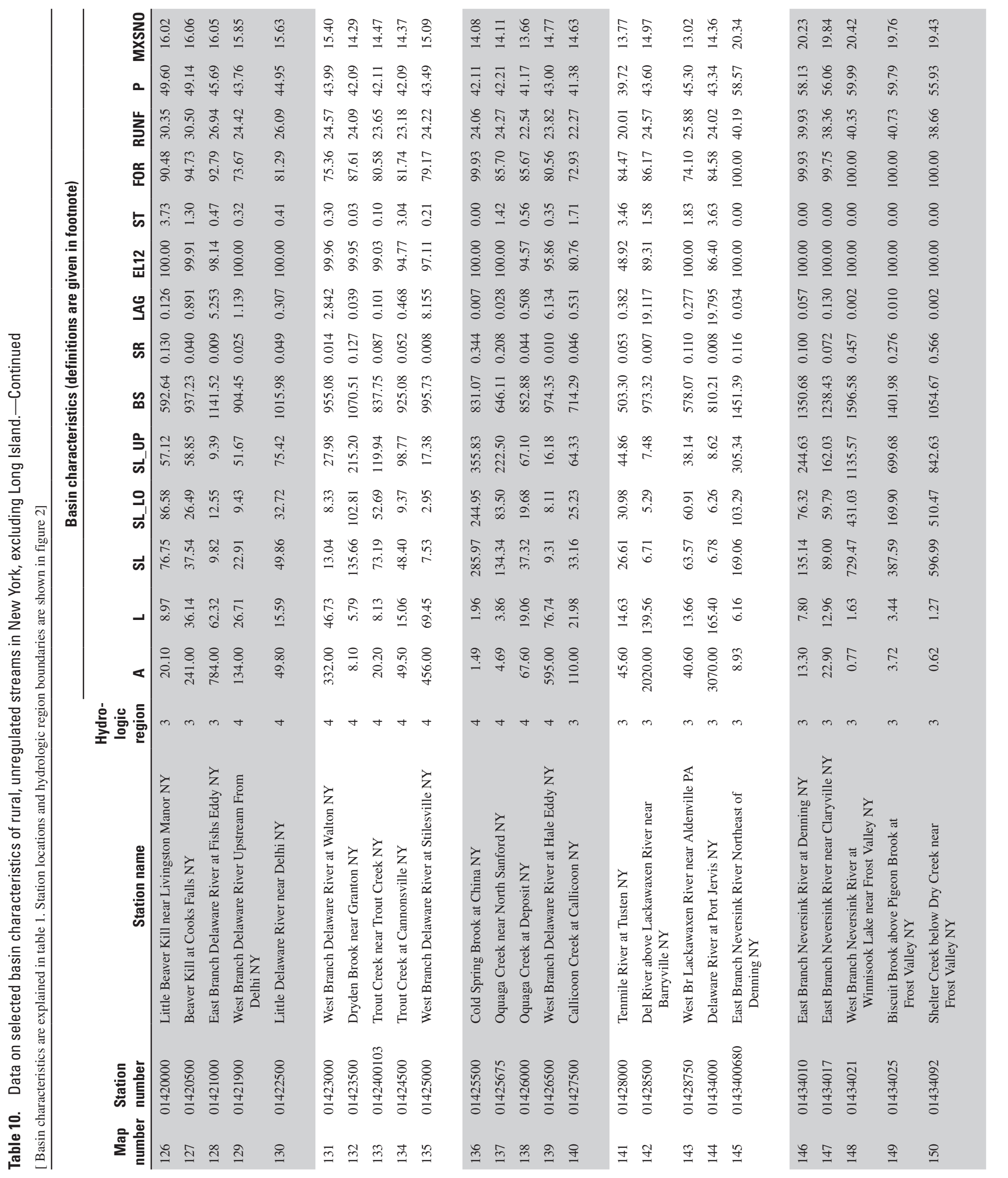




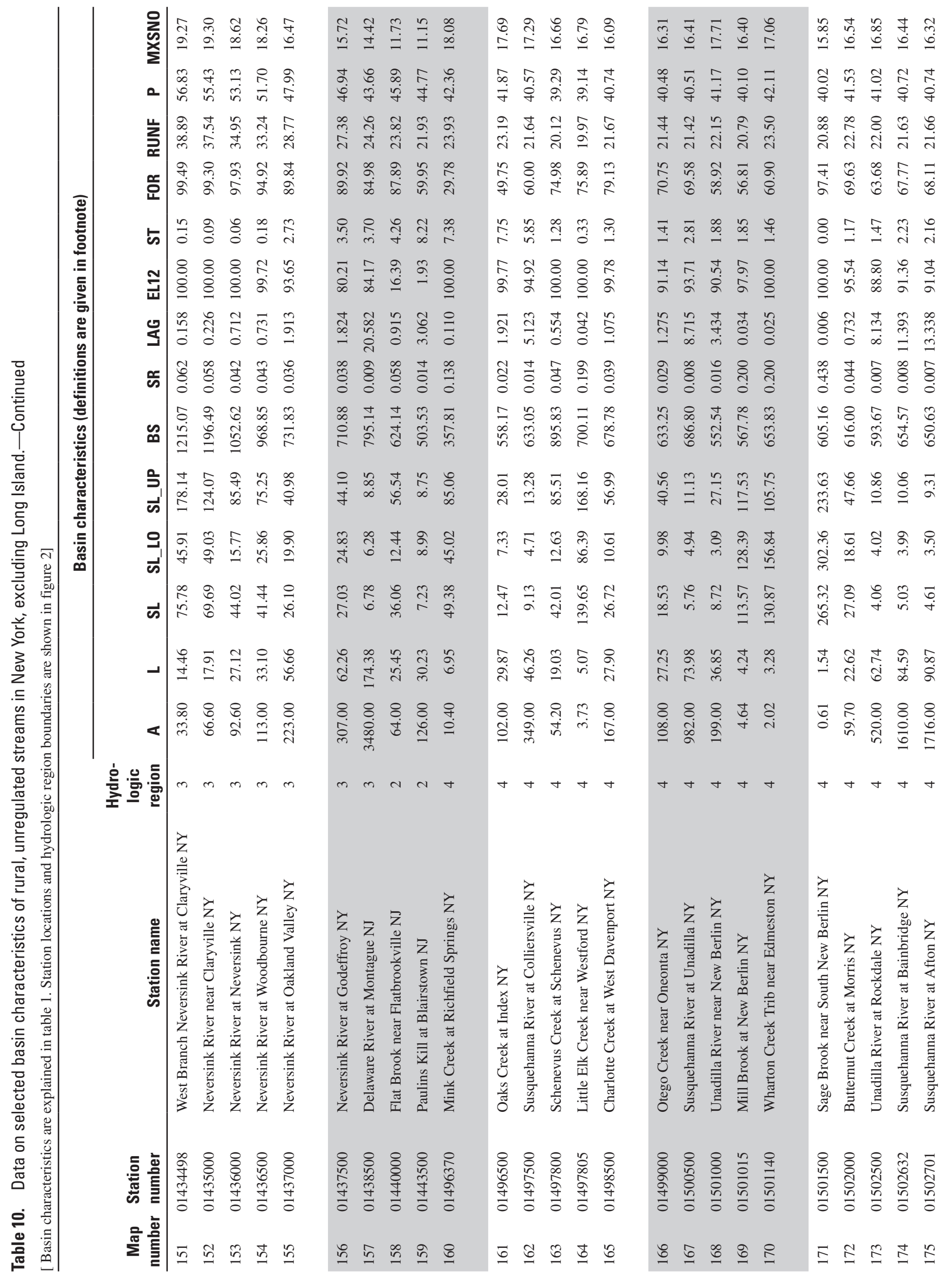




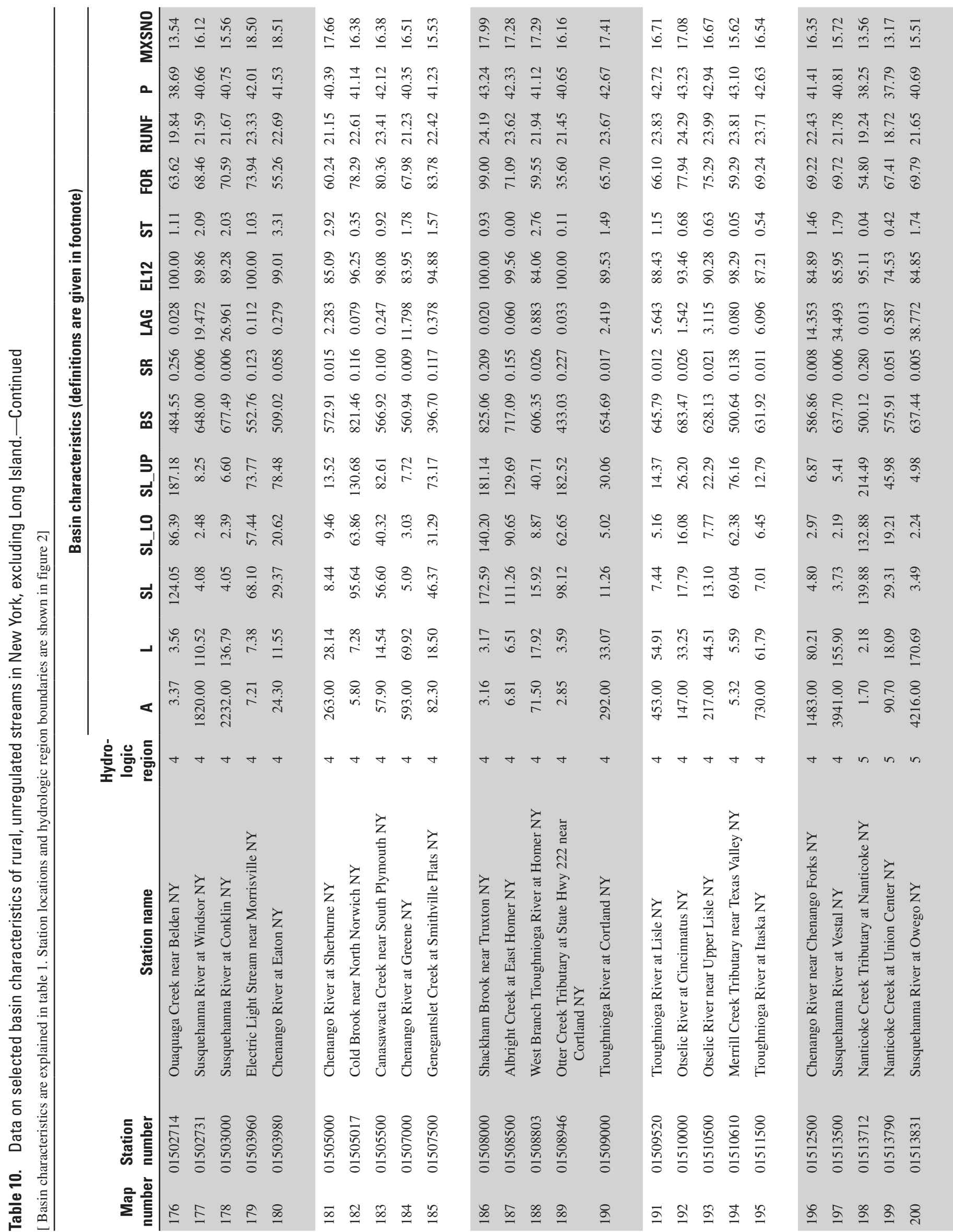




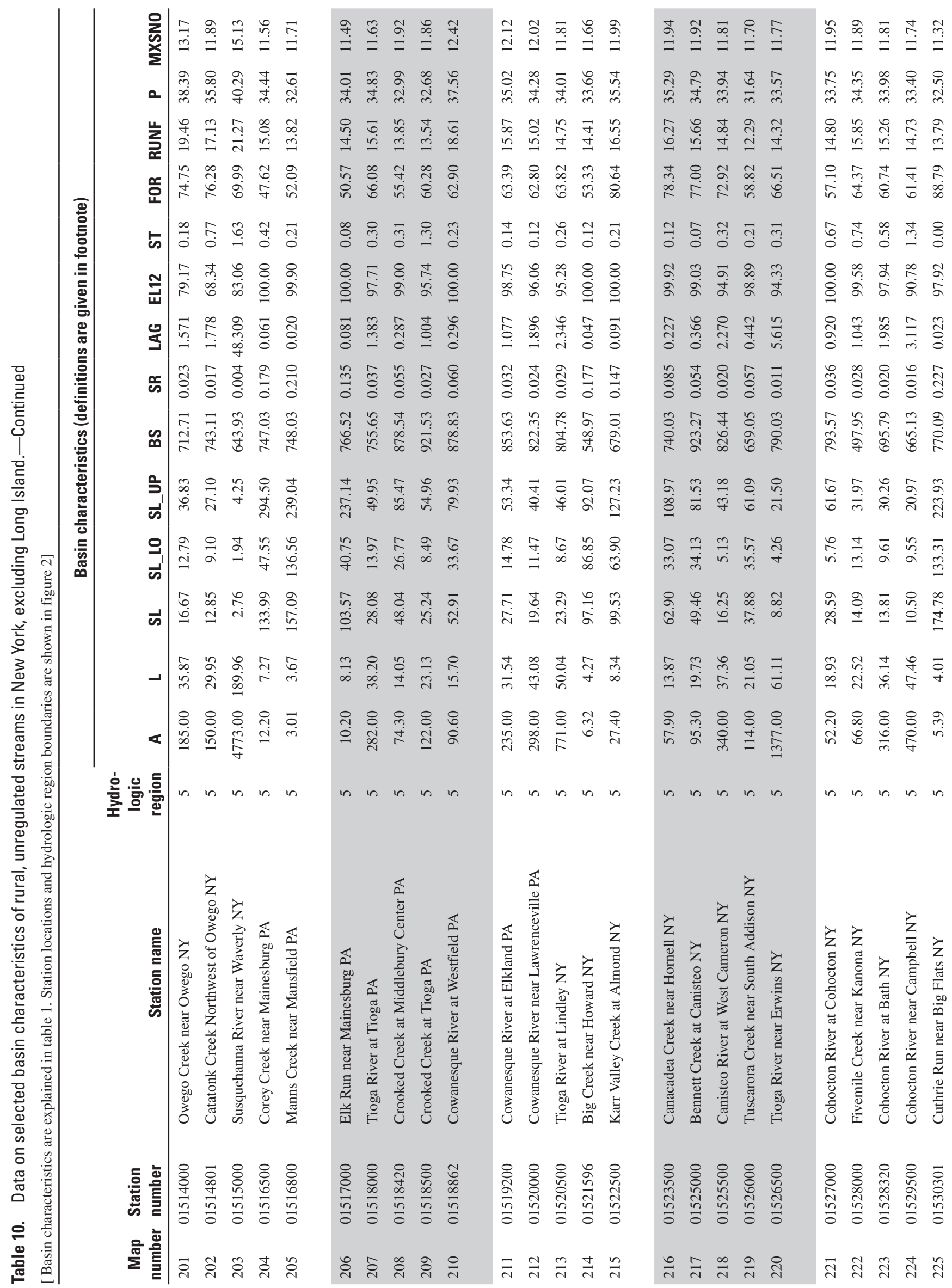




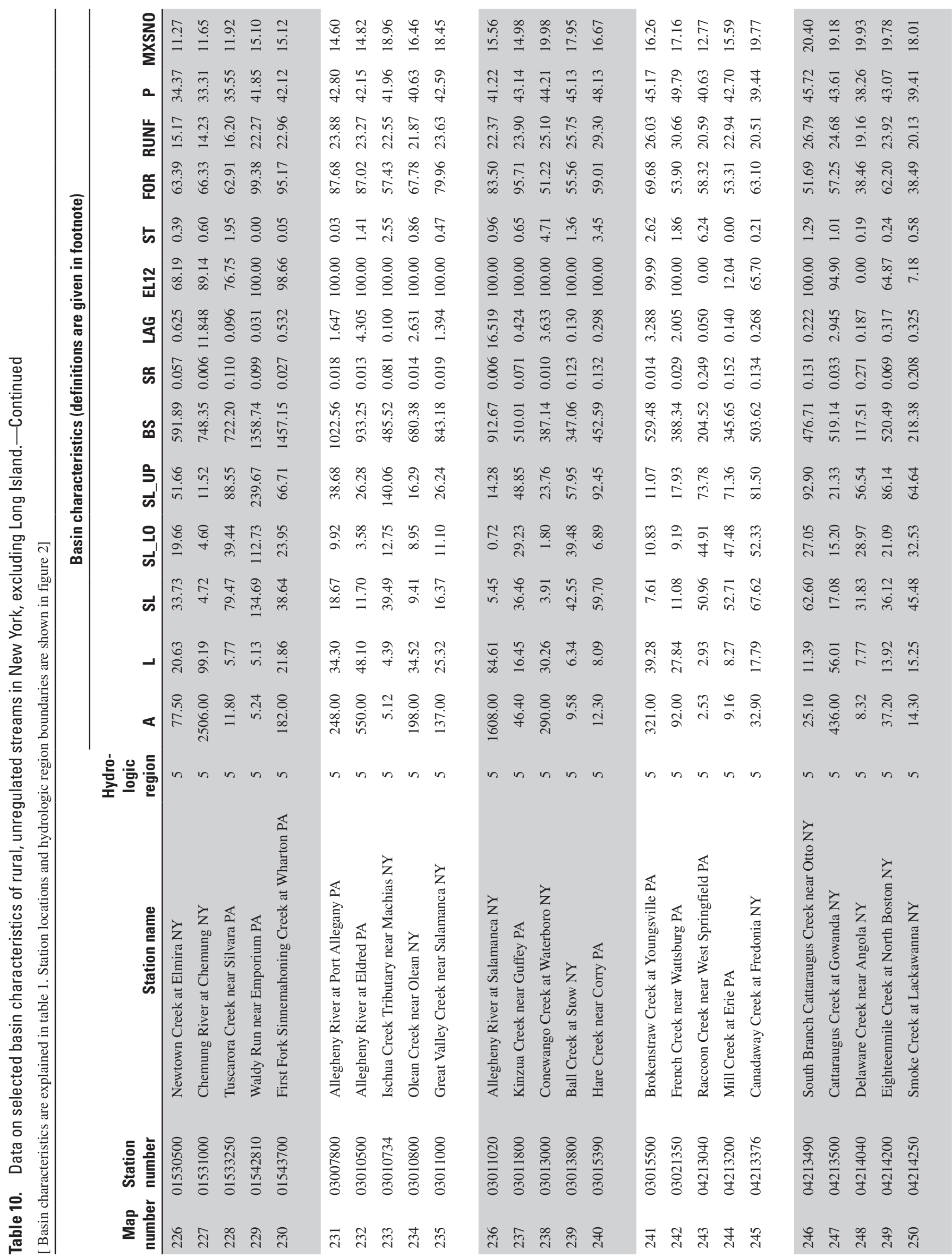




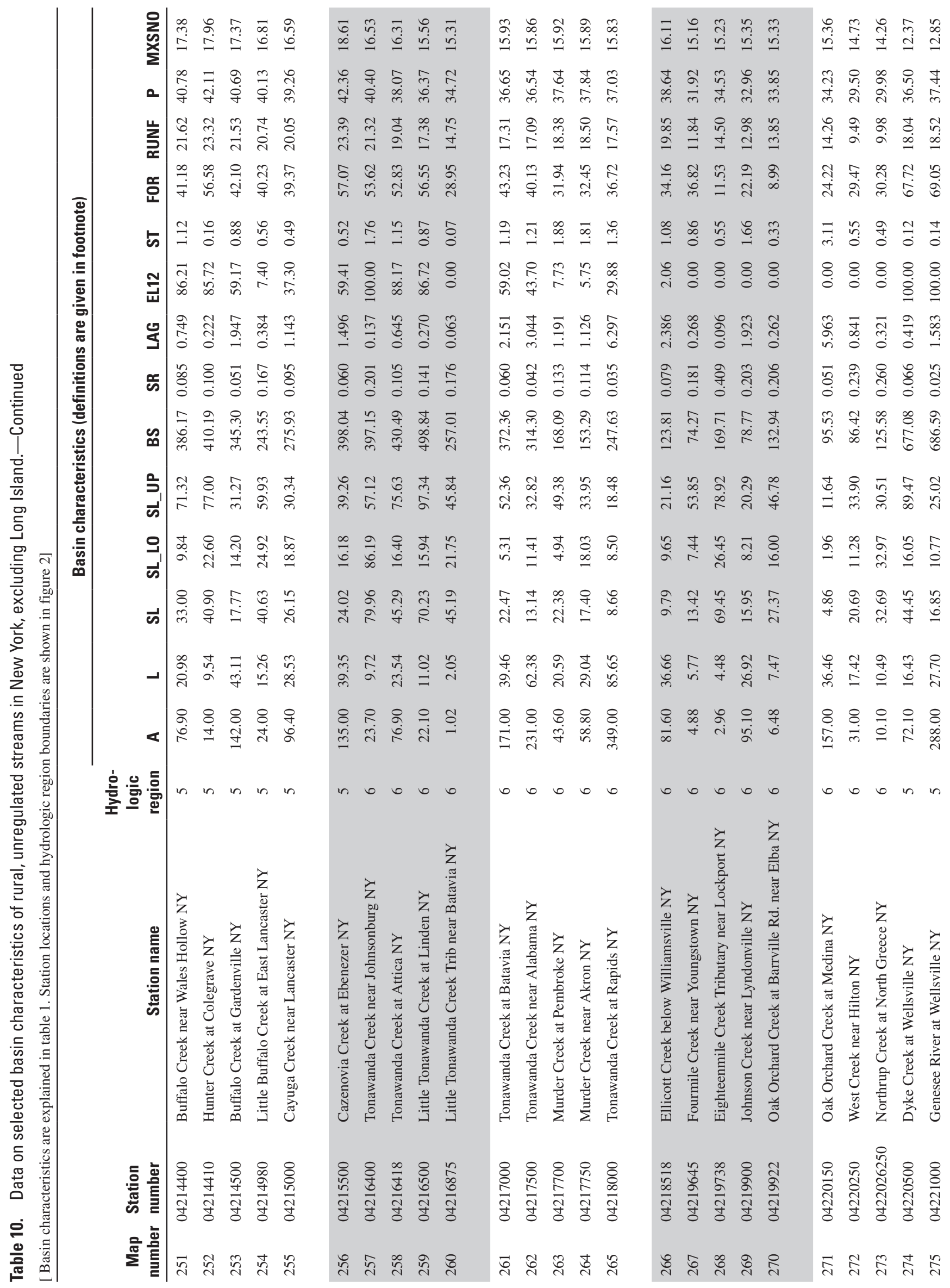




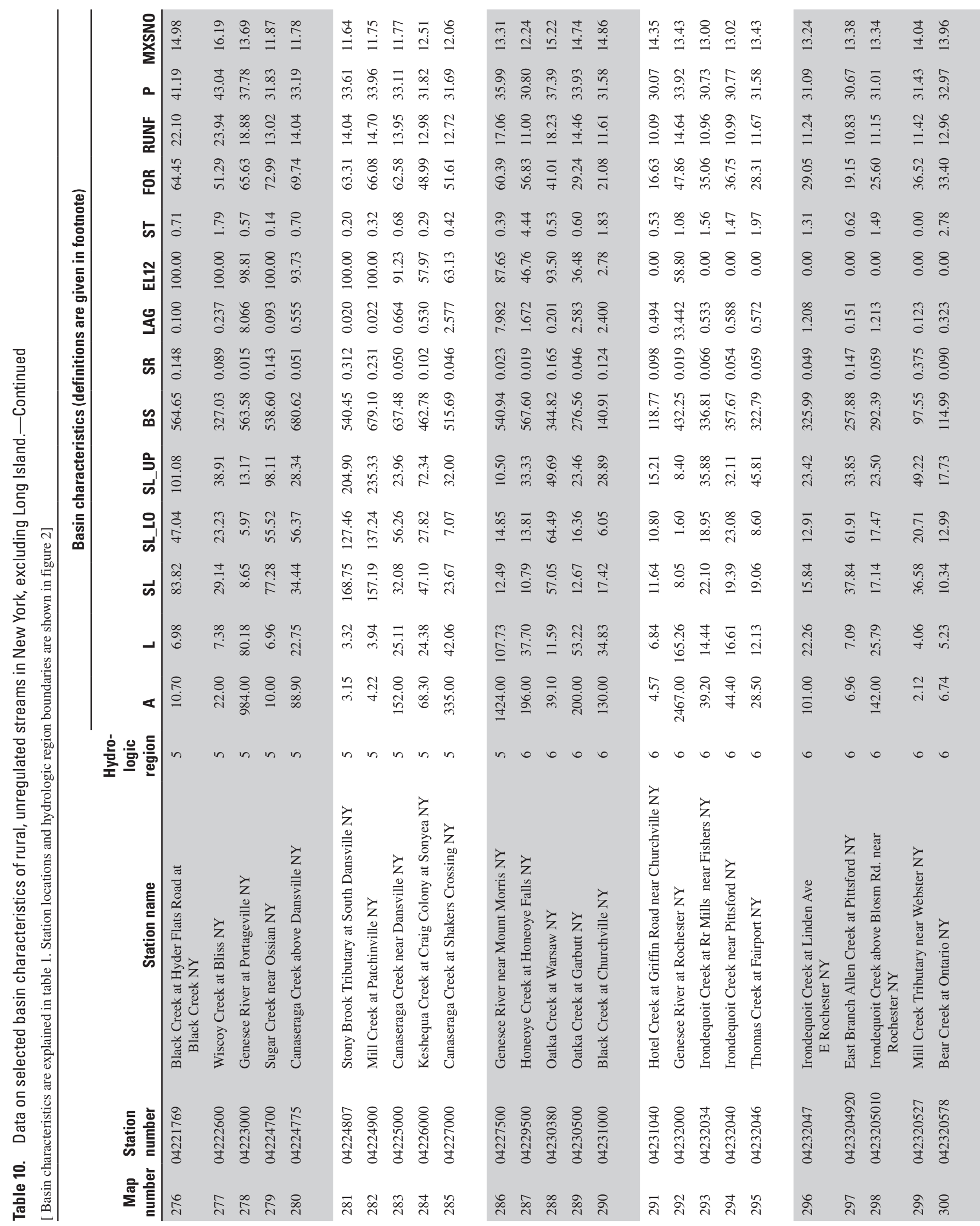




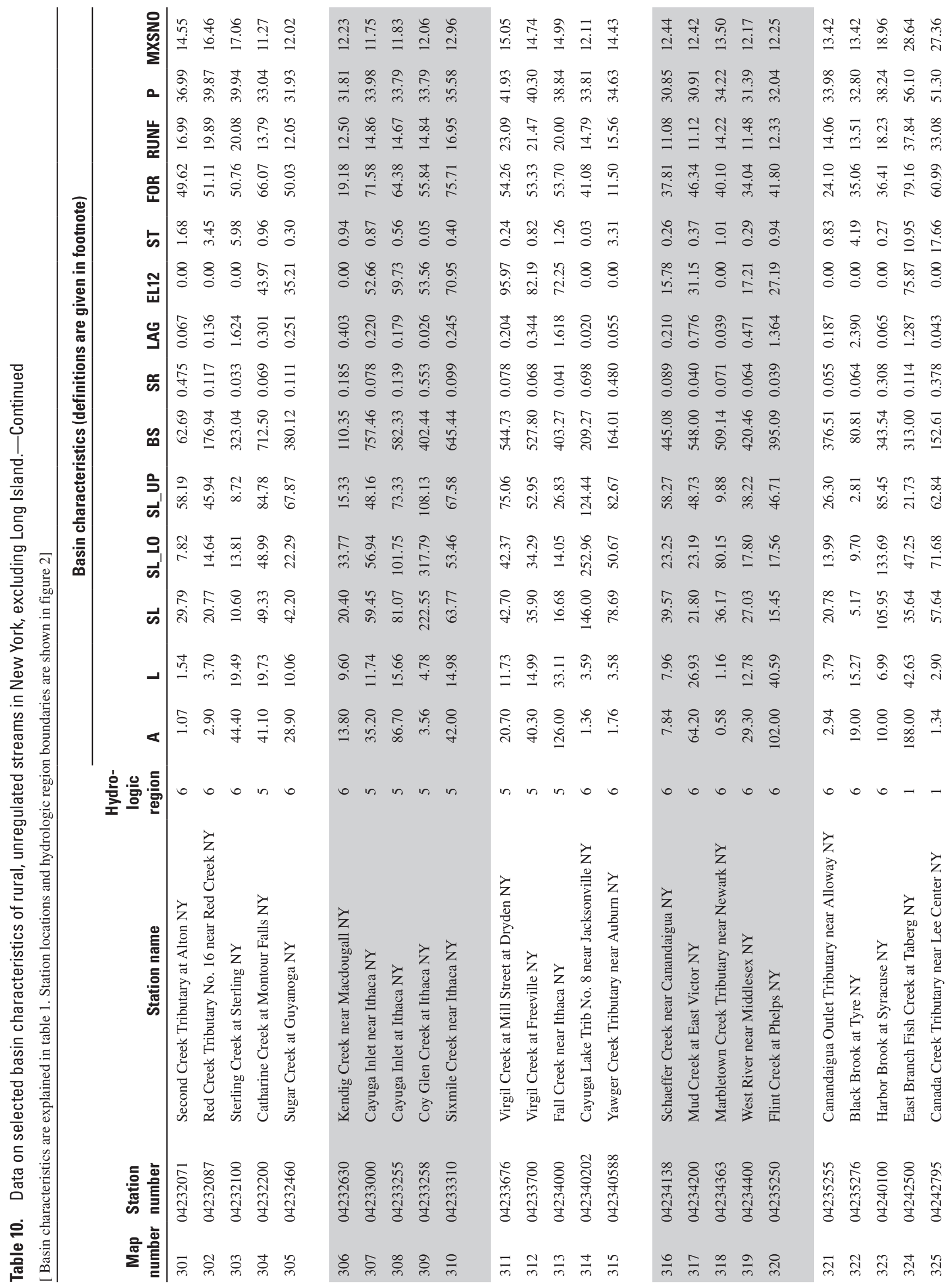




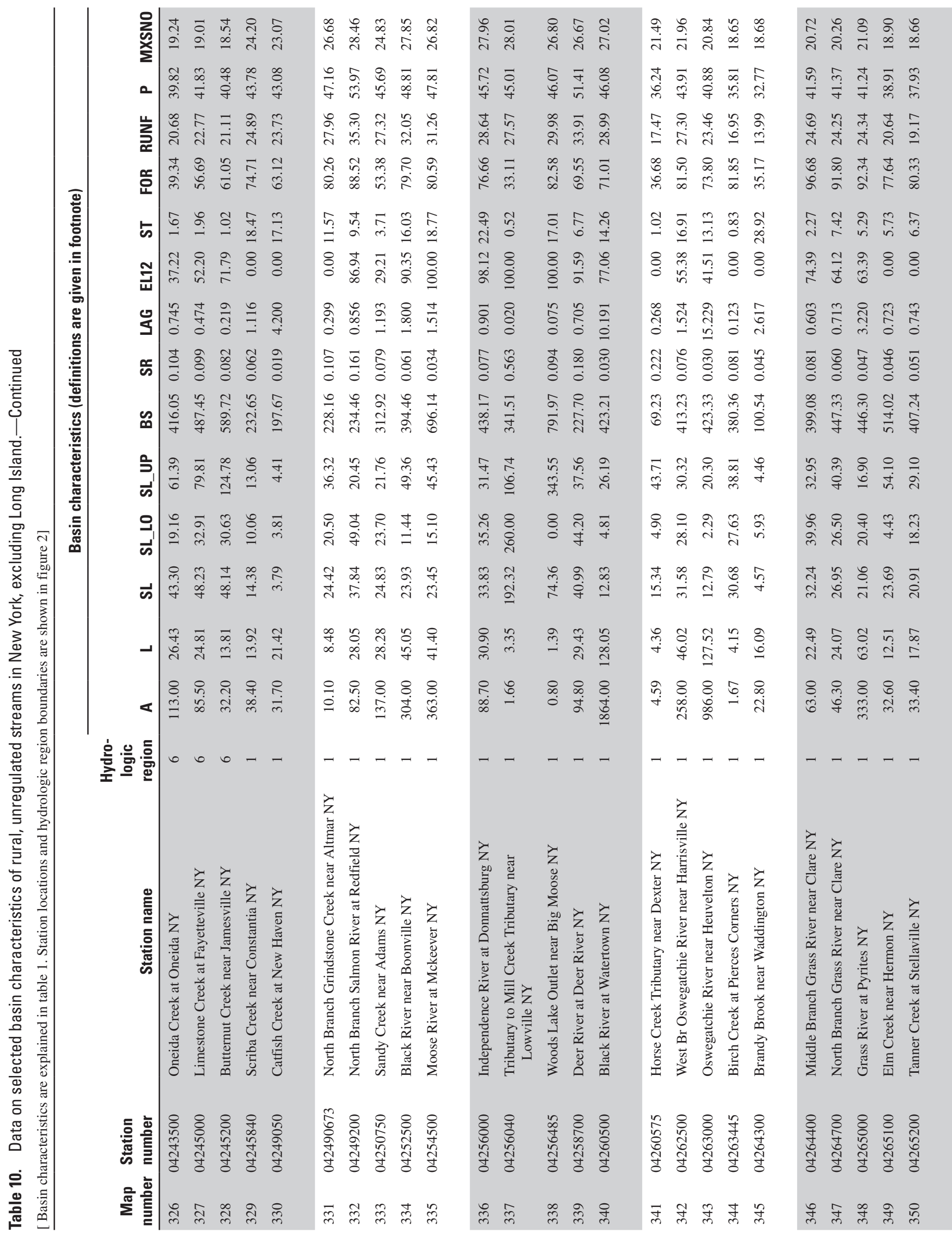




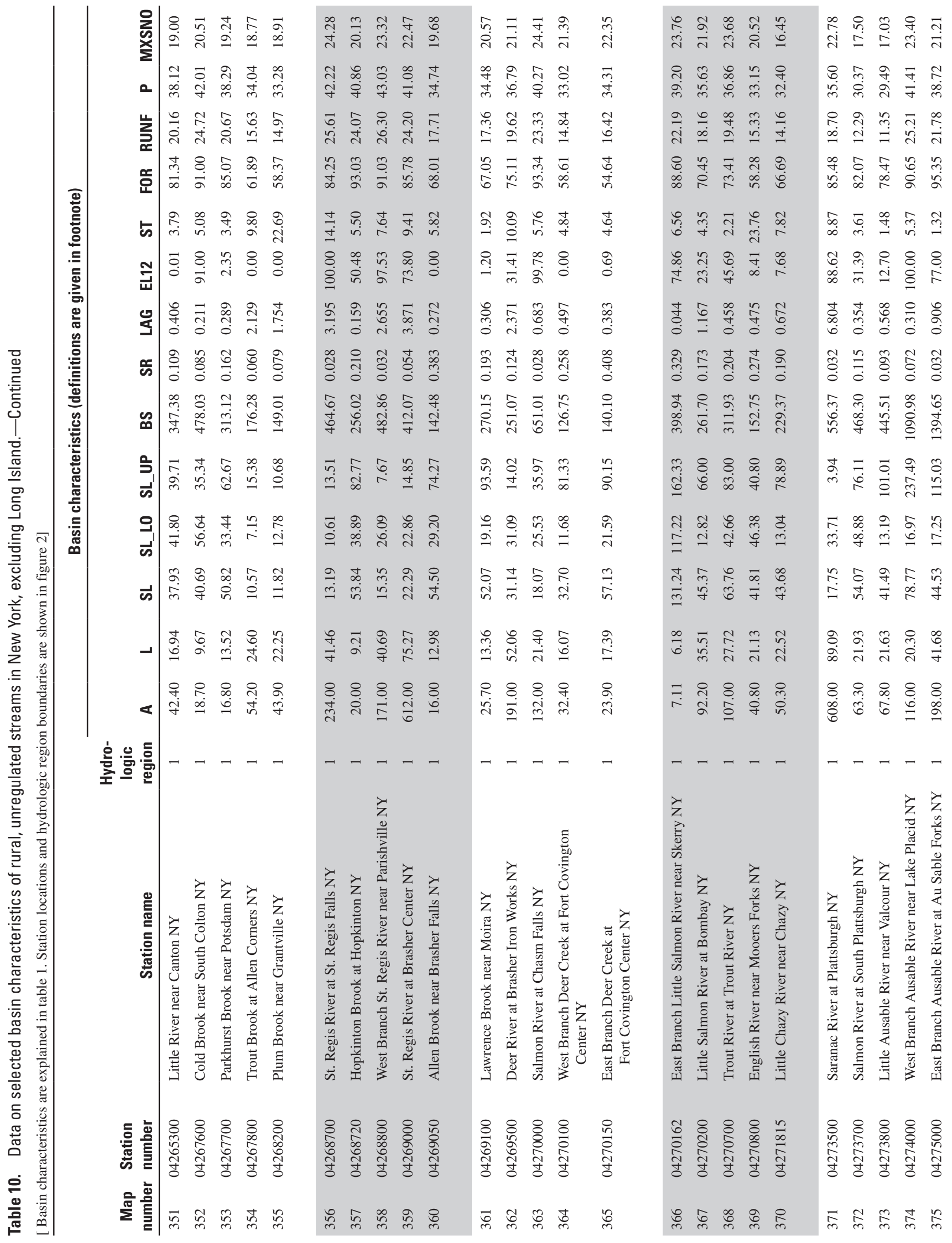




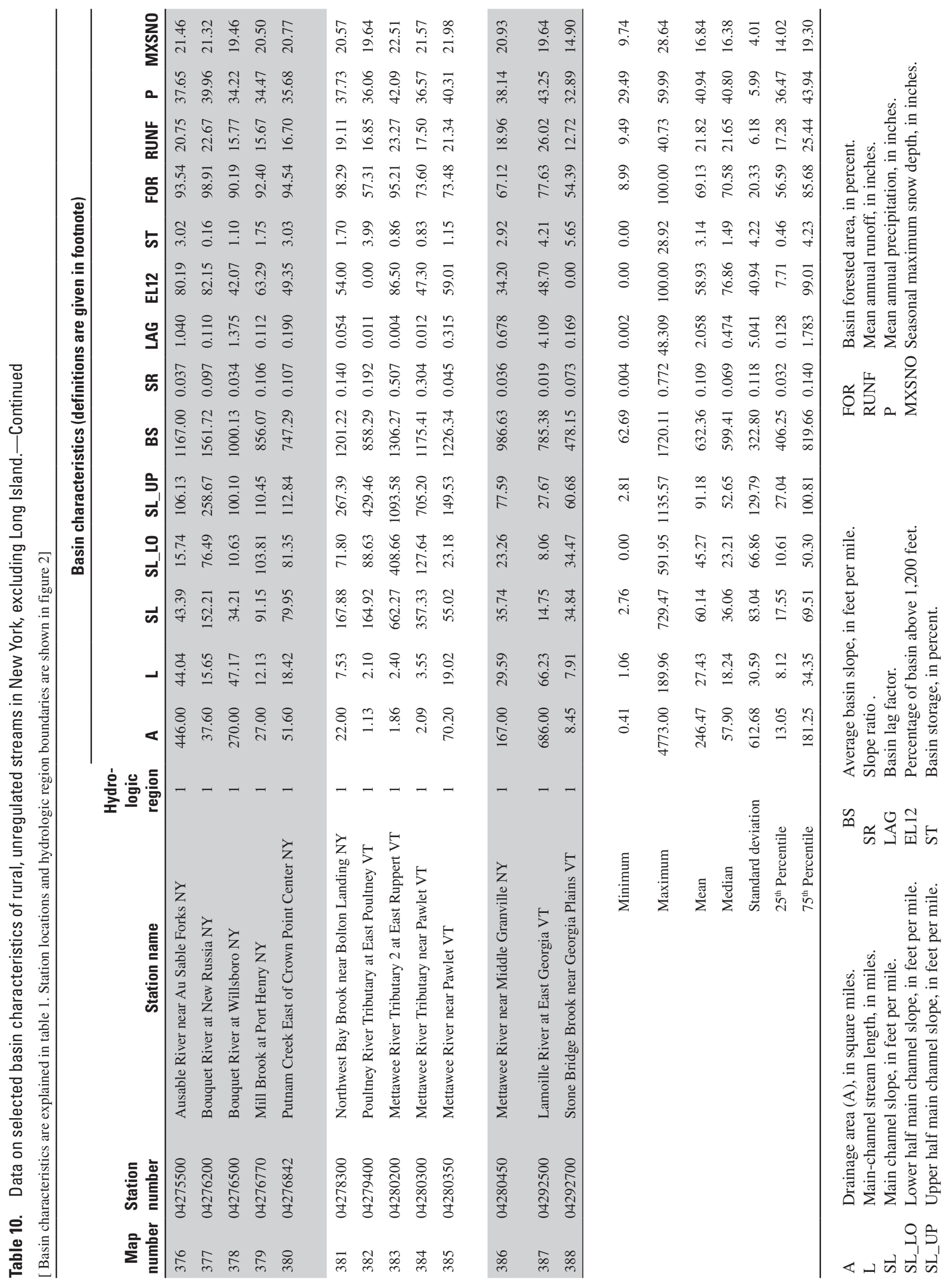




\section{Appendix 1. New York Flood-Frequency Tool}

A DVD is included with this report (in the pocket at the back of the report) that contains a customized geographic information system (GIS) tool that automates the measurement of basin characteristics and calculation of corresponding flow statistics. The application, called the New York FloodFrequency Tool, allows the user to select a point of interest on a synthetic stream network derived from a digital elevation model (DEM). The tool automatically computes the required basin characteristics and solves the regional regression equations based on the location of the site of interest. The tool produces a map for the user to review the results of the automated measurement of basin characteristics and a text file containing the calculated basin parameters and flow statistics.

The DVD also contains a spreadsheet for computing peak discharges for a gaged site, an ungaged site, or an ungaged site on a gaged stream within any of the six flood-frequency hydrologic regions developed for this report (a separate worksheet is included for each region).

The New York Flood Frequency Tool was developed with the Environmental Systems Research Institute, Inc. (ESRI) Arc/INFO Workstation version 9.1 software using the ESRI Arc Macro Language (AML) for the programming language.

Updates and additional information about the New York Flood-Frequency Tool can be downloaded from the USGS New York Water Science Center website at http://ny.water. usgs.gov/projects/floodfreq.

\section{System Requirements}

The New York Flood-Frequency Tool requires the following software:

1. ESRI ArcGIS Desktop 9.0 or higher with the Spatial Analyst extension;

2. ESRI Arc/INFO Workstation, version 9.0 or higher with the Grid module;

The New York Flood-Frequency Tool successfully runs on Microsoft Windows XP. Other operating systems have not been tested. Required disk space for computing basin characteristics throughout New York is estimated to be 3.3 gigabytes.

\section{Data Requirements}

The New York Flood-Frequency Tool functions properly by copying the entire suite of programs and supporting datasets using the naming convention provided on the DVD. The following is a summary of the directory structure and contents:

\author{
Iny_flood_freq - top level directory name \\ laml - location of AML program files, batch files, \\ shortcuts, help and readme files \\ Icomp_ny - location of the Excel spreadsheets for \\ computing discharges in each of the \\ hydrologic regions \\ linput - location for user-supplied basin outlines and \\ of auto-delineated basin outlines created by \\ the New York Flood-Frequency Tool \\ Ined - location of the National Elevation Dataset \\ (NED) 1 Arc Second raster product and \\ elevation derivatives \\ loutput - location of the output text summary files, \\ ArcPlot GRA maps, and enhanced metafile \\ (EMF) map files \\ Iprereq - location of prerequisite projection files, \\ supporting datasets, and the AFPL \\ Ghostscript utility \\ Iprocess - temporary processing folder, should be \\ empty when not in run time \\ Iraster - location of raster datasets needed for \\ generating basin characteristics.
}

The datasets included on the DVD were used to develop the equations and should be used when generating basin characteristics for the regional regression equations. To use different or updated versions of these datasets may result in computed discharges of undeterminable accuracy. More detailed information about the spatial datasets included on the DVD can be found on p. 12 under "Basin Characteristics".

\section{Installation of the New York Flood-Frequency Tool}

Once the required ESRI software is installed and the programs, datasets, and other supporting files are loaded in the appropriate directory structure, the New York FloodFrequency Tool is ready for use. Proper installation requires the following steps:

1. Copy the entire ny_flood_freq folder from the DVD to a location on a local drive (for example, C: Iny_flood_freq).

2. In the \ny_flood_freq \amls folder, right click on the "NY Flood-Frequency Tool" shortcut, and select Properties. Under the Shortcut tab, edit the path to the "Start In" to reflect the location of the amls folder in your local installation and edit the "Target" to reflect the location of the menu.bat file in your amls folder in your local installation. 
(for example Target: C: $\left.\backslash n y \_f l o o d \_f r e q \backslash a m l s \backslash m e n u . b a t\right)$ (for example Start in: $C$ : \ny_flood_freq \amls).

3. This step is dependent on your ESRI ArcGIS installation location. If the path to your ArcGIS installation is different than $C: \backslash A r c G I S \backslash$, the menu.bat file in the amls folder must be edited to reflect the correct path of your ArcGIS installation.

\section{Using the New York Flood-Frequency Tool}

The New York Flood-Frequency Tool is invoked by using the "NY Flood Frequency Tool" shortcut in the vny_flood_freqlamls folder. This shortcut can be copied and placed on the user's desktop. The tool consists of four steps or programs to assist users to derive the necessary basin characteristics for solving the flood-frequency regression equations in this report. A brief summary of each step is provided below:

1. Step one allows the user to select a single grid cell on the digital stream network called a pourpoint (based initially on a user provided latitude and longitude) for the site of interest. The user has the option to either input a pre-determined basin outline (recommended) or to autodelineate a basin outline using the DEM flow-direction derivative dataset.

2. Step two uses the basin outline provided by the user or delineated in step one to calculate non-DEM-generated basin characteristics required to solve the floodfrequency equations.

3. Step three uses the pourpoint grid cell and the basin outline from step one to calculate DEM-generated basin and main-channel characteristics required to solve the flood-frequency equations.

4. Step four computes the flood-frequency discharges for selected recurrence intervals based on the information from steps one through three.

The flowchart on page 152 shows the steps involved to use the New York Flood-Frequency Tool. There is online information to guide the user through the programs and each step has a help file. The tool is designed to be used sequentially from step one through step four without interruption. For the site of interest, the tool uses a Process ID and associated basin outline to maintain continuity between steps. Using the steps out of order could result in incorrect values. If any step does not successfully complete, it is recommended that the user start over from step one. It is the user's responsibility to verify the accuracy of datasets used as inputs and any basin-characteristic outputs created by the New York Flood-Frequency Tool before use in the regional regression equations.

\section{Limitations}

The New York Flood-Frequency Tool is provided to assist users with solving the regional regression equations. However, there will be instances, especially in low relief areas, where the tool will fail to properly model the watershed. For these cases, the user may need to use an alternate method to derive the basin characteristics from the provided datasets.

Step one provides the option of delineating a basin outline for the site of interest using the DEM derivative datasets. It is the user's responsibility to verify the accuracy of any basin outline generated using this program.

Step two computes non-DEM generated basin characteristics (for example, land-use and climate parameters) using the basin outline from step one. If the computed values are outside the limits of the data used for the study sites, the accuracy of the computed discharges may be unknown (this reasoning applies to all computed basin characteristics).

The contour interval used in step three should be set to match the contour interval displayed on the 1:24,000-scale digital raster graphics for the point of interest. For an outlet of a large watershed, a larger contour interval might be required to calculate the basin characteristics.

In some cases, the tool may fail to properly model the watershed for a site of interest. Manual derivation of basin characteristics using the spatial datasets provided on the DVD may be possible. A spreadsheet is available on the DVD to compute flood discharges.

Questions regarding the use of the New York Flood-Frequency Tool can be sent to the AskNY@usgs.gov email address.

\section{Using the New York Flood-Frequency Spreadsheet}

An Excel spreadsheet (workbook) is available on the DVD for manual computation of flood discharges at a gaged site, an ungaged site, or an ungaged site on a gaged stream. The spreadsheet is located in the comp_ny folder and is called ny_flood_freqv1.0.xls. Only cells shown with a yellow background need to be edited with the correct information. All variables being computed are defined in the report in the section "Computation of Peak Discharge." Comments are included with several cells in the worksheet to assist the user. A worksheet is provided for each of the six hydrologic regions and example data are included with each worksheet. Copies of the worksheets can be made for use with specific sites of interest.

\section{Future Updates}

Updates and additional information about the New York Flood-Frequency Tool can be downloaded from the USGS New York Water Science Center website at http://ny.water. usgs.gov/projects/floodfreq. 


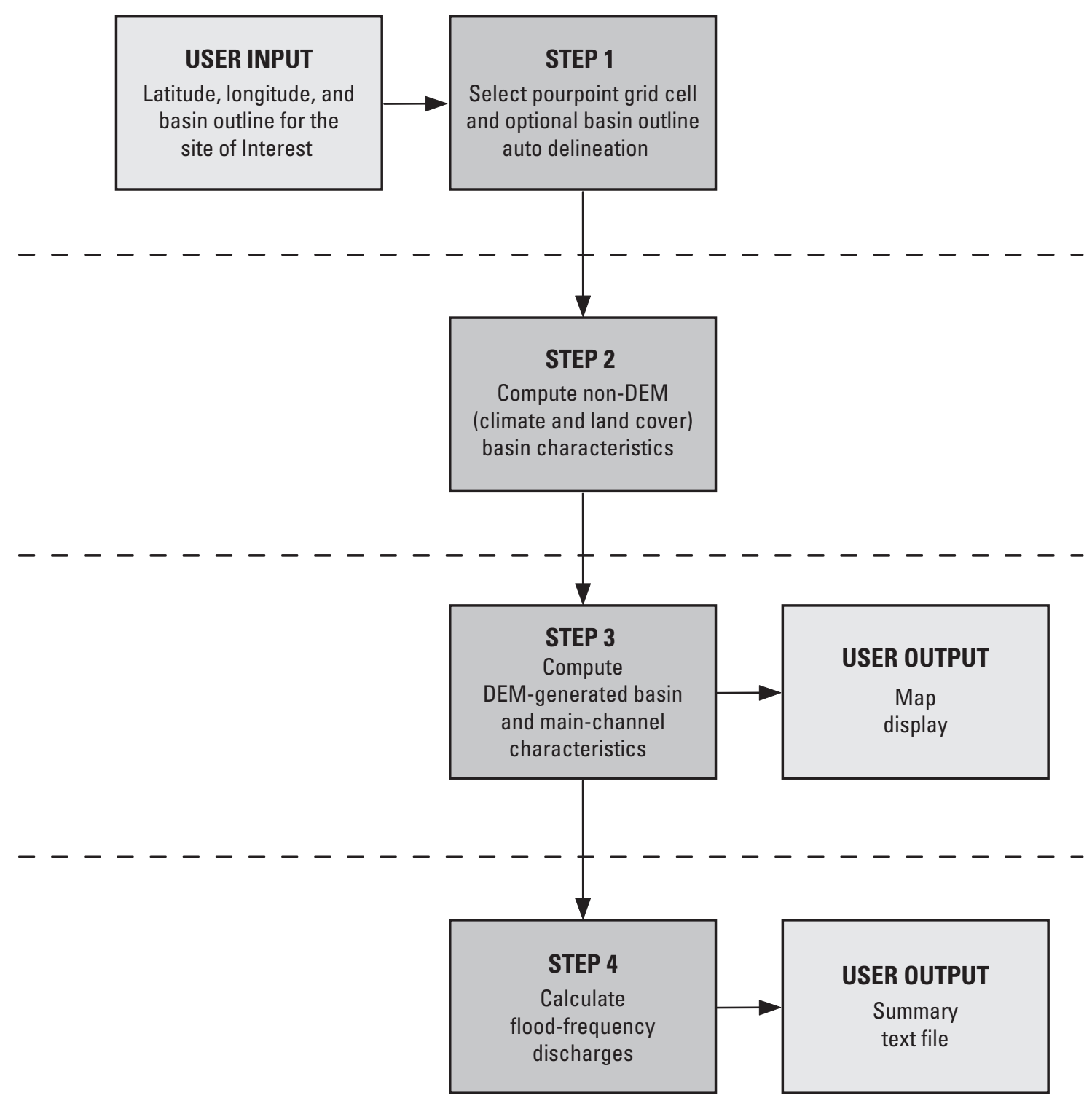


For additional information write to: New York Water Science Center

U.S. Geological Survey

425 Jordan Road

Troy, NY 12180

Information requests:

(518) 285-5602

or visit our Web site at:

http://ny.water.usgs.gov 
只

त्र

ฏุ

品

를

꼴

음

꿍

응

三

옻

\%

D

言

इ্ঠ

疍.

음.

त

응

윽

尺్ర

ज

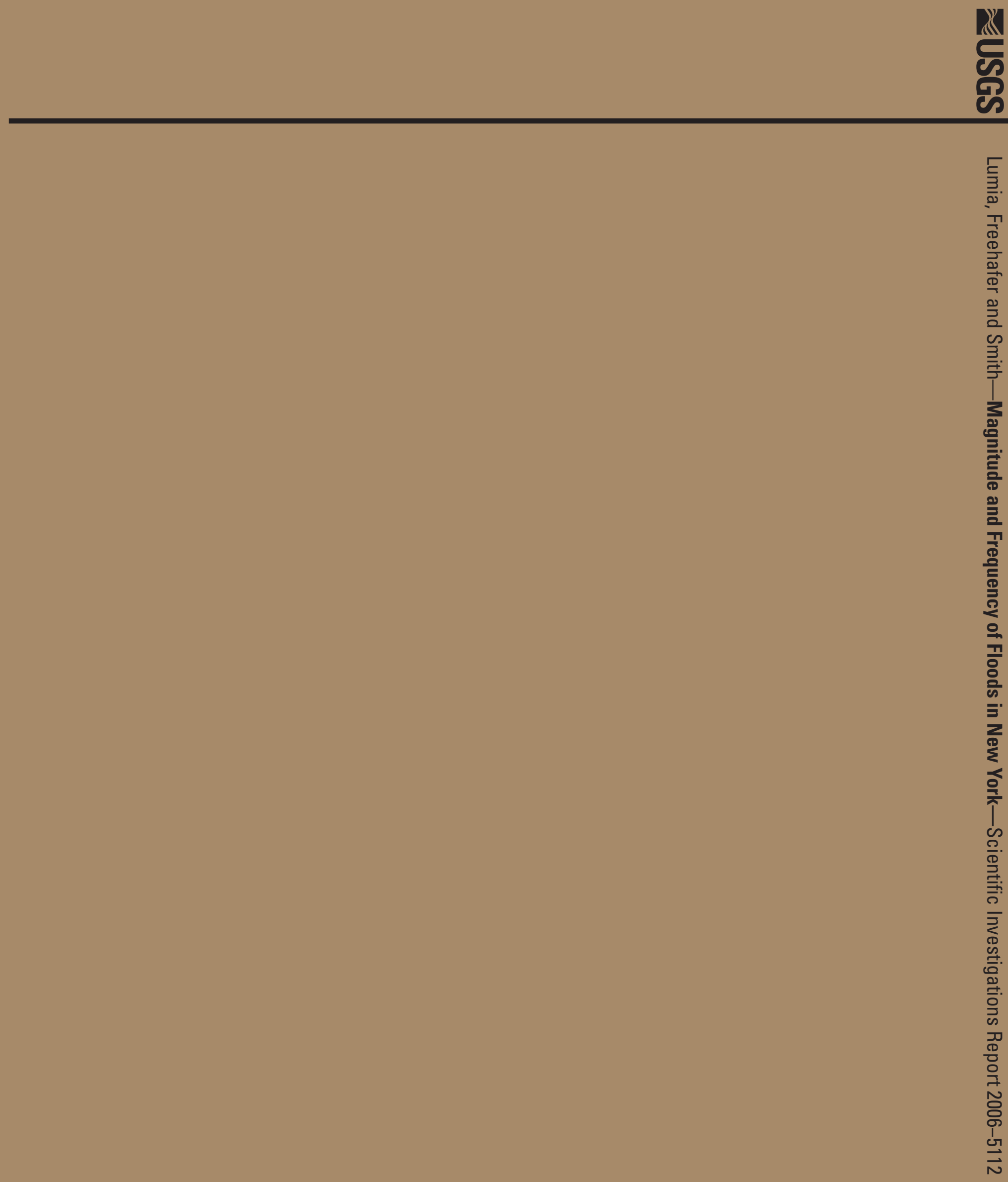

in

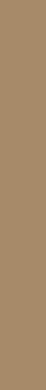

